UNIVERSIDADE DE BRASÍLIA

FACULDADE DE AGRONOMIA E MEDICINA VETERINÁRIA

PROGRAMA DE PÓS-GRADUAÇÃO EM AGRONOMIA

AVALIAÇÃO DE FUNGICIDAS NO CONTROLE DE DOENÇAS

FOLIARES, GRÃOS ARDIDOS E EFEITO NO NDVI (ÍNDICE DE VEGETAÇÃO POR DIFERENÇA NORMALIZADA) EM HÍBRIDOS DE MILHO

JULIANO DANIEL UEBEL

DISSERTAÇÃO DE MESTRADO EM AGRONOMIA

BRASÍLIA/DF

MAIO/2015 


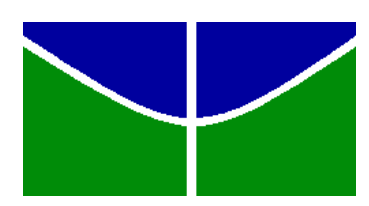

UNIVERSIDADE DE BRASÍLIA

FACULDADE DE AGRONOMIA E MEDICINA VETERINÁRIA PROGRAMA DE PÓS-GRADUAÇÃO EM AGRONOMIA

\section{AVALIAÇÃO DE FUNGICIDAS NO CONTROLE DE DOENÇAS FOLIARES, GRÃOS ARDIDOS E EFEITO NO NDVI (ÍNDICE DE VEGETAÇÃO POR DIFERENÇA NORMALIZADA) EM HÍBRIDOS DE MILHO}

JULIANO DANIEL UEBEL

ORIENTADOR: LUIZ EDUARDO BASSAY BLUM

DISSERTAÇÃO DE MESTRADO EM AGRONOMIA

PUBLICAÇÃO: 91/2015

BRASÍLIA/ DF

MAIO/2015 
UNIVERSIDADE DE BRASÍLIA

FACULDADE DE AGRONOMIA E MEDICINA VETERINÁRIA

PROGRAMA DE PÓS-GRADUAÇÃO EM AGRONOMIA

\section{AVALIAÇÃO DE FUNGICIDAS NO CONTROLE DE DOENÇAS FOLIARES, GRÃOS ARDIDOS E EFEITO NO NDVI (ÍNDICE DE VEGETAÇÃO POR DIFERENÇA NORMALIZADA) EM HÍBRIDOS DE MILHO}

JULIANO DANIEL UEBEL

DISSERTAÇÃO DE MESTRADO SUBMETIDA AO PROGRAMA DE PÓSGRADUAÇÃO EM AGRONOMIA, COMO PARTE DOS REQUISITOS NECESSÁRIOS À OBTENÇÃO DO GRAU DE MESTRE EM AGRONOMIA.

APROVADA POR:

LUIZ EDUARDO BASSAY BLUM - Professor Doutor (Universidade de Brasília)

(Orientador) CPF: 333.965.071-34 /Email: luizblum@unb.br

CARLOS HIDEMI UESUGI - Professor Doutor (Universidade de Brasília)

(Avaliador externo) CPF: 057.615.731-72 / Email: uesugich@unb.br

JOSÉ RICARDO PEIXOTO - Professor Doutor (Universidade de Brasília)

(Avaliador interno) CPF: 354.356.236-34 / Email: peixoto@unb.br

BRASÍLIA/DF, 25 de MAIO de 2015. 
FICHA CATALOGRÁFICA

UEBEL, Juliano Daniel

“AVALIAÇÃO DE FUNGICIDAS NO CONTROLE DE DOENÇAS FOLIARES, GRÃOS ARDIDOS E EFEITO NO NDVI (ÍNDICE DE VEGETAÇÃO POR DIFERENÇA NORMALIZADA) EM HÍBRIDOS DE MILHO”

Orientação: Luiz Eduardo Bassay Blum, Brasília, 2015. 119 páginas

Dissertação de Mestrado (M) - Universidade de Brasília / Faculdade de Agronomia e Medicina Veterinária, 2015.

1.Híbridos de milho 2.Fungicidas 3.Doenças foliares 4.Grãos ardidos 5.NDVI

I. Blum, L.E.B. II. Dr ${ }^{\circ}$.

\section{REFERÊNCIA BIBLIOGRÁFICA}

UEBEL, J.D. Avaliação de fungicidas no controle de doenças foliares, grãos ardidos e efeito no NDVI (Índice de Vegetação por Diferença Normalizada) em híbridos de milho. Brasília: Faculdade de Agronomia e Medicina Veterinária, Universidade de Brasília, 2015, 119 páginas. Dissertação.

\section{CESSÃO DE DIREITOS}

Nome do Autor: JULIANO DANIEL UEBEL

Título da Dissertação de Mestrado: Avaliação de fungicidas no controle de doenças foliares, grãos ardidos e efeito no NDVI (Índice de Vegetação por Diferença Normalizada) em híbridos de milho.

Grau: Mestre Ano: 2015.

É concedida à Universidade de Brasília permissão para reproduzir cópias desta dissertação de mestrado para única e exclusivamente propósitos acadêmicos e científicos. O autor reserva para si os outros direitos autorais, de publicação. Nenhuma parte desta dissertação de mestrado pode ser reproduzida sem a autorização por escrito do autor. Citações são estimuladas, desde que citada à fonte.

JULIANO DANIEL UEBEL

CPF: 000.950.770-14

Rua Appel, 367 - AP. 301 - Bairro Centro / CEP: 97.015-030 Santa Maria, RS. Brasil

(55) 3025-7169/ (61) 96453281 / email: julianouebel_1@yahoo.com.br 
Ofereço a todos os professores, pesquisadores estudantes e profissionais, que além de gostarem da área de fitossanidade, são apaixonados pela AGRONOMIA!

À toda minha FAMÍLIA, 


\section{AGRADECIMENTOS}

À Deus, pela vida e a oportunidade de estar concretizando este sonho;

À minha mãe, Noili, meus irmãos Gerson e Markiel e demais familiares, por todo amor, fé e apoio para a concretização desta etapa da minha vida;

À Dayane, pelo amor, companheirismo e todo apoio despendido durante todos esses anos, e, sua família, em especial sua mãe, Nadir e todos aqueles que também fizeram parte desta caminhada;

Ao meu orientador Professor Dr. Luiz Eduardo Bassay Blum, pela orientação, ensinamentos e amizade;

À Universidade de Brasília, em especial aos professores do Curso de Pós Graduação em Agronomia (Mestrado e Doutorado), pelos ensinamentos e amizade;

À Coordenadoria de Aperfeiçoamento de Pessoal de Nível Superior (CAPES), pelo suporte financeiro concedido;

Ao Instituto Phytus, por todo suporte e infraestrutura oferecidos para a realização deste trabalho;

À Fazenda Cereal Citrus, pela infraestrutura e local oferecidos;

Ao amigo, companheiro e colega MSc.Nédio Rodrigo Tormen, pela amizade e constante troca de experiências e ensinamentos;

Aos amigos, companheiros Paulo Xavier, Iago Xavier, Pablo Tuzi Serafini e Pedro Cadore pela ajuda na condução dos experimentos;

Ao amigo e colega Dr. Marcelo Gripa Madalosso pela troca de ideias e idealização deste trabalho;

À Dr. Caroline Gulart e Júlia Mantelli, pela ajuda com os trabalhos de laboratório;

Aos colegas Gabriel Brasileiro, Larissa G. Araújo, Janyne, Jéssika Lima e Lucas Vargas;

À todos aqueles que, direta ou indiretamente, contribuíram para a realização deste trabalho. 


\section{SUMÁRIO}

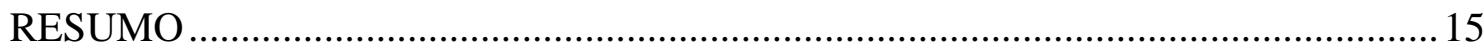

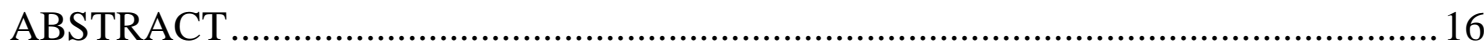

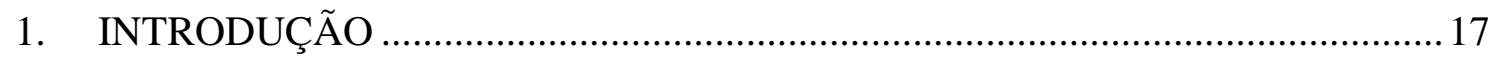

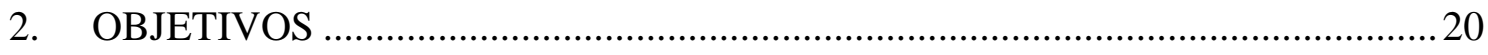

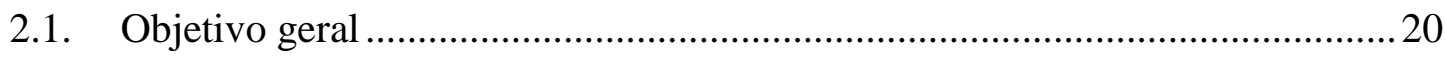

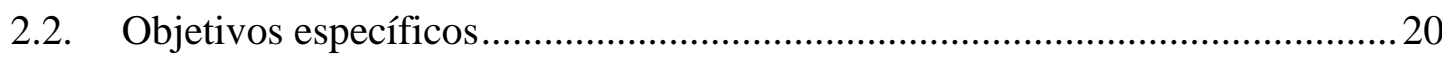

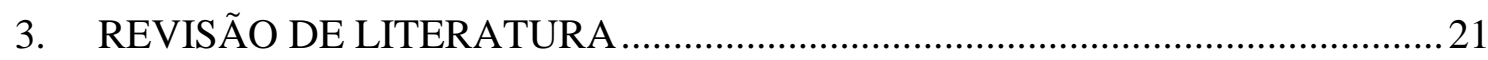

3.1. A cultura do milho........................................................................................ 21

3.2. Doenças na cultura do milho ........................................................................... 22

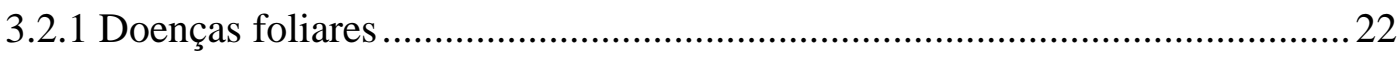

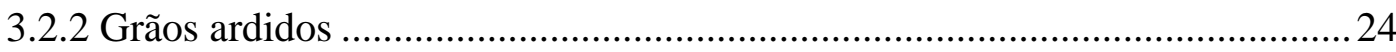

3.3. Fungicidas no controle de doenças em milho ..................................................26

3.3.1. Carboxamidas (SDHIs - inibidores do complexo II da cadeia respiratória)27

3.4. Índice de vegetação por diferença normalizada (NDVI)....................................29

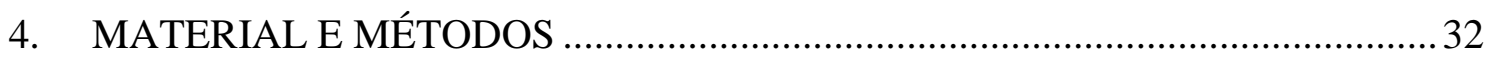

4.1. Local do experimento, semeadura e manejo da cultura ……..............................32

4.2. Delineamento experimental e tratamentos ........................................................ 33

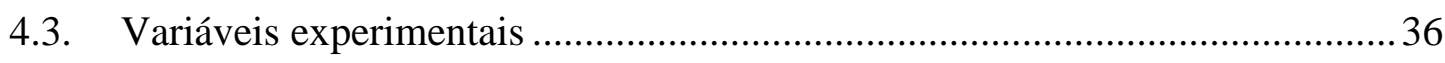

a) Severidade e Área Abaixo da Curva de Progresso da Doença (AACPD) ....36

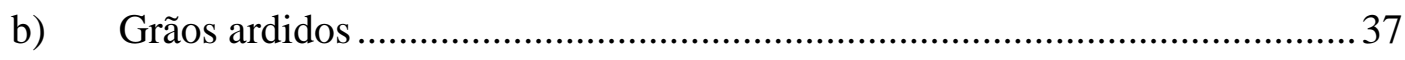

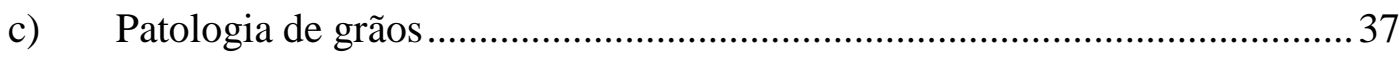

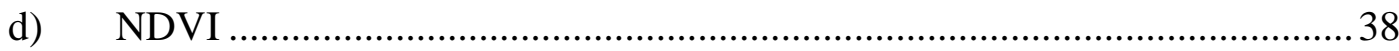

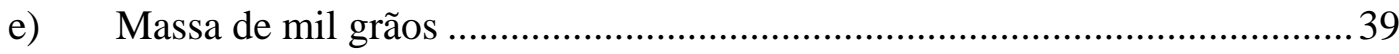

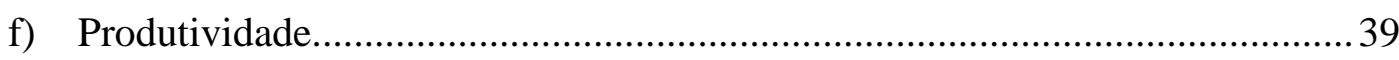




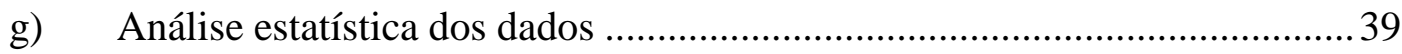

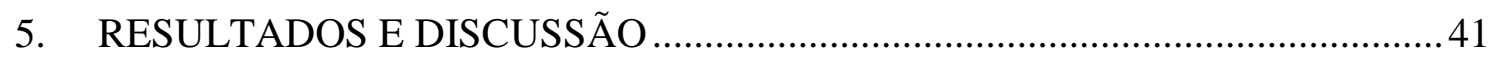

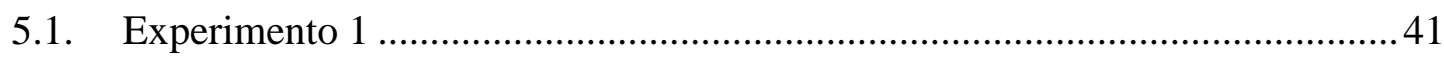

5.1.1 Área abaixo da curva de progresso da doença (AACPD) ............................ 41

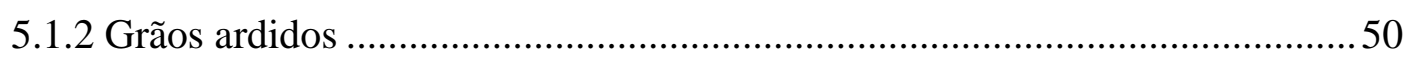

5.1.3 Patologia de grãos (Incidência de Fusarium verticillioides) ..........................52

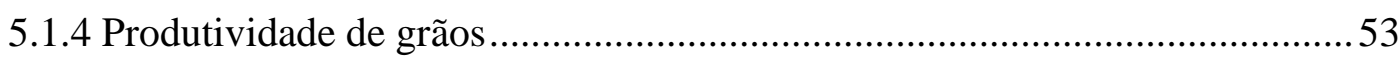

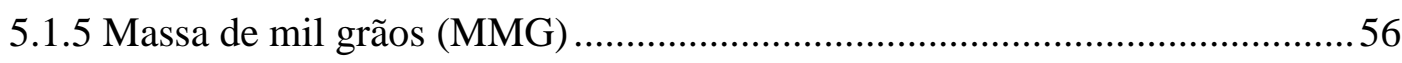

5.1.6 Índice de vegetação por diferença normalizada (NDVI) .............................58

5.1.7 Correlação entre as variáveis .................................................................6 66

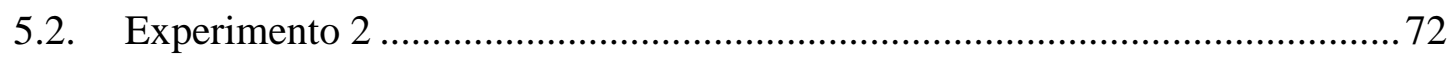

5.2.1 Área abaixo da curva de progresso da doença (AACPD) ............................. 72

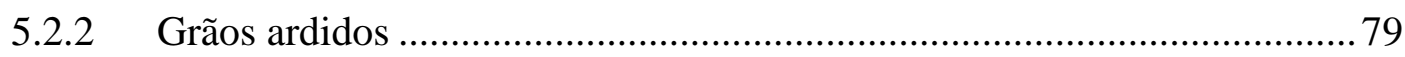

5.2.3 Patologia de grãos (Incidência de Fusarium verticillioides) ..........................80

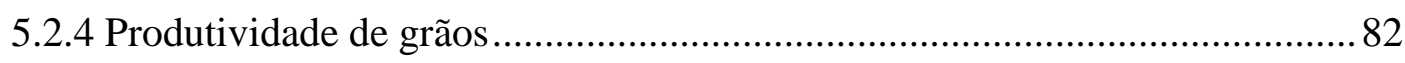

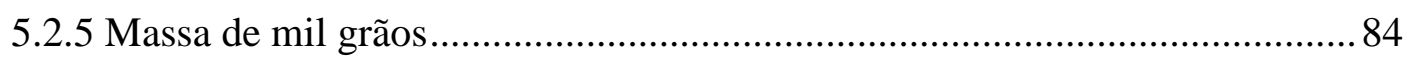

5.2.6 Índice de vegetação por diferença normalizada (NDVI) ............................. 85

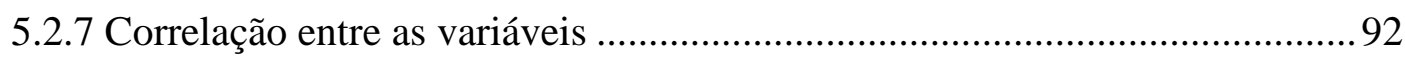

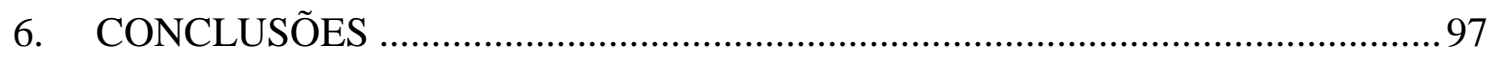

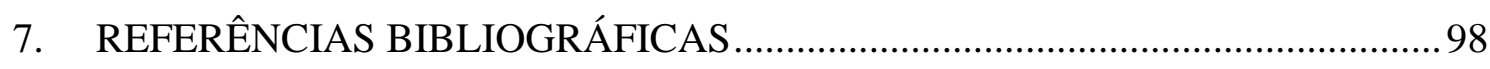

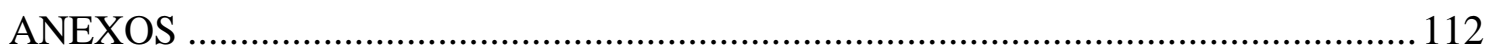

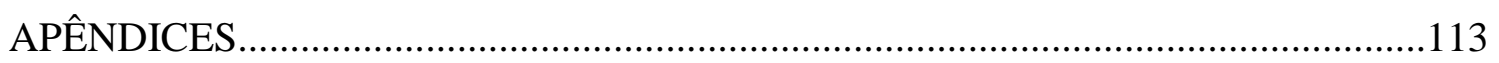




\section{LISTA DE FIGURAS}

Figura 1. Precipitação pluviométrica e temperatura média semanal (mínima e máxima) ocorridas durante a condução dos experimentos 1 e 2. Planaltina/DF, 2014 32

Figura 2. Dispersão entre os valores de Índice de vegetação por diferença normalizada (NDVI) e Área abaixo da curva de progresso das doenças (AACPD) mancha-de-turcicum (Exserohilum turcicum), ferrugem-comum (Puccinia sorghi), mancha-de-cabatiela (Kabatiella zeae) e mancha-branca (Phaeosphaeria maydis/Pantoea ananatis) no estádio R5 do híbrido de milho DKB390. *Coeficiente de correlação linear de Pearson; **Fator de determinação. Valores significativos ao nível de $1 \%$ de probabilidade $(\mathrm{p}<0,01)$.

Figura 3. Dispersão entre os valores de Índice de vegetação por diferença normalizada (NDVI) e Área abaixo da curva de progresso das doenças (AACPD) mancha-de-turcicum (Exserohilum turcicum), ferrugem-comum (Puccinia sorghi), ferrugem-polissora (Puccinia polysora), mancha-branca (Phaeosphaeria maydis/Pantoea ananatis) e cercosporiose (Cercospora zeaemaydis) no estádio R5 do híbrido de milho P30F53. *Coeficiente de correlação linear de Pearson; **Fator de determinação. Valores significativos ao nível de $1 \%$ de probabilidade $(\mathrm{p}<0,01)$

Figura 4. Dispersão entre os valores de Índice de vegetação por diferença normalizada (NDVI) e Área abaixo da curva de progresso das doenças (AACPD) ferrugem-comum (Puccinia sorghi), mancha-branca (Phaeosphaeria maydis/Pantoea ananatis) e cercosporiose (Cercospora zeae-maydis) no estádio R5 do híbrido de milho Fórmula. *Coeficiente de correlação linear de Pearson; **Fator de determinação. Valores significativos ao nível de $1 \%$ de probabilidade $(\mathrm{p}<0,01)$.

Figura 5. Dispersão entre os valores de Índice de vegetação por diferença normalizada (NDVI) e Área abaixo da curva de progresso das doenças (AACPD) mancha-de-turcicum (Exserohilum turcicum), ferrugem-comum (Puccinia sorghi), mancha-de-cabatiela (Kabatiella zeae), mancha-branca (Phaeosphaeria maydis/Pantoea ananatis) e cercosporiose (Cercospora zeaemaydis) no estádio R5 do híbrido de milho 2B587. *Coeficiente de correlação linear de Pearson;

**Fator de determinação. Valores significativos ao nível de $1 \%$ de probabilidade $(\mathrm{p}<0,01) .65$ Figura 6. Dispersão entre os valores de NDVI no estádio R5 e produtividade de grãos dos híbridos de milho DKB390, P30F53, FÓRMULA e 2B587. *Coeficiente de correlação linear de Pearson; **Fator de determinação. Valores significativos ao nível de $1 \%$ de probabilidade $(\mathrm{p}<0,01)$ 66 
Figura 7. Dispersão entre os valores de Índice de vegetação por diferença normalizada (NDVI) e Área abaixo da curva de progresso das doenças (AACPD) mancha-de-turcicum (Exserohilum turcicum), ferrugem-polissora (Puccinia polysora), mancha-de-cabatiela (Kabatiella zeae) e mancha-branca (Phaeosphaeria maydis/Pantoea ananatis) no estádio R5 do híbrido de milho DKB390. *Coeficiente de correlação linear de Pearson; **Fator de determinação. Valores significativos ao nível de $1 \%$ de probabilidade $(\mathrm{p}<0,01)$. 89

Figura 8. Dispersão entre os valores de Índice de vegetação por diferença normalizada (NDVI) e Área abaixo da curva de progresso das doenças (AACPD) mancha-de-turcicum (Exserohilum turcicum), ferrugem-comum (Puccinia sorghi), ferrugem-polissora (Puccinia polysora), mancha-branca (Phaeosphaeria maydis/Pantoea ananatis) e cercosporiose (Cercospora zeaemaydis) no estádio R5 do híbrido de milho P30F53. *Coeficiente de correlação linear de Pearson; **Fator de determinação. Valores significativos ao nível de $1 \%$ de probabilidade $(\mathrm{p}<0,01)$ 90

Figura 9. Dispersão entre os valores de Índice de vegetação por diferença normalizada (NDVI) e Área abaixo da curva de progresso das doenças (AACPD) mancha-branca (Phaeosphaeria maydis/Pantoea ananatis) e cercosporiose (Cercospora zeae-maydis) no estádio R5 do híbrido de milho Fórmula. *Coeficiente de correlação linear de Pearson; **Fator de determinação. Valores significativos ao nível de $1 \%$ de probabilidade $(\mathrm{p}<0,01)$. 90 Figura 10. Dispersão entre os valores de Índice de vegetação por diferença normalizada (NDVI) e Área abaixo da curva de progresso das doenças (AACPD) mancha-de-turcicum (Exserohilum turcicum), ferrugem-polissora (Puccinia polysora), mancha-de-cabatiela (Kabatiella zeae), mancha-branca (Phaeosphaeria maydis/Pantoea ananatis) e cercosporiose (Cercospora zeaemaydis) no estádio R5 do híbrido de milho 2B587. *Coeficiente de correlação linear de Pearson; **Fator de determinação. Valores significativos ao nível de $1 \%$ de probabilidade $(\mathrm{p}<0,01) .91$ Figura 11. Dispersão entre os valores de NDVI no estádio R5 e produtividade de grãos dos híbridos de milho DKB390, P30F53, FÓRMULA e 2B587. *Coeficiente de correlação linear de Pearson; **Fator de determinação. Valores significativos ao nível de $1 \%$ de probabilidade $(\mathrm{p}<0,01)$ 92 


\section{LISTA DE TABELAS}

Tabela 1. Características dos híbridos de milho utilizados nos experimentos 1 (semeadura em 29/11/2013) e 2 (semeadura em 22/02/2014). Planaltina/DF, 2014.

Tabela 2. Fungicidas utilizados para o controle de doenças em diferentes híbridos de milho. Planaltina/DF, 2014. 35

Tabela 3. Área abaixo da curva de progresso da cercosporiose (Cercospora zeae-maydis) (AACPC) e eficácia de controle (\%) na cultura do milho (Zea mays) em função da aplicação de diferentes tratamentos fungicidas e híbridos de milho. Planaltina/DF, 2014.

Tabela 4. Área abaixo da curva de progresso da mancha-branca (Phaeosphaeria maydis/Pantoea ananatis) (AACPMb) e eficácia de controle (\%) na cultura do milho (Zea mays) em função da aplicação de diferentes tratamentos fungicidas e híbridos de milho. Planaltina/DF, 2014. 44

Tabela 5. Área abaixo da curva de progresso da mancha-de-turcicum (Exserohilum turcicum) (AACPMt) e eficácia de controle (\%) na cultura do milho (Zea mays) em função da aplicação de diferentes tratamentos fungicidas e híbridos de milho. Planaltina/DF, 2014. 46 Tabela 6. Área abaixo da curva de progresso da ferrugem-comum (Puccinia sorghi) (AACPFc) e eficácia de controle (\%) na cultura do milho (Zea mays) em função da aplicação de diferentes tratamentos fungicidas e híbridos de milho. Planaltina/DF, 2014. 48 Tabela 7. Área abaixo da curva de progresso da ferrugem-polissora (Puccinia polysora) (AACPFp) e eficácia de controle (\%) na cultura do milho (Zea mays) em função da aplicação de diferentes tratamentos fungicidas e híbridos de milho. Planaltina/DF, 2014.

Tabela 8. Área abaixo da curva de progresso da mancha-de-cabatiela (Kabatiella zeae) (AACPMc) e eficácia de controle (\%) na cultura do milho (Zea mays) em função da aplicação de diferentes tratamentos fungicidas e híbridos de milho. Planaltina/DF, 2014. 50 Tabela 9. Incidência de grãos ardidos (\%) e eficácia de controle (\%) na cultura do milho (Zea mays) em função da aplicação de diferentes tratamentos fungicidas e híbridos de milho. Planaltina/DF, 2014. 51

Tabela 10. Incidência de Fusarium verticillioides (\%) em grãos de milho e eficácia de controle (\%) em função da aplicação de diferentes tratamentos fungicidas e híbridos de milho. Planaltina/DF, 2014. 53 
Tabela 11. Produtividade de grãos (kg.ha' $\left.{ }^{1-}\right)$ da cultura do milho (Zea mays) e incremento de produtividade (\%) em função da aplicação de diferentes tratamentos fungicidas e híbridos de milho. Planaltina/DF, 2014. 56

Tabela 12. Massa de mil grãos (g) (MMG) de milho e incremento na massa de mil grãos (\%) em função da aplicação de diferentes tratamentos fungicidas e híbridos de milho. Planaltina/DF, 2014

Tabela 13. Índice de vegetação por diferença normalizada (NDVI) da cultura do milho em diferentes estádios fenológicos em função de híbridos de milho e da aplicação de diferentes tratamentos fungicidas. Planaltina/DF, 2014.

Tabela 14. Coeficiente de correlação linear de Pearson entre as variáveis produtividade de grãos (Prod.), massa de mil grãos (MMG), área abaixo da curva de progresso das doenças ferrugemcomum (AACPFc), mancha-de-cabatiela (AACPMc), mancha-branca (AACPMb) e manchade-turcicum (AACPMt), incidência de grãos ardidos (\%), incidência de Fusarium verticillidoides em grãos (\%) e índice de vegetação por diferença normalizada (NDVI) no híbrido de milho DKB390. Planaltina/DF, 2014. 70 Tabela 15. Coeficiente de correlação linear de Pearson entre as variáveis produtividade de grãos (Prod.), massa de mil grãos (MMG), área abaixo da curva de progresso das doenças cercosporiose (AACPC), ferrugem-comum (AACPFc), ferrugem-polissora (AACPFp), mancha-branca (AACPMb) e mancha-de-turcicum (AACPMt), incidência de grãos ardidos (\%), incidência de Fusarium verticillidoides em grãos (\%) e índice de vegetação por diferença normalizada (NDVI) no híbrido de milho P30F53. Planaltina/DF, 2014. 71

Tabela 16. Coeficiente de correlação linear de Pearson entre as variáveis produtividade de grãos (Prod.), massa de mil grãos (MMG), área abaixo da curva de progresso das doenças cercosporiose (AACPC), ferrugem-comum (AACPFc) e mancha-branca (AACPMb), incidência de grãos ardidos (\%), incidência de Fusarium verticillidoides em grãos (\%) e índice de vegetação por diferença normalizada (NDVI) no híbrido de milho Fórmula. Planaltina/DF, 2014. 71

Tabela 17. Coeficiente de correlação linear de Pearson entre as variáveis produtividade de grãos (Prod.), massa de mil grãos (MMG), área abaixo da curva de progresso das doenças cercosporiose (AACPC), ferrugem-comum (AACPFc), mancha-de-cabatiela (AACPMc), mancha-branca (AACPMb) e mancha-de-turcicum (AACPMt), incidência de grãos ardidos (\%), incidência de Fusarium verticillidoides em grãos (\%) e índice de vegetação por diferença normalizada (NDVI) no híbrido de milho 2B587. Planaltina/DF, 2014. 
Tabela 18. Área abaixo da curva de progresso da cercosporiose (Cercospora zeae-maydis) (AACPC) e eficácia de controle (\%) na cultura do milho (Zea mays) em função da aplicação de diferentes tratamentos fungicidas e híbridos de milho. Planaltina/DF, 2014. 73

Tabela 19. Área abaixo da curva de progresso da mancha-branca (Phaeosphaeria maydis/Pantoea ananatis) (AACPMb) e eficácia de controle (\%) na cultura do milho (Zea mays) em função da aplicação de diferentes tratamentos fungicidas e híbridos de milho. Planaltina/DF, 2014. 74

Tabela 20. Área abaixo da curva de progresso da mancha-de-turcicum (Exserohilum turcicum) (AACPMt) e eficácia de controle (\%) na cultura do milho (Zea mays) em função da aplicação de diferentes tratamentos fungicidas e híbridos de milho. Planaltina/DF, 2014. 75 Tabela 21. Área abaixo da curva de progresso da ferrugem-comum (Puccinia sorghi) $(\mathrm{AACPFc})$ e eficácia de controle (\%) na cultura do milho (Zea mays) em função da aplicação de diferentes tratamentos fungicidas e híbridos de milho. Planaltina/DF, 2014. 76 Tabela 22. Área abaixo da curva de progresso da ferrugem-polissora (Puccinia polysora) $(\mathrm{AACPFc})$ e eficácia de controle (\%) na cultura do milho (Zea mays) em função da aplicação de diferentes tratamentos fungicidas e híbridos de milho. Planaltina/DF, 2014...... 78 Tabela 23. Área abaixo da curva de progresso da mancha-de-cabatiela (Kabatiella zeae) (AACPMc) e eficácia de controle (\%) na cultura do milho (Zea mays) em função da aplicação de diferentes tratamentos fungicidas e híbridos de milho. Planaltina/DF, 2014. 79 Tabela 24. Incidência de grãos ardidos (\%) e eficácia de controle (\%) na cultura do milho (Zea mays) em função da aplicação de diferentes tratamentos fungicidas e híbridos de milho. Planaltina/DF, 2014.

Tabela 25. Incidência de Fusarium verticillioides (\%) em grãos de milho e eficácia de controle (\%) em função da aplicação de diferentes tratamentos fungicidas e híbridos de milho. Planaltina/DF, 2014. 82

Tabela 26. Produtividade de grãos (kg.ha ${ }^{1-}$ ) da cultura do milho (Zea mays) e incremento de produtividade (\%) em função da aplicação de diferentes tratamentos fungicidas e híbridos de milho. Planaltina/DF, 2014.

Tabela 27. Massa de mil grãos (g) (MMG) de milho e incremento na massa de mil grãos (\%) em função da aplicação de diferentes tratamentos fungicidas e híbridos de milho. Planaltina/DF, 2014. 85 
Tabela 28. Índice de vegetação por diferença normalizada (NDVI) da cultura do milho em diferentes estádios fenológicos em função de híbridos de milho e da aplicação de diferentes tratamentos fungicidas. Planaltina/DF, 2014.

Tabela 29. Coeficiente de correlação linear de Pearson entre as variáveis produtividade de grãos (Prod.), massa de mil grãos (MMG), área abaixo da curva de progresso das doenças ferrugempolissora (AACPFp), mancha-de-cabatiela (AACPMc), mancha-branca (AACPMb) e manchade-turcicum (AACPMt), incidência de grãos ardidos (\%), incidência de Fusarium verticillidoides em grãos (\%) e índice de vegetação por diferença normalizada (NDVI) no híbrido de milho DKB390. Planaltina/DF, 2014.

Tabela 30. Coeficiente de correlação linear de Pearson entre as variáveis produtividade de grãos (Prod.), massa de mil grãos (MMG), área abaixo da curva de progresso das doenças cercosporiose (AACPC), ferrugem-comum (AACPFc), ferrugem-polissora (AACPFp), mancha-branca (AACPMb) e mancha-de-turcicum (AACPMt), incidência de grãos ardidos (\%), incidência de Fusarium verticillidoides em grãos (\%) e índice de vegetação por diferença normalizada (NDVI) no híbrido de milho P30F53. Planaltina/DF, 2014. 95

Tabela 31. Coeficiente de correlação linear de Pearson entre as variáveis produtividade de grãos (Prod.), massa de mil grãos (MMG), área abaixo da curva de progresso das doenças cercosporiose (AACPC) e mancha-branca (AACPMb), incidência de grãos ardidos (\%), incidência de Fusarium verticillidoides em grãos (\%) e índice de vegetação por diferença normalizada (NDVI) no híbrido de milho Fórmula. Planaltina/DF, 2014. 95

Tabela 32. Coeficiente de correlação linear de Pearson entre as variáveis produtividade de grãos (Prod.), massa de mil grãos (MMG), área abaixo da curva de progresso das doenças cercosporiose (AACPC), ferrugem-polissora (AACPFp), mancha-de-cabatiela (AACPMc), mancha-branca (AACPMb) e mancha-de-turcicum (AACPMt), incidência de grãos ardidos (\%), incidência de Fusarium verticillidoides em grãos (\%) e índice de vegetação por diferença normalizada (NDVI) no híbrido de milho 2B587. Planaltina/DF, 2014. 96 


\section{RESUMO}

A cultura do milho no Brasil está sujeita a diversos problemas, sendo que as doenças têm merecido grande atenção na atualidade, principalmente pelo alto potencial de perdas que estas geram. Vários são os patógenos com potencial de risco à cultura do milho, dentre eles Cercospora zeae-maydis (cercosporiose), Phaeosphaeria maydis/Pantoea ananatis (manchabranca), Exserohilum turcicum (mancha-de-turcicum), Puccinia sorghi (ferrugem-comum), Puccinia polysora (ferrugem-polissora), Kabatiella zeae (mancha-de-cabatiela) e fungos causadores de grãos ardidos como Fusarium verticillioides. O uso de sensores remotos que fornecem leituras de NDVI (Índice de Vegetação por Diferença Normalizada) podem contribuir para melhor avaliação do estado fitossanitário da cultura do milho e também prover meios para estimativa do potencial produtivo da cultura. Visando avaliar o efeito de fungicidas no controle de doenças foliares e grãos ardidos, e, a correlação do NDVI com parâmetros agronômicos e fitopatológicos na cultura do milho, foram realizados dois experimentos na safra agrícola 2013/14. Foi utilizado o delineamento experimental de blocos completos ao acaso, com parcelas subdivididas e quatro repetições, em arranjo fatorial (4x6). $\mathrm{O}$ fator $\mathrm{A}$ (híbridos) constituiu as parcelas principais e o fator $\mathrm{B}$ (fungicidas) constituiu-se nas subparcelas. $\mathrm{O}$ fator $\mathrm{A}$ foi composto pelos híbridos de milho DKB390, P30F53, Fórmula e 2B587, e, o fator B composto pela Testemunha (sem aplicação), Fluxapiroxade + Piraclostrobina $\left(50,1+99,9\right.$ g.L - $\left.^{-1}\right)+$ adjuvante, Benzovindiflupir + Azoxistrobina $\left(49,5+99\right.$ g.L - $\left.^{-1}\right)+$ adjuvante, Bixafen + Trifloxistrobina + Protioconazol + Adjuvante $\left(50+60+70\right.$ g.L L $\left.^{-1}\right)$, Trifloxistrobina + Protioconazol + Adjuvante $\left(75+87,5\right.$ g.L $\left.\mathrm{L}^{-1}\right)$ e Controle Total. Foram realizadas três aplicações dos tratamentos fungicidas, com exceção a Testemunha, sem aplicação e do Controle Total, no qual foram realizadas oito aplicações de Fluxapiroxade + Piraclostrobina $\left(50,1+99,9\right.$ g. $\left.\mathrm{L}^{-1}\right)+$ adjuvante, com intervalos de dez dias. As variáveis estudadas foram área abaixo da curva de progresso da doença (AACPD), grãos ardidos, incidência de $F$. verticillioides em grãos de milho, produtividade, massa de mil grãos e NDVI. Os fungicidas foram eficientes no controle da maioria das doenças avaliadas nos diferentes híbridos de milho. Houveram diferenças quanto ao espectro de doenças controladas pelos fungicidas estudados. Todos os tratamentos fungicidas contribuíram para redução de grãos ardidos e incidência de $F$. verticillioides em grãos de milho. Todos os fungicidas proporcionaram incrementos na produtividade e massa de mil grãos. O uso de NDVI na cultura do milho visando avaliação do estado sanitário em relação a doenças mostrou-se efetivo na diferenciação entre os tratamentos mais doentes e mais sadios. O NDVI também mostrou ser um importante parâmetro para se estimar o potencial produtivo da cultura do milho.

Palavras-chave: híbridos de milho, fungicidas, doenças foliares, grãos ardidos, NDVI. 


\begin{abstract}
The maize crop in Brazil is subject to various phytosanitary problems and diseases have received great attention at present, mainly because the high potential losses that these generate. Several are the pathogens with potential risk to the corn crop, including Cercospora zeaemaydis (gray leaf spot), Phaeosphaeria maydis/Pantoea ananatis (Phaeosphaeria leaf spot), Exserohilum turcicum (northern corn leaf blight), Puccinia sorghi (common rust), Puccinia polysora (southern rust), Kabatiella zeae (eyespot or brown-spot) and fungi that cause rotten kernels such as Fusarium verticillioides. The use of remote sensors that provide NDVI (Normalized Difference Vegetation Index) readings can contribute to better evaluation of the plant health of maize and also provide a means to estimate the potential corn production. Aiming to evaluate the effect of fungicides in the control of foliar corn diseases and rot kernels, and the correlation of NDVI with agronomic and phytopathological parameters in maize, two experiments were conducted during the 2013/14 growing season. It was used the randomized complete block design with split-plots, four replications and factorial scheme (4x6). The factor A (hybrids) constituted the main plots and the factor B (fungicides) constituted the subplots. The factor A was composed by corn hybrids DKB390, P30F53, Fórmula and 2B587, and factor B composed of the Untreated control, Fluxapyroxad + Pyraclostrobin $(50.1+99.9$ g.L -1 $)+$ adjuvant, Benzovindiflupyr + Azoxystrobin $\left(49.5+99\right.$ g. L $\left.-^{1}\right)+$ adjuvant, Bixafen + Trifloxystrobin + Prothioconazole + Adjuvant $\left(50+60+70\right.$ g. L - $\left.{ }^{1}\right)$, Trifloxystrobin + Prothioconazole + Adjuvant $\left(75+87.5\right.$ g.L - $\left.{ }^{1}\right)$ and the Total Control. Except the Untreated control and the Total Control (with eight applications of Fluxapyroxad + Pyraclostrobin (50.1 +99.9 g.L - $\left.{ }^{1}\right)+$ adjuvant, with ten days frequency), it was made three applications of fungicide treatments in the other treatments. The variables assessed were area under disease progress curve (AUDPC), damaged kernels, incidence of $F$. verticillioides in corn kernels, grain yield, thousand grain weight and NDVI. The fungicides have been effective in controlling most diseases evaluated in different corn hybrids. There are differences in the spectrum of diseases controlled by fungicides studied. All fungicide treatments contributed to reduction of damaged kernels and incidence of $F$. verticillioides in corn kernels. All fungicides increased corn yield and thousand grain weight. The use of NDVI in corn aiming to evaluate the phytosanitary status was effective in differentiating the diseased and healthier treatments. The NDVI also proved to be an important parameter to estimate the corn yield potential.
\end{abstract}

Keywords: corn hybrids, fungicides, foliar diseases, damaged kernels, NDVI. 


\section{INTRODUÇÃO}

O milho (Zea mays L.) é uma das mais importantes culturas para o agronegócio brasileiro e mundial, uma vez que a cultura tem seus grãos utilizados seja na alimentação humana e animal, mas também na produção de etanol, principalmente nos Estados Unidos.

O Brasil é um dos maiores produtores mundiais de milho, ocupando hoje a terceira posição no ranking dos países produtores do cereal. Na safra 2013/14, o país produziu 80 milhões de toneladas do grão, atrás apenas dos Estados Unidos e China com 351 e 218 milhões de toneladas, respectivamente (USDA, 2015).

Atualmente, no Brasil, a cultura é cultivada em 15 milhões de hectares e com a média de produtividade superando 5 t/ha $(\mathrm{CONAB}, 2015)$. Em mais de duas décadas atrás, no ano de 1990, a área cultivada era aproximadamente 11,4 milhões de hectares e a produtividade média brasileira inferior a 2 t/ha, com uma produção total de 21,35 milhões de toneladas.

O nível tecnológico empregado ao cultivo do milho no país avançou muito se compararmos os números recentes obtidos com a cultura em relação àqueles obtidos no passado. Muito desse avanço se deve ao melhoramento genético, aumentando o potencial produtivo dos híbridos atualmente cultivados. Ainda, muito se melhorou em termos de práticas culturais, irrigação e uso de insumos para se buscar o máximo do potencial produtivo dos híbridos de milho atuais. Ao compararmos a média de produtividade brasileira com o potencial produtivo atual desses híbridos, veremos que muito se tem a alcançar para atingirmos tal montante. Claro que uma das causas da média ainda ser baixa no país é a heterogeneidade entre as regiões produtoras do Brasil. Como na região nordeste boa parte da produção é de subsistência, o nível tecnológico empregado é baixo se compararmos com as regiões centrooeste, sul e sudeste. Mesmo assim, ainda tem muito em avançar em termos de produtividade da cultura no país.

Um dos problemas enfrentados com aumento de área cultivada e principalmente por termos duas safras com a cultura no país, são de ordem fitossanitária, sejam eles com plantas daninhas, pragas ou doenças, mas principalmente pelas duas últimas.

O fato de termos o cultivo em praticamente durante todo o ano e em todo território nacional, em um país tropical como o Brasil, tornam-se inevitáveis problemas com doenças atingindo a cultura de norte a sul do país. Áreas de segunda safra ("safrinha”) aliadas à irrigação, ao sistema de "plantio direto" e sucessão de culturas contribuem para a manutenção e sobrevivência de diversos patógenos no campo durante o ano inteiro. Mesmo que o 
melhoramento genético tenha avançado muito com os híbridos de milho atuais, a resistência genética às doenças ainda não consegue tornar tais híbridos totalmente resistentes aos principais patógenos que ocorrem nas lavouras atualmente.

Várias doenças afetam a cultura do milho no Brasil, sejam elas radiculares, de colmo, foliares, de espiga e/ou grãos. São exemplos a cercosporiose (Cercospora zeae-maydis), mancha-branca ou feosféria (Phaeosphaeria maydis/Pantoea ananatis), mancha-de-turcicum (Exserohilum turcicum), as ferrugens [comum (Puccinia sorghi), polissora (Puccinia polysora) e tropical (Physopella zeae)], mancha-de-diplodia (Stenocarpella macrospora), antracnose (Colletotrichum graminicola), fusarioses (Fusarium spp.), entre outras (REIS; CASA; BRESOLIN, 2004). Da raiz ao grão que é formado são alvos dos mais diversos patógenos. Merecem grande importância também aqueles patógenos que infectam grãos e que produzem metabólitos secundários como as micotoxinas, que são tóxicos aos humanos e principalmente animais.

A alta incidência e severidade de determinadas doenças na cultura do milho tem provocado quedas significativas de produtividade, principalmente, quando medidas de controle não são adotadas. No caso de doenças foliares, os danos são decorrentes da baixa eficiência e/ou destruição dos tecidos fotossintéticos, e que, com o aumento da área e número de lesões, podem determinar a necrose da superfície foliar, além de acelerar a senescência foliar das plantas de milho.

Dentro de um manejo integrado de doenças, além de todas as práticas que visam a prevenção, o uso de produtos químicos como fungicidas tornaram-se uma das ferramentas de grande importância no manejo de doenças na cultura do milho. São muitos os produtos registrados para o controle de enfermidades na cultura do milho no Brasil. No entanto, é importante se fazer o bom uso dessa ferramenta, já que o uso indiscriminado e sem critérios técnicos importantes, como escolha correta do produto, momento e dose de aplicação, podem levar a problemas de falha de controle e favorecer a resistência de patógenos aos produtos químicos. Dentro dessa ótica, é imprescindível o uso de diferentes grupos químicos visando evitar o surgimento de resistência por partes dos microorganismos fitopatogênicos.

Os principais grupos químicos de fungicidas utilizados no controle de doenças na cultura do milho no Brasil são de grupos como triazóis, estrobilurinas e etilenobisditiocarbamatos. Este último, de uso antigo na agricultura mundial, por se tratar de fungicidas de ação multisítio na célula do fungo, vem recebendo nova atenção, não só para a cultura do milho, mas para várias outras culturas, devido aos casos de resistência de patógenos 
aos fungicidas. Mais recentemente, vem sendo testados novos produtos de um grupo químico ainda pouco explorado na cultura do milho que são as carboxamidas. Esse grupo torna-se uma importante ferramenta a somar-se com os demais grupos já existentes no mercado para a cultura do milho. Logo, é de suma importância testá-lo para melhor explorá-lo no manejo de doenças na cultura desse cereal tão importante ao agronegócio brasileiro e mundial.

A cultura do milho está sujeita as mais diversas desordens, sejam de origem abiótica ou biótica. Todos eles, de uma forma ou outra, acabam refletindo fisiologicamente e/ou morfologicamente. Por isso, torna-se muito importante a correta diagnose do agente causador de qualquer dano à cultura no campo. Visando melhor detectar o real estado sanitário da cultura do milho no campo, o uso de ferramentas tecnológicas como sensores remotos podem ajudar a detectar no campo o real estado morfológico e fisiológico da cultura. Nesse sentido, o estudo do NDVI, Índice de Vegetação por Diferença Normalizada (Normalized Difference Vegetation Index), fornece informações que rementem ao estado nutricional e/ou sanitário da planta de milho. Através do uso do equipamento GreenSeeker ${ }^{\circledR}$ Handheld Crop Sensor, tem-se informações espectrais (leitura de reflectância no vermelho e infravermelho próximo) da cultura, o NDVI. Ou seja, informações do quanto "mais verde" ou não a planta se encontra, fornecendo assim informações adicionais àquelas obtidas em avaliações de incidência e severidade das doenças que estão ou não ocorrendo no campo.

O estudo da correlação das leituras de NDVI com parâmetros agronômicos (produtividade, massa de grãos, entre outros) e fitopatológicos (incidência e severidade de doenças, AACPD, patologia de sementes, grãos ardidos, etc.) visam melhor avaliar o estado sanitário da cultura do milho e estimar o potencial produtivo da cultura

Contudo, tendo em vista o potencial de novos grupos químicos no controle de doenças na cultura do milho e a necessidade de novas moléculas fungicidas para se somar as já existentes, visando a melhora do controle químico e a busca pelo máximo do potencial produtivo da cultura do milho, o objetivo deste trabalho é estudar o efeito de fungicidas no manejo de doenças foliares e grãos ardidos na cultura do milho, e, ainda, o potencial do uso de NDVI em avaliações do estado sanitário da cultura e sua correlação com parâmetros agronômicos e fitopatológicos. 


\section{OBJETIVOS}

\subsection{Objetivo geral}

Avaliar o efeito de fungicidas no controle de doenças foliares e grãos ardidos, e, a correlação do NDVI com parâmetros agronômicos e fitopatológicos na cultura do milho.

\subsection{Objetivos específicos}

1. Avaliar o efeito de fungicidas no controle de doenças foliares na cultura do milho.

2. Avaliar o efeito de fungicidas na incidência de patógenos em grãos de milho e incidência de grãos ardidos.

3. Avaliar a produtividade de grãos de milho pelo uso de fungicidas, assim como seu reflexo na massa de mil grãos.

4. Avaliar o parâmetro Índice de Vegetação por Diferença Normalizada (NDVI) na cultura do milho na ocorrência simultaneamente de diversos patossistemas.

5. Estudar a correlação do NDVI com variáveis fitopatológicas e agronômicas (área abaixo da curva de progresso das doenças, grãos ardidos, incidência de Fusarium verticillioides em grãos, produtividade e massa de mil grãos). 


\section{REVISÃO DE LITERATURA}

\subsection{A cultura do milho}

O cultivo do milho (Zea mays L.) é disseminado em quase todos os continentes, com uma área de aproximadamente 180 milhões de hectares e produção no montante aproximado de 989 milhões de toneladas (USDA, 2015). Trata-se de um cereal de notável importância mundial devido aos mais variados usos que faz de sua planta e seus grãos. É uma das principais fontes energéticas na alimentação humana e animal, além também da crescente importância como matéria prima para a produção de etanol.

É uma cultura de grande importância social e econômica, pois além de gerar empregos no setor primário, a cultura é matéria-prima para impulsionar diversos complexos agroindustriais (FANCELLI; DOURADO NETO, 2000).

O Brasil produz atualmente 80 milhões de toneladas de grãos do cereal sendo considerado o terceiro maior produtor mundial, valores esses inferiores apenas aqueles produzidos por Estados Unidos, 351 milhões, e China com 218 milhões de toneladas métricas (USDA, 2015).

Em uma área de 15,8 milhões de hectares, de norte a sul do país, 39,2\% são cultivados na região Centro-Oeste, $25,3 \%$ no Sul, $18,4 \%$ no Nordeste, $13,3 \%$ no Sudeste e o restante, $3,8 \%$, na região Nordeste do Brasil. Existe uma grande diferença em termos de produtividade quando comparamos essas regiões, tendo o Sul uma média de 6,1 toneladas por hectare, o Centro-Oeste 5,6 ton.ha ${ }^{-1}$, o Sudeste 5,1 ton.ha ${ }^{-1}$, o Norte 3,3 ton.ha ${ }^{-1}$ e o Nordeste com 2,6 ton.ha ${ }^{-1}$ (CONAB, 2015). Diferenças essas são dadas principalmente por questões climáticas distintas entre as mais diversas regiões do país e também pelo nível de tecnologia empregado no sistema de produção da cultura.

Apesar dos avanços tecnológicos com o cultivo do milho no país, a produtividade média obtida ainda é aquém do real potencial de produtividade que os híbridos atuais possuem. Segundo Reis et al. (2004), os principais fatores de produção da cultura do milho podem ser resumidos como a fertilidade do solo, disponibilidade hídrica, controle da erosão, população de plantas, doenças, plantas daninhas, pragas, época de semeadura, cultivar e rotação de culturas. Ultimamente, as doenças têm merecido grande destaque já que estão dificultando a obtenção de maiores produtividades com a cultura no Brasil. 


\subsection{Doenças na cultura do milho}

O nível tecnológico com a cultura tem aumentado muito no país, no entanto, sistema de plantio direto, aliado às áreas irrigadas e, associadas aos plantios de segunda safra (safrinha), predispõem a cultura a alguns fatores que colocam em risco a produtividade da lavoura, principalmente com o aumento das doenças fúngicas, por proporcionarem maior sobrevivência dos patógenos no campo e permanência de inóculo viável entre as safras.

Também, conforme Fancelli (2001), dentre os fatores responsáveis por aumentar a intensidade das doenças no campo, está o aumento de inóculo, proporcionado pela prática do plantio direto, sucessão de cultivos, manutenção da umidade com o uso de sistemas de irrigação, expansão da fronteira agrícola e aumento do número de cultivares comerciais com diferentes níveis de resistência às doenças.

Segundo Agrios (1997), para ocorrer a doença é necessário a interação entre os três componentes do patossistema, que são o hospedeiro, o patógeno e o ambiente que envolve o hospedeiro e o patógeno.

Ainda, de acordo com Pinto (2004), a maiorias das doenças do milho são ocasionadas por fungos, e que, devido à grande diversidade de épocas de semeadura nas nas diversas regiões produtoras, com a cultura do milho permanecendo no campo praticamente o ano todo, acarretam um desenvolvimento permanente de patógenos. Assim, as áreas onde a cultura está em estádio de desenvolvimento avançado serve como fonte de inóculo para áreas onde a cultura se encontra em estádios de desenvolvimento mais iniciais (PAIVA et al., 1991). Segundo Reis e Casa (1996), pelo menos vinte patógenos podem causar prejuízos significativos na cultura do milho.

\subsubsection{Doenças foliares}

As principais doenças foliares predominantes na cultura do milho nas regiões Sul, Sudeste e Centro-Oeste do Brasil são mancha-branca (Phaeosphaeria maydis/Pantoea ananatis), ferrugem-comum (Puccinia sorghi), ferrugem-polissora (Puccinia polysora), ferrugem-branca ou tropical (Physopella zeae), mancha-por-cercospora (Cercospora zeaemaydis), mancha-por-diplodia (Stenocarpella macrospora), mancha-por-turcicum (Exserohilum turcicum), mancha-por-bipolaris (Bipolaris maydis e Bipolaris zeicola) e antracnose-foliar (Colletotrichum graminicola) (PINTO et al., 2008). Ainda, segundo Camochena et al. (2007), a mancha-ocular (Kabatiella zeae) tem assumido grande importância nos últimos anos, sendo detectada em mais de 30 genótipos de milho na região sudoeste do 
Paraná, com severidades variando entre 7 e 17\%. A importância destes patossistemas varia de ano a ano e de uma região para outra, em função do nível de suscetibilidade das cultivares, do sistema de plantio utilizado e das condições climáticas no período (EMBRAPA, 2009).

As manchas foliares tem seus danos decorrentes do mau funcionamento e da destruição dos tecidos fotossintéticos devido ao aumento do número e da área de lesões que podem determinar a necrose de toda a folha. A necrose e a morte prematura das folhas limita a interceptação da radiação solar e translocação de fotossintatos ao desenvolvimento de grãos (REIS; CASA; BRESOLIN, 2004). De acordo com Fancelli (1988), a destruição de 25\% da área foliar da planta de milho em sua porção terminal, próximo ao florescimento, pode reduzir em 32\% a produção de grãos. Ainda, segundo Pataky (1992), a folha da espiga e as folhas imediatamente acima e abaixo da espiga podem representar 33 a $40 \%$ da área total da planta. Também, segundo Fischer e Palmer (1984), a redução de metade da radiação incidente 15 dias antes e 15 dias após o florescimento pode levar a uma redução de 40 a $50 \%$ no rendimento de grãos. Ainda, segundo Blum et al. (2003) a desfolha pode também afetar a incidência e a severidade de podridões do colmo em milho.

A mancha foliar de cercospora (Cercospora zeae-maydis) se manifestou severamente em muitos híbridos altamente produtivos nas safras de 2000 e 2001, e, desde então, figura-se como uma das doenças mais importantes da cultura do milho na atualidade (PEREIRA; CARVALHO; CAMARGO, 2005). Segundo Ward et al. (1994) a cercosporiose pode levar a reduções de 20 a $60 \%$ na produção de grãos.

A mancha foliar causada pelo fungo Phaeosphaeria maydis e pela bactéria Pantoea ananatis, conhecida por mancha-branca ou mancha-de-feosféria, não chegava a causar danos à cultura do milho no passado, e, geralmente ocorria no final do ciclo das plantas (FANTIN; DUARTE, 2009). Ainda, para estes mesmos autores, a doença adquiriu maior importância a partir do final da década de 80 e, atualmente, sua distribuição é generalizada pelas áreas de produção de milho no Brasil podendo causar grandes reduções de produtividade.

Quanto à mancha-de-turcicum ou queima-de-turcicum, cujo agente causal é o fungo Exserohilum turcicum, Perkins e Pedersen (1987) relataram nos Estados Unidos, redução de $18 \%$ no rendimento de grãos em híbridos com diferentes genes de resistência, e, inoculações em cinco estádios de crescimento. Já Shurtleff (1973), verificou danos de até 50\% quando a doença se estabelecer antes do pendoamento. Levando-se em consideração a presença de inóculo na área, híbrido suscetível, plantas em estádio vegetativo e condições climáticas 
favoráveis, tem-se a possibilidade de uma epidemia e consequentemente queda na produção de grãos (REIS; CASA; BRESOLIN, 2004).

Dentre as ferrugens, fungos biotróficos, que ocorrem na cultura do milho as duas mais comuns são a ferrugem-comum e a ferrugem-polissora. Essa última é a mais agressiva e destrutiva, ocorrendo preferencialmente nas regiões Centro-Oeste e Sudeste do Brasil, enquanto a outra é mais comum, porém menos severa e ocorre com mais comumente na região Sul (REIS; CASA; BRESOLIN, 2004; PEREIRA; CARVALHO; CAMARGO, 2005).

Mais recentemente detectada no Brasil, e que, segundo Camochena et al. (2007) tem assumido maior importância, é a mancha-ocular ou mancha-de-cabatiela (Kabatiella zeae), que, na região Sudoeste do Paraná foi detectada em mais de 30 genótipos de milho e severidades que variaram entre 7 e 17\%. De acordo com Santos et al. (2007) a mancha-de-cabatiela foi diagnosticada em 2004 em Santa Catarina e no Paraná. Ainda, conforme Camochena et al. (2008), apesar de estar ganhando maior importância no país, ainda pouco se sabe sobre Kabatiella zeae no Brasil.

\subsubsection{Grãos ardidos}

Em todas as regiões produtoras de milho também ocorrem fungos causadores de podridões de colmo, podridões de espiga e dos grãos. Àqueles também são responsáveis por podridões de espiga (REIS; CASA; BRESOLIN, 2004). Existem vários fungos causadores de podridões de espiga e consequentemente grãos ardidos em milho, sendo mais comumente encontrados os gêneros Fusarium, Aspergillus, Penicillium, Cladosporium, Cephalosporium e Stenocarpella (PINTO, 2001). Segundo Casa et al. (2005), as espigas atacadas por esses fungos apresentam redução no rendimento e qualidade dos grãos, e, por ocasião da comercialização é descontado um percentual do valor pago, em decorrência da incidência de grãos ardidos. Ainda, alguns destes fungos como Aspergillus spp., Fusarium spp. e Penicillium spp. podem acumular metabólitos secundários tóxicos ao homem e aos animais, denominados micotoxinas (REIS; CASA; BRESOLIN, 2004; FREIRE et al., 2007). Segundo alguns autores o fungo Fusarium verticillioides é o mais comumente encontrado em sementes de milho no Brasil (PINTO, 1996; REIS; CASA, 1996; CASA et al., 2004).

Ainda, segundo Reis, Casa e Bresolin (2004), os maiores danos com podridões de espiga acontecem em condições de alta umidade, no período de floração até a colheita.

Segundo classificação padrão oficial, atual e vigente do Ministério da Agricultura Pecuária e Abastecimento, constante na Instrução Normativa ${ }^{\circ}$ 60, de 22 de dezembro de 2011, 
quanto a classificação de grãos de milho, grãos ardidos são os grãos ou pedaços de grãos que apresentam escurecimento total, por ação do calor, umidade ou fermentação avançada atingindo a totalidade da massa do grão, sendo também considerados como ardidos, devido à semelhança de aspecto, os grãos totalmente queimados; e, grãos mofados, os grãos ou pedaços de grãos que apresentam contaminações fúngicas (mofo ou bolor) visíveis a olho nu, independentemente do tamanho da área atingida, bem como os grãos ou pedaços de grãos que apresentam coloração esverdeada ou azulada no germe, produzida pela presença de fungos (BRASIL, 2011). Ainda, para a mesma Instrução Normativa, fica definido que os limites de grãos ardidos tolerados para milho tipo 1 é até $1 \%$, tipo 2 até $2 \%$, tipo 3 até $3 \%$ e acima de $5 \%$ de grãos ardidos são considerados fora do padrão de qualidade.

De acordo com Pinto (2005) a coloração dos grãos ardidos de milho varia de acordo com o patógeno que o infectou, podendo variar de marrom-claro a roxo ou de vermelho claro a vermelho intenso. Os fungos responsáveis por essa deterioração dos grãos de milho podem ser divididos em dois grupos. Segundo Reis, Casa e Bresolin, (2004), o primeiro grupo inclui aqueles fungos que são agentes causais de podridões de espiga e que requerem alto conteúdo de umidade do grão (>18\%) para crescerem e se reproduzirem. Esses já colonizam os grãos em formação, e dificilmente infectam a cariopse após a maturação fisiológica. Já o segundo grupo inclui os fungos de armazenamento, àqueles que crescem melhores com umidade do grão abaixo de $18 \%$. No entanto, os mesmos afirmam que esses últimos patógenos também podem infestar ou infectar os grãos ainda na lavoura, principalmente em casos com espigas mal empalhadas e/ou se houver atraso na colheita e o milho permanecer muito tempo na lavoura, suscetível a insetos e chuvas. Ainda, segundo Oliveria et al. (2004), o déficit hídrico durante o período de enchimento de grãos e o excesso de chuvas após a maturação fisiológica, favorecem a contaminação de grãos pelos agentes patogênicos causadores de grãos ardidos.

Alguns dos fungos infectantes de grãos de milho podem produzir compostos tóxicos, que são metabólitos secundários produzidos por esses fungos em determinadas condições ambientais e de armazenamento não adequados, e que, impedem sua utilização para o consumo animal e humano devidos aos riscos à saúde (REIS; CASA; BRESOLIN, 2004; PINTO, 2005; OTTONI, 2008; FANTIN; DUARTE, 2009).

O controle de grãos ardidos é complexo já que esses são causados em grande maioria pelos mesmos fungos que causam podridão em colmos e espigas. Logo seu manejo envolve um conjunto de medidas. Segundo vários autores, medidas como resistência genética de cultivares, incorporação de restos culturais em casos mais severos, rotação de culturas, redução da 
densidade de plantas, tratamento de sementes com fungicidas, adubação equilibrada, melhor escolha do local e época de semeadura são importantes para desfavorecer os agentes causais das podridões de colmo e espiga (BARBOSA, 2010; PINTO, 2006; WOLOSHUK; WISE, 2011; SCHIPANKI, 2011).

Brito et al. (2012) mostraram que o controle químico com fungicidas de doenças foliares em milho contribuiu para redução da incidência de grãos ardidos.

\subsection{Fungicidas no controle de doenças em milho}

Segundo Agrios (2004), defensivos agrícolas são geralmente utilizados na proteção das superfícies das plantas contra uma infecção ou para erradicar um patógeno que já tenha infectado a planta. Ainda, segundo o autor, um dos métodos mais comuns de controlar doenças em lavouras, casas de vegetação e até em produtos armazenados é o uso de compostos químicos que são tóxicos aos patógenos, inibindo a germinação, crescimento e multiplicação dos patógenos ou mesmo sendo letal a estes. Os fungicidas podem ser utilizados para reduzir o inóculo inicial e/ou a taxa epidemiológica de uma doença (REIS; REIS; CARMONA, 2010).

Uma das causas do aumento em produtividade das lavouras de milho no Brasil e outros países tem sido atribuído à utilização de fungicidas no sistema de produção para o controle de doenças. Incrementos de 25 a 30 sacas/ha tem sido relatado pelo uso do controle químico de doenças em milho (COSTA; COTA, 2009). A redução de perdas de produtividade pelo ataque de patógenos na cultura do milho tem sido confirmado por resultados de pesquisa no país e no exterior (PINTO, 2004; JULIATTI et al., 2007; HARLAPUR et al., 2009)

Os fungicidas são ferramentas de grande importância para o manejo de doenças em diversas culturas de importância econômica e sua utilização tem contribuído de forma significativa para o aumento na produção de alimentos no Brasil e no mundo ao longo dos anos.

Os fungicidas utilizados no controle de doenças foliares em milho atualmente estão restritos a poucos grupos químicos, entre eles as estrobilurinas, triazóis e ditiocarbamatos. Benzimidazóis tem o uso restrito (BRANDÃO, 2002; JULIATTI, 2004; PEREIRA et al., 2005; DONATO; BONALDO, 2010). As estrobilurinas e triazóis são usados tanto isolados quanto em misturas um com o outro (SHAH; DILLARD, 2010) e também misturas formuladas (SILVA; SCHIPANSKI, 2007).

Os triazóis incluem um grupo de fungicidas em que seu mecanismo de ação envolve a inibição da biossíntese do ergosterol ou outros esteróis, danificando as membranas celulares do fungo e alterando sua permeabilidade, que tem como resultado a perda de seus elementos 
intracelulares. Também, causa a inibição da biossíntese dos triglicerídios e fosfolipídios do fungo, resultando na necrose celular. Os triazóis possuem ação protetora (não significativa), curativa e erradicante (REIS et al., 2010).

Os fungicidas ditiocarbamatos são fungicidas não penetrantes, protetores e residuais utilizados em muitas culturas mundo afora. É um grupo classificado pelo FRAC (Fungicide Resistance Action Committee (Comitê de Ação à Resistência de Fungicidas)) como fungicidas de ação multi-sítio, por interferir em diversos processos bioquímicos dentro do citoplasma da célula fúngica e mitocôndrias (KAARS-SIJPESTEIJN, 1984). Ainda segundo o autor, o efeito direto de destes produtos nos processos bioquímicos nucleares do fungo resulta na inibição da germinação de esporos dos fungos.

Já as estrobilurinas, segundo Reis; Reis e Carmona (2010) atuam inibindo a respiração mitocondrial dos fungos pelo bloqueio da transferência de elétrons entre o citocromo b e o citocromo $c_{1}$ no sítio $Q_{e}$, interferindo na produção de ATP. A germinação de esporos é a fase do ciclo biológico dos fungos com maior sensibilidade às estrobilurinas. Ainda, segundo o FRAC, as estrobilurinas, mais especificamente, inibem a respiração no complexo 3, citocromo bc 1 (FRAC, 2015). As estrobilurinas são mais efetivas nas fases iniciais do ciclo de vida dos patógenos, ou seja, na germinação dos esporos e nos processos iniciais de infecção (COSTA; COTA, 2009).

\subsubsection{Carboxamidas (SDHIs - inibidores do complexo II da cadeia respiratória)}

Em 1966 o composto de grupo químico oxathiin-carboxamides foram os primeiros fungicidas descobertos com atividade sistêmica. Este grupo incluía primeiramente os ingredientes ativos carboxina e oxicarboxina e, que, eram eficazes contra alguns carvões, ferrugens e Rhizoctonia. Estes compostos inibiam a succinato desidrogenase, uma importante enzima na respiração mitocondrial dos fungos (AGRIOS, 2004). Desta forma, em 1965, temse a introdução de grupo químico com diferente mecanismo de ação (AZEVEDO, 2007), os compostos inibidores de respiração no complexo 2, succinato desidrogenase (dehydrogenase succinato inhibitor (SDHI) (FRAC, 2015).

A introdução de novos fungicidas é essencial para se manter o controle dos principais patógenos na agricultura. Nas culturas de cereais, novos modos de ação são raros (novas introduções são todos SDHIs), e, parece ser mais frequente a descoberta de compostos para o controle de oomicetos (WALTER, 2011). Em 2003 foi lançada a molécula boscalida (grupo 
químico pyridine-carboxamides) dentro do grupo SDHI e isso representou um grande avanço neste grupo de modo de ação (SDHIs - inibidores do complexo II da cadeia respiratória).

Os compostos deste grupo - SDHI - FRAC CODE 7 (FRAC, 2015) são moléculas inibidoras da enzima succinato-desidrogenase (SDHI), também conhecida como complexo II da cadeia respiratória mitocondrial. A enzima encadeia o ciclo do ácido carboxílico e a respiração celular catalisando a oxidação do succinato à fumarato inserindo os elétrons via ubiquinona na cadeia respiratória. A inibição competitiva impede a redução da ubiquinona e interrompe a respiração mitocondrial e por fim, a produção de energia dentro das células fúngicas (KEON et al., 1991; MATSSON e HEDERSTEDT, 2001; GLÄTTLI et al., 2009).

A partir de 2010 novas moléculas do grupo dos SDHI e grupo químico pyrazole-4carboxamides foram lançadas mundialmente. Dentre as novas moléculas do grupo das carboxamidas estão Fluxapiroxade (Xemium), Benzovindiflupir (Solatenol) e Bixafen.

O Xemium, de nome comum Fluxapiroxade, é um fungicida carboxamida do grupo químico pyrazole-4-carboxamides de amplo espectro que controla importantes doenças das classes Basidiomicetos, Ascomicetos e Deuteromicetos. Depois de aplicado na planta, a molécula é distribuída sistemicamente via acropetal (xilema). O fungicida apresenta ainda ação preventiva, de longo período residual e também atividade curativa. Combinações com outros fungicidas como epoxiconazol e piraclostrobina promovem melhora no controle de doenças e manejo da resistência de fungos à fungicidas (SEMAR et al., 2011).

O ingrediente ativo Bixafen é um novo fungicida sistêmico do grupo químico pyrazole4-carboxamides dentro do grupo de resistência do FRAC número 7. O mesmo tem atividade de amplo espectro contra importantes doenças de culturas de cereais causados por fungos das classes Ascomicetos, Basidiomicetos e Deuteromicetos. Possui notável residual contra diversas doenças em cereais. O Bixafen possue completa atividade sistêmica, sendo absorvido pela cutícula e translocado pela planta via xilema. A velocidade de translocação é considerada moderada, sendo indicado promover uma boa distribuição do ingrediente ativo na folha inteira. Para prevenção e manejo da resistência deve ser combinado com fungicidas de diferentes modos de ação como o triazol protioconazol (SUTY-HEINZE et al., 2011).

O Solatenol, cujo nome comum é Benzovindiflupir, é um novo fungicida foliar de amplo espectro. O foco do projeto do Solatenol foi em descobrir composto com alta intrínseca atividade contra doenças em soja e cereais, em particular a ferrugem-asiática da soja (Phakopsora pachyrhizi) e mancha da folha por septoria (Zymoseptoria tritici). Solatenol é altamente ativo em outros patógenos importantes como Rhizoctonia spp. e Botrytis cinerea. 
Através de forte ligação com a camada de cera da folha, promove longo efeito residual de controle e, translocação mais lenta para o interior dos tecidos. Também, nas doses de 30 a $75 \mathrm{~g} \cdot \mathrm{ha}^{-1}$ é altamente ativo quando aplicado preventivamente ou cedo curativamente para os patógenos indicados (GUICHERIT et al., 2014).

\section{4. Índice de vegetação por diferença normalizada (NDVI)}

O índice de vegetação por diferença normalizada, conhecido como NDVI, utiliza dados de reflectância do vermelho (R) $(650 \mathrm{~nm})$ e infravermelho próximo (NIR) $(770 \mathrm{~nm})$, sendo calculado pela equação NDVI=(NIR-R)/(NIR+R).

Segundo Lamparelli et al. (2001) as plantas emitem e refletem radiação eletromagnética capaz de ser captada por sensores especiais sensíveis a determinados comprimentos de onda. Tal radiação remete a informações sobre o desenvolvimento e o estado sanitário das culturas.

O total de radiação solar absorvida pela folha é diretamente ligado à quantidade de pigmentos fotossintetizantes presentes na folha (GATES et al., 1964). Camp et al. (1982) avaliaram as mudanças nas enzimas fotossintéticas e atividades fotoquímicas em folhas de trigo no estádio vegetativo durante a senescência. Seu estudo mostrou que as folhas senescidas de trigo possuíam menor atividade fotossintética. Tal redução na fotossíntese foi então atribuída à perda total de cloroplastos.

O aumento de vegetação ou tecidos fotossinteticamente ativos aumentam a quantidade de luz absorvida no espectro eletromagnético vermelho e a luz refletida no espectro infravermelho próximo (FEDERER et al., 1966).

Há mais de vinte anos, trabalhos conduzidos por vários autores, mostraram que a radiação fotossinteticamente ativa absorvida poderia ser estimada a partir de observações multiespectrais (vermelho e infravermelho próximo) por sensores remotos (DAUGHTRY et al., 1983; ASRAR et al., 1984; WIEGAND et al., 1990).

A radiação solar é a fonte de energia para a fotossíntese. No entanto, esta energia é disponível para a planta apenas quando é absorvida pelo dossel vegetal. Apenas a radiação no intervalo de 400-700 $\mathrm{nm}$ de comprimento de onda mantem a fotossíntese em plantas verdes. Esta região do espectro é referida como radiação fotossinteticamente ativa (DAUGHTRY et al., 1992)

Ainda, segundo o autor, a vegetação responde diferentemente a radiação na porção visível e infravermelho do espectro solar. A radiação visível $(400-700 \mathrm{~nm})$ é fortemente absorvida pelos pigmentos fotossintéticos das plantas, enquanto que, a radiação infravermelha próxima (700-1300 nm) é fortemente refletida pela vegetação. 
Estudos revelaram que a refletância espectral de culturas agrícolas podem ser usados para detectar estresses abióticos e bióticos (FILELLA et al., 1995; OSBORNE et al., 2002), avaliar os status nutricional de plantas (ZHAO et al., 2005), estimar o desenvolvimento e a fisiologia das plantas (PEÑUELAS e FILELLA, 1998; SERRANO et al., 2000; ZHAO et al., 2003), e estimar o rendimento de culturas (MA et al., 2001).

O montante de energia refletida pelo dossel vegetal no vermelho e infravermelho próximo é diretamente relacionada com a atividade fotossintética das plantas (HOLBEN et al.,1980; DAUGHTRY et al., 1984). Plantas doentes normalmente apresentam o crescimento ou desenvolvimento reduzido e sintomas de amarelecimento, que resultam em contraste na resposta espectral em relação às saudáveis (BRENCHLEY, 1968).

Segundo Moreira (2007) a reflectância é dividida em regiões do comprimento de onda visível e do infravermelho próximo, médio e distante. Em plantas, a reflexão da luz é determinada pela clorofila, que reflete luz verde (visível) e absorve luz azul e vermelha. Portanto, quanto maior a taxa de clorofila na célula, maior será a reflectância de luz no comprimento de onda entre 0,5 e 0,6 $\mu \mathrm{m}$ e maior absorção de luz nas regiões de comprimento de onda entre 0,4 e 0,5 $\mu \mathrm{m}$ e entre 0,6 e 0,7 $\mu \mathrm{m}$ (TAIZ; ZEIGER, 2009).

O NDVI tem sido correlacionado com o teor de nitrogênio nas plantas, conteúdo de clorofila, biomassa foliar verde e rendimento de grãos (MA et al., 1996; SHANAHAN et al., 2003; SOLARI et al., 2008).

Ainda, segundo Zhao et al. (2007), os dois índices de vegetação de reflectâncias de banda larga, relação entre infravermelho próximo (NIR) e vermelho (índice de vegetação no vermelho - RVI), e o índice de vegetação por diferença normalizada (NDVI) tem sido largamente usados para avaliar a cobertura do solo por plantas, índice de área foliar, produção de biomassa e produtividade de culturas. Uma das conclusões dos autores, em seu trabalho com a cultura do algodão, foi que o NDVI na cultura aumentou até atingir um valor máximo próximo ao estádio fenológico da emissão da primeira flor. Os mesmos ainda afirmam que a correlação entre o rendimento de fibras com os índices de reflectância do dossel da cultura dependem do estádio da planta em que foram coletados. As diferenças de NDVI entre os tratamentos tiveram correlação linear com as diferenças de rendimento de fibras.

Vários estudos conduzidos sob manejo restrito quanto à irrigação e condições homogêneas de solo demonstraram a relação de NDVI e outros índices vegetativos com o rendimento final de grãos de milho. Os valores médios de NDVI cresceram até a emissão do pendão, entretanto, os valores no período da metade do enchimento de grãos mostraram-se 
melhor correlacionados com o rendimento final de grãos. Logo, este período de avaliação mostrou-se com maior potencial para se estimar a produtividade (SHANAHAN et al., 2001). 


\section{MATERIAL E MÉTODOS}

\subsection{Local do experimento, semeadura e manejo da cultura}

Os experimentos foram conduzidos durante a safra agrícola 2013/14 em área experimental do Instituto Phytus, localizada na Fazenda Cereal Citrus em Planaltina, Distrito Federal (Anexo 1). Foram realizados dois experimentos, sendo o primeiro com semeadura em 29 de novembro de 2013 e o segundo com semeadura em 22 de fevereiro de 2014. O objetivo principal da realização do experimento com duas épocas de semeadura (dois experimentos) foi a repetição do ensaio e a busca do máximo de doenças possíveis dentro de uma mesma safra agrícola com condições climáticas distintas, uma primeira com maior abundância de chuvas e outra com índices menores de precipitação pluviométrica.

Os ensaios localizaram-se nas coordenadas geográficas $15^{\circ} 40^{\prime} 01,52^{\prime \prime}$ de latitude Sul, $47^{\circ} 20^{\prime} 05,28^{\prime \prime}$ de longitude Oeste e altitude média de 876m (Anexo 1). O clima do local segundo classificação de Koppen é AW, clima tropical com estação seca definida no período do inverno. Já o solo do local é tido como Latossolo Vermelho. As informações de precipitação pluviométrica e temperaturas médias semanais das máximas e mínimas durante a condução dos experimentos 1 e 2 são demonstradas na figura 1 .

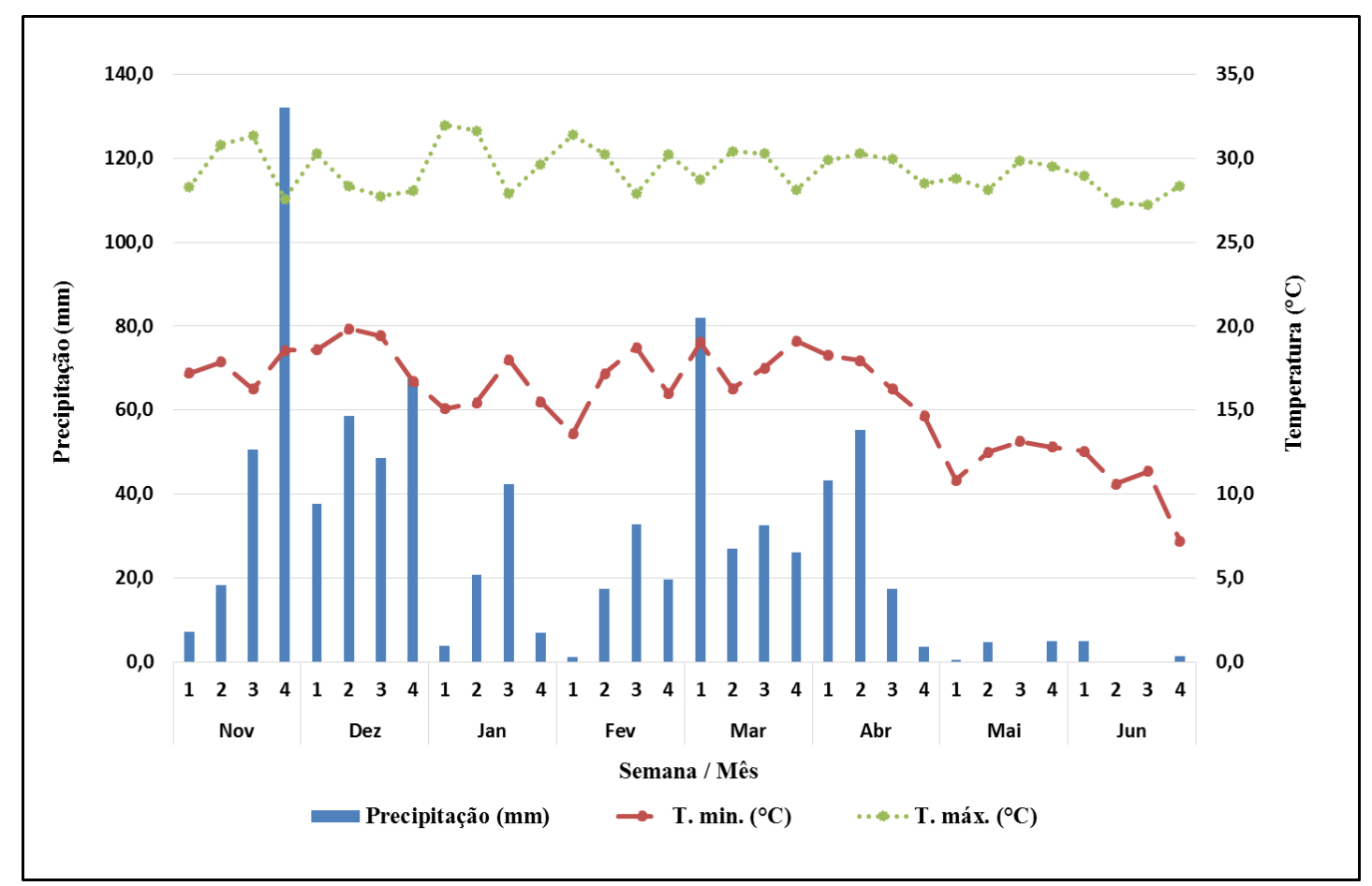

Figura 1. Precipitação pluviométrica e temperatura média semanal (mínima e máxima) ocorridas durante a condução dos experimentos 1 e 2. Planaltina/DF, 2014. 
A área experimental foi anteriormente cultivada com soja na safra 2012/13 e posteriormente, no inverno de 2013, mantida em pousio. Aos 15 e 2 dias antes da semeadura de ambos os ensaios, foi realizado o controle de plantas daninhas na área com $1860 \mathrm{~g} . \mathrm{ha}^{-1}$ de glifosato potássico.

A semeadura foi realizada com semeadora/adubadora Semeato modelo SHM $1113 \mathrm{com}$ espaçamento entrelinhas de $0,5 \mathrm{~m}$. A adubação de base constitui-se de $300 \mathrm{~kg}$. ha ${ }^{-1}$ de fertilizante NPK fórmula 11-52-00. Em pós-emergência do milho (adubação de cobertura) foram utilizados $150 \mathrm{~kg} \cdot \mathrm{ha}^{-1}$ de cloreto de potássio (00-00-60) quando o milho apresentava a primeira folha expandida com colar visível e, $300 \mathrm{~kg}$. ha-1 de uréia (45-00-00) parceladas em duas aplicações, nos estádios de quarta e sétima folha expandida com colar visível. A densidade de sementes utilizadas para todos os híbridos de milho foi 3,5 sementes por metro linear. As sementes foram tratadas com os fungicidas metalaxil (1,5 g/100 kg de sementes $)+$ fludioxonil (3,75 g/100 kg de sementes) e o inseticida tiametoxam (42 g/60.000 sementes).

Após a emergência, a população foi ajustada para 60 mil plantas por hectare através do desbaste do excedente.

Em pós-emergência da cultura do milho, em ambas as épocas de semeadura foram utilizados os herbicidas atrazina (2250 g.ha-1) e tembotriona (100 g.ha-1), aplicados aos 22 e 24 dias após a emergência da cultura, para a primeira e segunda época, respectivamente. Para o controle de pragas foram utilizados os inseticidas clorantraniliprole e tiametoxam + lambdacialotrina nas doses 20 g.ha-1 e 28,2 + 21,2 g.ha-1 respectivamente, em ambas as épocas de semeadura.

\subsection{Delineamento experimental e tratamentos}

Os experimentos foram conduzidos sob delineamento experimental de blocos completos ao acaso com parcelas subdivididas, com quatro repetições e em esquema fatorial (4x6). O fator A (híbridos) foi constituído por 4 híbridos de milho (tabelas 1 e 2) e o fator B (fungicidas) por um tratamento testemunha sem aplicação de fungicida e outros cinco tratamentos com aplicação de fungicidas, dentre eles um tratamento considerado controle total (aplicações com frequência de 10 dias) (tabela 2). As parcelas principais foram representadas pelos quatro híbridos de milho e as subparcelas pelos tratamentos fungicidas e a testemunha (tabela 2). Logo, a combinação dos fatores resultou em 24 tratamentos $(4 \times 6)$ e um total de 96 parcelas $(24 \times 4)$ por ensaio (Apêndice 6). 
As unidades experimentais constituíram-se de 5 linhas $(2,5 \mathrm{~m})$ de largura e $5 \mathrm{~m}$ de comprimento, totalizando $12,5 \mathrm{~m}^{2} \mathrm{o}$ tamanho de cada parcela. A área útil das parcelas, considerado para as avaliações e colheita, foi de 3 linhas $(1,5 \mathrm{~m})$ por $4 \mathrm{~m}$ de comprimento, totalizando $6 \mathrm{~m}^{2}$ de unidade experimental (Apêndice 5).

Tabela 1. Características dos híbridos de milho utilizados nos experimentos 1 (semeadura em 29/11/2013) e 2 (semeadura em 22/02/2014). Planaltina/DF, 2014.

\begin{tabular}{|c|c|c|c|c|}
\hline \multirow{2}{*}{ Características/Sanidade } & \multicolumn{4}{|c|}{ Híbridos ** } \\
\hline & DKB390 $^{8}$ & P30F539 $^{9}$ & FÓRMULA ${ }^{10}$ & $2 \mathrm{B587} 7^{11}$ \\
\hline Ciclo & Precoce & Precoce & Super-precoce & Precoce \\
\hline Tipo & Híbrido Simples & Híbrido Simples & Híbrido Simples & Híbrido Simples \\
\hline Mancha-branca $^{1}$ & $\mathrm{AT}^{*}$ & MS & MS & MR \\
\hline Cercosporiose $^{2}$ & MS & MS & MS & MR \\
\hline Mancha-de-turcicum ${ }^{3}$ & MS & MR & MR & MS \\
\hline Ferrugem-comum ${ }^{4}$ & MS & MS & MS & MR \\
\hline Ferrugem-polissora ${ }^{5}$ & MS & MS & MS & MS \\
\hline Mancha-de-cabatiela $^{6}$ & SI & SI & SI & SI \\
\hline Fusariose $^{7}$ & MT & $\mathrm{S}$ & MR & SI \\
\hline
\end{tabular}

* Nível de resistência às doenças, sendo AT $=$ altamente tolerante, $\mathrm{MT}=$ moderadamente tolerante, $\mathrm{MR}=$ moderadamente resistente, $\mathrm{MS}$ = moderadamente suscetível, $\mathrm{S}$ = suscetível, $\mathrm{SI}$ = sem informação. Fonte: Adaptado de EMBRAPA Milho e Sorgo, 2013. ** Genótipos com tecnologia Bt (Bacillus thuringiensis) ${ }^{1}$ P. maydis/P. ananatis; ${ }^{2}$ Cercospora zea-maydis; ${ }^{3}$ Exserohilum turcicum; ${ }^{4}$ Puccinia sorghi $;{ }^{5}$ Puccinia polysora $;{ }^{6}$ Kabatiella zeae $;{ }^{7}$ Fusarium spp.; ${ }^{8}$ Dekalb; ${ }^{9}$ Pioneer; ${ }^{10}$ Syngenta; ${ }^{11}$ Dow AgroSciences; 
Tabela 2. Fungicidas utilizados para o controle de doenças em diferentes híbridos de milho. Planaltina/DF, 2014.

\begin{tabular}{|c|c|}
\hline Parcelas principais & Subparcelas \\
\hline Híbridos de milho & Fungicidas (Dose de ingrediente ativo por hectare (g)) \\
\hline \multirow{6}{*}{ DKB 390} & Testemunha ${ }^{1}$ \\
\hline & Fluxapiroxade + Piraclostrobina + Adjuvante* $(50,1+99,9)^{2}$ \\
\hline & Benzovindiflupir + Azoxistrobina + Adjuvante ${ }^{* *}(49,5+99)^{2}$ \\
\hline & Bixafen + Trifloxistrobina + Protioconazol + Adjuvante $* * *(50+60+70)^{2}$ \\
\hline & Trifloxistrobina + Protioconazol + Adjuvante $* * *(75+87,5)^{2}$ \\
\hline & Controle Total ${ }^{3}$ \\
\hline \multirow{6}{*}{ P30F53 } & Testemunha $^{1}$ \\
\hline & Fluxapiroxade + Piraclostrobina + Adjuvante $*(50,1+99,9)^{2}$ \\
\hline & Benzovindiflupir + Azoxistrobina + Adjuvante ${ }^{* *}(49,5+99)^{2}$ \\
\hline & Bixafen + Trifloxistrobina + Protioconazol + Adjuvante $* * *(50+60+70)^{2}$ \\
\hline & Trifloxistrobina + Protioconazol + Adjuvante $* * *(75+87,5)^{2}$ \\
\hline & Controle Total ${ }^{3}$ \\
\hline \multirow{6}{*}{ FÓRMULA } & Testemunha $^{1}$ \\
\hline & Fluxapiroxade + Piraclostrobina + Adjuvante* $(50,1+99,9)^{2}$ \\
\hline & Benzovindiflupir + Azoxistrobina + Adjuvante $* *(49,5+99)^{2}$ \\
\hline & Bixafen + Trifloxistrobina + Protioconazol + Adjuvante $* * *(50+60+70)^{2}$ \\
\hline & Trifloxistrobina + Protioconazol + Adjuvante $* * *(75+87,5)^{2}$ \\
\hline & Controle Total ${ }^{3}$ \\
\hline \multirow{6}{*}{ 2B587 } & Testemunha $^{1}$ \\
\hline & Fluxapiroxade + Piraclostrobina + Adjuvante* $(50,1+99,9)^{2}$ \\
\hline & Benzovindiflupir + Azoxistrobina + Adjuvante ${ }^{* *}(49,5+99)^{2}$ \\
\hline & Bixafen + Trifloxistrobina + Protioconazol + Adjuvante $* * *(50+60+70)^{2}$ \\
\hline & Trifloxistrobina + Protioconazol + Adjuvante $* * *(75+87,5)^{2}$ \\
\hline & Controle Total ${ }^{3}$ \\
\hline
\end{tabular}

\footnotetext{
*Assist® a $0,5 \%$ v/v; **Aureo® a $0,5 \%$ v/v; ***Nimbus ${ }^{\circledR}$ a $0,5 \%$ v/v; ${ }^{1}$ Sem aplicação; ${ }^{2}$ Três aplicações; ${ }^{3}$ Oito aplicações (Fluxapyroxad + Piraclostrobin + Adjuvante* $\left(50,1+99,9\right.$ g. ha $\left.{ }^{-1}\right)$ ).
}

A aplicação dos tratamentos fungicidas foi realizada com pulverizador costal pressurizado à $\mathrm{CO}_{2}$ (pressão constante), barra de aplicação provida de 4 pontas de pulverização do tipo jato plano de faixa ampliada XR 110.02, espaçadas em 0,5m, pressão constante de 200 kPa e taxa de aplicação de 150 L. ha-1 ${ }^{-1}$ Todas as aplicações foram realizadas em momentos com as condições ideais ou mais favoráveis de temperatura e umidade relativa do ar, visando-se assim a correta deposição e absorção dos tratamentos fungicidas.

Foram realizadas três aplicações dos tratamentos fungicidas, sendo a primeira no estádio V8 (oito folhas expandidas com colar visível), a segunda no estádio VT (pendoamento) e a última aos 18 dias após a segunda aplicação. A exceção foram os tratamentos testemunha (sem 
aplicação fungicida) e Controle Total (aplicação a cada 10 dias (total de 8 aplicações)). As aplicações do tratamento Controle Total iniciaram-se no estádio de 7 folhas expandidas com colar visível (V7) e finalizaram-se no estádio de grão farináceo-duro (R5), em ambos os experimentos, totalizando as oito aplicações já mencionadas.

\subsection{Variáveis experimentais}

\section{a) Severidade e Área Abaixo da Curva de Progresso da Doença (AACPD)}

Para as avaliações de severidade de todas as doenças estudadas, foram consideradas todas as plantas na área útil da parcela (3 linhas centrais e $4 \mathrm{~m}$ de comprimento), desconsiderando-se assim a primeira e última linha de milho das laterais e $0,5 \mathrm{~m}$ na frente e no final de cada parcela. Foram realizadas seis avaliações de severidade, sendo as três primeiras nos estádios fenológicos V8 (oito folhas expandidas com colar visível), VT (pendoamento) e R2 (grão leitoso) e as demais de 10 em 10 dias coincidindo com os estádios R3, R4 e R5 das plantas de milho.

Foram avaliadas as doenças mancha-branca (Phaeosphaeria maydis/Pantoea ananatis), cercosporiose (Cercospora zeae-maydis), mancha de turcicum (Exserohilum turcicum), ferrugem polissora (Puccinia polysora), ferrugem comum (Puccinia sorghi) e mancha de cabatiela (Kabatiella zeae) (Apêndice 7). Nas avaliações foram consideradas todas as folhas das plantas de milho, desconsiderando-se aquelas senescidas naturalmente de baixo para cima.

Visando avaliar as doenças de forma mais acurada e precisa fez-se o uso de escalas diagramáticas para as doenças mancha-branca (EMBRAPA, 2010), mancha-de-turcicum (LAZAROTO et al., 2012) e mancha-de-cabatiela (CAMOCHENA et al., 2008). Para as demais doenças, na ausência de escalas diagramáticas disponíveis, estimou-se a porcentagem de área foliar com sintomas da doença visualmente.

Como se utilizaram diferentes híbridos de milho, nem sempre se teve as mesmas doenças ocorrendo em cada híbrido e nem mesmo iniciando-se simultaneamente. Logo, o número de avaliações para cada doença ocorrida diferiu de acordo com o híbrido, momento de ocorrência e época de plantio.

A partir dos dados de severidade calculou-se a Área Abaixo da Curva de Progresso da Doença (AACPD) (CAMPBELL; MADDEN, 1990) para todas as doenças avaliadas no 
experimento, permitindo-se assim melhor comparar e analisar os dados obtidos. A AACPD foi calculada a partir da seguinte equação:

$$
\mathbf{A A C P D}=\sum_{\mathbf{i}=\mathbf{1}}^{\mathbf{n}}\left[\left(\left(\mathbf{Y}_{\mathbf{i}+\mathbf{1}}+\mathbf{Y}_{\mathbf{i}}\right) * \mathbf{0 , 5}\right) *\left(\mathbf{T}_{\mathbf{i}+\mathbf{1}}-\mathbf{T}_{\mathbf{i}}\right)\right]
$$

Yi: severidade da doença na época de avaliação $i(i=1, \ldots, n)$;

$Y i+1$ : severidade da doença na época de avaliação $i+1$;

Ti: momento da avaliação inicial (i);

Ti+1: momento da próxima avaliação $(i+1)$;

$n=n^{o}$ de avaliações

Ainda, através dos dados de severidade calculou-se a porcentagem de eficácia (\%E) dos tratamentos fungicidas em relação ao tratamento testemunha. Para isso fez-se o uso da fórmula de Abbott (1925), conforme segue abaixo:

$\% E=\frac{T-F}{T} \times 100$

$\% \mathrm{E}=$ Porcentagem de eficácia

$T=$ Severidade média do tratamento testemunha

$F=$ Severidade no tratamento fungicida

\section{b) Grãos ardidos}

Para avaliação da incidência (\%) de grãos ardidos foram tomados 250 gramas de grãos no momento da colheita da porção total de grãos, e, após, foram previamente homogeneizados para obtenção de uma amostra representativa (Apêndice 8). Desta alíquota de grãos procedeuse a avaliação visual dos grãos sintomáticos, com descoloração de mais de um quarto da superfície total, em conformidade com o procedimento proposto pela Portaria $\mathrm{n}^{\circ} 11$ do Ministério da Agricultura Pecuária e Abastecimento, de 12 de abril de 1996 (BRASIL, 1996). A amostra de grãos sintomáticos foi então pesada para o cálculo da porcentagem de grãos ardidos da amostra original de 250 gramas.

\section{c) Patologia de grãos}

Para a análise dos patógenos presentes nos grãos de milho foi utilizado o método do papel filtro "blotter test" descrito no Manual de Análises Sanitárias de Sementes do Ministério da Agricultura, Pecuária e Abastecimento (MAPA, 2009). 
No momento da colheita foi tomada uma amostra de 400g de cada parcela, e, a partir desta foram extraídos de forma aleatória 400 grãos de milho para identificação e quantificação de patógenos presentes (Apêndice 8).

Para a análise, os grãos foram previamente desinfestados com hipoclorito de sódio (2\%) por cinco minutos e lavados com água deionizada. Após, os grãos foram distribuídos e acondicionados individualmente sobre uma camada de papel filtro umedecida (duas folhas de papel) em caixas tipo gearbox $(11 \mathrm{~cm} \times 11 \mathrm{~cm} \times 3 \mathrm{~cm})$, com cada caixa recebendo 50 grãos.

Para redução da germinação dos grãos, o substrato de papel foi umedecido com 2,4-D (2,4-diclorofenoxiacetato de sódio) a 5ppm de concentração. As caixas gearbox com os grãos foram então colocados sob lâmpadas de luz fluorescente branca e incubados por 7 dias. Após, realizou-se a identificação e quantificação dos patógenos presentes nos grãos com o auxílio de um microscópio estereoscópico. Os resultados foram expressos em percentual de grãos infectados.

\section{d) NDVI}

As leituras do NDVI [Índice de Vegetação por Diferença Normalizada (Normalized Difference Vegetation Index)] foram realizadas através do equipamento GreenSeeker® Handheld Crop Sensor fabricado pela empresa Trimble. O sensor GreenSeeker ${ }^{\circledR}$ realiza a leitura de reflectância no vermelho e infravermelho próximo e calcula o NDVI a partir da seguinte equação:

$\mathrm{NDVI}=(\rho \operatorname{ivp}-\rho v) /(\rho \mathrm{ivp}+\rho \mathrm{v})$

Onde,

NDVI= índice de vegetação por diferença normalizada

$\rho i v p=$ reflectância no infravermelho próximo $(770 \mathrm{~nm})$

$\rho v=$ reflectância no infravermelho $(650 \mathrm{~nm})$

O NDVI fornece uma informação espectral da cultura que remete ao estado nutricional e/ou sanitário da planta. Os valores de NDVI fornecidos pelo GreenSeeker® Handheld Crop Sensor podem variar de 0 a 0,99 , sendo que valores mais próximos de 0,99 indicam o quanto "mais verde" a planta se encontra (Apêndice 9).

Para as leituras de NDVI o sensor foi posicionado a 1m de altura do topo do dossel das plantas na parte central das unidades experimentais. Essa altura atende as recomendações do fabricante que são de 0,6 a 1,2m de altura do topo do dossel das culturas. Foram tomadas 5 
leituras por parcela e a média entre as leituras considerada como leitura final de cada unidade experimental.

\section{e) Massa de mil grãos}

Para a determinação da massa de mil grãos de milho foram coletadas amostras de 500 gramas, das quais, foram obtidas 6 subamostras de 100 grãos. Após a obtenção da massa destas seis subamostras, todos os valores foram multiplicados por 10, que resultaram nos valores utilizados para a análise estatística dos mesmos. Foi obtido o teor de água de todas as amostras e que posteriormente foram convertidas para $13 \%$ de umidade.

\section{f) Produtividade}

A produtividade de grãos de milho por hectare $\left(10.000 \mathrm{~m}^{2}\right)$ foi estimada através da colheita de espigas nos $6 \mathrm{~m}^{2}$ de área útil da parcela (3 fileiras centrais de largura por $4 \mathrm{~m}$ de comprimento) e, trilhadas com batedor estacionário. A amostra de grãos colhida de cada parcela foi devidamente identificada e acondicionada em saco de papel. Imediatamente após a colheita, todas as amostras foram levadas ao laboratório para pesagem e determinação do teor de água dos grãos (\% de umidade). Todos os valores obtidos da pesagem foram corrigidos para $13 \%$ de umidade. Tais valores, já corrigidos, foram então utilizados para se estimar a produtividade de grãos por hectare $\left(\mathrm{kg} \cdot \mathrm{ha}^{-1}\right)$.

Também, estimou-se a diferença percentual de produtividade de grãos dos tratamentos fungicidas utilizados no experimento, em relação à média de produtividade do tratamento testemunha (sem aplicação fungicida) dentro de cada híbrido utilizado no ensaio (incremento de produtividade).

\section{g) Análise estatística dos dados}

Os dados obtidos foram submetidos inicialmente aos testes de normalidade e quando necessário foram realizadas as transformações de acordo com sua natureza. Os dados de AACPD foram transformados em $\sqrt{x+5}, \%$ de grãos ardidos em $\log (x+1)$ e $\%$ de grãos com

Fusarium verticillioides em $\operatorname{arcsen} \sqrt{x / 100}$. Para os demais dados não foram necessárias transformações.

Após, os dados foram submetidos à análise de variância (ANOVA) e os efeitos, analisados pelo teste de Tukey para comparação múltipla de médias, a 5\% de probabilidade de erro $(\mathrm{p}<0,05)$. Tanto a análise de variância quanto os testes de comparação de médias foram 
realizados através do programa estatístico ASSISTAT® versão 7.7beta (SILVA; AZEVEDO, 2009).

Também, utilizaram-se as variáveis para a construção de uma matriz de correlação simples (Coeficiente de correlação linear de Pearson) através da aplicação do teste $t$ ao nível de 5\% de significância. Para tal, também foi utilizado o programa estatístico ASSISTAT® versão 7.7beta (SILVA; AZEVEDO, 2009). A classificação da intensidade da correlação entre as variáveis foi feita de acordo com Callegari-Jacques (2003). 


\section{RESULTADOS E DISCUSSÃO}

\subsection{Experimento 1}

\subsection{1 Área abaixo da curva de progresso da doença (AACPD)}

A análise de variância mostrou haver interação significativa entre os fatores A (Híbridos) e B (Fungicidas) quanto a variável Área Abaixo da Curva de Progresso da Doença (AACPD) para todas as doenças avaliadas (Apêndices 1 e 3). Todos os patógenos avaliados ocorreram de forma natural e em pressões suficientes para uma avaliação acurada dos tratamentos estudados.

Fórmula apresentou o maior valor médio de Área Abaixo da Curva de Progresso da Cercosporiose (AACPC), seguidos dos híbridos P30F53 e 2B587, todos estes diferindo estatisticamente entre si (tabela 3). O único híbrido a não apresentar a doença foi o DKB390, apresentando pela avaliação visual AACPC zero e, portanto, distinto dos demais genótipos. Entre os genótipos que manifestaram cercosporiose, 2B587 apresentou menor severidade da doença, o que corrobora com resultados de Brito (2010) no qual este híbrido enquadrou-se entre os mais resistentes à cercosporiose, porém não deixando de manifestar a doença. Quanto ao desempenho dos fungicidas, na média dos híbridos de milho, o tratamento Controle Total proporcionou o maior controle de cercosporiose, apresentando os menores valores de AACPC, distinto dos demais tratamentos. Desconsiderando-se o Controle Total, Bixafen+Trifloxistrobina+Protioconazol e Fluxapiroxade+Piraclostrobina apresentaram os menores valores de AACPC. Seguidos e distintos destes, Benzovindiflupir+Azoxistrobina e Trifloxistrobina+Protioconazol apresentaram AACPC inferiores e significativamente diferentes do tratamento Testemunha.

Considerando a interação existente entre híbridos e fungicidas, vale ressaltar que o híbrido Fórmula com maior severidade de cercosporiose apresentada, foi o genótipo mais responsivo ao controle químico com fungicidas contendo ingredientes ativos do grupo das carboxamidas. O híbrido 2B587, por ser aquele com maior tolerância à cercosporiose entre os materiais suscetíveis, foi o menos responsivo ao controle químico de modo geral. Entre as misturas com carboxamidas estudadas, Bixafen+Trifloxistrobina+Protioconazol e Fluxapiroxade+Piraclostrobina controlaram satisfatoriamente a cercosporiose na cultura do milho, comportamento este superior a mistura Benzovindiflupir+Azoxistrobina e a mistura entre triazol e estrobilurina Trifloxistrobina+Protioconazol. No genótipo P30F53, Bixafen+Trifloxistrobina+Protioconazol e Fluxapiroxade+Piraclostrobina controlaram a doença igualmente ao tratamento Controle Total, todos com valores de eficácia superiores a 
82\%. É importante ressaltar que a cercosporiose manifestou-se visualmente a partir do estádio de oito folhas de milho, tendo os tratamentos fungicidas iniciados em momento oportuno se observarmos a relação patógeno-hospedeiro para a doença. A exceção foi o tratamento Controle Total, iniciado antes deste estádio fenológico. O uso dos fungicidas contendo as moléculas carboxamidas Fluxapiroxade e Bixafen mostraram-se efetivas no controle do fungo necrotrófico Cercospora zeae nos híbridos de milho estudados. Não foram encontrados trabalhos com o uso de carboxamidas no controle de cercosporiose na cultura do milho.

No Brasil vários autores já relataram o controle da doença com misturas de estrobilurinas + triazóis com controle satisfatório (JULIATTI et al., 2004; COSTA, 2007; BRITO, 2007, 2010).

Tabela 3. Área abaixo da curva de progresso da cercosporiose (Cercospora zeae-maydis) (AACPC) e eficácia de controle (\%) na cultura do milho (Zea mays) em função da aplicação de diferentes tratamentos fungicidas e híbridos de milho. Planaltina/DF, 2014.

\begin{tabular}{|c|c|c|c|c|c|c|c|c|c|c|c|c|c|c|}
\hline \multirow{2}{*}{$\frac{\text { Fung.** }}{1}$} & \multicolumn{2}{|c|}{ DKB 390} & \multirow{2}{*}{$\frac{\text { Efic. }}{0^{2}}$} & \multicolumn{2}{|c|}{ P30F53 } & \multirow{2}{*}{$\begin{array}{c}\text { Efic. } \\
0\end{array}$} & \multicolumn{2}{|c|}{ FÓRMULA } & \multirow{2}{*}{$\begin{array}{c}\text { Efic. } \\
0\end{array}$} & \multicolumn{2}{|c|}{ 2B587 } & \multirow{2}{*}{$\begin{array}{c}\text { Efic. } \\
0\end{array}$} & \multicolumn{2}{|c|}{ Média } \\
\hline & $0^{1}$ & $\mathrm{dA}^{*}$ & & 196,6 & $\mathrm{bA}$ & & 631,4 & $\mathrm{aA}$ & & 106,3 & $\mathrm{cA}$ & & 233,6 & A \\
\hline 2 & 0 & $\mathrm{dA}$ & 0 & 32,6 & $\mathrm{bC}$ & 83,4 & 68,8 & $\mathrm{aC}$ & 89 & 18 & $\mathrm{cC}$ & 83 & 29,9 & $\mathrm{C}$ \\
\hline 3 & 0 & $\mathrm{cA}$ & 0 & 67,3 & $\mathrm{bB}$ & 65,7 & 160,9 & $\mathrm{aB}$ & 74,5 & 60,2 & bB & 43,4 & 72 & B \\
\hline 4 & 0 & $\mathrm{dA}$ & 0 & 33,6 & $\mathrm{bC}$ & 82,8 & 60 & $\mathrm{aC}$ & 90,4 & 22,8 & $\mathrm{cC}$ & 78,5 & 29,1 & $\mathrm{C}$ \\
\hline 5 & 0 & $\mathrm{cA}$ & 0 & 66,7 & bB & 66 & 144,5 & $\mathrm{aB}$ & 77 & 54,6 & bB & 48,6 & 66,4 & B \\
\hline 6 & 0 & $\mathrm{dA}$ & 0 & 24,4 & $\mathrm{bC}$ & 87,6 & 44,4 & $\mathrm{aD}$ & 92,9 & 9,2 & $\mathrm{cD}$ & 91,3 & 19,5 & D \\
\hline Média & 0 & d & & 70,2 & $\mathrm{~b}$ & & 185 & a & & 45,2 & $\mathrm{c}$ & & & \\
\hline
\end{tabular}

${ }^{1}$ AACPD; ${ }^{2}$ Eficácia de controle (\%) (Abbott, 1925); *Médias seguidas pela mesma letra, maiúscula na coluna e minúscula na linha, não diferem entre si pelo teste de Tukey $(\mathrm{p} \leq 0,05)$. Dados originais. Para efeito de análise os dados de AACPD foram transformados em $\sqrt{x+5}$; **Fungicidas: 1- Testemunha, 2- Fluxapiroxade + Piraclostrobina + Adjuvante $\left(50,1+99,9\right.$ g i.a. ha h $\left.^{-1}+0,5 \% \mathrm{v} / \mathrm{v}\right), 3-$ Benzovindiflupir + Azoxistrobina + Adjuvante $\left(49,5+99\right.$ g i.a. ha ${ }^{-1}+0,5 \%$ v/v $), 4-$ Bixafen + Trifloxistrobina + Protioconazol + Adjuvante $(50+60+70 \mathrm{~g}$ i.a. $\left.\mathrm{ha}^{-1}+0,5 \% \mathrm{v} / \mathrm{v}\right), 5-$ Trifloxistrobina + Protioconazol + Adjuvante $\left(75+87,5 \mathrm{~g}\right.$ i.a. ha $\left.{ }^{-1}+0,5 \% \mathrm{v} / \mathrm{v}\right), 6-$ Controle Total.

A doença mancha-branca ou mancha-de-feosféria (Phaeosphaeria maydis/Pantoea ananatis) estabeleceu-se em todos os quatro híbridos estudados, com valores de AACPMb (Área Abaixo da Curva de Progresso da Mancha-branca) distintos significativamente (tabela 4). A doença manifestou-se visivelmente a partir do florescimento da cultura do milho para todos os genótipos testados. Os híbridos Fórmula e P30F53 apresentaram os maiores valores de AACPMb, enquanto que, 2B587 e DKB390 os menores. O híbrido P30F53 já havia sido relatado como bastante suscetível a mancha-branca e DKB390 com menor suscetibilidade 
(BRITO, 2010). O 2B587 foi o mais tolerante a doença entre todos os genótipos, ao passo que Fórmula foi o mais suscetível a mancha-branca. O híbrido P30F53, apesar de apresentar a segunda maior média de AACPMb, foi aquele em que os tratamentos fungicidas mais reduziram a área abaixo da curva de progresso de mancha-branca, mostrando-se o mais responsivo ao controle químico em relação aos demais. Estes resultados são importantes haja vista a dificuldade já relatada por vários pesquisadores quanto ao controle da mancha-branca na cultura do milho com os fungicidas existentes no mercado. Fantin et al. (2006) estimaram perdas de produtividade de até $11 \%$ em híbridos com alta severidade de mancha-branca. Outros autores como Fernandes e Oliveira (1997) afirmam que híbridos suscetíveis à doença podem ter perdas na produção em torno de $60 \%$. A dificuldade relatada no controle da doença possivelmente pode ser devido a doença ser causada por fungo (Phaeosphaeria maydis) (FERNANDES; OLIVEIRA, 1997) em associação a bactéria que ocorre primeiramente (Pantoea ananatis) (PACCOLA-MEIRELLES et al., 2001), diferentemente dos demais patossistemas avaliadas no presente estudo. Juliatti et al. (2004, 2005) já haviam relatado a dificuldade de controle da mancha-branca na cultura do milho com alguns fungicidas, principalmente os triazóis.

Considerando a interação dos fatores, para fungicidas, o Controle Total apresentou a menor média de AACPMb, distintos dos demais tratamentos, seguidos por Bixafen+Trifloxistrobina+Protioconazol e Fluxapiroxade+Piraclostrobina com os segundos menores valores para a variável mas não distintos entre si. Em seguida, os fungicidas Trifloxistrobina+Protioconazol e Benzovindiflupir+Azoxistrobina, distintos entre si, mas superiores em controle apenas em relação ao tratamento Testemunha. O Controle Total proporcionou os menores valores de AACPMb na maioria dos híbridos com exceção ao 2B587, no qual o mesmo não diferiu dos fungicidas Bixafen+Trifloxistrobina+Protioconazol e Fluxapiroxade+Piraclostrobina. Apenas no Fórmula estes dois fungicidas não alcançaram 80\% de eficácia de controle. Nos híbridos DKB390 e 2 B587 os fungicidas Benzovindiflupir+Azoxistrobina e Trifloxistrobina+Protioconazol apresentaram comportamentos similares, superiores em controle apenas em relação a Testemunha sem aplicação, ao passo que nos genótipos P30F53 e Fórmula foram distintos entre si.

O fungicida Benzovindiflupir+Azoxistrobina apresentou, no geral, baixo controle de mancha-branca, o que pode ser observado pelos valores de AACPMb inferiores apenas em relação a Testemunha, com exceção o que ocorreu no híbrido DKB390 no qual esse valor foi inferior aquele observado por Trifloxistrobina+Protioconazol, porém não distinto 
significativamente deste. Este baixo controle da mancha-branca com o fungicida contendo triazól corrobora com informações relatadas anteriormente por alguns autroes.

De forma geral, Bixafen+Trifloxistrobina+Protioconazol e

Fluxapiroxade+Piraclostrobina apresentaram bom controle mancha-branca na cultura do milho, controle este superior a mistura triazól+estrobilurina Trifloxistrobina+Protioconazol.

Tabela 4. Área abaixo da curva de progresso da mancha-branca (Phaeosphaeria maydis/Pantoea ananatis) (AACPMb) e eficácia de controle (\%) na cultura do milho (Zea mays) em função da aplicação de diferentes tratamentos fungicidas e híbridos de milho. Planaltina/DF, 2014.

\begin{tabular}{|c|c|c|c|c|c|c|c|c|c|c|c|c|c|c|}
\hline \multirow{2}{*}{$\frac{\text { Fung.** }}{1}$} & \multicolumn{2}{|c|}{ DKB 390} & \multirow{2}{*}{$\begin{array}{c}\text { Efic. } \\
0^{2}\end{array}$} & \multicolumn{2}{|c|}{ P30F53 } & \multirow{2}{*}{$\begin{array}{c}\text { Efic. } \\
0\end{array}$} & \multicolumn{2}{|c|}{ FÓRMULA } & \multirow{2}{*}{$\begin{array}{c}\text { Efic. } \\
0\end{array}$} & \multicolumn{2}{|c|}{ 2B587 } & \multirow{2}{*}{$\begin{array}{c}\text { Efic. } \\
0\end{array}$} & \multicolumn{2}{|c|}{ Média } \\
\hline & $90,2^{1}$ & $\mathrm{cA}^{*}$ & & 244,4 & bA & & 293,1 & aA & & 58,1 & $\mathrm{dA}$ & & 171,5 & A \\
\hline 2 & 11,9 & $\mathrm{cC}$ & 86,8 & 20,3 & bD & 91,7 & 65,3 & $\mathrm{aD}$ & 77,7 & 7,7 & $\mathrm{cC}$ & 86,6 & 26,3 & D \\
\hline 3 & 47 & $\mathrm{cB}$ & 47,9 & 150, & bB & 38,5 & 198 & $\mathrm{aB}$ & 32,4 & 37,1 & $\mathrm{cB}$ & 36,1 & 108 & B \\
\hline 4 & 13,9 & $\mathrm{bC}$ & 84,6 & 20,7 & $\mathrm{bD}$ & 91,5 & 61,5 & $\mathrm{aD}$ & 79 & 6,2 & $\mathrm{cC}$ & 89,2 & 25,6 & D \\
\hline 5 & 52,1 & $\mathrm{cB}$ & 42,2 & 105,1 & $\mathrm{bC}$ & 57 & 152,4 & $\mathrm{aC}$ & 48 & 30,7 & $\mathrm{~dB}$ & 47,1 & 85,1 & $\mathrm{C}$ \\
\hline 6 & 3,7 & $\mathrm{cD}$ & 95,8 & 12,6 & $a b E$ & 94,8 & 18 & $\mathrm{aE}$ & 93,8 & 7,6 & $\mathrm{bcC}$ & 86,8 & 10,5 & E \\
\hline Média & 36,5 & $\mathrm{c}$ & & 92,2 & $\mathrm{~b}$ & & 131,4 & $\mathrm{a}$ & & 24,6 & d & & & \\
\hline $\mathrm{CV}(\%)$ & idos 7 & & & & & & & & $\%) \mathrm{Fu}$ & sicidas & 5,8 & & & \\
\hline
\end{tabular}

1AACPD; ${ }^{2}$ Eficácia de controle (\%) (Abbott, 1925); *Médias seguidas pela mesma letra, maiúscula na coluna e minúscula na linha, não diferem entre si pelo teste de Tukey $(\mathrm{p} \leq 0,05)$. Dados originais. Para efeito de análise os dados de AACPD foram transformados em $\sqrt{x+5}$; **Fungicidas: 1- Testemunha, 2- Fluxapiroxade + Piraclostrobina + Adjuvante (50,1 + 99,9 g i.a. ha-1 + 0,5\% v/v), 3- Benzovindiflupir + Azoxistrobina + Adjuvante $\left(49,5+99\right.$ g i.a. ha $a^{-1}+0,5 \%$ v/v $), 4-$ Bixafen + Trifloxistrobina + Protioconazol + Adjuvante $(50+60+70 \mathrm{~g}$ i.a. $\left.\mathrm{ha}^{-1}+0,5 \% \mathrm{v} / \mathrm{v}\right), 5$ - Trifloxistrobina + Protioconazol + Adjuvante $\left(75+87,5 \mathrm{~g}\right.$ i.a. $\left.\mathrm{ha}^{-1}+0,5 \% \mathrm{v} / \mathrm{v}\right), 6$ - Controle Total.

Quanto ao patógeno, também necrotrófico, Exserohilum turcicum, o mesmo não foi avaliado apenas no híbrido Fórmula, mais tolerante a este (tabela 5). Nos demais, a doença mancha-de-turcicum manifestou-se cedo na cultura, sendo avaliada já a partir do estádio de oito folhas expandidas de milho para todos os genótipos em que se manifestou. O híbrido que se mostrou mais tolerante a doença, dentre os avaliados, foi o 2 B587 e DKB390 o mais suscetível.Também, 2B587 mostrou-se o mais responsivo à aplicação de fungicidas para o controle de mancha-de-turcicum. Apesar das informações de que o genótipo P30F53 possue moderada resistência a doença, não foi o que ocorreu neste estudo, tendo este híbrido a segunda maior média de AACPD entre os genótipos estudados. Casela et al. (2006) relatam que os danos causados pela mancha-de-turcicum podem levar a uma perda de até 50\% dependendo da época de plantio e do momento em que a doença se manifesta na cultura do milho. 
Na média dos fungicidas, com exceção a Bixafen+Trifloxistrobina+Protioconazol e Fluxapiroxade+Piraclostrobina, todos os demais diferiram significativamente entre si. Todos os tratamentos fungicidas foram superiores a Testemunha, apresentando menores valores de Área Abaixo da Curva de Progresso da mancha-de-turcicum (AACPMt). No entanto, entre os patógenos necrotróficos avaliados no ensaio, Exserohilum turcicum mostrou-se aquele com maior dificuldade de controle, o que pode ser visto pelos baixos valores de eficácia para mancha-de-turcicum quando comparados as demais doenças foliares avaliadas no presente estudo. Um fator que pode ter contribuído para isto, é que, por ocasião do início das aplicações do fungicidas no ensaio, a doença já ocorria de forma mais visível em relação as demais ocorridas no experimento.

Considerando que todos os fungicidas testados são mais efetivos quando usados preventivamente, isto pode ter contribuído para o menor controle deste patógeno em relação aos demais fungos necrotróficos avaliados no experimento.

Nos híbridos P30F53 e 2B587, os fungicidas Bixafen+Trifloxistrobina+Protioconazol e Fluxapiroxade+Piraclostrobina apresentaram valores de AACPMt similares ao Controle Total, sendo que Trifloxistrobina+Protioconazol também não diferiu destes no genótipo 2B587. No híbrido de maior valor de AACPMt o Controle Total distinguiu-se dos demais tratamentos, seguidos de Fluxapiroxade+Piraclostrobina, Bixafen+Trifloxistrobina+Protioconazol, Trifloxistrobina+Protioconazol, e, Benzovindiflupir+Azoxistrobina, este último superior no controle apenas em relação a Testemunha.

Todos os tratamentos fungicidas testados, em todos os híbridos, apresentaram valores de eficácia de controle da mancha-de-turcicum inferiores a $80 \%$. 
Tabela 5. Área abaixo da curva de progresso da mancha-de-turcicum (Exserohilum turcicum) (AACPMt) e eficácia de controle (\%) na cultura do milho (Zea mays) em função da aplicação de diferentes tratamentos fungicidas e híbridos de milho. Planaltina/DF, 2014.

\begin{tabular}{|c|c|c|c|c|c|c|c|c|c|c|c|c|c|c|}
\hline \multirow{2}{*}{$\frac{\text { Fung. } * *}{1}$} & \multicolumn{2}{|c|}{ DKB 390} & \multirow{2}{*}{$\frac{\text { Efic. }}{0^{2}}$} & \multicolumn{2}{|c|}{ P30F53 } & \multirow{2}{*}{$\frac{\text { Efic. }}{0}$} & \multicolumn{2}{|c|}{ FÓRMULA } & \multirow{2}{*}{$\frac{\text { Efic. }}{0}$} & \multicolumn{2}{|c|}{ 2B587 } & \multirow{2}{*}{$\frac{\text { Efic. }}{0}$} & \multicolumn{2}{|c|}{ Média } \\
\hline & $436,2^{1}$ & $\mathrm{aA} *$ & & 236,7 & $\mathrm{bA}$ & & 0 & $\mathrm{dA}$ & & 123,3 & $\mathrm{cA}$ & & 199,1 & A \\
\hline 2 & 190,5 & $\mathrm{aD}$ & 56,3 & 76,2 & $\mathrm{bCD}$ & 67,8 & 0 & $\mathrm{dA}$ & 0 & 35,2 & $\mathrm{cC}$ & 71,4 & 75,5 & $\mathrm{D}$ \\
\hline 3 & 304,3 & $\mathrm{aB}$ & 30,2 & 100,9 & $\mathrm{bB}$ & 57,3 & 0 & $\mathrm{dA}$ & 0 & 54,6 & $\mathrm{cB}$ & 55,7 & 114,9 & B \\
\hline 4 & 202,1 & $\mathrm{aD}$ & 53,6 & 72,5 & $\mathrm{bD}$ & 69,3 & 0 & $\mathrm{dA}$ & 0 & 32,6 & $\mathrm{cC}$ & 73,5 & 76,8 & $\mathrm{D}$ \\
\hline 5 & 259 & $\mathrm{aC}$ & 40,6 & 91,0 & $\mathrm{bBC}$ & 61,5 & 0 & $\mathrm{dA}$ & 0 & 39,7 & $\mathrm{cC}$ & 67,8 & 97,4 & $\mathrm{C}$ \\
\hline 6 & 116,9 & $\mathrm{aE}$ & 73,2 & 64,8 & $\mathrm{bD}$ & 72,6 & 0 & $\mathrm{dA}$ & 0 & 31,8 & $\mathrm{cC}$ & 74,1 & 53,4 & $\mathrm{E}$ \\
\hline Média & 251,5 & $\mathrm{a}$ & & 107,0 & $\mathrm{~b}$ & & 0 & $\mathrm{~d}$ & & 52,9 & $\mathrm{c}$ & & & \\
\hline $\mathrm{CV}(\%) \mathrm{l}$ & dos & & & & & & & $(\%)$ & ungici & & 5,3 & & & \\
\hline
\end{tabular}

1AACPD; ${ }^{2}$ Eficácia de controle (\%) (Abbott, 1925); *Médias seguidas pela mesma letra, maiúscula na coluna e minúscula na linha, não diferem entre si pelo teste de Tukey $(\mathrm{p} \leq 0,05)$. Dados originais. Para efeito de análise os dados de AACPD foram transformados em $\sqrt{x+5}$; **Fungicidas: 1- Testemunha, 2- Fluxapiroxade + Piraclostrobina + Adjuvante (50,1 + 99,9 g i.a. ha-1 + 0,5\% v/v), 3- Benzovindiflupir + Azoxistrobina + Adjuvante $\left(49,5+99\right.$ g i.a. ha ${ }^{-1}+0,5 \%$ v/v $), 4-$ Bixafen + Trifloxistrobina + Protioconazol + Adjuvante $(50+60+70$ g i.a. $\left.\mathrm{ha}^{-1}+0,5 \% \mathrm{v} / \mathrm{v}\right), 5$ - Trifloxistrobina + Protioconazol + Adjuvante $\left(75+87,5 \mathrm{~g}\right.$ i.a. $\left.\mathrm{ha}^{-1}+0,5 \% \mathrm{v} / \mathrm{v}\right), 6$ - Controle Total.

A ferrugem-comum (Puccinia sorghi) foi avaliada em todos os quatro híbridos de milho, sendo a primeira doença a ser identificada no ensaio. O híbrido Fórmula apresentou a maior média de AACPFc, enquanto que o P30F53 a menor, todos distintos significativamente entre si (tabela 6). Os híbridos DKB390 e 2B587 apresentaram-se com comportamentos intermediários ao demais e semelhantes entre si. Brandão et al. (2003) apontou para reduções diferenciadas no progresso da doença em híbridos milho, sendo que híbridos mais resistentes tiveram até $70 \%$ de redução da AACPD enquanto que outros, menos tolerantes, reduções inferiores de $35 \%$ a $48 \%$. Ainda, segundo o autor, entre as doenças que se manifestam na cultura do milho, a ferrugem-comum tem sua importância elevada por comportar-se como fator de predisposição a outros patógenos causadores de doenças necrotróficas que ocorrem em sucessão na cultura do milho.

Ramos (2011) trabalhando com híbridos, épocas de aplicação e programas de controle químico, obteve controle eficiente da ferrugem-comum com três diferentes combinações de estrobilurinas e triazóis. Tais resultados corroboram aqueles obtidos por Juliatti et al. (2007), no qual uma mistura estrobilurina + triazól proporcionou bom controle da doença. Apesar do híbrido DKB390 ter seu tratamento Testemunha com a maior média de evolução da doença, verificado pela maior $\mathrm{AACPFc}$, foi o genótipo mais responsivo ao controle químico. Já Fórmula foi aquele menos responsivo. O tratamento Controle Total apresentou os menores valores de 
AACPFc em todos os híbridos. Além das inúmeras aplicações fungicidas deste tratamento, o mesmo iniciou-se anteriormente aos demais tratamentos, fato este que também contribuiu para o melhor desempenho. A doença não ocorreu de maneira muito severa, mas devido ao fato de ter ocorrido cedo no campo, pode ter prejudicado o controle de alguns tratamentos fungicidas. De acordo com Brandão et al. (2003), quando a ferrugem-comum ocorrer cedo em plantas jovens, o controle com fungicidas é favorecido se aplicado tão logo forem observadas as primeiras pústulas. Segundo Wegulo et al. (1998) em campos de produção de sementes no Estado de Iowa, Estados Unidos, o melhor controle de ferrugem-comum tem sido obtido com aplicações de fungicidas iniciando no estádio fenológico de cinco folhas expandidas do milho, ainda com baixa severidade.

Todos os fungicidas diferiram estatisticamente em relação a Testemunha. Fora o tratamento Controle Total, o fungicida Benzovindiflupir+Azoxistrobina foi aquele com melhor desempenho no controle da ferrugem-comum, como no híbrido DKB390 em que se diferenciou dos demais. Nos demais híbridos, mesmo não apresentando diferença estatística entre os demais, foi aquele que apresentou os menores valores de AACPFc, se desconsiderarmos o Controle Total. Benzovindiflupir+Azoxistrobina, depois do Controle Total foi aquele que apresentou os maiores valores de eficácia de controle da ferrugem-comum. $\mathrm{O}$ fungicida Bixafen+Trifloxistrobina+Protioconazol apresentou comportamento intermediário na média dos fungicidas, logo abaixo de Benzovindiflupir+Azoxistrobina, mas não diferente estatisticamente de Fluxapiroxade+Piraclostrobina, que por sua vez teve desempenho semelhante a Trifloxistrobina+Protioconazol. O fungicida contendo a carboxamida Benzovindiflupir mostrou ser aquele mais efetivo no controle da ferrugem-comum. 
Tabela 6. Área abaixo da curva de progresso da ferrugem-comum (Puccinia sorghi) (AACPFc) e eficácia de controle (\%) na cultura do milho (Zea mays) em função da aplicação de diferentes tratamentos fungicidas e híbridos de milho. Planaltina/DF, 2014.

\begin{tabular}{cccccccccccccccc}
\hline Fung.** & DKB & 390 & Efic. & \multicolumn{2}{c}{ P30F53 } & Efic. & FÓRMULA & Efic. & \multicolumn{2}{c}{2 B587 } & Efic. & Média \\
\hline 1 & $120,1^{1}$ & aA* & $0^{2}$ & 83 & cA & 0 & 101,4 & bA & 0 & 82,1 & cA & 0 & 96,6 & A \\
2 & 28,2 & bBC & 76,5 & 20,9 & cBC & 74,6 & 56,4 & aB & 44,4 & 32,5 & bB & 60,3 & 34,5 & BC \\
3 & 10 & dD & 91,6 & 16,2 & cC & 80,4 & 43,1 & aC & 57,5 & 24,6 & bC & 70 & 23,5 & D \\
4 & 22,4 & cC & 81,3 & 18,6 & cBC & 77,5 & 51,5 & aBC & 49,2 & 30,1 & bBC & 63,3 & 30,6 & $\mathrm{C}$ \\
5 & 33,2 & bB & 72,4 & 25,7 & cB & 68,9 & 51,3 & aBC & 49,4 & 33 & bB & 59,8 & 35,8 & B \\
6 & 5,6 & cE & 95,2 & 3,9 & cD & 95,2 & 31,1 & aD & 69,3 & 17,2 & bD & 79 & 14,5 & E \\
\hline Média & 36,6 & b & & 28 & c & & 55,8 & a & & 36,6 & b & & & \\
\hline
\end{tabular}

$\mathrm{CV}(\%)$ Híbridos 5,7

$\mathrm{CV}(\%)$ Fungicidas 6,0

1AACPD; ${ }^{2}$ Eficácia de controle (\%) (Abbott, 1925); *Médias seguidas pela mesma letra, maiúscula na coluna e minúscula na linha, não diferem entre si pelo teste de Tukey $(\mathrm{p} \leq 0,05)$. Dados originais. Para efeito de análise os dados de AACPD foram transformados em $\sqrt{x+5}$; **Fungicidas: 1- Testemunha, 2- Fluxapiroxade + Piraclostrobina + Adjuvante (50,1 + 99,9 g i.a. ha-1 + 0,5\% v/v), 3- Benzovindiflupir + Azoxistrobina + Adjuvante $\left(49,5+99\right.$ g i.a. ha ${ }^{-1}+0,5 \%$ v/v $), 4-$ Bixafen + Trifloxistrobina + Protioconazol + Adjuvante $(50+60+70$ g i.a. $\left.\mathrm{ha}^{-1}+0,5 \% \mathrm{v} / \mathrm{v}\right), 5$ - Trifloxistrobina + Protioconazol + Adjuvante $\left(75+87,5 \mathrm{~g}\right.$ i.a. $\left.\mathrm{ha}^{-1}+0,5 \% \mathrm{v} / \mathrm{v}\right), 6$ - Controle Total.

No experimento 1 a ferrugem-polissora (Puccinia polysora) ocorreu apenas no híbrido P30F53 (tabela 7), diferentemente da segunda época em que manifestou-se em mais híbridos, principalmente por encontrar neste período melhores condições para seu estabelecimento.

Todos os tratamentos fungicidas diferiram estatisticamente da Testemunha. Apesar do Controle Total apresentar a menor AACPFp, este não diferiu dos fungicidas Benzovindiflupir+Azoxistrobina, e Bixafen+Trifloxistrobina+Protioconazol. Os fungicidas Fluxapiroxade+Piraclostrobina e Trifloxistrobina+Protioconazol diferiram entre si e dos demais tratamentos, mas superiores em controle em relação a Testemunha. Apesar das diferenças estatísticas entre os tratamentos, todos os fungicidas e o Controle Total apresentaram baixos valores de AACPFp e eficácias de controle superiores a 94\% quando comparados a Testemunha sem aplicação. Apesar ser uma ferrugem mais agressiva que a comum, a ferrugempolissora evoluiu mais pronunciadamente na Testemunha, primeira com detecção da doença, apenas a partir do início do enchimento de grãos. Como já haviam sido feitas duas aplicações nos tratamentos fungicidas e mais de duas no Controle Total, a doença foi facilmente controlada, o que pode ser visto pelos dados de AACPFp. Assim como a mistura triazól + estrobilurina, todos os fungicidas contendo ingrediente ativo do grupo das carboxamidas foram eficientes no controle da ferrugem-polissora. 
Tabela 7. Área abaixo da curva de progresso da ferrugem-polissora (Puccinia polysora) (AACPFp) e eficácia de controle (\%) na cultura do milho (Zea mays) em função da aplicação de diferentes tratamentos fungicidas e híbridos de milho. Planaltina/DF, 2014.

\begin{tabular}{|c|c|c|c|c|c|c|c|c|c|c|c|c|c|c|}
\hline \multirow{2}{*}{$\frac{\text { Fung.** }}{1}$} & \multicolumn{2}{|c|}{ DKB 390} & \multirow{2}{*}{$\frac{\text { Efic. }}{0^{2}}$} & \multicolumn{2}{|c|}{ P30F53 } & \multirow{2}{*}{$\frac{\text { Efic. }}{0}$} & \multicolumn{2}{|c|}{ FÓRMULA } & \multirow{2}{*}{$\frac{\text { Efic. }}{0}$} & \multicolumn{2}{|c|}{ 2B587 } & \multirow{2}{*}{$\frac{\text { Efic. }}{0}$} & \multicolumn{2}{|c|}{ Média } \\
\hline & $0^{1}$ & $\mathrm{bA}^{*}$ & & 97,2 & $\mathrm{aA}$ & & 0 & $\mathrm{bA}$ & & 0 & $\mathrm{bA}$ & & 24,3 & A \\
\hline 2 & 0 & $\mathrm{bA}$ & 0 & 2,5 & $\mathrm{aC}$ & 97,4 & 0 & bA & 0 & 0 & $\mathrm{bA}$ & 0 & 0,6 & $\mathrm{BC}$ \\
\hline 3 & 0 & $\mathrm{aA}$ & 0 & 0,2 & $\mathrm{aD}$ & 99,7 & 0 & $\mathrm{aA}$ & 0 & 0 & $\mathrm{aA}$ & 0 & 0,06 & $\mathrm{C}$ \\
\hline 4 & 0 & $\mathrm{aA}$ & 0 & 1 & $\mathrm{aD}$ & 99 & 0 & $\mathrm{aA}$ & 0 & 0 & $\mathrm{aA}$ & 0 & 0,2 & $\mathrm{C}$ \\
\hline 5 & 0 & $\mathrm{bA}$ & 0 & 5,2 & $\mathrm{aB}$ & 94,6 & 0 & $\mathrm{bA}$ & 0 & 0 & $\mathrm{bA}$ & 0 & 1,3 & B \\
\hline 6 & 0 & $\mathrm{aA}$ & 0 & 0,1 & $\mathrm{aD}$ & 99,9 & 0 & $\mathrm{aA}$ & 0 & 0 & $\mathrm{aA}$ & 0 & 0,03 & $\mathrm{C}$ \\
\hline Média & 0 & $\mathrm{~b}$ & & 17,7 & $\mathrm{a}$ & & 0 & $\mathrm{~b}$ & & 0 & $\mathrm{~b}$ & & & \\
\hline $\mathrm{CV}(\%)$ & dos & & & & & & & $\mathrm{CV}$ & \%) Fuı & cide & 21,1 & & & \\
\hline
\end{tabular}

1AACPD; ${ }^{2}$ Eficácia de controle (\%) (Abbott, 1925); *Médias seguidas pela mesma letra, maiúscula na coluna e minúscula na linha, não diferem entre si pelo teste de Tukey $(\mathrm{p} \leq 0,05)$. Dados originais. Para efeito de análise os dados de AACPD foram transformados em $\sqrt{x+5}$; **Fungicidas: 1- Testemunha, 2- Fluxapiroxade + Piraclostrobina + Adjuvante (50,1 + 99,9 g i.a. ha-1 + 0,5\% v/v), 3- Benzovindiflupir + Azoxistrobina + Adjuvante $\left(49,5+99\right.$ g i.a. ha $a^{-1}+0,5 \%$ v/v $), 4-$ Bixafen + Trifloxistrobina + Protioconazol + Adjuvante $(50+60+70$ g i.a. $\left.\mathrm{ha}^{-1}+0,5 \% \mathrm{v} / \mathrm{v}\right), 5$ - Trifloxistrobina + Protioconazol + Adjuvante $\left(75+87,5 \mathrm{~g}\right.$ i.a. $\left.\mathrm{ha}^{-1}+0,5 \% \mathrm{v} / \mathrm{v}\right), 6$ - Controle Total.

A mancha-de-cabatiela ou mancha-ocular (Kabatiella zeae) manifestou-se apenas nos híbridos DKB390 e 2B587 (tabela 8). Os sintomas foram confirmados apenas a partir do estádio de início de enchimento de grãos da cultura do milho em ambos os híbridos. Não houve diferença significativa entre os híbridos nos quais a doença ocorreu.

Para os tratamentos fungicidas, todos diferiram estatisticamente da Testemunha, na média dos híbridos. O Controle Total apresentou a menor média de AACPMc, estatisticamente diferente aos demais. Os fungicidas Bixafen+Trifloxistrobina+Protioconazol e Fluxapiroxade+Piraclostrobina apresentaram bons níveis de controle da mancha-de-cabatiela, com eficácia de controle superiores a 80\% e baixos valores de AACPMc. Ambos não diferiram estatisticamente entre si. Já os fungicidas Trifloxistrobina+Protioconazol e Benzovindiflupir+Azoxistrobina apresentaram valores intermediários de AACPMc, distintos entre si e da Testemunha. De modo geral, os tratamentos contendo carboxamidas, com exceção a mistura formulada Benzovindiflupir+Azoxistrobina, foram eficientes na redução da AACPMc e controle da doença nos híbridos estudados. Informação esta de muita importância já que não existem fungicidas registrados para o controle da mancha-de-cabatiela no Brasil e, por ser uma doença de crescente importância e ocorrência nas principais regiões produtoras de milho no país. 
Tabela 8. Área abaixo da curva de progresso da mancha-de-cabatiela (Kabatiella zeae) (AACPMc) e eficácia de controle (\%) na cultura do milho (Zea mays) em função da aplicação de diferentes tratamentos fungicidas e híbridos de milho. Planaltina/DF, 2014.

\begin{tabular}{|c|c|c|c|c|c|c|c|c|c|c|c|c|c|c|}
\hline \multirow{2}{*}{$\frac{\text { Fung.** }}{1}$} & \multicolumn{2}{|c|}{ DKB 390} & \multirow{2}{*}{$\frac{\text { Efic. }}{0^{2}}$} & \multicolumn{2}{|c|}{ P30F53 } & \multirow{2}{*}{$\frac{\text { Efic. }}{0}$} & \multicolumn{2}{|c|}{ FÓRMULA } & \multirow{2}{*}{$\frac{\text { Efic. }}{0}$} & \multicolumn{2}{|c|}{ 2B587 } & \multirow{2}{*}{$\frac{\text { Efic. }}{0}$} & \multicolumn{2}{|c|}{ Média } \\
\hline & $90,2^{1}$ & $\mathrm{aA}^{*}$ & & 0 & $\mathrm{bA}$ & & 0 & $\mathrm{bA}$ & & 97,5 & $\mathrm{aA}$ & & 46,9 & A \\
\hline 2 & 16,7 & $\mathrm{aCD}$ & 81,4 & 0 & $\mathrm{bA}$ & 0 & 0 & $\mathrm{bA}$ & 0 & 14,4 & $\mathrm{aC}$ & 85,2 & 7,8 & D \\
\hline 3 & 32,2 & $\mathrm{aB}$ & 64,2 & 0 & $\mathrm{bA}$ & 0 & 0 & $\mathrm{bA}$ & 0 & 30,4 & $\mathrm{aB}$ & 68,8 & 15,6 & B \\
\hline 4 & 13,9 & $\mathrm{aD}$ & 84,6 & 0 & $\mathrm{cA}$ & 0 & 0 & $\mathrm{cA}$ & 0 & 9,7 & $b D$ & 90 & 5,9 & D \\
\hline 5 & 20,6 & $\mathrm{bC}$ & 77,1 & 0 & $\mathrm{cA}$ & 0 & 0 & $\mathrm{cA}$ & 0 & 26,1 & $\mathrm{aB}$ & 73,2 & 11,7 & $\mathrm{C}$ \\
\hline 6 & 6,7 & $\mathrm{aE}$ & 92,5 & 0 & $\mathrm{bA}$ & 0 & 0 & $\mathrm{bA}$ & 0 & 6,2 & $\mathrm{aE}$ & 93,6 & 3,2 & $\mathrm{E}$ \\
\hline Média & 30,1 & $\mathrm{a}$ & & 0 & $\mathrm{~b}$ & & 0 & b & & 30,7 & $\mathrm{a}$ & & & \\
\hline $\mathrm{CV}(\%)$ & ridos & 8,3 & & & & & & $(\%)$ & Fungic & & 9,3 & & & \\
\hline
\end{tabular}

1AACPD; ${ }^{2}$ Eficácia de controle (\%) (Abbott, 1925); *Médias seguidas pela mesma letra, maiúscula na coluna e minúscula na linha, não diferem entre si pelo teste de Tukey $(\mathrm{p} \leq 0,05)$. Dados originais. Para efeito de análise os dados de AACPD foram transformados em $\sqrt{x+5}$; **Fungicidas: 1- Testemunha, 2- Fluxapiroxade + Piraclostrobina + Adjuvante (50,1 + 99,9 g i.a. ha-1 + 0,5\% v/v), 3- Benzovindiflupir + Azoxistrobina + Adjuvante $\left(49,5+99\right.$ g i.a. ha $a^{-1}+0,5 \%$ v/v $), 4-$ Bixafen + Trifloxistrobina + Protioconazol + Adjuvante $(50+60+70$ g i.a. $\left.\mathrm{ha}^{-1}+0,5 \% \mathrm{v} / \mathrm{v}\right), 5$ - Trifloxistrobina + Protioconazol + Adjuvante $\left(75+87,5 \mathrm{~g}\right.$ i.a. ha $\left.\mathrm{h}^{-1}+0,5 \% \mathrm{v} / \mathrm{v}\right)$, 6- Controle Total.

\subsubsection{Grãos ardidos}

A análise de variância mostrou haver interação significativa entre os fatores híbridos e fungicidas para a variável incidência de grãos ardidos (Apêndices 1 e 3).

As condições meteorológicas ocorridas no final do período de enchimento de grãos e início da maturação fisiológica da cultura do milho, no experimento 1 , favoreceu a ocorrência de grãos ardidos. Em geral, não houve muita variação entre os híbridos na média da porcentagem de grãos ardidos (tabela 9). Com exceção ao híbrido P30F53, com os maiores valores de grãos ardidos, os demais híbridos mostraram-se similares estatisticamente, com valores em média inferiores a esse híbrido. Em trabalho realizado por Mendes (2009), a porcentagem de grãos ardidos foi também influenciada pelo tipo de híbrido e pelas safras agrícolas. Ainda, na média dos híbridos, daquele com menor porcentagem de grãos ardidos, 2B587, ao maior, P30F53, os valores variaram de $1,65 \%$ a 2,8\% respectivamente. Ao analisar as Testemunhas de cada genótipo percebe-se que os valores de grãos ardidos são maiores, variando de 5\% no P30F53 a 1,95\% no 2B587. O 2B587 foi o híbrido em que os tratamentos fungicidas menos influenciaram no controle de grãos ardidos, verificados pelos baixos valores de eficácia em relação à Testemunha.

Na média dos tratamentos fungicidas, a Testemunha apresentou a maior ocorrência de grãos ardidos, 3,3\%, significamente distinta dos demais tratamentos. O tratamento com menor 
incidência foi $\mathrm{o}$ Controle Total com 1,25\%. Os demais fungicidas, Bixafen+Trifloxistrobina+Protioconazol e Fluxapiroxade+Piraclostrobina e Trifloxistrobina+Protioconazol apresentaram controle de grãos ardidos similares. Este último, no entanto, não diferiu de Benzovindiflupir+Azoxistrobina.

De maneira geral todos os tratamentos fungicidas reduziram a incidência de grãos ardidos, porém, nem sempre de modo significativo. A aplicação de fungicidas visando a redução de grãos ardidos em milho já haviam sido relatadas por Juliatti et al. (2007) e Duarte et al. (2009), quando da utilização de misturas de estrobilurinas e triazóis aplicados via foliar promoveu a redução na incidência de grãos ardidos de milho. Dados de Brito (2010) corroboram com estes autores já que também obteve reduções na incidência de grãos ardidos em tratamentos com aplicação de fungicidas. $\mathrm{N}$

No híbrido 2B587, com exceção ao Controle Total, nenhum fungicida diferenciou-se de maneira significativa em relação à Testemunha sem controle. Já nos híbridos DKB390 e P30F53, todos os fungicidas diferenciaram-se em relação à Testemunha, com menores porcentagens de grãos ardidos. Já no Fórmula, apenas o fungicida Benzovindiflupir+Azoxistrobina não diferiu significativamente do tratamento Testemunha. Apesar das reduções de grãos ardidos a aplicação dos fungicidas foliares não foi efetiva no controle.

Tabela 9. Incidência de grãos ardidos (\%) e eficácia de controle (\%) na cultura do milho (Zea mays) em função da aplicação de diferentes tratamentos fungicidas e híbridos de milho. Planaltina/DF, 2014.

\begin{tabular}{|c|c|c|c|c|c|c|c|c|c|c|c|c|c|c|}
\hline \multirow{2}{*}{$\begin{array}{c}\text { Fung.** } \\
1\end{array}$} & \multicolumn{2}{|c|}{ DKB 390} & \multirow{2}{*}{$\begin{array}{c}\text { Efic. } \\
0^{2}\end{array}$} & \multicolumn{2}{|c|}{ P30F53 } & \multirow{2}{*}{$\frac{\text { Efic. }}{0}$} & \multicolumn{2}{|c|}{ FÓRMULA } & \multirow{2}{*}{$\begin{array}{c}\text { Efic. } \\
0\end{array}$} & \multicolumn{2}{|c|}{ 2B587 } & \multirow{2}{*}{$\frac{\text { Efic. }}{0}$} & \multicolumn{2}{|c|}{ Média } \\
\hline & $3,1^{1}$ & $\mathrm{bA}^{*}$ & & 5 & $\mathrm{aA}$ & & 3,1 & $\mathrm{bA}$ & & 1,9 & $\mathrm{cA}$ & & 3,3 & A \\
\hline 2 & 0,9 & $\mathrm{cC}$ & 69 & 2,6 & $\mathrm{aBC}$ & 48,5 & 1,2 & $\mathrm{bcB}$ & 60,4 & 1,8 & $a b A$ & 6,4 & 1,6 & $\mathrm{C}$ \\
\hline 3 & 2,1 & $\mathrm{abB}$ & 33,3 & 2,8 & $\mathrm{aB}$ & 44,5 & 2,1 & $a b A$ & 30,6 & 1,6 & bAB & 16,6 & 2,2 & B \\
\hline 4 & 1,3 & $\mathrm{bC}$ & 57,1 & 2,1 & $\mathrm{aBC}$ & 58,5 & 1,3 & bB & 58 & 1,6 & $a b A B$ & 17,9 & 1,6 & $\mathrm{C}$ \\
\hline 5 & 1,6 & $\mathrm{bBC}$ & 48,4 & 2,5 & $\mathrm{aBC}$ & 49,5 & 1,4 & bB & 55,6 & 1,9 & $a b A$ & 3,8 & 1,8 & $\mathrm{BC}$ \\
\hline 6 & 1,2 & $\mathrm{bC}$ & 61,9 & 1,9 & $\mathrm{aC}$ & 62,5 & 0,9 & bB & 71,7 & 1,0 & bB & 46,1 & 1,2 & $\mathrm{D}$ \\
\hline Média & 1,7 & $\mathrm{~b}$ & & 2,8 & $\mathrm{a}$ & & 1,7 & $\mathrm{~b}$ & & 1,6 & b & & & \\
\hline $\mathrm{CV}(\%) \mathrm{H}$ & idos & 15,9 & & & & & & $(\%) \mathrm{F}$ & ungici & & 12,6 & & & \\
\hline
\end{tabular}

1'Incidência de grãos ardidos (\%); ${ }^{2}$ Eficácia de controle (\%) (Abbott, 1925); *Médias seguidas pela mesma letra, maiúscula na coluna e minúscula na linha, não diferem entre si pelo teste de Tukey $(\mathrm{p} \leq 0,05)$. Dados originais. Para efeito de análise os dados de incidência de grãos ardidos foram transformados em $\log (\mathrm{x}+1)$. **Fungicidas: 1Testemunha, 2- Fluxapiroxade + Piraclostrobina + Adjuvante $\left(50,1+99,9\right.$ g i.a. ha $a^{-1}+0,5 \%$ v/v $)$, 3Benzovindiflupir + Azoxistrobina + Adjuvante (49,5 + $99 \mathrm{~g}$ i.a. $\left.\mathrm{ha}^{-1}+0,5 \% \mathrm{v} / \mathrm{v}\right), 4-$ Bixafen + Trifloxistrobina + Protioconazol + Adjuvante $\left(50+60+70 \mathrm{~g}\right.$ i.a. ha $\left.^{-1}+0,5 \% \mathrm{v} / \mathrm{v}\right), 5$ - Trifloxistrobina + Protioconazol + Adjuvante $\left(75+87,5\right.$ g i.a. ha ${ }^{-1}+0,5 \%$ v/v $), 6$ - Controle Total. 


\subsubsection{Patologia de grãos (Incidência de Fusarium verticillioides)}

Os resultados da análise de patologia de grãos de milho de todos os híbridos estudados mostraram altas incidências de Fusarium verticillioides (tabela 10). A interação entre os fatores híbridos e fungicidas foi significativa (Apêndices 1 e 3).

Os híbridos P30F53 e DKB390 apresentaram as maiores médias de incidência de Fusarium sp. nos grãos de milho, não diferindo estatisticamente entre si. Já o genótipo 2B587 foi aquele em que obteve-se a menor média de incidência do fungo nos grãos, diferindo dos demais híbridos. Já o Fórmula mostrou-se com média intermediária em relação aos demais híbridos e distintos significativamente destes. Houve uma grande variação ao compararmos os híbridos, já que 2B587, com 24,67\% de incidência de Fusarium sp. nos grãos foi o menos infectado, e, P30F53, com 71,92\% o mais infectado pelo patógeno.

É importante ressaltar que as condições climáticas ocorridas no experimento 1 foram favoráveis ao patógeno. O efeito dos fungicidas sobre Fusarium sp. nos grãos de milho foi suficiente para reduzir a infecção a índices menores do que ocorreu no tratamento Testemunha. São resultados interessantes principalmente porque atualmente existe muita dificuldade no controle de patógenos em grãos e espigas de milho, principalmente pelo uso de fungicidas via foliar. Este controle tem importância também porque fungos de grãos como Fusarium spp. são capazes de produzir metabólitos secundários, como as micotoxinas, que são tóxicas aos animais e humanos. Resultados diferentes são obtidos quando do controle de $F$. verticillioides via tratamento de sementes, com fungicidas obtendo eficácia superior a 90\% (NERBASS, 2008).

O Controle Total, com aplicações frequentes de fungicidas, não foi suficiente para manter a incidência do fungo em baixos níveis. Diferentemente do controle de doenças foliares, o controle de patógenos de grãos como Fusarium sp. mostrou não haver uma tendência clara entre os tratamentos fungicidas utilizados, fato este comprovado pelo Controle Total, com várias aplicações em que não foi suficiente para diferenciá-lo dos demais tratamentos. $\mathrm{O}$ fungicida Benzovindiflupir+Azoxistrobina não diferiu do Controle Total. No entanto, esse também não diferiu de Fluxapiroxade+Piraclostrobina, que por sua vez apresentou controle similar a Trifloxistrobina+Protioconazol e Bixafen+Trifloxistrobina+Protioconazol. 
Tabela 10. Incidência de Fusarium verticillioides (\%) em grãos de milho e eficácia de controle (\%) em função da aplicação de diferentes tratamentos fungicidas e híbridos de milho. Planaltina/DF, 2014.

\begin{tabular}{|c|c|c|c|c|c|c|c|c|c|c|c|c|c|c|}
\hline \multirow{2}{*}{$\frac{\text { Fung.** }}{1}$} & \multicolumn{2}{|c|}{ DKB 390} & \multirow{2}{*}{$\begin{array}{c}\text { Efic. } \\
0^{2}\end{array}$} & \multicolumn{2}{|c|}{ P30F53 } & \multirow{2}{*}{$\frac{\text { Efic. }}{0}$} & \multicolumn{2}{|c|}{ FÓRMULA } & \multirow{2}{*}{$\frac{\text { Efic. }}{0}$} & \multicolumn{2}{|c|}{ 2B587 } & \multirow{2}{*}{$\frac{\text { Efic. }}{0}$} & \multicolumn{2}{|c|}{ Média } \\
\hline & $78,5^{1}$ & $\mathrm{bA}^{*}$ & & 99 & $\mathrm{aA}$ & & 47,5 & $\mathrm{cA}$ & & 50 & $\mathrm{cA}$ & & 68,7 & A \\
\hline 2 & 64 & $\mathrm{aB}$ & 18,4 & 73 & $\mathrm{aBC}$ & 25,1 & 43 & $\mathrm{bAB}$ & 9,5 & 21,5 & $\mathrm{cB}$ & 57 & 50,4 & $\mathrm{BC}$ \\
\hline 3 & 60 & $\mathrm{aB}$ & 23,5 & 61,5 & $\mathrm{aC}$ & 36,9 & 41 & $\mathrm{bAB}$ & 13,6 & 17,5 & $\mathrm{cB}$ & 65 & 45 & CD \\
\hline 4 & 71,5 & $\mathrm{aAB}$ & 8,9 & 80,5 & $\mathrm{aB}$ & 17,4 & 40,5 & $\mathrm{bAB}$ & 14,7 & 18,5 & $\mathrm{cB}$ & 63 & 52,7 & B \\
\hline 5 & 69 & $\mathrm{aAB}$ & 12 & 75 & $\mathrm{aB}$ & 23 & 43 & $\mathrm{bAB}$ & 9,4 & 20,5 & $\mathrm{cB}$ & 59 & 51,9 & B \\
\hline 6 & 67,5 & $\mathrm{aAB}$ & 14 & 42,5 & $\mathrm{bD}$ & 56,4 & 34 & $\mathrm{bB}$ & 28,4 & 20 & $\mathrm{cB}$ & 60 & 41 & $\mathrm{D}$ \\
\hline Média & 68,4 & $\mathrm{a}$ & & 71,9 & $\mathrm{a}$ & & 41,5 & $\mathrm{~b}$ & & 24,7 & $\mathrm{c}$ & & & \\
\hline $\mathrm{CV}(\%) \mathrm{H}$ & dos 1 & & & & & & & $(\%)$ & ungici & & 7,7 & & & \\
\hline
\end{tabular}

${ }^{1}$ Incidência de Fusarium verticillioides (\%); ${ }^{2}$ Eficácia de controle (Abbott, 1925); *Médias seguidas pela mesma letra, maiúscula na coluna e minúscula na linha, não diferem entre si pelo teste de Tukey $(\mathrm{p} \leq 0,05)$. Dados originais. Para efeito de análise os dados de incidência de Fusarium verticillioides foram transformados em $\operatorname{arcsen} \sqrt{x / 100}$. $*$ Fungicidas: 1 - Testemunha, 2- Fluxapiroxade + Piraclostrobina + Adjuvante $(50,1+99,9 \mathrm{~g}$ i.a. $\left.\mathrm{ha}^{-1}+0,5 \% \mathrm{v} / \mathrm{v}\right), 3-$ Benzovindiflupir + Azoxistrobina + Adjuvante (49,5 + $99 \mathrm{~g}$ i.a. ha $\left.\mathrm{h}^{-1}+0,5 \% \mathrm{v} / \mathrm{v}\right), 4-$ Bixafen + Trifloxistrobina + Protioconazol + Adjuvante $\left(50+60+70\right.$ g i.a. ha $\left.{ }^{-1}+0,5 \% \mathrm{v} / \mathrm{v}\right), 5-$ Trifloxistrobina + Protioconazol + Adjuvante $\left(75+87,5\right.$ g i.a. ha $\mathrm{ha}^{-1}+0,5 \%$ v/v $), 6$ - Controle Total.

\subsubsection{Produtividade de grãos}

Apesar do acumulado de chuvas durante os meses de janeiro e fevereiro de 2014 ficarem abaixo das médias históricas para a região, a produtividade de grãos de milho do experimento 1 foi pouco afetada, o que pode ser visto pelos resultados obtidos pelos diferentes híbridos de milho utilizados no ensaio, e, sob os diferentes programas de controle químico com utilização de fungicidas com ingredientes ativos do grupo das carboxamidas.

A severidade das doenças avaliadas foi suficiente para redução da produtividade de grãos nos quatro híbridos. Diferentemente às variáveis já discutidas até agora, como aquelas ligadas aos patossistemas estudados, não houve interação significativa entre os fatores híbridos de milho e fungicidas para a variável produtividade de grãos (Apêndices 1 e 3). Todos os fungicidas afetaram positivamente a produtividade de grãos nos híbridos, apesar de alguns não diferirem estatisticamente, o que mostra o efeito positivo do controle de doenças foliares sobre o rendimento final do milho (tabela 11). Vários autores já mostraram a importância de se manter a área foliar verde das plantas de milho principalmente próximo e após o florescimento, e também a importância das folhas próximas à espiga ao enchimento de grãos (PALMER, 1984; FANCELLI, 1988; FISCHER; PATAKY, 1992).

O híbrido 2B587 apresentou os maiores níveis de produtividade, o que pode ser observado pela maior média entre todos os genótipos estudados e diferindo estatisticamente dos 
demais. Já o híbrido Fórmula foi aquele com a menor média entre os híbridos, e, distinto significativamente de todos outros. Os híbridos DKB390 e P30F53 apresentaram médias intermediárias de produtividade de grãos, não diferindo significativamente entre si. Todos os tratamentos fungicidas diferiram significativamente do tratamento Testemunha. $\mathrm{O}$ efeito do controle químico de doenças em milho com fungicidas e o seu reflexo na produtividade de grãos já foi relatada por vários autores (PINTO, 2004; JULIATTI et al., 2004; BONALDO et al., 2008; BRITO, 2010; RAMOS, 2011).

O Controle Total, apesar de apresentar a maior média de produtividade, não diferiu dos fungicidas Bixafen+Trifloxistrobina+Protioconazol e Fluxapiroxade+Piraclostrobina. Estes, por sua vez, não diferenciaram-se significativamente de Trifloxistrobina+Protioconazol e Benzovindiflupir+Azoxistrobina. É importante ressaltar que todos os fungicidas, Bixafen+Trifloxistrobina+Protioconazol, Fluxapiroxade+Piraclostrobina e Benzovindiflupir+Azoxistrobina contendo carboxamidas dentre os ingredientes ativos, contribuíram para manutenção de maiores níveis de produtividade quando comparados a Testemunha. Os fungicidas Bixafen+Trifloxistrobina+Protioconazol e Fluxapiroxade+Piraclostrobina, mesmo que similares estatisticamente ao fungicida triazól + estrobilurina apresentaram médias de produtividade de grãos de milho superiores a este.

$\mathrm{Na}$ cultura do trigo, Berdugo et al. (2012) relataram o aumento significativo em produtividade e massa de mil grãos com o uso de Bixafen e Protioconazol. Ainda, segundo os autores, experimentos conduzidos em condições livres de doenças, fungicidas pertencentes aos grupos químicos pirazol-carboxamidas, estrobilurinas e triazóis tiveram efeitos positivos no desenvolvimento das plantas e rendimento de grãos. Ao analisar o incremento de produtividade pelo uso de fungicidas em relação a média de produtividade do tratamento Testemunha sem aplicação, o híbrido Fórmula apresentou as maiores porcentagens de incremento de produtividade de grãos pela utilização de fungicidas no controle de doenças.

O incremento de produtividade neste híbrido variou de $24,2 \%$ a $47 \%$, para os tratamentos Benzovindiflupir+Azoxistrobina e Controle Total, respectivamente, o que comprova a resposta do híbrido ao controle químico de doenças foliares do milho. No híbrido DKB390 o comportamento foi semelhante a este, tendo os tratamentos Benzovindiflupir+Azoxistrobina e Controle Total, os menores e maiores incrementos na produtividade de grãos, respectivamente. Os resultados de produtividade para o híbrido Fórmula, aquele com as maiores severidades de cercosporiose e mancha-branca, mostram que estas duas doenças quando ocorrendo no mesmo genótipo possuem alto potencial de redução 
da produtividade de milho. Brito et al. (2007) observaram reduções na produtividade de milho devido a cercosporiose de até $27 \%$ na região Sul de Minas Gerais.

Nos híbridos P30F53 e 2B587, os menores e maiores incrementos foram obtidos com Trifloxistrobina+Protioconazol e Controle Total, respectivamente. Todos os tratamentos fungicidas resultaram em acréscimos no rendimento final, resultados estes que corroboram com os obtidos por Jardine e Laca-Buendía (2009).

Em todos os híbridos de milho estudados os tratamentos com os fungicidas Bixafen+Trifloxistrobina+Protioconazol e Fluxapiroxade+Piraclostrobina apresentaram incremento na produtividade de grãos inferiores apenas ao tratamento Controle Total.

As menores respostas ao uso de fungicidas em termos de produtividade puderam ser observadas no híbrido 2B587 no qual tem-se as menores porcentagens de incremento de produtividade. Brito (2010) encontrou a mesma resposta para este híbrido, sendo que este, com ou sem aplicação fungicida mantivera alto nível de produtividade.

De modo geral todos os tratamentos com fungicidas tiveram acréscimos na produtividade de grãos. Brito (2010) mencionara que o controle de doenças com fungicidas em híbridos de milho fizera com que estes pudessem melhor expressar seu potencial genético para a produção de grãos.

Como em todos os híbridos teve-se um múltiplo patossistema atuando simultaneamente sobre os mesmos, é difícil mensurar o quanto cada patógeno contribuiu para a redução da produtividade. Existem muitos trabalhos com a tentativa de estimar o quanto determinada doença pode afetar esta variável, no entanto, é muito dependente do genótipo utilizado, condições ambientais, época, local, entre outros fatores. 
Tabela 11. Produtividade de grãos (kg.ha $\left.{ }^{1-}\right)$ da cultura do milho (Zea mays) e incremento de produtividade $(\%)$ em função da aplicação de diferentes tratamentos fungicidas e híbridos de milho. Planaltina/DF, 2014.

\begin{tabular}{|c|c|c|c|c|c|c|c|c|c|c|c|c|c|c|}
\hline \multirow{2}{*}{$\frac{\text { Fung.** }}{1}$} & \multicolumn{2}{|c|}{ DKB 390} & \multirow{2}{*}{$\frac{\text { I.P. }}{0^{2}}$} & \multicolumn{2}{|c|}{ P30F53 } & \multirow{2}{*}{$\frac{\text { I.P. }}{0}$} & \multicolumn{2}{|c|}{ FÓRMULA } & \multirow{2}{*}{$\frac{\text { I.P. }}{0}$} & \multicolumn{2}{|c|}{ 2B587 } & \multirow{2}{*}{$\frac{\text { I.P. }}{0}$} & \multicolumn{2}{|c|}{ Média } \\
\hline & $8012^{1}$ & $b B^{*}$ & & 8485 & $\mathrm{abB}$ & & 6608 & $\mathrm{cC}$ & & 9633 & $\mathrm{aB}$ & & 8184 & $\mathrm{C}$ \\
\hline 2 & 9957 & $\mathrm{abA}$ & 24 & 9831 & $\mathrm{bAB}$ & 16 & 8959 & bAB & 36 & 11141 & $\mathrm{aA}$ & 16 & 9972 & $\mathrm{AB}$ \\
\hline 3 & 9189 & $\mathrm{bcAB}$ & 15 & 9477 & $\mathrm{bAB}$ & 12 & 8207 & $\mathrm{cB}$ & 24 & 10814 & $\mathrm{aAB}$ & 12 & 9422 & B \\
\hline 4 & 9981 & bA & 25 & 9649 & $\mathrm{bAB}$ & 14 & 9263 & bAB & 40 & 11245 & $\mathrm{aA}$ & 17 & 10034 & $\mathrm{AB}$ \\
\hline 5 & 9572 & $\mathrm{abA}$ & 20 & 9283 & $a b A B$ & 9 & 8892 & bAB & 35 & 10420 & $\mathrm{aAB}$ & 8 & 9542 & B \\
\hline 6 & 10442 & $\mathrm{abA}$ & 30 & 10127 & $\mathrm{abA}$ & 19 & 9712 & $\mathrm{bA}$ & 47 & 11275 & $\mathrm{aA}$ & 17 & 10389 & A \\
\hline Média & 9525 & $\mathrm{~b}$ & & 9475 & $\mathrm{~b}$ & & 8607 & $\mathrm{c}$ & & 10755 & $\mathrm{a}$ & & & \\
\hline $\mathrm{CV}(\%$ & Híbrido & 6,0 & & & & & & $V(\%)$ & ungi & & 7,0 & & & \\
\hline
\end{tabular}

${ }^{1}$ Produtividade de grãos (Kg.ha $\left.{ }^{-1}\right)$; ${ }^{2}$ Incremento de produtividade (I.P.) em relação ao tratamento Testemunha (\%); * Médias seguidas pela mesma letra, maiúscula na coluna e minúscula na linha, não diferem entre si pelo teste de Tukey ( $\mathrm{p} \leq 0,05)$. **Fungicidas: 1 - Testemunha, 2- Fluxapiroxade + Piraclostrobina + Adjuvante $(50,1+99,9$ g i.a. $\left.\mathrm{ha}^{-1}+0,5 \% \mathrm{v} / \mathrm{v}\right), 3-$ Benzovindiflupir + Azoxistrobina + Adjuvante $\left(49,5+99 \mathrm{~g}\right.$ i.a. ha $\left.\mathrm{ha}^{-1}+0,5 \% \mathrm{v} / \mathrm{v}\right)$, 4- Bixafen + Trifloxistrobina + Protioconazol + Adjuvante $\left(50+60+70\right.$ g i.a. ha $\left.{ }^{-1}+0,5 \% \mathrm{v} / \mathrm{v}\right), 5-$ Trifloxistrobina + Protioconazol + Adjuvante $\left(75+87,5\right.$ g i.a. ha ha $\left.^{-1}+0,5 \% \mathrm{v} / \mathrm{v}\right), 6$ - Controle Total.

\subsubsection{Massa de mil grãos (MMG)}

Para o componente de rendimento massa de mil grãos, diferentemente da produtividade de grãos, a análise de variância mostrou haver interação significativa entre os fatores híbridos e fungicidas (Apêndices 1 e 3).

Todos os híbridos de milho apresentaram diferenças significativas quando analisadas as medias de massa de mil grãos para cada um destes (tabela 12). O híbrido DKB390 obteve a maior média para MMG, enquanto que Fórmula, a menor. Entre híbridos essas diferenças são esperadas já que essa variável, na média, é intrínseca de cada genótipo de milho.

Quanto as médias entre os tratamentos fungicidas, todos diferiram significativamente da Testemunha com valores superiores para MMG, corroborando com os resultados obtidos por Ramos (2011) e contrários àqueles obtidos por Zanatta (2013). O Controle Total diferenciouse de todos os demais tratamentos com a maior média para essa variável.

Segundo Ritchie et al. (1993), próximo de $80 \%$ da matéria seca dos grãos de milho é acumulada 15 dias após a polinização. Este fato também pode explicar a média superior do Controle Total em relação a todos os demais fungicidas, já que este teve sucessivas aplicações, de dez em dez dias a partir do estádio de sete folhas expandidas, o que, manteve as plantas mais protegidas e com maior área verde fotossinteticamente ativa, contribuindo assim para um melhor enchimento de grãos. Os fungicidas Fluxapiroxade+Piraclostrobina e 
Bixafen+Trifloxistrobina+Protioconazol apresentaram comportamento semelhantes entre si, porém inferiores ao Controle Total. Já os fungicidas Trifloxistrobina+Protioconazol e Benzovindiflupir+Azoxistrobina, similares entre si, apresentaram valores de MMG inferiores aos anteriores mas superiores ao tratamento Testemunha.

Ainda, na média dos fungicidas, o componente MMG variou de 307,71 a 354,56 g para o pior e melhor tratamento, a Testemunha e o Controle Total, respectivamente. Semelhante ao que ocorreu para produtividade de grãos, o híbrido Fórmula foi aquele em que teve-se os maiores valores de incremento na massa de mil grãos com os tratamentos fungicidas, incrementos estes que variaram de $19,8 \%$ a $25,6 \%$. O mesmo ocorreu com o híbrido 2B587 obtendo os menores valores de incremento para a variável massa de mil grãos. O tratamento Controle Total diferiu significativamente dos demais fungicidas apenas no híbrido DKB390, sendo que nos demais obteve comportamento similar a alguns fungicidas, como no híbrido P30F53, em que igualou-se ao fungicida Fluxapiroxade+Piraclostrobina, no Fórmula assemelhou-se ao Bixafen+Trifloxistrobina+Protioconazol e por fim no híbrido 2B587, aos fungicidas Bixafen+Trifloxistrobina+Protioconazol e Fluxapiroxade+Piraclostrobina. No genótipo DKB390 os fungicidas não diferiram significativamente entre si, com exceções apenas os tratamentos Controle Total e Testemunha, com a maior e menor média de MMG.

Tabela 12. Massa de mil grãos (g) (MMG) de milho e incremento na massa de mil grãos (\%) em função da aplicação de diferentes tratamentos fungicidas e híbridos de milho. Planaltina/DF, 2014.

\begin{tabular}{|c|c|c|c|c|c|c|c|c|c|c|c|c|c|c|}
\hline \multirow{2}{*}{$\frac{\text { Fung.** }}{1}$} & \multicolumn{2}{|c|}{ DKB 390} & \multirow{2}{*}{$\begin{array}{c}\text { I.M. } \\
0^{2}\end{array}$} & \multicolumn{2}{|c|}{ P30F53 } & \multirow{2}{*}{$\begin{array}{c}\text { I.M. } \\
0\end{array}$} & \multicolumn{2}{|c|}{ FÓRMULA } & \multirow{2}{*}{$\begin{array}{c}\text { I.M. } \\
0\end{array}$} & \multicolumn{2}{|c|}{ 2B587 } & \multirow{2}{*}{$\begin{array}{c}\text { I.M. } \\
0\end{array}$} & \multicolumn{2}{|c|}{ Média } \\
\hline & $340^{1}$ & $\mathrm{aC}^{*}$ & & 305 & $\mathrm{cE}$ & & 254 & $\mathrm{dD}$ & & 331 & $\mathrm{bD}$ & & 308 & D \\
\hline 2 & 368 & $\mathrm{aB}$ & 8 & 353 & $\mathrm{cAB}$ & 16 & 309 & $\mathrm{dBC}$ & 22 & 361 & bAB & 9 & 348 & B \\
\hline 3 & 365 & $\mathrm{aB}$ & 7 & 347 & bCD & 13 & 305 & $\mathrm{cC}$ & 20 & 350 & $\mathrm{bC}$ & 6 & 342 & C \\
\hline 4 & 365 & $\mathrm{aB}$ & 7 & 350 & $\mathrm{cBC}$ & 14 & 314 & $\mathrm{dAB}$ & 23 & 360 & bAB & 9 & 347 & B \\
\hline 5 & 369 & $\mathrm{aB}$ & 8 & 344 & $\mathrm{cD}$ & 12 & 307 & $\mathrm{dC}$ & 21 & 356 & bB & 8 & 344 & C \\
\hline 6 & 378 & $\mathrm{aA}$ & 11 & 358 & $\mathrm{cA}$ & 17 & 320 & dA & 26 & 363 & bA & 10 & 355 & A \\
\hline Média & 364 & $\mathrm{a}$ & & 343 & $\mathrm{c}$ & & 302 & d & & 354 & b & & & \\
\hline
\end{tabular}

${ }^{1}$ Massa de mil grãos (g); ${ }^{2}$ Incremento na massa de mil grãos (I.M.) em relação ao tratamento Testemunha (\%);

*Médias seguidas pela mesma letra, maiúscula na coluna e minúscula na linha, não diferem entre si pelo teste de Tukey ( $\mathrm{p} \leq 0,05)$.**Fungicidas: 1- Testemunha, 2- Fluxapiroxade + Piraclostrobina + Adjuvante $(50,1+99,9$ g i.a. $\left.\mathrm{ha}^{-1}+0,5 \% \mathrm{v} / \mathrm{v}\right), 3-$ Benzovindiflupir + Azoxistrobina + Adjuvante $\left(49,5+99 \mathrm{~g}\right.$ i.a. ha $\left.\mathrm{h}^{-1}+0,5 \% \mathrm{v} / \mathrm{v}\right), 4-\mathrm{Bixafen}$ + Trifloxistrobina + Protioconazol + Adjuvante $\left(50+60+70\right.$ g i.a. ha $\left.{ }^{-1}+0,5 \% \mathrm{v} / \mathrm{v}\right), 5-$ Trifloxistrobina + Protioconazol + Adjuvante $\left(75+87,5\right.$ g i.a. ha ${ }^{-1}+0,5 \%$ v/v), 6- Controle Total. 


\subsection{6 Índice de vegetação por diferença normalizada (NDVI)}

Para a variável Índice de Vegetação por Diferença Normalizada (NDVI) foi realizada a análise de variância por avaliação (V8, VT, R3 e R5) (tabela 13) (Apêndices 2 e 4). Ao analisarmos as análises de variância percebemos nitidamente o comportamento do NDVI nas plantas de milho pelos diferentes híbridos (genótipos) e diferentes fungicidas, incluindo a Testemunha e o Controle Total.

O principal objetivo do tratamento Controle Total no presente estudo foi ter um tratamento no qual tivesse o mínimo possível de doenças para uma melhor comparação e compreensão do comportamento da variável NDVI em estudo. Por se tratar de um ensaio de campo é lógico que não foi possível ter nível de doença zero no Controle Total, mas conseguiuse ter o mínimo possível para usarmos como parâmetro no estudo do NDVI. Logo, esperou-se com o tratamento Controle Total ter um tratamento com plantas mais sadias possíveis. Como o NDVI expressa o quanto mais verde e sadia as plantas estão, era muito importante ter um tratamento "padrão" de comparação, principalmente, em relação ao tratamento Testemunha, sem aplicação fungicida. Também é de se esperar que ocorra um aumento no valor de NDVI a medida que a cultura vai se desenvolvendo e emitindo mais folhas, aumentando a cobertura do dossel vegetal. Dentro de um mesmo híbrido em iguais condições de desenvolvimento, teoricamente, seriam esperadas respostas similares em NDVI. Qualquer alteração em algum fator que leve a planta ter uma resposta morfo-fisiológica distinta refletirá em alteração do NDVI dependendo da magnitude de tal alteração.

Pela análise de variância dos dados de NDVI em cada avaliação observa-se que no estádio V8, como era de se esperar, não há interação entre os fatores híbridos (A) e fungicidas (B) (Apêndices 2 e 4). Tem se nesta avaliação diferenças significativas apenas entre os híbridos, sendo que DKB390 e 2B587 não diferiram entre si apresentando as maiores médias de NDVI, e, Fórmula e P30F53, similares entre si apresentaram as menores médias (tabela 13). É importante ressaltar que características morfológicas intrínsecas de cada híbrido e o fechamento do dossel de plantas influenciam nas leituras de NDVI, que expressa também a biomassa de cada genótipo, nas parcelas avaliadas. Nesta avaliação é possível observar que não há efeito de fungicidas nas leituras de NDVI das plantas de milho, uma vez que, com exceção ao Controle Total, os tratamentos fungicidas têm suas aplicações iniciadas no estádio de oito folhas de milho expandidas.

Já na avaliação realizada em VT (pendoamento) percebe-se que além da variação que existia entre híbridos, inicia-se a partir deste momento diferenças significativas entre os 
tratamentos fungicidas (Apêndices 2 e 4). É também neste momento, que visualmente é possível observar os diferentes patossistemas atuando nas plantas de milho nos diferentes híbridos.

Entre os híbridos, P30F53 apresenta a maior média de NDVI, mas DKB390 não difere significativamente deste (tabela 13). A menor média de NDVI é observada no híbrido Fórmula. O genótipo 2B587 não difere deste híbrido e também do DKB390. Na média dos fungicidas, apesar de existir diferenças, estas são ainda muito seníveis. Apesar da Testemunha apresentar a menor média, esta não diferiu dos tratamentos Trifloxistrobina+Protioconazol, Fluxapiroxade+Piraclostrobina e do Controle Total. Os fungicidas Bixafen+Trifloxistrobina+Protioconazol e Benzovindiflupir+Azoxistrobina apesar das maiores médias, também não diferiram do Controle Total, Fluxapiroxade+Piraclostrobina e Trifloxistrobina+Protioconazol. Apesar das sensíveis diferenças observadas, ainda não é possível observar uma tendência clara entre os tratamentos fungicidas testados quanto as leituras de NDVI.

Em R3, momento no qual já se passaram todas as aplicações fungicidas, com exceção o Controle Total, a análise de variância mostra haver interação significativa entre os fatores híbridos (A) e fungicidas (B) para a variável NDVI (Apêndices 2 e 4). Na média dos híbridos, DKB390 tem a maior média de NDVI, mas que não difere do 2B587 (tabela 13). Este por sua vez tem média similar a P30F53. Fórmula, significativamente distinto dos demais tem a menor média de NDVI nesta avaliação. É a partir desta avaliação, em R3, estádio fenológico grão pastoso, que as leituras de NDVI começam a melhor detectar os diferentes patossistemas estudados atuando nos diferentes tratamentos. Mas, é nos tratamentos Testemunhas em que o sensor melhor detecta as diferenças entre NDVI. Na média dos fungicidas, o tratamento Testemunha obteve a menor média de NDVI entre todos os tratamentos. Portanto, todos os tratamentos diferiram estatisticamente da Testemunha, sem aplicação fungicida. O Controle Total obteve a maior média de NDVI em R3, mas os fungicidas Bixafen+Trifloxistrobina+Protioconazol, Fluxapiroxade+Piraclostrobina $\mathrm{e}$ Trifloxistrobina+Protioconazol também não diferiram deste. $\mathrm{O}$ fungicida Benzovindiflupir+Azoxistrobina, apesar da menor média de NDVI, não diferiu destes três últimos fungicidas. Segundo Berdugo et al. (2012) o fungicida Bixafen pode manter a área foliar verde por mais tempo em plantas de trigo e, com isso, favorecer para um maior enchimento de grãos e retardar a senescência foliar. Com exceção ao híbrido Fórmula em que a Testemunha se diferenciou significativamente dos demais tratamentos com, nos outros 
híbridos não há ainda uma diferenciação significativa, apesar de menores valores de NDVI neste tratamento.

É no estádio R5, última avaliação de NDVI, em que se pode perceber uma melhor distinção dos tratamentos em relação as leituras de NDVI (tabela 13). Percebe-se nitidamente as Testemunhas mais afetadas com as várias doenças que ocorreram durante o ciclo da cultura do milho no ensaio. Nesta avaliação, assim como ocorreu em R3, a análise de variância mostrou o mesmo comportamento com a interação significativa entre os fatores híbridos e fungicidas (Apêndices 2 e 4). É no estádio R5 das plantas de milho, antecedendo o período de maturação fisiológica da cultura, no qual se teve uma resposta final do NDVI para as diferenças entre todos os tratamentos do ensaio. Entre os híbridos, a maior média de NDVI é do híbrido P30F53, mas que, não diferiu do 2B587. O DKB390 mostrou-se similar a este, não diferindo significativamente. Já o Fórmula apresentou a menor média de NDVI entre os híbridos. Ao analisarmos as médias dos tratamentos fungicidas, todos os tratamentos diferenciaram-se estatisticamente em relação à Testemunha, com a menor média de NDVI. O Controle Total obteve a maior média de NDVI. O fungicida Bixafen+Trifloxistrobina+Protioconazol obteve comportamento similar ao Controle Total, não diferindo deste. Por sua vez, Fluxapiroxade+Piraclostrobina não diferiu de Bixafen+Trifloxistrobina+Protioconazol, com aos maiores valores de NDVI entre os fungicidas, sem levarmos em consideração o Controle Total. A mistura formulada triazól + estrobilurina Trifloxistrobina+Protioconazol apresentou comportamento similar a Benzovindiflupir+Azoxistrobina, inferiores as demais misturas contendo carboxamidas e superiores à Testemunha.

Ao compararmos apenas os tratamentos Testemunhas de cada híbrido, apenas no híbrido Fórmula, com o menor NDVI, esta se diferenciou estatisticamente dos demais. Em DKB390, P30F53 e 2B587 os tratamentos Testemunhas não diferiram entre si. O híbrido Fórmula foi o mais afetado com as doenças mancha-branca e cercosporiose, doenças estas com as maiores severidades entre todos os patossistemas avaliados no ensaio. Fato este que pode certamente ter contribuído para que suas Testemunhas apresentassem os menores valores de NDVI, afetado diretamente pelas maiores severidades das doenças mencionadas. No híbrido DKB390, com exceção à Testemunha com o menor NDVI, todos os demais tratamentos não diferiram entre si quanto os valores de NDVI. Ao analisar as médias dos tratamentos fungicidas no híbrido 2B587, verifica-se que apenas o Controle Total e Fluxapiroxade+Piraclostrobina diferiram estatisticamente da Testemunha. Foi neste híbrido em que a Testemunha menos se diferenciou dos demais tratamentos. 
Ao analisar os patossistemas ocorridos no ensaio, o híbrido 2B587 é um dos menos afetado com as doenças mancha-branca e cercosporiose. 
Tabela 13. Índice de vegetação por diferença normalizada (NDVI) da cultura do milho em diferentes estádios fenológicos em função de híbridos de milho e da aplicação de diferentes tratamentos fungicidas. Planaltina/DF, 2014.

\begin{tabular}{|c|c|c|c|c|c|c|c|c|}
\hline & \multirow{2}{*}{ Híbrido } & \multicolumn{6}{|c|}{ Fungicida** } & \multirow{2}{*}{ Média } \\
\hline & & 1 & 2 & 3 & 4 & 5 & 6 & \\
\hline \multirow{6}{*}{$\mathrm{V}^{2}$} & DKB 390 & $0.750^{1} \mathrm{Aa}^{*}$ & $0.750 \mathrm{abA}$ & $0.750 \mathrm{abA}$ & $0.752 \mathrm{aA}$ & $0.747 \mathrm{abA}$ & $0.752 \mathrm{aA}$ & $0.750 \mathrm{a}$ \\
\hline & P30F53 & $0.730 \mathrm{aA}$ & $0.722 \mathrm{cA}$ & $0.722 \mathrm{cA}$ & $0.717 \mathrm{bA}$ & $0.727 \mathrm{bA}$ & $0.720 \mathrm{bA}$ & $0.723 b$ \\
\hline & FÓRMULA & $0.745 \mathrm{aA}$ & $0.727 \mathrm{bcAB}$ & $0.730 \mathrm{bcAB}$ & $0.712 \mathrm{bB}$ & $0.727 \mathrm{bAB}$ & $0.722 \mathrm{bAB}$ & $0.727 \mathrm{~b}$ \\
\hline & 2B587 & $0.745 \mathrm{aA}$ & $0.752 \mathrm{aA}$ & $0.765 \mathrm{aA}$ & $0.760 \mathrm{aA}$ & $0.760 \mathrm{aA}$ & $0.750 \mathrm{aA}$ & $0.755 \mathrm{a}$ \\
\hline & Média & $0.742 \mathrm{~A}$ & $0.738 \mathrm{~A}$ & $0.741 \mathrm{~A}$ & $0.735 \mathrm{~A}$ & $0.740 \mathrm{~A}$ & $0.736 \mathrm{~A}$ & \\
\hline & & & CV $(\%)$ Híbridos & 1.68 & CV(\%) Fungicidas & 1.69 & Média Geral & 0.739 \\
\hline \multirow{6}{*}{$\mathrm{VT}^{3}$} & DKB 390 & $0.695^{1} \mathrm{aA}^{*}$ & $0.707 \mathrm{abA}$ & $0.717 \mathrm{aA}$ & $0.717 \mathrm{aA}$ & $0.702 \mathrm{aA}$ & $0.705 \mathrm{aA}$ & $0.707 \mathrm{ab}$ \\
\hline & P30F53 & $0.695 \mathrm{aB}$ & $0.717 \mathrm{aAB}$ & $0.72 \mathrm{aA}$ & $0.715 \mathrm{aAB}$ & $0.707 \mathrm{aAB}$ & $0.71 \mathrm{aAB}$ & $0.710 \mathrm{a}$ \\
\hline & FÓRMULA & $0.695 \mathrm{aA}$ & $0.687 \mathrm{bA}$ & $0.692 \mathrm{bA}$ & $0.692 \mathrm{bA}$ & $0.692 \mathrm{aA}$ & $0.7 \mathrm{aA}$ & $0.693 \mathrm{c}$ \\
\hline & 2B587 & $0.692 \mathrm{aA}$ & $0.7 \mathrm{abA}$ & $0.705 \mathrm{abA}$ & $0.71 \mathrm{abA}$ & $0.695 \mathrm{aA}$ & $0.705 \mathrm{aA}$ & $0.701 \mathrm{bc}$ \\
\hline & Média & $0.694 \mathrm{~B}$ & $0.703 \mathrm{AB}$ & $0.708 \mathrm{~A}$ & $0.708 \mathrm{~A}$ & $0.699 \mathrm{AB}$ & $0.705 \mathrm{AB}$ & \\
\hline & & & CV $(\%)$ Híbridos & 1.44 & CV(\%) Fungicidas & 1.58 & Média Geral & 0.703 \\
\hline \multirow{6}{*}{$\mathrm{R} 3^{4}$} & DKB 390 & $0.63^{1} \mathrm{aB}^{*}$ & $0.665 \mathrm{aA}$ & $0.665 \mathrm{aA}$ & $0.667 \mathrm{aA}$ & $0.662 \mathrm{aA}$ & $0.665 \mathrm{aA}$ & $0.659 \mathrm{a}$ \\
\hline & P30F53 & $0.635 \mathrm{aB}$ & $0.652 \mathrm{aAB}$ & $0.657 \mathrm{aAB}$ & $0.66 \mathrm{aAB}$ & $0.657 \mathrm{aAB}$ & $0.667 \mathrm{aA}$ & $0.655 \mathrm{ab}$ \\
\hline & FÓRMULA & $0.537 \mathrm{bD}$ & $0.605 \mathrm{bBC}$ & $0.58 \mathrm{bC}$ & $0.615 \mathrm{bAB}$ & $0.612 \mathrm{bAB}$ & $0.632 \mathrm{bA}$ & $0.597 \mathrm{c}$ \\
\hline & 2B587 & $0.642 \mathrm{aA}$ & $0.655 \mathrm{aA}$ & $0.652 \mathrm{aA}$ & $0.655 \mathrm{aA}$ & $0.642 \mathrm{aA}$ & $0.655 \mathrm{aA}$ & $0.650 \mathrm{~b}$ \\
\hline & Média & $0.611 \mathrm{C}$ & $0.644 \mathrm{AB}$ & $0.638 \mathrm{~B}$ & $0.649 \mathrm{AB}$ & $0.643 \mathrm{AB}$ & $0.655 \mathrm{~A}$ & \\
\hline & & & CV(\%) Híbridos & 1.16 & CV(\%) Fungicidas & 1.95 & Média Geral & 0.640 \\
\hline \multirow{6}{*}{$\mathrm{R} 5^{5}$} & DKB 390 & $0.560^{1} \mathrm{aB}^{*}$ & $0.600 \mathrm{aA}$ & $0.597 \mathrm{aA}$ & $0.607 \mathrm{aA}$ & $0.595 \mathrm{aA}$ & $0.607 \mathrm{abA}$ & $0.594 \mathrm{~b}$ \\
\hline & P30F53 & $0.562 \mathrm{aC}$ & $0.627 \mathrm{aAB}$ & $0.595 \mathrm{aBC}$ & $0.627 \mathrm{aAB}$ & $0.620 \mathrm{aAB}$ & $0.635 \mathrm{aA}$ & $0.611 \mathrm{a}$ \\
\hline & FÓRMULA & $0.347 \mathrm{bE}$ & $0.532 \mathrm{bBC}$ & $0.470 \mathrm{bD}$ & $0.542 \mathrm{bB}$ & $0.500 \mathrm{bCD}$ & $0.577 \mathrm{bA}$ & $0.495 \mathrm{c}$ \\
\hline & 2B587 & $0.580 \mathrm{aC}$ & $0.617 \mathrm{aAB}$ & $0.585 \mathrm{aBC}$ & $0.607 \mathrm{aABC}$ & $0.590 \mathrm{aBC}$ & $0.632 \mathrm{aA}$ & $0.602 \mathrm{ab}$ \\
\hline & Média & $0.512 \mathrm{D}$ & $0.594 \mathrm{~B}$ & $0.561 \mathrm{C}$ & $0.596 \mathrm{AB}$ & $0.576 \mathrm{C}$ & $0.613 \mathrm{~A}$ & \\
\hline & & & CV $(\%)$ Híbridos & 2.66 & CV(\%) Fungicidas & 2.84 & Média Geral & 0.575 \\
\hline
\end{tabular}

1 Índice de vegetação por diferença normalizada (NDVI); ${ }^{2} \mathrm{~V} 8=$ oito folhas de milho expandidas; ${ }^{3} \mathrm{VT}=$ emissão do pendão; ${ }^{4} \mathrm{R} 3=$ grão pastoso; ${ }^{5} \mathrm{R} 5=$ grão farináceo-duro; *Médias seguidas pela mesma letra, maiúscula na linha e minúscula na coluna, não diferem entre si pelo teste de Tukey (p $\leq 0,05)$. **Fungicidas: 1- Testemunha, 2- Fluxapiroxade + Piraclostrobina + Adjuvante $\left(50,1+99,9 \mathrm{~g}\right.$ i.a. ha $\left.{ }^{-1}+0,5 \% \mathrm{v} / \mathrm{v}\right), 3-$ Benzovindiflupir + Azoxistrobina + Adjuvante $\left(49,5+99 \mathrm{~g}\right.$ i.a. ha $\left.{ }^{-1}+0,5 \% \mathrm{v} / \mathrm{v}\right), 4-$ Bixafen $^{-}$Trifloxistrobina + Protioconazol + Adjuvante $\left(50+60+70\right.$ g i.a. ha $^{-1}+0,5 \%$ v/v), 5- Trifloxistrobina + Protioconazol + Adjuvante $\left(75+87,5\right.$ g i.a. ha ${ }^{-1}+0,5 \%$ v/v $), 6-$ Controle Total. 
Ao se observar a relação entre os valores de NDVI e os dados de AACPD das doenças avaliadas no ensaio, percebe-se forte correlação negativa entre estas variáveis para a maioria das doenças. Para aqueles genótipos de milho mais sensíveis às doenças tem-se as maiores correlações com as leituras de NDVI conforme pode ser observado nas figuras 3, 4, 5 e 6 (tabelas 14, 15, 16 e 17). Em todos os híbridos é possível observar a linearidade entre os valores de NDVI e AACPD para todas as doenças.

Ao analisar as figuras com a dispersão dos valores de NDVI e AACPD, observa-se alguns valores mais distantes da reta, mas há sempre a tendência de que os maiores valores de AACPD são acompanhados pelas menores leituras de NDVI. Nota-se claramente a sensibilidade do NDVI a fatores bióticos como a ação dos patógenos estudados.

Dentre os patógenos avaliados, os necrotróficos mostraram-se mais determinantes para reduções nos valores de NDVI obtidos nas avaliações da cultura do milho no presente estudo. Porém é válido ressaltar que tais resultados são inerentes as condições ambientais, híbridos de milho e patógenos ocorridos neste estudo.

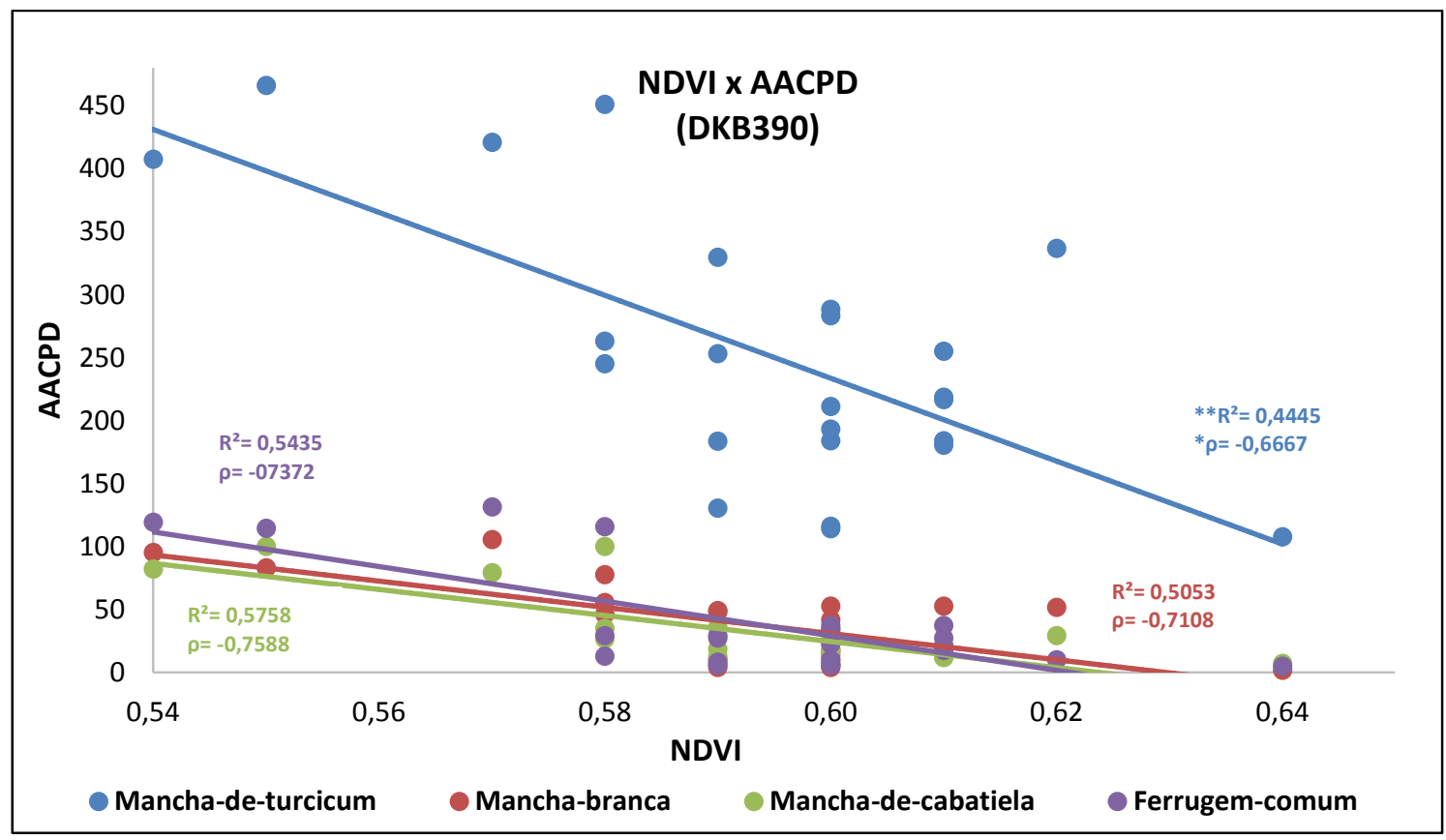

Figura 2. Dispersão entre os valores de Índice de vegetação por diferença normalizada (NDVI) e Ârea abaixo da curva de progresso das doenças (AACPD) mancha-de-turcicum (Exserohilum turcicum), ferrugem-comum (Puccinia sorghi), mancha-de-cabatiela (Kabatiella zeae) e mancha-branca (Phaeosphaeria maydis/Pantoea ananatis) no estádio R5 do híbrido de milho DKB390. *Coeficiente de correlação linear de Pearson; **Fator de determinação. Valores significativos ao nível de $1 \%$ de probabilidade $(\mathrm{p}<0,01)$. 


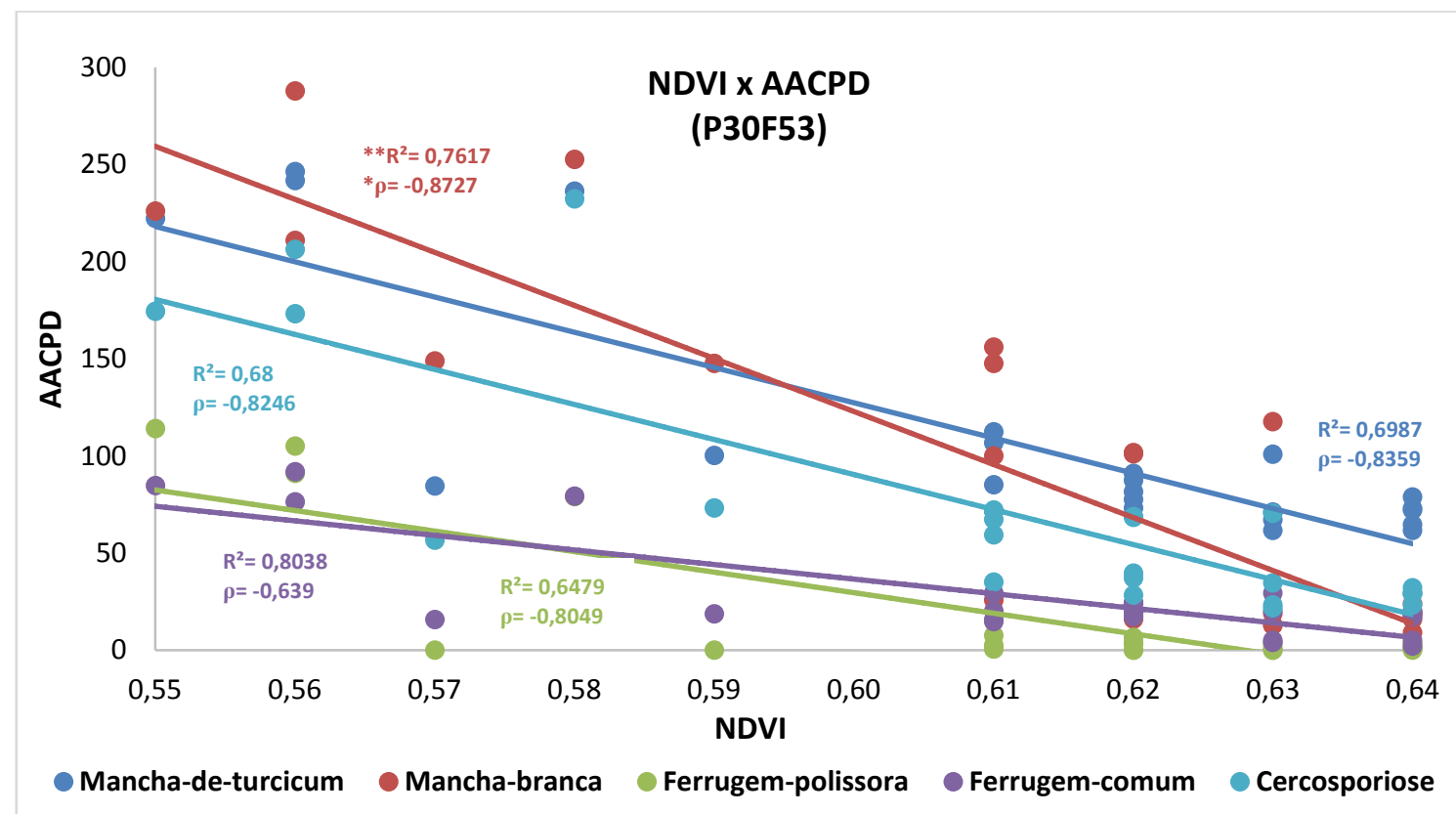

Figura 3. Dispersão entre os valores de Índice de vegetação por diferença normalizada (NDVI) e Área abaixo da curva de progresso das doenças (AACPD) mancha-de-turcicum (Exserohilum turcicum), ferrugem-comum (Puccinia sorghi), ferrugem-polissora (Puccinia polysora), mancha-branca (Phaeosphaeria maydis/Pantoea ananatis) e cercosporiose (Cercospora zeaemaydis) no estádio R5 do híbrido de milho P30F53. *Coeficiente de correlação linear de Pearson; **Fator de determinação. Valores significativos ao nível de $1 \%$ de probabilidade $(\mathrm{p}<0,01)$.

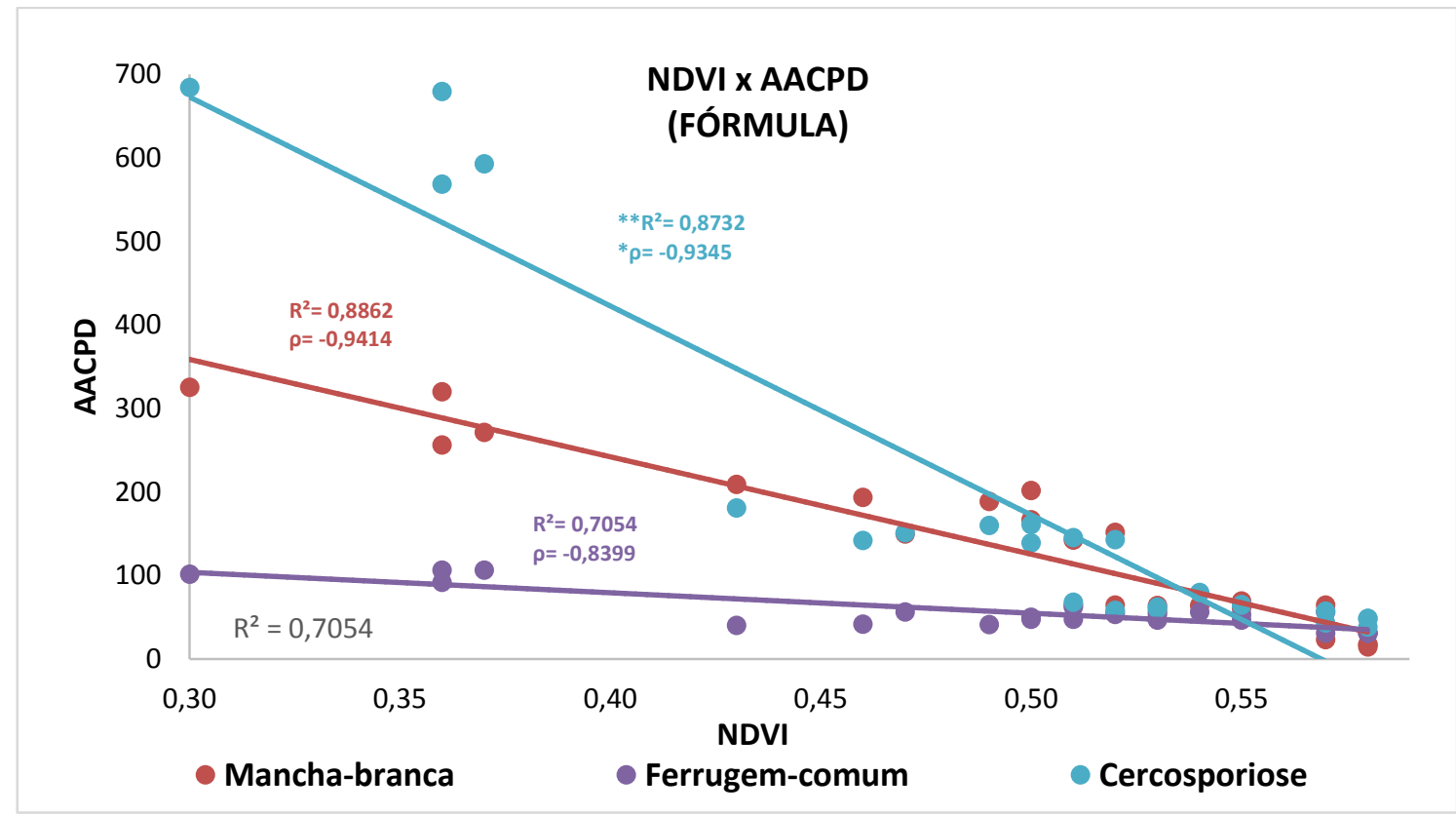

Figura 4. Dispersão entre os valores de Índice de vegetação por diferença normalizada (NDVI) e Área abaixo da curva de progresso das doenças (AACPD) ferrugem-comum (Puccinia sorghi), mancha-branca (Phaeosphaeria maydis/Pantoea ananatis) e cercosporiose (Cercospora zeae-maydis) no estádio R5 do híbrido de milho Fórmula. *Coeficiente de correlação linear de Pearson; **Fator de determinação. Valores significativos ao nível de $1 \%$ de probabilidade $(\mathrm{p}<0,01)$. 


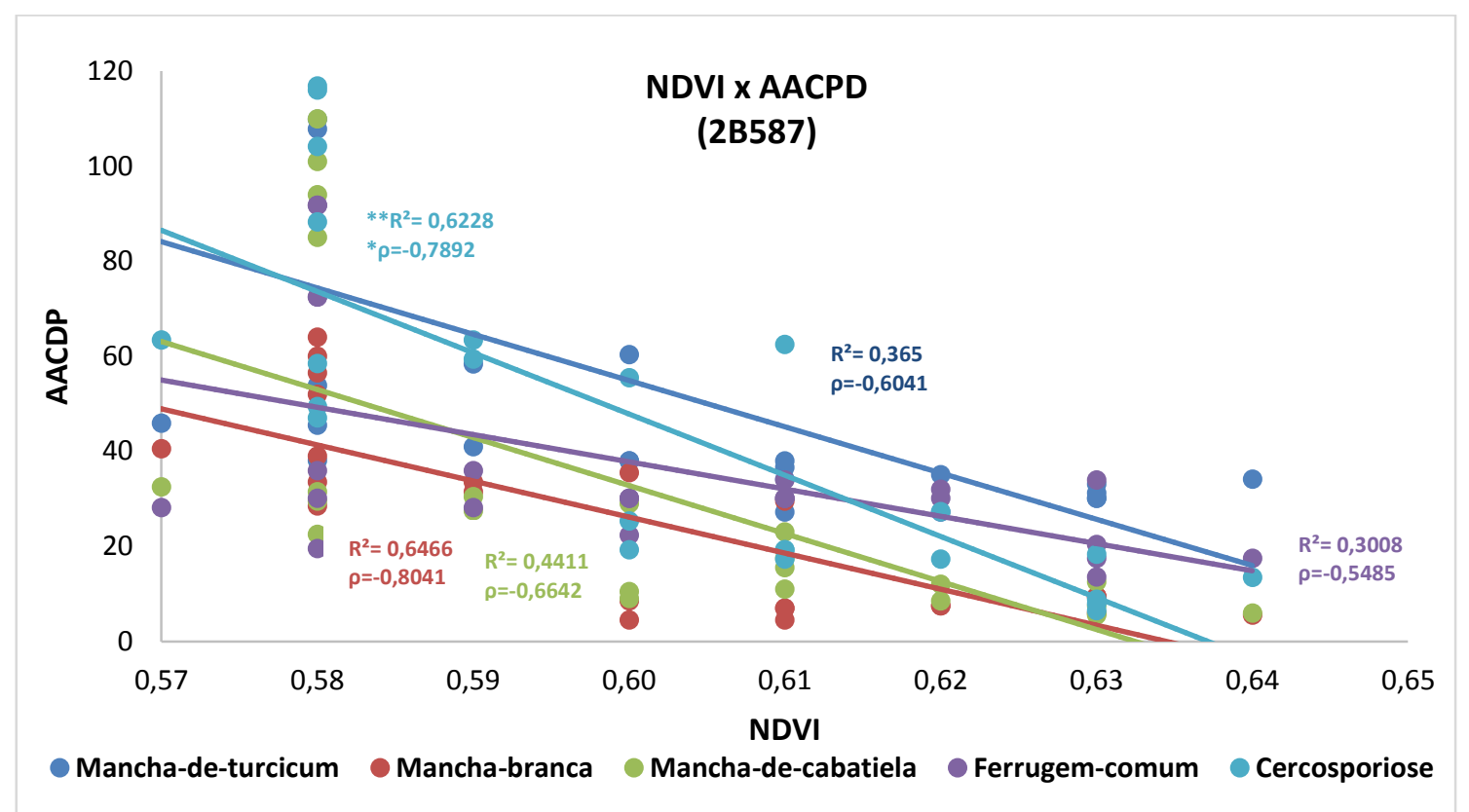

Figura 5. Dispersão entre os valores de Índice de vegetação por diferença normalizada (NDVI) e Área abaixo da curva de progresso das doenças (AACPD) mancha-de-turcicum (Exserohilum turcicum), ferrugem-comum (Puccinia sorghi), mancha-de-cabatiela (Kabatiella zeae), mancha-branca (Phaeosphaeria maydis/Pantoea ananatis) e cercosporiose (Cercospora zeaemaydis) no estádio R5 do híbrido de milho 2B587. *Coeficiente de correlação linear de Pearson; **Fator de determinação. Valores significativos ao nível de $1 \%$ de probabilidade $(\mathrm{p}<0,01)$.

A dispersão entre os valores de NDVI e produtividade de grãos, mostraram a tendência dos maiores valores de produtividade relacionados com as maiores leituras de NDVI. Plantas de milho mais sadias, com maiores valores NDVI resultaram em maior potencial de rendimento da cultura. Segundo Shanahan et al. (2001), o NDVI em milho atinge um pico no pendoamento, no entanto, é durante meados do período de enchimento de grãos que as leituras de NDVI mostraram melhor se correlacionar com o rendimento final do milho. Este período mostrou-se o melhor para a estimativa do potencial de rendimento da cultura.

Grohs et al. (2009) trabalhando com as culturas de trigo e cevada, concluiram que o NDVI pode ser utilizado para estimativa do potencial produtivo destas culturas. Avaliando a estimativa da produtividade com leituras de NDVI, Rudorff et al. (2003) observaram relação direta entre as duas variáveis apenas para produtividades até 5 mil $\mathrm{Kg}_{\text {.ha-1 }}$. Isaev (2012) trabalhando com a cultura do amendoim, obteve correlação positiva significativa entre NDVI e produtividade na maioria dos tratamentos avaliados. Tratamentos com as maiores severidades de doenças obtiveram as menores produtividades e menores valores de NDVI. Em estudos mais antigos já haviam sido relatados a correlação entre índices de vegetação e biomassa verde das plantas (GROTEN, 1993). 


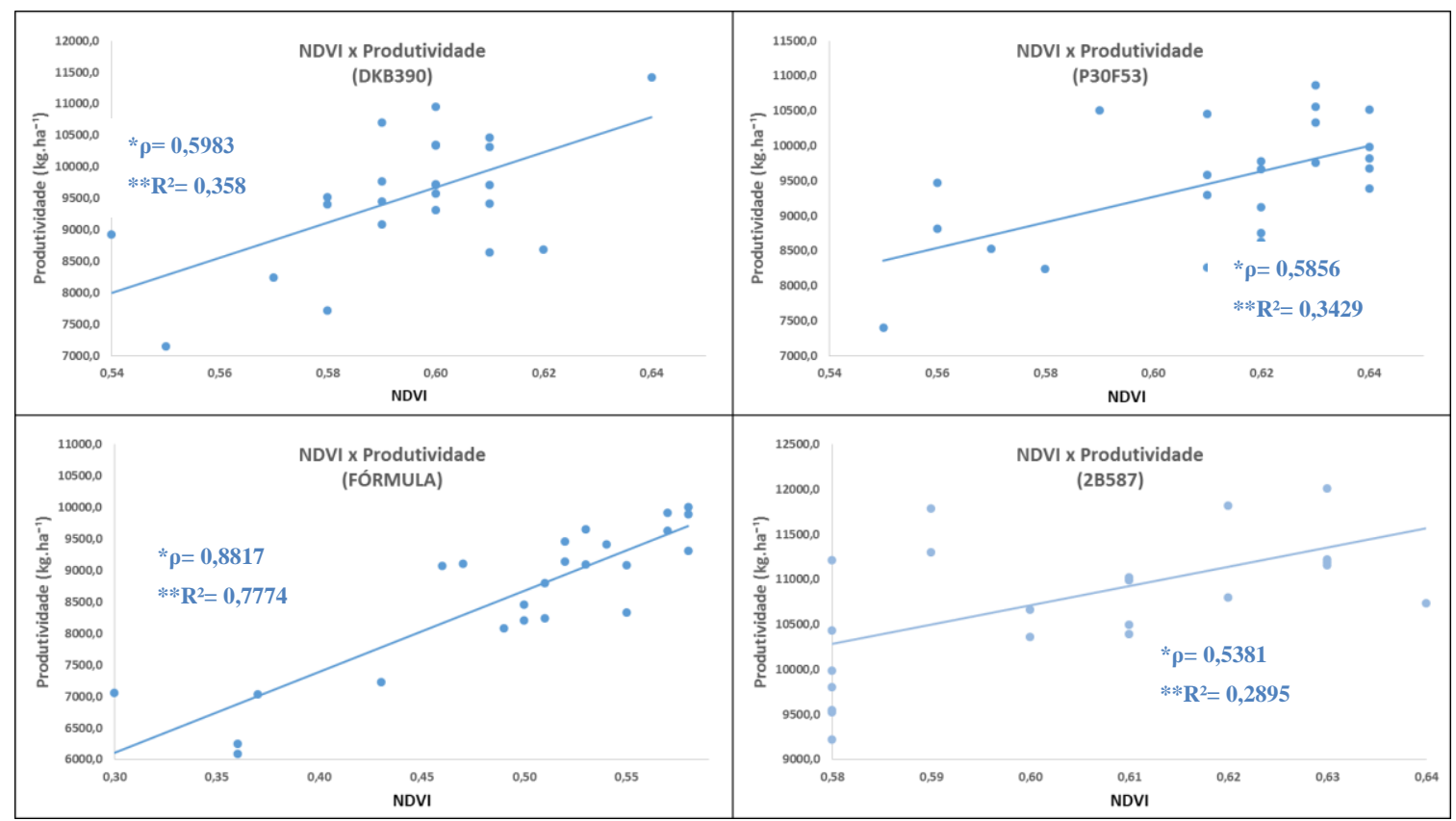

Figura 6. Dispersão entre os valores de NDVI no estádio R5 e produtividade de grãos dos híbridos de milho DKB390, P30F53, FÓRMULA e 2B587. *Coeficiente de correlação linear de Pearson; **Fator de determinação. Valores significativos ao nível de $1 \%$ de probabilidade $(\mathrm{p}<0,01)$.

\subsubsection{Correlação entre as variáveis}

A análise de correlação simples de Pearson entre as variáveis do presente trabalho objetiva mostrar a relação de linearidade entre as variáveis estudadas. Apesar de ser uma ferramenta estatística e não levar em consideração questões biológicas de difícil mensuração é ainda muito válido na tentativa de melhor elucidar os resultados obtidos e suas inter-relações. Estas estimativas de correlações são importantes uma vez que no campo é difícil isolar somente um patógeno para correlaciona-lo com outras variáveis.

Os coeficientes de correlação linear entre as variáveis produtividade e massa de mil grãos (MMG) para todos os híbridos apresentou correlação positiva significativa, tendo no híbrido Fórmula a correlação mais forte entre estas variáveis, acima de 80\% (tabelas 14, 15, 16 e 17). Estes resultados demonstram a clara tendência de que quanto maior os níveis de produtividade, maior foram os valores de MMG, mostrando uma boa linearidade entre estas duas variáveis. Esses resultados vão ao encontro daqueles encontrados por Ramos (2011) e Ottaviano e Camussi (1981), os quais também encontraram correlações positivas e fortes entre as variáveis massa de mil grãos e produtividade. No entanto, é importante ressaltar que esta correlação varia muito entre genótipos de milho, sendo uns mais sensíveis e outros nem tanto. 
Ainda, segundo Fader e Koller (1983) o enchimento de grãos é dependente da exportação de fotoassimilados das folhas aos grãos. Logo, tudo que pode afetar negativamente a área foliar fotossinteticamente ativa das plantas de milho, impactarão na massa de mil grãos e por consequência a produtividade final de grãos milho.

Analisando produtividade versus AACPD das doenças avaliadas, as correlações foram negativas e significativas para todos os patossistemas ocorrentes. As fortes correlações apresentadas entre estas duas variáveis dão ideia do quanto a área foliar sadia em plantas de milho reflete na produtividade. As correlações foram mais fortes nos híbridos Fórmula, DKB390 e 2B587, enquanto que no P30F53 foi moderada. Os maiores valores foram para a AACPD de cercosporiose e mancha-branca no híbrido Fórmula, com 85,6\% e 84,8\% de correlação negativa com a produtividade, respectivamente. Logo, neste híbrido a cercosporiose e a mancha-branca foram as principais responsáveis pela redução de produtividade. Brito (2010) também encontrou fortes correlações entre AACPD das doenças mancha-branca e cercosporiose com a produtividade de grãos em alguns locais de Minas Gerais. No híbrido DKB390 a maior correlação entre produtividade e AACPD foi com a mancha-de-turcicum, tendo 80,6\% de correlação, indicando que neste genótipo a mancha-de-turcicum pode ter sido a principal doença a impactar na produtividade. No Fórmula, segundo a análise de correlação, a cercosporiose é a doença que mais influenciou na produtividade, com 85,6\%, apesar de que a mancha-branca não foi muito abaixo, com $84,8 \%$ de correlação. Tem-se neste caso dois patógenos atuando fortemente sobre o mesmo híbrido e com impactos negativos na produtividade muito semelhantes. No híbrido 2B587, não se observa claramente uma doença atuando mais sobre outra na produtividade, já que, pela análise de correlação, todas as doenças tiveram sua AACPD se correlacionando com a produtividade entre $61 \%$ e $69 \%$. Comportamento semelhante ocorreu com o híbrido P30F53, no qual estas mesmas correlações ficaram entre $51 \%$ e 54\%. Logo, pela análise de correlação entre produtividade e AACPD não há um predomínio claro de uma doença influenciando mais que outra nesta variável de rendimento de grãos de milho nestes dois últimos híbridos.

Ao analisar a correlação existente entre o componente de rendimento massa de mil grãos e AACPD, observa-se para todos os híbridos uma forte correlação negativa e significativa para todas as doenças avaliadas. É interessante observar que naqueles híbridos nos quais a correlação com produtividade foi menos forte, como nos híbridos P30F53 e 2B587, agora com o componente MMG, esta correlação mostrou-se mais forte, com um mínimo de $88 \%$ (manchabranca em 2B587) e o máximo de 97\% (mancha-de-turcicum em P30F53). Isto mostra que as 
doenças nestes dois genótipos influenciaram mais na variável massa de mil grãos do que na produtividade final destes dois híbridos. Para os híbridos Fórmula e DKB390 a correlação das doenças com MMG mostrou-se ainda mais forte do que já era com a produtividade. Nestes, pôde ser observada correlação de até $98 \%$ como a existente entre a AACPD da cercosporiose e MMG no híbrido Fórmula.

A correlação entre incidência de grãos ardidos e AACPD para as diversas doenças, com exceção ao híbrido 2B587, todos os demais apresentaram forte correlação positiva e significativa, indicando que quanto mais doentes as plantas estavam, mais suscetíveis à ocorrência de grãos ardidos estas estão. Mesmo que as doenças foliares estudadas não são ocasionadas pelos mesmos patógenos responsáveis por grãos ardidos, plantas mais debilitadas por doenças foliares também ficam mais suscetíveis a doenças de colmo e espigas. No híbrido 2B587, o mais tolerante às doenças foliares estudadas entre os híbridos deste ensaio, apresentou correlações mais fracas e até não significativa como para mancha-de-turcium. Esta correlação mostrou que as doenças foliares avaliadas não influenciaram tanto quanto nos outros híbridos a ocorrência de grãos ardidos.

Quanto correlação entre AACPD das doenças foliares e Fusarium sp. nos grãos de milho, nos híbridos P30F53 e 2B587 as correlações foram positivas significativas de moderadas a fortes. Nos híbridos Fórmula e DKB390 os valores de correlação, quando significativas, foram em geral moderadas a fracas.

Entre AACPD e NDVI, a análise de correlação simples entre as variáveis apontou haver correlação negativa significativa para todas as doenças em todos os híbridos. No híbrido Fórmula há correlação muito forte do NDVI com AACPD de cercosporiose e manha-branca, e forte com ferrugem-comum. No híbrido P30F53 o NDVI correlacionou-se fortemente com AACPD de todas as doenças avaliadas, cercosporiose, ferrugem-comum, ferrugem-polissora, mancha-branca e mancha-de-turcicum. No DKB390 a correlação também foi forte com as doenças ferrugem-comum, mancha-de-cabatiela, mancha-branca e mancha-de-turcicum. Já no híbrido 2B587, com exceção as AACPD de ferrugem-comum, moderada, para as demais doenças, cercosporiose, mancha-de-cabatiela e mancha-branca a análise de correlação apontou ser forte. Como o índice NDVI dá uma ideia do estado sanitário das plantas, percebe-se que os resultados de sua correlação com as doenças ocorrentes nos diferentes híbridos, vão ao encontro do que se observou visualmente a campo nos diferentes tratamentos. Quanto menor o NDVI, maior é a severidade de um ou mais patossistemas atuando num determinado grupo de plantas. Godoy e Henning (2008) encontraram alta correlação do NDVI com a produtividade e 
severidade da ferrugem-asiática na cultura da soja. Ainda, segundo Tucker (1979) o NDVI se correlaciona com variáveis biofísicas importantes como massa foliar verde, área foliar verde, conteúdo de água nas folhas e quantidade total de clorofila. Esta informação, do ponto de vista fitopatológico vem ao encontro dos dados obtidos neste estudo já que onde se teve as menores AACPDs tem-se as maiores leituras de NDVI.

A análise de correlação entre as AACPD dos diferentes patossistemas nos diferentes híbridos foram todas positivas significativas e fortes. Em princípio nenhuma doença agiu de forma a inibir o estabelecimento e desenvolvimento de outra.

A relação da produtividade com NDVI foi positiva variando de 53,8\% no híbrido 2B587 a $88,1 \%$ no híbrido Fórmula. Pode-se afirmar com base na sanidade destes dois híbridos que na medida em que se tem um genótipo mais sensível as doenças, mais facilmente isso pode ser detectado pelos valores de NDVI, como o que ocorreu com o Fórmula. Na medida em que se tem maiores os valores de NDVI, tem as maiores produtividades. Povh et al. (2008) trabalhando com as culturas do milho, trigo, cevada e triticale, encontrou alta correlação entre as variáveis NDVI e produtividade, corroborando com os dados obtidos no presente estudo. Na mesma linha, Ma et al. (2001) e Antuniassi et al. (2007) também confirmam a existência de correlação positiva entre a reflectância do dossel das plantas (NDVI) e a produtividade das culturas. Teal et al. (2006) estimaram com sucesso o potencial de rendimento de grãos de milho com o uso do sensor remoto GreenSeeker®.

Ainda, a análise entre produtividade e grãos ardidos, mostrou haver forte correlação negativa significativa para os híbridos Fórmula e DKB390, e moderada para os híbridos P30F53 e 2B587. Já com a incidência de Fusarium verticillioides em grãos, a correlação com a produtividade foi negativa significativa mas moderada. No híbrido DKB390 não foi significativa.

Para NDVI e MMG a correlação mostrou-se positiva significativa e forte em todos os híbridos, sendo que nos híbridos Fórmula e P30F53 esta correlação foi de 92,7\% e 84,5\%, respectivamente. Na medida em que se tem plantas mais "verdes" ou com maior área foliar fotossinteticamente ativa, tem se maior capacidade para de enchimento de grãos, ou seja, maior massa de mil grãos. É interessante observar que este mesmo comportamento nestes híbridos ocorreu entre NDVI e porcentagem de grãos ardidos. Nos híbridos Fórmula e P30F53 tem se a correlação de $91,4 \%$ e $80,6 \%$ entre NDVI e incidência de grãos ardidos. Já NDVI com a incidência de Fusarium sp. tem se correlação negativa significativa moderada em todos os híbridos. 
Entre Fusarium sp. e grãos ardidos a análise de correlação mostra-se positiva significativa mas moderada. Os valores de uma variável nem sempre acompanham a outra com a mesma intensidade e também, outros fatores bióticos ou abióticos podem ter contribuído para a ocorrência de grãos ardidos. Outra explicação é que fungos do gênero Fusarium podem infectar a planta sem causar sintomas, como pode ser comprovado pelos resultados obtidos no experimento no qual se tem híbridos com alta incidência de Fusarium sp. nos grãos, mas que não se refletiu totalmente em grãos ardidos. Já entre MMG e porcentagem de grãos ardidos, a correlação é negativa significativa e forte para os híbridos DKB390, P30F53 e Fórmula. Já para 2B587 correlação entre estas variáveis é moderada. As maiores incidências de grãos ardidos afetaram negativamente a massa de mil grãos.

Tabela 14. Coeficiente de correlação linear de Pearson entre as variáveis produtividade de grãos (Prod.), massa de mil grãos (MMG), área abaixo da curva de progresso das doenças ferrugem-comum (AACPFc), mancha-de-cabatiela (AACPMc), mancha-branca (AACPMb) e mancha-de-turcicum (AACPMt), incidência de grãos ardidos (\%), incidência de Fusarium verticillidoides em grãos (\%) e índice de vegetação por diferença normalizada (NDVI) no híbrido de milho DKB390. Planaltina/DF, 2014.

\begin{tabular}{|c|c|c|c|c|c|c|c|c|c|}
\hline & Prod & MMG & G.ardidos & Fusarium & $\mathrm{NDVI}^{1}$ & AACPFC & AACPMC & AACPMb & AACPMt \\
\hline \multirow{2}{*}{ Prod. } & \multirow{4}{*}{1} & \multirow{4}{*}{$\begin{array}{c}0.7701^{* *} \\
1\end{array}$} & - & & \multirow{3}{*}{$0.5983^{* *}$} & - & - & - & - \\
\hline & & & $0.6477^{* *}$ & -0.3517 & & $0.6686^{* *}$ & $0.7846 * *$ & $0.7471^{* *}$ & $0.8061^{* *}$ \\
\hline \multirow{2}{*}{ MMG } & & & - & - & & - & - & - & - \\
\hline & & & $0.7776^{* *}$ & $0.5705^{* *}$ & $0.691 * *$ & $0.8902 * *$ & $0.9167^{* *}$ & $0.7982^{* *}$ & $0.8582^{* *}$ \\
\hline $\begin{array}{c}\text { G.ardido } \\
\mathrm{s}\end{array}$ & & & 1 & 0.3987 & $-0.5137^{*}$ & $0.7455^{* *}$ & $0.8326 * *$ & $0.8436 * *$ & $0.8424 * *$ \\
\hline Fusarium & & & & 1 & $-0.4253^{*}$ & $0.6751 * *$ & $0.504 *$ & $0.4511^{*}$ & 0.3998 \\
\hline \multirow{2}{*}{$N D V I^{1}$} & & & & & \multirow[t]{2}{*}{1} & - & & & \\
\hline & & & & & & $0.7372^{* *}$ & $0.7588^{* *}$ & $0.7108^{* *}$ & $0.6667^{* *}$ \\
\hline AACPFC & & & & & & 1 & $0.9083^{* *}$ & $0.811^{* *}$ & $0.8075^{* *}$ \\
\hline AACPMC & & & & & & & 1 & $0.8626^{* *}$ & $0.9206 * *$ \\
\hline AACPMb & & & & & & & & 1 & $0.9319 * *$ \\
\hline AACPMt & & & & & & & & & 1 \\
\hline
\end{tabular}

**Significativo ao nível de $1 \%$ de probabilidade $(\mathrm{p}<0,01)$; *Significativo ao nível de $5 \%$ de probabilidade $(\mathrm{p} \leq 0,05) ;{ }^{1} \mathrm{NDVI}$ no estádio fenológico de grão farináceo-duro (R5). 
Tabela 15. Coeficiente de correlação linear de Pearson entre as variáveis produtividade de grãos (Prod.), massa de mil grãos (MMG), área abaixo da curva de progresso das doenças cercosporiose (AACPC), ferrugem-comum (AACPFc), ferrugem-polissora (AACPFp), mancha-branca (AACPMb) e mancha-de-turcicum (AACPMt), incidência de grãos ardidos (\%), incidência de Fusarium verticillidoides em grãos (\%) e índice de vegetação por diferença normalizada (NDVI) no híbrido de milho P30F53. Planaltina/DF, 2014.

\begin{tabular}{|c|c|c|c|c|c|c|c|c|c|c|}
\hline & Prod. & MMG & G.ardidos & Fusarium & $\mathrm{NDVI}^{1}$ & AACPC & AACPFC & AACPFp & AACPMb & AACPMt \\
\hline Prod. & 1 & $0.5964 * *$ & $-0.5518 * *$ & $-0.4522 *$ & $0.5856 * *$ & $-0.5293 * *$ & $-0.5452 * *$ & $-0.5471 * *$ & $-0.5113^{*}$ & $-0.5239 * *$ \\
\hline MMG & & 1 & $-0.8672 * *$ & $-0.7276 * *$ & $0.8453^{* *}$ & $-0.9653 * *$ & $-0.9744 * *$ & $-0.9561 * *$ & $-0.8823 * *$ & $-0.973 * *$ \\
\hline G.ardidos & & & 1 & $0.5646^{* *}$ & $-0.8067^{* *}$ & $0.8996 * *$ & $0.8754^{* *}$ & $0.8604^{* *}$ & $0.8084^{* *}$ & $0.9014^{* *}$ \\
\hline Fusarium & & & & 1 & $-0.5762 * *$ & $0.6374 * *$ & $0.7693 * *$ & $0.6369 * *$ & $0.5289 * *$ & $0.628 * *$ \\
\hline $\mathrm{NDVI}^{1}$ & & & & & 1 & $-0.8246 * *$ & $-0.8038^{* *}$ & $-0.8049 * *$ & $-0.8727^{* *}$ & $-0.8359 * *$ \\
\hline AACPC & & & & & & 1 & $0.9468 * *$ & $0.9119 * *$ & $0.9219 * *$ & $0.9772 * *$ \\
\hline AACPFC & & & & & & & 1 & $0.9552^{* *}$ & $0.8241^{* *}$ & $0.9593^{* *}$ \\
\hline AACPFp & & & & & & & & 1 & $0.774 * *$ & $0.9589 * *$ \\
\hline AACPMb & & & & & & & & & 1 & $0.8892^{* *}$ \\
\hline AACPMt & & & & & & & & & & 1 \\
\hline
\end{tabular}

**Significativo ao nível de $1 \%$ de probabilidade $(\mathrm{p}<0,01)$; *Significativo ao nível de $5 \%$ de probabilidade $(\mathrm{p} \leq 0,05) ;{ }^{1} \mathrm{NDVI}$ no estádio fenológico de grão farináceo-duro (R5).

Tabela 16. Coeficiente de correlação linear de Pearson entre as variáveis produtividade de grãos (Prod.), massa de mil grãos (MMG), área abaixo da curva de progresso das doenças cercosporiose (AACPC), ferrugem-comum (AACPFc) e mancha-branca (AACPMb), incidência de grãos ardidos (\%), incidência de Fusarium verticillidoides em grãos (\%) e índice de vegetação por diferença normalizada (NDVI) no híbrido de milho Fórmula. Planaltina/DF, 2014.

\begin{tabular}{ccccccccc}
\hline & Prod. & MMG & G.ardidos & Fusarium & NDVI $^{1}$ & AACPC & AACPFc & AACPMb \\
\hline Prod. & 1 & $0.8586^{* *}$ & $-0.8615^{* *}$ & $-0.4414^{*}$ & $0.8817^{* *}$ & $-0.8568^{* *}$ & $-0.7594^{* *}$ & $-0.8481^{* *}$ \\
MMG & & 1 & $-0.8528^{* *}$ & $-0.4404^{*}$ & $0.9278^{* *}$ & $-0.9846^{* *}$ & $-0.9372^{* *}$ & $-0.8681^{* *}$ \\
G.ardidos & & & 1 & $0.4189^{*}$ & $-0.9141^{* *}$ & $0.8406^{* *}$ & $0.7678^{* *}$ & $0.9019^{* *}$ \\
Fusarium & & & & 1 & $-0.4463^{*}$ & $0.4226^{*}$ & $0.5269^{* *}$ & $0.4738^{*}$ \\
NDVI $^{1}$ & & & & & 1 & $-0.9345^{* *}$ & $-0.8399^{* *}$ & $-0.9414^{* *}$ \\
AACPC & & & & & & 1 & $0.892^{* *}$ & $0.8697^{* *}$ \\
AACPFC & & & & & & & 1 & $0.754^{* *}$ \\
AACPMb & & & & & & & & 1
\end{tabular}

**Significativo ao nível de $1 \%$ de probabilidade $(\mathrm{p}<0,01)$; *Significativo ao nível de $5 \%$ de probabilidade $(\mathrm{p} \leq 0,05) ;{ }^{1} \mathrm{NDVI}$ no estádio fenológico de grão farináceo-duro (R5). 
Tabela 17. Coeficiente de correlação linear de Pearson entre as variáveis produtividade de grãos (Prod.), massa de mil grãos (MMG), área abaixo da curva de progresso das doenças cercosporiose (AACPC), ferrugem-comum (AACPFc), mancha-de-cabatiela (AACPMc), mancha-branca (AACPMb) e mancha-de-turcicum (AACPMt), incidência de grãos ardidos (\%), incidência de Fusarium verticillidoides em grãos (\%) e índice de vegetação por diferença normalizada (NDVI) no híbrido de milho 2B587. Planaltina/DF, 2014.

\begin{tabular}{|c|c|c|c|c|c|c|c|c|c|c|}
\hline & Prod. & MMG & G.ardidos & Fusarium & $N D V l^{1}$ & AACPC & AACPFC & AACPMC & AACPMb & AACPMt \\
\hline Prod. & 1 & $0.6082^{* *}$ & $-0.5343 * *$ & $-0.573 * *$ & $0.5381^{* *}$ & $-0.6547^{* *}$ & $-0.6125^{* *}$ & $-0.6908^{* *}$ & $-0.66 * *$ & $-0.6134 * *$ \\
\hline MMG & & 1 & -0.3868 & $-0.8165^{* *}$ & $0.6972 * *$ & $-0.9413^{* *}$ & $-0.8807^{* *}$ & $-0.96 * *$ & $-0.908^{* *}$ & $-0.9349 * *$ \\
\hline G.ardidos & & & 1 & $0.4033^{*}$ & $-0.4883^{*}$ & $0.4744^{*}$ & $0.4791^{*}$ & $0.4728^{*}$ & $0.412^{*}$ & 0.3398 \\
\hline Fusarium & & & & 1 & $-0.4183^{*}$ & $0.7675^{* *}$ & $0.9288^{* *}$ & $0.9051 * *$ & $0.6847^{* *}$ & $0.8624 * *$ \\
\hline$N D V l^{1}$ & & & & & 1 & $-0.7892^{* *}$ & $-0.5485^{* *}$ & $-0.6642^{* *}$ & $-0.8041 * *$ & $-0.6041^{* *}$ \\
\hline AACPC & & & & & & 1 & $0.8333^{* *}$ & $0.9226^{* *}$ & $0.9584^{* *}$ & $0.8723^{* *}$ \\
\hline AACPFC & & & & & & & 1 & $0.9364^{* *}$ & $0.744^{* *}$ & $0.901 * *$ \\
\hline AACPMC & & & & & & & & 1 & $0.895^{* *}$ & $0.9587^{* *}$ \\
\hline AACPMb & & & & & & & & & 1 & $0.8736 * *$ \\
\hline AACPMt & & & & & & & & & & 1 \\
\hline
\end{tabular}

**Significativo ao nível de $1 \%$ de probabilidade (p<0,01); *Significativo ao nível de $5 \%$ de probabilidade ( $\mathrm{p} \leq 0,05) ;{ }^{1} \mathrm{NDVI}$ no estádio fenológico de grão farináceo-duro (R5).

\subsection{Experimento 2}

\subsection{1 Área abaixo da curva de progresso da doença (AACPD)}

Assim como no experimento 1, a análise de variância para a variável área abaixo da curva de progresso da doença (AACPD) mostrou haver interação significativa entre os fatores A (Híbridos) e B (Fungicidas) para todas as doenças estudadas (Apêndices 1 e 3).

Para a cercosporiose, o híbrido DKB390 foi o único em que a doença não foi avaliada (tabela 18). Já os demais híbridos apresentaram médias distintas significativamente sendo que, Fórmula foi o genótipo com a maior média de AACPC e 2B587 a menor. No experimento 2 a cercosporiose mostrou-se mais agressiva quando comparada ao experimento 1 e mais precocemente detectada nos tratamentos Testemunhas. Brito (2010) já relatara que quanto mais precocemente a doença fosse detectada, maiores são os danos em produtividade. Ao analisar o comportamento médio dos fungicidas em todos os híbridos pode-se visualizar que todos diferiram estatisticamente entre si e do tratamento Testemunha. Percebe-se uma grande variação no valor de médio de AACPC, sendo que a magnitude desta variação foi de 7,93 para o Controle Total e 298,81 para a Testemunha.

O comportamento dos fungicidas em ordem dos que mais controlaram a cercosporiose ao de menor controle tem-se Fluxapiroxade+Piraclostrobina, Bixafen+Trifloxistrobina+Protioconazol, Trifloxistrobina+Protioconazol e 
Benzovindiflupir+Azoxistrobina, respectivamente. Observando os valores de eficácia de controle da AACPC, no híbrido P30F53 apenas o tratamento Benzovindiflupir+Azoxistrobina obteve eficácia inferior a $80 \%$.

De forma geral, observa-se que Fluxapiroxade+Piraclostrobina e Bixafen+Trifloxistrobina+Protioconazol tiveram comportamento superior no controle da cercosporiose entre os fungicidas contendo carboxamida em sua constituição.

Em termos numéricos de eficácia de controle, estas apresentaram controle inferior apenas em relação ao Controle Total. No híbrido Fórmula observa-se que todos os tratamentos fungicidas diferiram significativamente um do outro, tendo Fluxapiroxade+Piraclostrobina provido o melhor controle da cercosporiose. Nos híbridos P30F53 e 2B587, com exceção aos tratamentos Controle Total e Testemunha, houve similaridade entre o comportamento dos fungicidas no controle de cercosporiose. Em tais híbridos, destacaram-se os fungicidas Fluxapiroxade+Piraclostrobina e Bixafen+Trifloxistrobina+Protioconazol, similares entre si e distintos dos demais.

Tabela 18. Área abaixo da curva de progresso da cercosporiose (Cercospora zeae-maydis) (AACPC) e eficácia de controle (\%) na cultura do milho (Zea mays) em função da aplicação de diferentes tratamentos fungicidas e híbridos de milho. Planaltina/DF, 2014.

\begin{tabular}{|c|c|c|c|c|c|c|c|c|c|c|c|c|c|c|}
\hline \multirow{2}{*}{$\frac{\text { Fung.** }}{1}$} & \multicolumn{2}{|c|}{ DKB 390} & \multirow{2}{*}{$\frac{\text { Efic. }}{0^{2}}$} & \multicolumn{2}{|c|}{ P30F53 } & \multirow{2}{*}{$\begin{array}{c}\text { Efic. } \\
0\end{array}$} & \multicolumn{2}{|c|}{ FÓRMULA } & \multirow{2}{*}{$\begin{array}{c}\text { Efic. } \\
0\end{array}$} & \multicolumn{2}{|c|}{ 2B587 } & \multirow{2}{*}{$\begin{array}{c}\text { Efic. } \\
0\end{array}$} & \multicolumn{2}{|c|}{ Média } \\
\hline & $0^{1}$ & $\mathrm{dA}^{*}$ & & 314,9 & $\mathrm{bA}$ & & 803,5 & $\mathrm{aA}$ & & 76,8 & $\mathrm{cA}$ & & 298,8 & A \\
\hline 2 & 0 & $\mathrm{dA}$ & 0 & 36,6 & $\mathrm{bD}$ & 88,3 & 133 & $\mathrm{aE}$ & 83,4 & 11,5 & $\mathrm{cC}$ & 85 & 45,3 & $\mathrm{E}$ \\
\hline 3 & 0 & $\mathrm{dA}$ & 0 & 115,2 & $\mathrm{bB}$ & 63,4 & 321,4 & $\mathrm{aB}$ & 60 & 24,5 & $\mathrm{cB}$ & 68,1 & 115,3 & B \\
\hline 4 & 0 & dA & 0 & 44,2 & $\mathrm{bD}$ & 85,9 & 162,3 & $\mathrm{aD}$ & 79,8 & 10,9 & $\mathrm{cC}$ & 85,7 & 54,3 & D \\
\hline 5 & 0 & dA & 0 & 58,6 & $\mathrm{bC}$ & 81,4 & 244,1 & $\mathrm{aC}$ & 69,6 & 19,1 & $\mathrm{cB}$ & 75 & 80,5 & $\mathrm{C}$ \\
\hline 6 & 0 & $\mathrm{dA}$ & 0 & 8,9 & $\mathrm{bE}$ & 97,1 & 20,4 & $\mathrm{aF}$ & 97,4 & 2,4 & $\mathrm{cD}$ & 96,8 & 7,9 & $\mathrm{~F}$ \\
\hline Média & 0 & d & & 96,4 & $\mathrm{~b}$ & & 280,8 & $\mathrm{a}$ & & 24,2 & c & & & \\
\hline $\mathrm{CV}(\%) \mathrm{H}$ & os & & & & & & & $\mathrm{CV}($ & $\%) \mathrm{Fu}$ & gicidas & 5,2 & & & \\
\hline
\end{tabular}

1AACPD; ${ }^{2}$ Eficácia de controle (\%) (Abbott, 1925); *Médias seguidas pela mesma letra, maiúscula na coluna e minúscula na linha, não diferem entre si pelo teste de Tukey $(\mathrm{p} \leq 0,05)$. Dados originais. Para efeito de análise os dados de AACPD foram transformados em $\sqrt{x+5}$; **Fungicidas: 1- Testemunha, 2- Fluxapiroxade + Piraclostrobina + Adjuvante (50,1 + 99,9 g i.a. ha-1 + 0,5\% v/v), 3- Benzovindiflupir + Azoxistrobina + Adjuvante $(49,5+99$ g i.a. ha-1 $+0,5 \%$ v/v), 4- Bixafen + Trifloxistrobina + Protioconazol + Adjuvante $(50+60+70$ g i.a. $\left.\mathrm{ha}^{-1}+0,5 \% \mathrm{v} / \mathrm{v}\right), 5$ - Trifloxistrobina + Protioconazol + Adjuvante $\left(75+87,5 \mathrm{~g}\right.$ i.a. ha $\left.\mathrm{h}^{-1}+0,5 \% \mathrm{v} / \mathrm{v}\right), 6$ - Controle Total.

Para mancha-branca todos os híbridos diferiram entre si quanto a AACPMb, tendo o híbrido Fórmula a maior média para a variável enquanto que 2B587 a menor (tabela 19). Para DKB390 e P30F53 têm-se médias intermediárias a esses. No experimento 2 a mancha-branca 
ocorreu de forma similar ao primeiro, tanto em termos da época de manifestação dos primeiros sintomas, quanto da magnitude da severidade da doença.

Na média dos tratamentos, todos os fungicidas diferiram entre si no controle da manchabranca. Na média dos fungicidas, Bixafen+Trifloxistrobina+Protioconazol apresentou o melhor controle da doença, com AACPMb superior apenas ao Controle Total. Vale ressaltar que os fungicidas contendo carboxamidas Bixafen+Trifloxistrobina+Protioconazol e Fluxapiroxade+Piraclostrobina obtiveram eficácias de controle superiores à mistura triazól + estrobilurina Trifloxistrobina+Protioconazol em todos os híbridos estudados. O fungicida com carboxamida Benzovindiflupir+Azoxistrobina obteve controle insatisfatório de mancha-branca quando se observa os valores de eficácia de controle da $\mathrm{AACPMb}$, valores estes inferiores a mistura triazól + estrobilurina Trifloxistrobina+Protioconazol. Quando analisado os valores de AACPMb, estes não diferiram estatisticamente em alguns híbridos de milho.

Tabela 19. Área abaixo da curva de progresso da mancha-branca (Phaeosphaeria maydis/Pantoea ananatis) (AACPMb) e eficácia de controle (\%) na cultura do milho (Zea mays) em função da aplicação de diferentes tratamentos fungicidas e híbridos de milho. Planaltina/DF, 2014.

\begin{tabular}{|c|c|c|c|c|c|c|c|c|c|c|c|c|c|c|}
\hline \multirow{2}{*}{$\frac{\text { Fung. ** }}{1}$} & \multicolumn{2}{|c|}{ DKB 390} & \multirow{2}{*}{$\begin{array}{c}\text { Efic. } \\
0^{2}\end{array}$} & \multicolumn{2}{|c|}{ P30F53 } & \multirow{2}{*}{$\begin{array}{c}\text { Efic. } \\
0\end{array}$} & \multicolumn{2}{|c|}{ FÓRMULA } & \multirow{2}{*}{$\begin{array}{c}\text { Efic. } \\
0\end{array}$} & \multicolumn{2}{|c|}{ 2B587 } & \multirow{2}{*}{$\begin{array}{c}\text { Efic. } \\
0\end{array}$} & \multicolumn{2}{|c|}{ Média } \\
\hline & $52,1^{1}$ & $\mathrm{cA}^{*}$ & & 186,9 & bA & & 221,0 & $\mathrm{aA}$ & & 42 & $\mathrm{dA}$ & & 125,5 & A \\
\hline 2 & 12 & $\mathrm{cD}$ & 77 & 41,7 & $\mathrm{bD}$ & 77,6 & 75,3 & $\mathrm{aD}$ & 65,9 & 8,4 & $\mathrm{cC}$ & 80 & 34,4 & D \\
\hline 3 & 37,5 & $\mathrm{cB}$ & 28 & 138,5 & bB & 25,9 & 187,5 & $\mathrm{aB}$ & 15,1 & 25,2 & $\mathrm{~dB}$ & 39,8 & 97,2 & B \\
\hline 4 & 8 & $\mathrm{cD}$ & 84,6 & 28,1 & $\mathrm{bE}$ & 84,9 & 50,9 & $\mathrm{aE}$ & 76,9 & 4,7 & $\mathrm{dD}$ & 88,6 & 22,9 & $\mathrm{E}$ \\
\hline 5 & 22,7 & $\mathrm{cC}$ & 56,3 & 96,6 & $\mathrm{bC}$ & 48,2 & 131,1 & $\mathrm{aC}$ & 40,6 & 20,7 & cB & 50,6 & 67,8 & C \\
\hline 6 & 2,2 & $\mathrm{bE}$ & 95,7 & 13,8 & $\mathrm{aF}$ & 92,6 & 17,5 & $\mathrm{aF}$ & 92 & 0,2 & $\mathrm{cE}$ & 99,4 & 8,4 & $\mathrm{~F}$ \\
\hline Média & 22,4 & $\mathrm{c}$ & & 84,3 & $\mathrm{~b}$ & & 113,9 & $\mathrm{a}$ & & 16,9 & d & & & \\
\hline $\mathrm{CV}(\%) \mathrm{H}$ & dos & & & & & & & & $\%$ ) Fur & sicidas & 4,6 & & & \\
\hline
\end{tabular}

1AACPD; ${ }^{2}$ Eficácia de controle (\%) (Abbott, 1925); *Médias seguidas pela mesma letra, maiúscula na coluna e minúscula na linha, não diferem entre si pelo teste de Tukey $(\mathrm{p} \leq 0,05)$. Dados originais. Para efeito de análise os dados de AACPD foram transformados em $\sqrt{x+5}$; **Fungicidas: 1- Testemunha, 2- Fluxapiroxade + Piraclostrobina + Adjuvante (50,1 + 99,9 g i.a. ha-1 + 0,5\% v/v), 3- Benzovindiflupir + Azoxistrobina + Adjuvante $(49,5+99$ g i.a. ha-1 $+0,5 \%$ v/v $), 4-$ Bixafen + Trifloxistrobina + Protioconazol + Adjuvante $(50+60+70 \mathrm{~g}$ i.a. $\left.\mathrm{ha}^{-1}+0,5 \% \mathrm{v} / \mathrm{v}\right), 5$ - Trifloxistrobina + Protioconazol + Adjuvante $\left(75+87,5 \mathrm{~g}\right.$ i.a. $\left.\mathrm{ha}^{-1}+0,5 \% \mathrm{v} / \mathrm{v}\right), 6$ - Controle Total.

Quanto ao patógeno Exserohilum turcicum verificou-se que a doença mancha-deturcicum foi menos severa do que na primeira época de semeadura do ensaio. Ao analisarmos a AACPMt o híbrido DKB390 apresentou a maior média entre os híbridos nos quais a doença foi avaliada (tabela 20). Já os genótipos P30F53 e 2B587 apresentaram comportamento similar 
em relação a evolução da doença, com médias de AACPMt não diferindo estatisticamente entre si. O híbrido P30F53 foi aquele em que obteve-se maior resposta ao uso de fungicidas. Assim como aconteceu no experimento 1, este híbrido contrariou a informação a respeito do mesmo no qual este teria moderada resistência a doença.

Em relação ao comportamento geral dos fungicidas nos diferentes híbridos observa-se que todos diferiram entre si pelas médias apresentadas e em relação à Testemunha. No geral, observando-se a médias, Bixafen+Trifloxistrobina+Protioconazol mostrou-se como o melhor fungicida no controle da mancha-de-turcicum. Bixafen+Trifloxistrobina+Protioconazol e Fluxapiroxade+Piraclostrobina, assim como no controle de mancha-branca, obtiveram eficácias de controle superiores à mistura triazól + estrobilurina Trifloxistrobina+Protioconazol em todos os híbridos estudados para mancha-de-turcicum.

Assim como ocorreu na primeira época, devido ao fato da doença iniciar cedo na cultura e antes às aplicações dos tratamentos fungicidas, pode ter prejudicado a eficiência dos fungicidas. É importante ressaltar que todos os fungicidas estudados têm suas performances maximizadas quando aplicados de forma preventiva no controle de doenças.

Tabela 20. Área abaixo da curva de progresso da mancha-de-turcicum (Exserohilum turcicum) (AACPMt) e eficácia de controle (\%) na cultura do milho (Zea mays) em função da aplicação de diferentes tratamentos fungicidas e híbridos de milho. Planaltina/DF, 2014.

\begin{tabular}{|c|c|c|c|c|c|c|c|c|c|c|c|c|c|c|}
\hline \multirow{2}{*}{$\frac{\text { Fung.** }}{1}$} & \multicolumn{2}{|c|}{ DKB 390} & \multirow{2}{*}{$\frac{\text { Efic. }}{0^{2}}$} & \multicolumn{2}{|c|}{ P30F53 } & \multirow{2}{*}{$\begin{array}{c}\text { Efic. } \\
0\end{array}$} & \multicolumn{2}{|c|}{ FÓRMULA } & \multirow{2}{*}{$\begin{array}{c}\text { Efic. } \\
0\end{array}$} & \multicolumn{2}{|c|}{ 2B587 } & \multirow{2}{*}{$\begin{array}{c}\text { Efic. } \\
0\end{array}$} & \multicolumn{2}{|c|}{ Média } \\
\hline & $233,4^{1}$ & $a A^{*}$ & & 152,6 & bA & & 0 & $\mathrm{cA}$ & & 141,9 & bA & & 132 & A \\
\hline 2 & 109,2 & $\mathrm{aC}$ & 53,1 & 53,6 & $\mathrm{bC}$ & 64,8 & 0 & $\mathrm{cA}$ & 0 & 56,9 & bCD & 59,9 & 55 & D \\
\hline 3 & 153,9 & $\mathrm{aB}$ & 34 & 64,9 & bB & 57,4 & 0 & $\mathrm{cA}$ & 0 & 69,4 & bB & 51 & 72,0 & B \\
\hline 4 & 96,5 & $\mathrm{aD}$ & 58,6 & 46,6 & $\mathrm{cC}$ & 69,4 & 0 & $\mathrm{dA}$ & 0 & 55,3 & bD & 61 & 49,6 & E \\
\hline 5 & 121,1 & $\mathrm{aC}$ & 48,1 & 63,8 & bB & 58,2 & 0 & $\mathrm{cA}$ & 0 & 66,4 & $\mathrm{bBC}$ & 53,1 & 62,8 & $\mathrm{C}$ \\
\hline 6 & 78,7 & $\mathrm{aE}$ & 66,3 & 27,9 & $\mathrm{cD}$ & 81,7 & 0 & $\mathrm{dA}$ & 0 & 46 & $\mathrm{bE}$ & 67,5 & 38,2 & $\mathrm{~F}$ \\
\hline Média & 132,1 & $\mathrm{a}$ & & 68,2 & $\mathrm{~b}$ & & 0 & $\mathrm{c}$ & & 72,7 & $\mathrm{~b}$ & & & \\
\hline $\mathrm{CV}(\%)$ & idos 4 & & & & & & & (1/) & Fungic & & 4,1 & & & \\
\hline
\end{tabular}

1AACPD; ${ }^{2}$ Eficácia de controle (\%) (Abbott, 1925); *Médias seguidas pela mesma letra, maiúscula na coluna e minúscula na linha, não diferem entre si pelo teste de Tukey $(\mathrm{p} \leq 0,05)$. Dados originais. Para efeito de análise os dados de AACPD foram transformados em $\sqrt{x+5}$; **Fungicidas: 1- Testemunha, 2- Fluxapiroxade + Piraclostrobina + Adjuvante (50,1 + 99,9 g i.a. ha-1 + 0,5\% v/v), 3- Benzovindiflupir + Azoxistrobina + Adjuvante $(49,5+99$ g i.a. ha-1 $+0,5 \%$ v/v), 4- Bixafen + Trifloxistrobina + Protioconazol + Adjuvante $(50+60+70$ g i.a. $\left.\mathrm{ha}^{-1}+0,5 \% \mathrm{v} / \mathrm{v}\right), 5$ - Trifloxistrobina + Protioconazol + Adjuvante $\left(75+87,5 \mathrm{~g}\right.$ i.a. ha $\left.{ }^{-1}+0,5 \% \mathrm{v} / \mathrm{v}\right), 6$ - Controle Total.

Diferentemente do que ocorreu na primeira época, a ferrugem-comum (Puccinia sorghi) manifestou-se apenas no híbrido P30F53 e de forma mais branda (tabela 21). Nos demais não foram visualizados sintomas da doença. Todos os tratamentos diferiram da Testemunha. $\mathrm{O}$ Controle Total proporcionou o maior controle da doença com a menor AACPFc. 
Entre os fungicidas, Benzovindiflupir+Azoxistrobina mostrou o melhor controle de ferrugem-comum, assim como já havia tido o melhor controle das ferrugens ocorridas no experimento 1 (tabelas 6 e 7), o que mostra sua maior especificidade às ferrugens do que a fungos necrotróficos. Os demais não diferiram entre si, com comportamento ligeiramente abaixo deste. Apenas o Controle Total obteve eficácia superior a $80 \%$.

A precocidade da ocorrência da ferrugem-comum e o fato de ter iniciado nas folhas inferiores das plantas de milho pode ter afetado a performance dos fungicidas de modo geral. Este fato vem ao encontro do exposto por Juliatti et al. (2004), no qual também obtiveram menores controles da ferrugem-comum pelas aplicações terem ocorridas em estádios fenológicos da cultura mais avançados em relação ao momento em que o patógeno estabeleceuse nas plantas de milho. Em trabalhos visando exclusivamente alvos como Puccinia sorghi, em que sua ocorrência for cedo e em folhas baixeiras das plantas de milho, seu controle com fungicidas deve ser antecipado para melhor avaliação de suas performances.

Tabela 21. Área abaixo da curva de progresso da ferrugem-comum (Puccinia sorghi) (AACPFc) e eficácia de controle (\%) na cultura do milho (Zea mays) em função da aplicação de diferentes tratamentos fungicidas e híbridos de milho. Planaltina/DF, 2014.

\begin{tabular}{|c|c|c|c|c|c|c|c|c|c|c|c|c|c|c|}
\hline \multirow{2}{*}{$\frac{\text { Fung.** }}{1}$} & \multicolumn{2}{|c|}{ DKB 390} & \multirow{2}{*}{$\begin{array}{c}\text { Efic. } \\
0^{2}\end{array}$} & \multicolumn{2}{|c|}{ P30F53 } & \multirow{2}{*}{$\begin{array}{c}\text { Efic. } \\
0\end{array}$} & \multicolumn{2}{|c|}{ FÓRMULA } & \multirow{2}{*}{$\begin{array}{c}\text { Efic. } \\
0\end{array}$} & \multicolumn{2}{|c|}{ 2B587 } & \multirow{2}{*}{$\begin{array}{c}\text { Efic. } \\
0\end{array}$} & \multicolumn{2}{|c|}{ Média } \\
\hline & $0^{1}$ & $\mathrm{bA}^{*}$ & & 43,9 & $\mathrm{aA}$ & & 0 & $\mathrm{bA}$ & & 0 & $\mathrm{bA}$ & & 11 & A \\
\hline 2 & 0 & bA & 0 & 17,4 & $\mathrm{aB}$ & 60,3 & 0 & $\mathrm{bA}$ & 0 & 0 & $\mathrm{bA}$ & 0 & 4,4 & B \\
\hline 3 & 0 & $\mathrm{bA}$ & 0 & 11,5 & $\mathrm{aC}$ & 73,6 & 0 & $\mathrm{bA}$ & 0 & 0 & $\mathrm{bA}$ & 0 & 2,9 & $\mathrm{C}$ \\
\hline 4 & 0 & $\mathrm{bA}$ & 0 & 18,1 & $\mathrm{aB}$ & 58,7 & 0 & $\mathrm{bA}$ & 0 & 0 & bA & 0 & 4,5 & B \\
\hline 5 & 0 & $\mathrm{bA}$ & 0 & 18,1 & $\mathrm{aB}$ & 58,7 & 0 & bA & 0 & 0 & bA & 0 & 4,5 & B \\
\hline 6 & 0 & $\mathrm{bA}$ & 0 & 7,7 & $\mathrm{aD}$ & 82,4 & 0 & bA & 0 & 0 & $\mathrm{bA}$ & 0 & 1,9 & D \\
\hline Média & 0 & $\mathrm{~b}$ & & 19,5 & $\mathrm{a}$ & & 0 & $\mathrm{~b}$ & & 0 & $\mathrm{~b}$ & & & \\
\hline
\end{tabular}

1AACPD; ${ }^{2}$ Eficácia de controle (\%) (Abbott, 1925); *Médias seguidas pela mesma letra, maiúscula na coluna e minúscula na linha, não diferem entre si pelo teste de Tukey $(\mathrm{p} \leq 0,05)$. Dados originais. Para efeito de análise os dados de AACPD foram transformados em $\sqrt{x+5}$; **Fungicidas: 1- Testemunha, 2- Fluxapiroxade + Piraclostrobina + Adjuvante (50,1 + 99,9 g i.a. ha $\left.{ }^{-1}+0,5 \% \mathrm{v} / \mathrm{v}\right), 3-$ Benzovindiflupir + Azoxistrobina + Adjuvante $\left(49,5+99\right.$ g i.a. ha ${ }^{-1}+0,5 \%$ v/v $), 4-$ Bixafen + Trifloxistrobina + Protioconazol + Adjuvante $(50+60+70$ g i.a. $\left.\mathrm{ha}^{-1}+0,5 \% \mathrm{v} / \mathrm{v}\right), 5$ - Trifloxistrobina + Protioconazol + Adjuvante $\left(75+87,5 \mathrm{~g}\right.$ i.a. $\left.\mathrm{ha}^{-1}+0,5 \% \mathrm{v} / \mathrm{v}\right), 6$ - Controle Total.

Enquanto que o patógeno Puccinia sorghi pode não ter encontrado as condições mais ideais para sua manifestação no experimento 2, o patógeno causador da ferrugem-polissora, Puccinia polysora encontrou neste período condições ambientes mais ideais quando 
comparados ao experimento 1. Fato este comprovado pela sua ocorrência em três dos quatro híbridos estudados (tabela 22).

Diferentemente do experimento 1 em que somente no híbrido P30F53 a ferrugempolissora foi avaliada, no segundo, somente no híbrido Fórmula a mesma não ocorreu. Entre os híbridos avaliados, P30F53 apresentou a maior média de AACPFp, diferindo dos demais, enquanto que DKB390 e 2B587 tiveram médias menores e similares entre si. O híbrido DKB390 foi o mais responsivo ao controle químico quando observados os valores de eficácias obtidos pelos tratamentos fungicidas. Ao analisarmos a médias dos tratamentos fungicidas verifica-se que todos diferiram da Testemunha sem aplicação. Sem considerarmos o Controle Total, Benzovindiflupir+Azoxistrobina foi o tratamento fungicida que mais se destacou entre os híbridos, com valor médio de AACPFp superior apenas ao Controle Total. No DKB390 e 2B587 todos os tratamentos fungicidas apresentaram eficácias superiores a 80\% de controle da ferrugem-polissora.

Vale destacar que Benzovindiflupir+Azoxistrobina apresentou comportamento semelhante ao Controle Total nos híbridos DKB390 e 2B587, e no P30F53 só obteve comportamento inferior a este. No híbrido DKB390 Bixafen+Trifloxistrobina+Protioconazol não diferiu de Benzovindiflupir+Azoxistrobina no controle da ferrugem-polissora.

A doença foi identificada nos híbridos a partir do pendoamento das plantas de milho, quando todos os tratamentos fungicidas já haviam sido aplicados, o que também favoreceu o controle efetivo da ferrugem-polissora. Em geral todos os fungicidas contendo carboxamidas apresentaram bom controle da doença. O fungicida Bixafen+Trifloxistrobina+Protioconazol não diferiu da mistura triazól + estrobilurina Trifloxistrobina+Protioconazol nos híbridos DKB390 e P30F53, enquanto que Fluxapiroxade+Piraclostrobina não diferiu deste apenas no DKB390.

É importante ressaltar comportamento superior do fungicida Benzovindiflupir+Azoxistrobina para ambas as ferrugens avaliadas nas duas épocas de semeadura do presente trabalho, mostrando-se melhor no controle de patógenos biotróficos do que necrotróficos, como as manchas foliares. 
Tabela 22. Área abaixo da curva de progresso da ferrugem-polissora (Puccinia polysora) (AACPFc) e eficácia de controle (\%) na cultura do milho (Zea mays) em função da aplicação de diferentes tratamentos fungicidas e híbridos de milho. Planaltina/DF, 2014.

\begin{tabular}{|c|c|c|c|c|c|c|c|c|c|c|c|c|c|c|}
\hline \multirow{2}{*}{$\frac{\text { Fung.** }}{1}$} & \multicolumn{2}{|c|}{ DKB 390} & \multirow{2}{*}{$\frac{\text { Efic. }}{0^{2}}$} & \multicolumn{2}{|c|}{ P30F53 } & \multirow{2}{*}{$\frac{\text { Efic. }}{0}$} & \multicolumn{2}{|c|}{ FÓRMULA } & \multirow{2}{*}{$\begin{array}{c}\text { Efic. } \\
0\end{array}$} & \multicolumn{2}{|c|}{ 2B587 } & \multirow{2}{*}{$\frac{\text { Efic. }}{0}$} & \multicolumn{2}{|c|}{ Média } \\
\hline & $29,1^{1}$ & $\mathrm{bA}^{*}$ & & 86,5 & $\mathrm{aA}$ & & 0 & $\mathrm{cA}$ & & 27,5 & $\mathrm{bA}$ & & 35,8 & A \\
\hline 2 & 2,1 & $\mathrm{bB}$ & 92,6 & 16,1 & $\mathrm{aC}$ & 81,3 & 0 & $\mathrm{cA}$ & 0 & 2,7 & $\mathrm{bC}$ & 90 & 5,2 & $\mathrm{C}$ \\
\hline 3 & 0,4 & $\mathrm{bCD}$ & 98,7 & 7,25 & $\mathrm{aD}$ & 91,6 & 0 & bA & 0 & 0,2 & $b E$ & 99,1 & 2 & $\mathrm{D}$ \\
\hline 4 & 1,4 & $\mathrm{bBC}$ & 95 & 18,3 & $\mathrm{aBC}$ & 78,8 & 0 & $\mathrm{cA}$ & 0 & 1,5 & $\mathrm{bCD}$ & 94,5 & 5,3 & $\mathrm{C}$ \\
\hline 5 & 1,7 & $\mathrm{cB}$ & 94,2 & 20,4 & $\mathrm{aB}$ & 76,4 & 0 & $\mathrm{dA}$ & 0 & 5,4 & $\mathrm{bB}$ & 80,4 & 6,9 & B \\
\hline 6 & 0 & $\mathrm{aD}$ & 100 & 0,5 & $\mathrm{aE}$ & 99,4 & 0 & $\mathrm{aA}$ & 0 & 0,5 & $\mathrm{aDE}$ & 98,1 & 0,2 & $\mathrm{E}$ \\
\hline Média & 5,8 & $\mathrm{~b}$ & & 24,8 & $\mathrm{a}$ & & 0 & $\mathrm{c}$ & & 6,3 & $\mathrm{~b}$ & & & \\
\hline $\mathrm{CV}(\%) \mathrm{H}$ & los & & & & & & & (\%) & Ingi & & 9,9 & & & \\
\hline
\end{tabular}

1AACPD; ${ }^{2}$ Eficácia de controle (\%) (Abbott, 1925); *Médias seguidas pela mesma letra, maiúscula na coluna e minúscula na linha, não diferem entre si pelo teste de Tukey $(\mathrm{p} \leq 0,05)$. Dados originais. Para efeito de análise os dados de AACPD foram transformados em $\sqrt{x+5}$; **Fungicidas: 1- Testemunha, 2- Fluxapiroxade + Piraclostrobina + Adjuvante (50,1 + 99,9 g i.a. ha-1 + 0,5\% v/v), 3- Benzovindiflupir + Azoxistrobina + Adjuvante $\left(49,5+99\right.$ g i.a. ha $a^{-1}+0,5 \%$ v/v $), 4-$ Bixafen + Trifloxistrobina + Protioconazol + Adjuvante $(50+60+70$ g i.a. $\left.\mathrm{ha}^{-1}+0,5 \% \mathrm{v} / \mathrm{v}\right), 5$ - Trifloxistrobina + Protioconazol + Adjuvante $\left(75+87,5 \mathrm{~g}\right.$ i.a. $\left.\mathrm{ha}^{-1}+0,5 \% \mathrm{v} / \mathrm{v}\right), 6$ - Controle Total.

A mancha-de-cabatiela (Kabatiella zeae) manifestou-se de forma mais agressiva no híbrido DKB390 na segunda época de semeadura (tabela 23). Já para 2B587 o mesmo não ocorreu. Houve diferença significativa entre as médias da AACPMc dos híbridos DKB390 E $2 \mathrm{~B} 587$.

O Controle Total apresentou a menor AACPMc. Todos os tratamentos fungicidas diferiram da Testemunha com menores valores da área abaixo da curva de progresso da mancha-de-cabatiela. Os fungicidas Bixafen+Trifloxistrobina+Protioconazol e Fluxapiroxade+Piraclostrobina apresentaram os menores valores da AACPMc, sendo que este último não diferenciou-se de Trifloxistrobina+Protioconazol. O fungicida Benzovindiflupir+Azoxistrobina apresentou o menor controle da mancha-de-cabatiela entre os fungicidas. Com exceção a Benzovindiflupir+Azoxistrobina, todos os fungicidas apresentaram eficácias superiores a $80 \%$ de controle da doença em ambos os híbridos em que a doença se manifestou. No híbrido DKB390 todos os tratamentos fungicidas diferiram estatisticamente entre si. Já no 2B587, com exceção a Testemunha, com a maior AACPMc, e o Controle Total, com a menor, os demais fungicidas não diferiram entre si. 
Tabela 23. Área abaixo da curva de progresso da mancha-de-cabatiela (Kabatiella zeae) (AACPMc) e eficácia de controle (\%) na cultura do milho (Zea mays) em função da aplicação de diferentes tratamentos fungicidas e híbridos de milho. Planaltina/DF, 2014.

\begin{tabular}{|c|c|c|c|c|c|c|c|c|c|c|c|c|c|c|}
\hline \multirow{2}{*}{$\frac{\text { Fung.** }}{1}$} & \multicolumn{2}{|c|}{ DKB 390} & \multirow{2}{*}{$\begin{array}{c}\text { Efic. } \\
0^{2}\end{array}$} & \multicolumn{2}{|c|}{ P30F53 } & \multirow{2}{*}{$\begin{array}{c}\text { Efic. } \\
0\end{array}$} & \multicolumn{2}{|c|}{ FÓRMULA } & \multirow{2}{*}{$\begin{array}{c}\text { Efic. } \\
0\end{array}$} & \multicolumn{2}{|c|}{ 2B587 } & \multirow{2}{*}{$\begin{array}{c}\text { Efic. } \\
0\end{array}$} & \multicolumn{2}{|c|}{ Média } \\
\hline & $221,0^{1}$ & $\mathrm{aA} *$ & & 0 & $\mathrm{cA}$ & & 0 & $\mathrm{cA}$ & & 34,5 & bA & & 63,9 & A \\
\hline 2 & 28,3 & $\mathrm{aD}$ & 87,1 & 0 & $\mathrm{cA}$ & 0 & 0 & $\mathrm{cA}$ & 0 & 6,5 & $\mathrm{bB}$ & 81,1 & 8,7 & $\mathrm{CD}$ \\
\hline 3 & 59,9 & $\mathrm{aB}$ & 72,9 & 0 & $\mathrm{cA}$ & 0 & 0 & $\mathrm{cA}$ & 0 & 7 & bB & 79,7 & 16,7 & B \\
\hline 4 & 20,4 & $\mathrm{aE}$ & 90,7 & 0 & $\mathrm{cA}$ & 0 & 0 & $\mathrm{cA}$ & 0 & 6,5 & bB & 81,1 & 6,7 & $\mathrm{D}$ \\
\hline 5 & 41,7 & $\mathrm{aC}$ & 81 & 0 & $\mathrm{cA}$ & 0 & 0 & $\mathrm{cA}$ & 0 & 6,5 & $\mathrm{bB}$ & 81,1 & 12,0 & C \\
\hline 6 & 6,6 & $\mathrm{aF}$ & 97 & 0 & bA & 0 & 0 & bA & 0 & 1,1 & $\mathrm{bC}$ & 96,7 & 1,94 & E \\
\hline Média & 63,0 & $\mathrm{a}$ & & 0 & $\mathrm{c}$ & & 0 & $\mathrm{c}$ & & 10,3 & $\mathrm{~b}$ & & & \\
\hline
\end{tabular}

1AACPD; ${ }^{1}$ Eficácia de controle (\%) (Abbott, 1925); *Médias seguidas pela mesma letra, maiúscula na coluna e minúscula na linha, não diferem entre si pelo teste de Tukey $(\mathrm{p} \leq 0,05)$. Dados originais. Para efeito de análise os dados de AACPD foram transformados em $\sqrt{x+5}$; **Fungicidas: 1- Testemunha, 2- Fluxapiroxade + Piraclostrobina + Adjuvante (50,1 + 99,9 g i.a. ha-1 + 0,5\% v/v), 3- Benzovindiflupir + Azoxistrobina + Adjuvante $\left(49,5+99\right.$ g i.a. ha $a^{-1}+0,5 \%$ v/v $), 4-$ Bixafen + Trifloxistrobina + Protioconazol + Adjuvante $(50+60+70$ g i.a. $\left.\mathrm{ha}^{-1}+0,5 \% \mathrm{v} / \mathrm{v}\right), 5$ - Trifloxistrobina + Protioconazol + Adjuvante $\left(75+87,5 \mathrm{~g}\right.$ i.a. ha $\left.\mathrm{h}^{-1}+0,5 \% \mathrm{v} / \mathrm{v}\right)$, 6- Controle Total.

\subsubsection{Grãos ardidos}

O período de enchimento de grãos e maturação fisiológica da cultura milho na segunda época de semeadura teve condições ambientes que não favoreceram a ocorrência de grãos ardidos como ocorreu na primeira época (figura 1).

A interação foi significativa entre os fatores híbridos e fungicidas para esta variável (Apêndices 1 e 3). Quando comparados os híbridos tem-se médias similares entre todos os quatros genótipos estudados, portanto, não diferindo estatisticamente um do outro (tabela 24).

Para os tratamentos fungicidas, todos diferiram significativamente da Testemunha. Os resultados, apesar das menores incidências de grãos ardidos quando comparados ao experimento 1, vão ao encontro destes, e ainda, corroboram com os resultados encontrados por vários autores sobre a redução de grãos ardidos com o uso de fungicidas (JULIATTI et al. 2007; DUARTE et al. 2009; BRITO, 2010).

Os melhores controles de grãos ardidos, pelas médias entre os híbridos, são os tratamentos Controle Total, Bixafen+Trifloxistrobina+Protioconazol e Trifloxistrobina+Protioconazol, com comportamentos similares, não diferindo entre si. Os fungicidas Fluxapiroxade+Piraclostrobina e Benzovindiflupir+Azoxistrobina, apesar do controle um pouco inferior, não diferiram de Trifloxistrobina+Protioconazol. 
O híbrido 2B587 teve seu tratamento Testemunha com a menor incidência de grãos ardidos e não diferenciou-se em relação aos demais tratamentos fungicidas, com exceção ao Controle Total que diferiu de todos estes. No híbrido DKB390 todos os fungicidas obtiveram controle de grãos ardidos semelhante ao Controle Total. Neste híbrido a incidência de grãos ardidos variou de $0,2 \%$ a 1,38\% nos tratamentos Controle Total e Testemunha, respectivamente. Ao analisarmos P30F53 e Fórmula, há pouca diferença entre esses valores, com a mesma tendência para o melhor e pior tratamento com grãos ardidos. De forma geral, com exceção ao híbrido 2B587, nos demais híbridos todos os tratamentos fungicidas reduziram significativamente a incidência de grãos ardidos.

Os resultados demonstram a importância da proteção das plantas de milho uma vez que muitos patógenos causadores de grãos ardidos são os mesmos causadores de podridões de colmo e espiga de milho. Uma vez os patógenos causadores de grãos ardidos sendo controlados antes do período crítico de infecção, período reprodutivo em diante, o sucesso da redução da incidência de grãos ardidos é maior.

Tabela 24. Incidência de grãos ardidos (\%) e eficácia de controle (\%) na cultura do milho (Zea mays) em função da aplicação de diferentes tratamentos fungicidas e híbridos de milho. Planaltina/DF, 2014.

\begin{tabular}{|c|c|c|c|c|c|c|c|c|c|c|c|c|c|c|}
\hline \multirow{2}{*}{$\frac{\text { Fung.** }}{1}$} & \multicolumn{2}{|c|}{ DKB 390} & \multirow{2}{*}{$\frac{\text { Efic. }}{0^{2}}$} & \multicolumn{2}{|c|}{ P30F53 } & \multirow{2}{*}{$\begin{array}{c}\text { Efic. } \\
0\end{array}$} & \multicolumn{2}{|c|}{ FÓRMULA } & \multirow{2}{*}{$\begin{array}{c}\text { Efic. } \\
0\end{array}$} & \multicolumn{2}{|c|}{ 2B587 } & \multirow{2}{*}{$\frac{\text { Efic. }}{0}$} & \multicolumn{2}{|c|}{ Média } \\
\hline & $1,4^{1}$ & $a b A^{*}$ & & 1,4 & $\mathrm{aA}$ & & 1,5 & $\mathrm{aA}$ & & 0,8 & bA & & 1,3 & A \\
\hline 2 & 0,4 & $\mathrm{aB}$ & 69,1 & 0,6 & $\mathrm{aBC}$ & 60,3 & 0,3 & $\mathrm{aBC}$ & 77 & 0,7 & $\mathrm{aAB}$ & 17,7 & 0,5 & B \\
\hline 3 & 0,3 & $\mathrm{bB}$ & 76,3 & 0,7 & $\mathrm{aB}$ & 48,3 & 0,5 & $a b B$ & 67,2 & 0,5 & $\mathrm{abAB}$ & 35,3 & 0,5 & B \\
\hline 4 & 0,2 & $\mathrm{aB}$ & 85,4 & 0,2 & $\mathrm{aCD}$ & 84,5 & 0,3 & $\mathrm{aBC}$ & 77 & 0,4 & $\mathrm{aAB}$ & 47 & 0,3 & $\mathrm{C}$ \\
\hline 5 & 0,5 & $\mathrm{abB}$ & 65,4 & 0,4 & $\mathrm{abBCD}$ & 74,1 & 0,2 & $\mathrm{bBC}$ & 88,5 & 0,6 & $\mathrm{aAB}$ & 29,4 & 0,4 & $\mathrm{BC}$ \\
\hline 6 & 0,2 & $\mathrm{aB}$ & 85,4 & 0,2 & $\mathrm{aD}$ & 86,2 & 0,1 & $\mathrm{aC}$ & 90,1 & 0,4 & $\mathrm{aB}$ & 50 & 0,2 & $\mathrm{C}$ \\
\hline Média & 0,5 & $\mathrm{a}$ & & 0,6 & $\mathrm{a}$ & & 0,5 & $\mathrm{a}$ & & 0,6 & $\mathrm{a}$ & & & \\
\hline $\mathrm{CV}(\%) \mathrm{H}$ & oridos & 46,9 & & & & & & $V(\%) \mathrm{F}$ & ungicic & & 30,0 & & & \\
\hline
\end{tabular}

Incidência de grãos ardidos (\%); ${ }^{2}$ Eficácia de controle (\%) (Abbott, 1925); *Médias seguidas pela mesma letra, maiúscula na coluna e minúscula na linha, não diferem entre si pelo teste de Tukey $(\mathrm{p} \leq 0,05)$. Dados originais. Para efeito de análise os dados de incidência de grãos ardidos foram transformados em $\log (\mathrm{x}+1)$. **Fungicidas: 1Testemunha, 2- Fluxapiroxade + Piraclostrobina + Adjuvante $\left(50,1+99,9\right.$ g i.a. ha ${ }^{-1}+0,5 \%$ v/v), 3Benzovindiflupir + Azoxistrobina + Adjuvante $\left(49,5+99 \mathrm{~g}\right.$ i.a. $\left.\mathrm{ha}^{-1}+0,5 \% \mathrm{v} / \mathrm{v}\right), 4-$ Bixafen + Trifloxistrobina + Protioconazol + Adjuvante $\left(50+60+70 \mathrm{~g}\right.$ i.a. ha $\left.^{-1}+0,5 \% \mathrm{v} / \mathrm{v}\right), 5$ - Trifloxistrobina + Protioconazol + Adjuvante $\left(75+87,5\right.$ g i.a. ha ${ }^{-1}+0,5 \%$ v/v), 6- Controle Total.

\subsubsection{Patologia de grãos (Incidência de Fusarium verticillioides)}

Ao analisar a variância para a variável incidência de Fusarium verticillioides em grãos de milho, esta mostrou haver interação significativa entre os fatores híbridos e fungicidas 
(Apêndices 1 e 3). No experimento 2, enquanto dois híbridos tem a incidência de Fusarium sp. diminuídas, como no DKB390 e P30F53, nos híbridos Fórmula e 2B587 há um aumento na incidência do fungo nos grãos de milho, em relação ao que ocorreu no experimento 1 (tabelas 10 e 25). Os genótipos Fórmula e P30F53 obtiveram as maiores incidências de Fusarium sp., não diferindo entre si, e DKB390 a menor incidência do fungo nos grãos. O 2B587 obteve comportamento intermediário, diferindo estatisticamente dos demais.

Aos analisarmos as médias para os tratamentos fungicidas, todos diferiram significativamente do tratamento Testemunha sem aplicação. Com exceção ao fungicida Benzovindiflupir+Azoxistrobina, todos os demais não diferiram entre si quanto a incidência de Fusarium sp. Benzovindiflupir+Azoxistrobina apresentou o menor controle do patógeno, superior apenas ao tratamento Testemunha. No híbrido Fórmula observa-se este mesmo comportamento. Nos híbridos P30F53 e 2B587 todos os tratamentos fungicidas tiveram comportamento similares, não diferindo significativamente entre si quanto ao controle de Fusarium sp. nos grãos. No híbrido DKB390 apenas Fluxapiroxade+Piraclostrobina diferenciou-se do tratamento Testemunha. Também, observa-se neste genótipo a menor resposta ao uso de fungicidas para o controle de Fusarium sp. em grãos de milho. A maior incidência do fungo foi no tratamento Testemunha do híbrido Fórmula com $89 \%$ dos grãos infectados com o fungo. Já 2B587 teve em sua Testemunha 31,8\% de incidência.

Os resultados de incidência de Fusarium sp. em grãos de milho, em ambos os experimentos, mostram a dificuldade de controle do patógeno pelo uso de fungicidas em parte área das plantas de milho. 
Tabela 25. Incidência de Fusarium verticillioides (\%) em grãos de milho e eficácia de controle (\%) em função da aplicação de diferentes tratamentos fungicidas e híbridos de milho. Planaltina/DF, 2014.

\begin{tabular}{|c|c|c|c|c|c|c|c|c|c|c|c|c|c|c|}
\hline \multirow{2}{*}{$\begin{array}{c}\text { Fung.** } \\
1\end{array}$} & \multicolumn{2}{|c|}{ DKB 390} & \multirow{2}{*}{$\begin{array}{c}\text { Efic. } \\
0^{2}\end{array}$} & \multicolumn{2}{|c|}{ P30F53 } & \multirow{2}{*}{$\begin{array}{c}\text { Efic. } \\
0\end{array}$} & \multicolumn{2}{|c|}{ FÓRMULA } & \multirow{2}{*}{$\begin{array}{c}\text { Efic. } \\
0\end{array}$} & \multicolumn{2}{|c|}{ 2B587 } & \multirow{2}{*}{$\begin{array}{c}\text { Efic. } \\
0\end{array}$} & \multicolumn{2}{|c|}{ Média } \\
\hline & $31,8^{1}$ & dAB* & & 78 & bA & & 89 & $\mathrm{aA}$ & & 50 & $\mathrm{cA}$ & & 62,2 & A \\
\hline 2 & 19 & $\mathrm{cC}$ & 40,2 & 53,5 & $\mathrm{aB}$ & 31,4 & 57 & $\mathrm{aBC}$ & 35,9 & 40 & bAB & 20 & 42,4 & $\mathrm{C}$ \\
\hline 3 & 36,5 & $\mathrm{cA}$ & 14,9 & 53 & $a b B$ & 32 & 64 & $\mathrm{aB}$ & 28 & 42 & bcAB & 16 & 48,9 & B \\
\hline 4 & 26,5 & $\mathrm{cABC}$ & 16,5 & 51,5 & $\mathrm{aB}$ & 33,9 & 47,5 & $a b C$ & 46,6 & 35 & $\mathrm{bcB}$ & 30 & 40,1 & $\mathrm{C}$ \\
\hline 5 & 24 & $\mathrm{cBC}$ & 24,4 & 46,8 & $\mathrm{abB}$ & 40 & 58 & $\mathrm{aBC}$ & 34,8 & 34 & $\mathrm{bcB}$ & 32 & 40,7 & $\mathrm{C}$ \\
\hline 6 & 22,5 & $\mathrm{cBC}$ & 29,1 & 42 & $a b B$ & 46,1 & 48,3 & $\mathrm{aC}$ & 45,8 & 33,5 & $\mathrm{bcB}$ & 33 & 36,6 & $\mathrm{C}$ \\
\hline Média & 26,7 & $\mathrm{c}$ & & 54,1 & $\mathrm{a}$ & & 60,6 & $\mathrm{a}$ & & 39,1 & $\mathrm{~b}$ & & & \\
\hline $\mathrm{CV}(\%) \mathrm{I}$ & ridos & 12,4 & & & & & & $(\%) \mathrm{F}$ & ungici & & 9,0 & & & \\
\hline
\end{tabular}

1'Incidência de Fusarium verticillioides (\%); ${ }^{2}$ Eficácia de controle (Abbott, 1925); *Médias seguidas pela mesma letra, maiúscula na coluna e minúscula na linha, não diferem entre si pelo teste de Tukey $(\mathrm{p} \leq 0,05)$. Dados originais. Para efeito de análise os dados de incidência de Fusarium verticillioides foram transformados em $\operatorname{arcsen} \sqrt{x / 100}$. $*$ Fungicidas: 1- Testemunha, 2- Fluxapiroxade + Piraclostrobina + Adjuvante $(50,1+99,9 \mathrm{~g}$ i.a. ha $\left.{ }^{-1}+0,5 \% \mathrm{v} / \mathrm{v}\right), 3-$ Benzovindiflupir + Azoxistrobina + Adjuvante (49,5 + $99 \mathrm{~g}$ i.a. ha $\left.{ }^{-1}+0,5 \% \mathrm{v} / \mathrm{v}\right), 4-$ Bixafen + Trifloxistrobina + Protioconazol + Adjuvante $\left(50+60+70\right.$ g i.a. ha $\left.{ }^{-1}+0,5 \% \mathrm{v} / \mathrm{v}\right), 5-$ Trifloxistrobina + Protioconazol + Adjuvante $\left(75+87,5\right.$ g i.a. ha $\mathrm{ha}^{-1}+0,5 \%$ v/v $), 6$ - Controle Total.

\subsubsection{Produtividade de grãos}

As condições climáticas na segunda época de semeadura foram suficientes para manter elevados os níveis de produtividade de todos os híbridos (figura 1). Assim como ocorreu no experimento 1, a análise de variância mostrou não haver interação significativa entre os fatores híbridos (A) e fungicidas (B) (Apêndices 1 e 3).

Enquanto nos híbridos DKB390 e P30F53 observa-se uma pequena redução na produtividade em relação à primeira época, nos híbridos Fórmula e 2B587 tem-se uma pequena elevação nos valores (tabela 26). O genótipo 2B587 diferiu estatisticamente dos demais com a maior média de produtividade de grãos de milho. Já DKB390, P30F53 e Fórmula não diferiram entre si neste quesito. Todos os tratamentos fungicidas foram superiores e distintos significativamente do tratamento Testemunha, corroborando com os resultados obtidos por Lago e Nunes (2008), no qual obtivera com o híbrido P30F53 aumento significativo na produtividade com a utilização de fungicida estrobilurina + triazól.

Os fungicidas Bixafen+Trifloxistrobina+Protioconazol $\mathrm{e}$ Fluxapiroxade+Piraclostrobina não diferiram do Controle Total com as maiores médias de produtividade. No entanto, Trifloxistrobina+Protioconazol também não diferiu de Bixafen+Trifloxistrobina+Protioconazol e Fluxapiroxade+Piraclostrobina. Já 
Benzovindiflupir+Azoxistrobina, apesar da menor média de produtividade, não se distinguiu da mistura triazól + estrobilurina Trifloxistrobina+Protioconazol. Em termos de incremento de produtividade em relação ao tratamento Testemunha pelo uso de fungicidas, o híbrido 2B587 foi o menos responsivo, com incrementos de no máximo 9,6\% na produtividade. Observa-se neste híbrido que nenhum tratamento diferenciou-se da Testemunha sem aplicação. Já no Fórmula, híbrido com as maiores severidades de cercosporiose e mancha-branca, tem-se as maiores respostas em termos de produtividade pelo uso do controle químico de doenças. Neste, observou-se um incremento em relação à Testemunha de até 43,5\% com o Controle Total, o maior incremento entre todos os híbridos e fungicidas. Carneiro et al. (2003) relataram incrementos no rendimento de grãos de $8,2 \%$ a 31,3\% pela utilização de fungicidas triazóis e estrobilurinas. Jardine e Laca-Buendía (2009) também relata incrementos na produtividade de grãos de milho com o uso de fungicidas (estrobilurina + triazól) no controle de doenças foliares, apesar de não ter havido diferenças estatísticas entre os tratamentos avaliados em seu trabalho. No DKB 390, ao mesmo tempo em que todos os fungicidas assemelharam-se estatisticamente ao Controle Total, também não diferiram do tratamento Testemunha.

Tabela 26. Produtividade de grãos (kg.ha $\left.{ }^{1-}\right)$ da cultura do milho (Zea mays) e incremento de produtividade (\%) em função da aplicação de diferentes tratamentos fungicidas e híbridos de milho. Planaltina/DF, 2014.

\begin{tabular}{|c|c|c|c|c|c|c|c|c|c|c|c|c|c|c|}
\hline Fung.** & DKB & 390 & I.P. & P30 & & I.P. & FÓRM & JLA & I.P. & 2B5 & & I.P. & Méd & \\
\hline 1 & $8190^{1}$ & bB* & $0^{2}$ & 7959 & $\mathrm{bC}$ & 0 & 7358 & $\mathrm{bC}$ & 0 & 10204 & $\mathrm{aA}$ & 0 & 8427 & D \\
\hline 2 & 9433 & $\mathrm{bAB}$ & 15 & 9570 & $\mathrm{bAB}$ & 20 & 9420 & $\mathrm{bAB}$ & 28 & 10810 & $\mathrm{aA}$ & 6 & 9808 & $\mathrm{AB}$ \\
\hline 3 & 8407 & $\mathrm{bAB}$ & 3 & 9005 & $\mathrm{bBC}$ & 13 & 8555 & $\mathrm{bBC}$ & 16 & 10625 & $\mathrm{aA}$ & 4 & 9148 & $\mathrm{C}$ \\
\hline 4 & 9175 & bAB & 12 & 9904 & $\mathrm{ab} A B$ & 24 & 9669 & bAB & 31 & 10968 & $\mathrm{aA}$ & 7 & 9929 & $\mathrm{AB}$ \\
\hline 5 & 8445 & $\mathrm{bAB}$ & 3 & 9387 & $\mathrm{bAB}$ & 18 & 9531 & $\mathrm{bAB}$ & 30 & 10810 & $\mathrm{aA}$ & 6 & 9543 & BC \\
\hline 6 & 9654 & bA & 18 & 10353 & $\mathrm{abA}$ & 30 & 10555 & $\mathrm{abA}$ & 43 & 11187 & $\mathrm{aA}$ & 10 & 10437 & A \\
\hline Média & 8884 & b & & 9363 & $\mathrm{~b}$ & & 9181 & $\mathrm{~b}$ & & 10767 & a & & & \\
\hline
\end{tabular}

${ }^{1}$ Produtividade de grãos $\left(\mathrm{Kg}_{\text {g.ha }}{ }^{-1}\right) ;{ }^{2}$ Incremento de produtividade (I.P.) em relação ao tratamento Testemunha (\%); *Médias seguidas pela mesma letra, maiúscula na coluna e minúscula na linha, não diferem entre si pelo teste de Tukey $(\mathrm{p} \leq 0,05)$. **Fungicidas: 1- Testemunha, 2- Fluxapiroxade + Piraclostrobina + Adjuvante (50,1 + 99,9 g i.a. $\left.\mathrm{ha}^{-1}+0,5 \% \mathrm{v} / \mathrm{v}\right), 3-$ Benzovindiflupir + Azoxistrobina + Adjuvante $\left(49,5+99 \mathrm{~g}\right.$ i.a. ha ${ }^{-1}+0,5 \%$ v/v $), 4-$ Bixafen + Trifloxistrobina + Protioconazol + Adjuvante $\left(50+60+70\right.$ g i.a. ha ${ }^{-1}+0,5 \%$ v/v $), 5-$ Trifloxistrobina + Protioconazol + Adjuvante $\left(75+87,5\right.$ g i.a. ha ${ }^{-1}+0,5 \%$ v/v), 6- Controle Total. 


\subsubsection{Massa de mil grãos}

Diferentemente da produtividade, a massa de mil grãos (MMG) apresentou interação significativa entre os fatores híbridos e fungicidas, assim como ocorreu no experimento 1 (Apêndices 1 e 3). No experimento 2 tem se uma redução mais pronunciada na variável massa de mil grãos para os híbridos DKB390, P30F53 e 2B587 quando comparados os valores ocorridos no experimento 1 (tabelas 12 e 27). Para o híbrido Fórmula a variável massa de mil grãos manteve-se constante. O híbrido 2B587 diferenciou-se do demais e obteve a maior média para MMG, enquanto que Fórmula a menor. Os híbridos DKB390 e P30F53 obtiveram médias similares e intermediárias.

Todos os tratamentos fungicidas diferenciaram-se significativamente da Testemunha, com médias de MMG superiores a esta. Depois do Controle Total, com a maior média para MMMG, os fungicidas Fluxapiroxade+Piraclostrobina e Bixafen+Trifloxistrobina+Protioconazol diferenciaram-se dos demais tratamentos com as maiores médias para a variável massa de mil grãos. Seguido destes, Trifloxistrobina+Protioconazol diferenciou-se e apresentou maior média de MMG que o fungicida Benzovindiflupir+Azoxistrobina.

No híbrido fórmula percebe-se o maior incremento na massa de mil grãos pelo controle de doenças com os tratamentos fungicidas avaliados no ensaio, chegando a $24,4 \%$ com o Controle Total e 18,8\% com o fungicida Fluxapiroxade+Piraclostrobina. No híbrido 2B587 tem-se os menores incrementos na MMG, com no máximo 6\% com o Controle Total e 5\% com Fluxapiroxade+Piraclostrobina, maior entre os fungicidas. Nos híbridos DKB390 e 2B587 o fungicida Fluxapiroxade+Piraclostrobina apresentou comportamento similar ao Controle Total, não diferindo significativamente deste. Já Bixafen+Trifloxistrobina+Protioconazol não diferiu de Fluxapiroxade+Piraclostrobina nestes mesmos híbridos.

No genótipo 2B587 com as menores variações, apenas os tratamentos Controle Total e Fluxapiroxade+Piraclostrobina diferenciaram-se da Testemunha, sendo que os demais não diferiram desta. No híbrido Fórmula, Fluxapiroxade+Piraclostrobina, Bixafen+Trifloxistrobina+Protioconazol e Trifloxistrobina+Protioconazol não diferiram entre si e obtiveram médias inferiores apenas em relação ao Controle Total.

Entre os fungicidas contendo carboxamidas, Benzovindiflupir+Azoxistrobina foi aquele com menor efeito na variável massa de mil grãos. A mistura triazól + estrobilurina Trifloxistrobina+Protioconazol apresentou comportamento intermediário. De modo geral, 
todos os tratamentos fungicidas contribuíram para o melhor enchimento de grãos de milho pela proteção dos tecidos em parte aérea.

Tabela 27. Massa de mil grãos (g) (MMG) de milho e incremento na massa de mil grãos (\%) em função da aplicação de diferentes tratamentos fungicidas e híbridos de milho. Planaltina/DF, 2014.

\begin{tabular}{|c|c|c|c|c|c|c|c|c|c|c|c|c|c|c|}
\hline \multirow{2}{*}{$\frac{\text { Fung.** }}{1}$} & \multicolumn{2}{|c|}{ DKB 390} & \multirow{2}{*}{$\frac{\text { I.M. }}{0^{2}}$} & \multicolumn{2}{|c|}{ P30F53 } & \multirow{2}{*}{$\frac{\text { I.M. }}{0}$} & \multicolumn{2}{|c|}{ FÓRMULA } & \multirow{2}{*}{$\frac{\text { I.M. }}{0}$} & \multicolumn{2}{|c|}{ 2B587 } & \multirow{2}{*}{$\frac{\text { I.M. }}{0}$} & \multicolumn{2}{|c|}{ Média } \\
\hline & $301^{1}$ & $\mathrm{bD} *$ & & 291 & $\mathrm{cD}$ & & 265 & $\mathrm{dD}$ & & 334 & $\mathrm{aC}$ & & 298 & $\mathrm{E}$ \\
\hline 2 & 338 & $\mathrm{bAB}$ & 12 & 320 & $\mathrm{cBC}$ & 10 & 315 & $\mathrm{cB}$ & 19 & 350 & $\mathrm{aAB}$ & 5 & 331 & B \\
\hline 3 & 310 & $\mathrm{bCD}$ & 3 & 318 & $\mathrm{bC}$ & 9 & 285 & $\mathrm{cC}$ & 8 & 341 & $\mathrm{aBC}$ & 2 & 313 & D \\
\hline 4 & 327 & $\mathrm{bB}$ & 8 & 330 & $\mathrm{bB}$ & 14 & 311 & $\mathrm{cB}$ & 17 & 342 & $\mathrm{aBC}$ & 2 & 328 & B \\
\hline 5 & 313 & $\mathrm{cC}$ & 4 & 325 & bBC & 12 & 310 & $\mathrm{cB}$ & 17 & 341 & $\mathrm{aBC}$ & 2 & 322 & $\mathrm{C}$ \\
\hline 6 & 339 & $\mathrm{bA}$ & 12 & 347 & $\mathrm{abA}$ & 19 & 330 & $\mathrm{cA}$ & 24 & 354 & $\mathrm{aA}$ & 6 & 342 & A \\
\hline Média & 321 & $\mathrm{~b}$ & & 322 & $\mathrm{~b}$ & & 303 & $\mathrm{c}$ & & 343 & $\mathrm{a}$ & & & \\
\hline $\mathrm{CV}(\%)$ & bridos & 1,2 & & & & & & $(\%) \mathrm{I}$ & ungic & & 1,6 & & & \\
\hline
\end{tabular}

${ }^{1}$ Massa de mil grãos (g); ${ }^{2}$ Incremento na massa de mil grãos (I.M.) em relação ao tratamento Testemunha (\%); *Médias seguidas pela mesma letra, maiúscula na coluna e minúscula na linha, não diferem entre si pelo teste de Tukey ( $\mathrm{p} \leq 0,05)$.**Fungicidas: 1- Testemunha, 2- Fluxapiroxade + Piraclostrobina + Adjuvante (50,1 + 99,9 g i.a. $\left.\mathrm{ha}^{-1}+0,5 \% \mathrm{v} / \mathrm{v}\right), 3$ - Benzovindiflupir + Azoxistrobina + Adjuvante $\left(49,5+99 \mathrm{~g}\right.$ i.a. ha ${ }^{-1}+0,5 \%$ v/v), 4- Bixafen + Trifloxistrobina + Protioconazol + Adjuvante $\left(50+60+70\right.$ g i.a. ha $\left.{ }^{-1}+0,5 \% \mathrm{v} / \mathrm{v}\right), 5-$ Trifloxistrobina + Protioconazol + Adjuvante $\left(75+87,5\right.$ g i.a. ha ha $^{-1}+0,5 \%$ v/v), 6- Controle Total.

\subsection{6 Índice de vegetação por diferença normalizada (NDVI)}

A análise de variância para a variável NDVI na segunda época ou experimento 2 mostrou-se semelhante ao que ocorreu na primeira época, com exceção apenas na avaliação em VT no qual a diferença é significativa apenas entre fungicidas e não em ambos os fatores como ocorreu na primeira (tabelas 13 e 28). Logo, em V8 a diferença é significativa entre híbridos, em VT para fungicidas e R3 e R5 há interação entre os fatores híbridos (A) e fungicidas (B) (Apêndices 2 e 4).

Em V8 o DKB390 obteve a maior média de NDVI, mas não diferindo do híbrido 2B587. Este, por sua vez não difere do P30F53. O Fórmula obteve a menor média de NDVI mas não diferindo do P30F53. Entre os tratamentos fungicidas não há diferença significativa entre os mesmos.

No estádio VT não foi detectada diferença estatística entre os híbridos. Entre os tratamentos fungicidas, o Controle Total teve a maior média de NDVI, mas não distinta significativamente dos fungicidas Bixafen+Trifloxistrobina+Protioconazol e Fluxapiroxade+Piraclostrobina. A testemunha apresentou a menor média de NDVI, mas não 
diferiu estatisticamente dos fungicidas Benzovindiflupir+Azoxistrobina e Trifloxistrobina+Protioconazol. Apesar de já ter várias doenças manifestadas nos diferentes híbridos até este estádio da cultura, não é possível visualizar uma clara distinção entre os tratamentos fungicidas.

Em R3, os híbridos 2B587, DKB390 e P30F53 não diferiram estatisticamente quanto às médias de NDVI. Já o híbrido Fórmula, distinto destes, apresentou a menor média de NDVI no estádio fenológico R3 da cultura do milho. Entre os tratamentos fungicidas, todos diferiram significativamente da testemunha. O Controle Total obteve a maior média de NDVI, diferindo de todos os demais fungicidas. Os fungicidas Bixafen+Trifloxistrobina+Protioconazol, Fluxapiroxade+Piraclostrobina e Trifloxistrobina+Protioconazol não diferiram entre si. Já Benzovindiflupir+Azoxistrobina obteve a menor média de NDVI entre os fungicidas, mas não diferindo estatisticamente de Trifloxistrobina+Protioconazol. Ao compararmos os tratamentos Testemunhas do diferentes híbridos, a Testemunha do híbrido Fórmula diferiu dos demais com o menor NDVI. As testemunhas com maiores NDVI foram nos híbridos 2B587 e DKB390.

$\mathrm{Na}$ avaliação final de NDVI em R5 da cultura, tem se os híbridos divididos em dois grupos distintos, sendo que 2B587 e DKB390 apresentaram as maiores médias de NDVI, e P30F53 e Fórmula as menores. Todos os tratamentos fungicidas diferiram do tratamento Testemunha. O Controle Total apresentou a maior média de NDVI, enquanto que Bixafen+Trifloxistrobina+Protioconazol e Fluxapiroxade+Piraclostrobina as maiores médias entre os fungicidas. As menores médias foram dos fungicidas Trifloxistrobina+Protioconazol e Benzovindiflupir+Azoxistrobina, que não diferiram entre si. Ao comparar as Testemunhas de cada híbrido, o comportamento foi similar a avaliação anterior, com a Testemunha do Fórmula tendo o menor valor de NDVI, e os demais não diferindo entre si. O Controle Total com a menor severidade de doenças apresentou grande diferença de NDVI para os tratamentos Testemunhas, mostrando o potencial de uso desta ferramenta na avaliação de doenças na cultura do milho, dando ideia do real estado sanitário da cultura e do potencial produtivo.

Pode se observar que em ambas as épocas de semeadura, os fungicidas Bixafen+Trifloxistrobina+Protioconazol e Fluxapiroxade+Piraclostrobina, com carboxamidas, tiveram mantiveram os maiores valores de NDVI entre os tratamentos fungicidas, valores estes superiores ao fungicida triazól + estrobilurina Trifloxistrobina+Protioconazol. Outro ponto importante a ser observado é que assim como estes dois fungicidas, Bixafen+Trifloxistrobina+Protioconazol e Fluxapiroxade+Piraclostrobina, tiveram os melhores controles das doenças causadas por agentes necrotróficos no presente ensaio, tendo 
assim mais área sadia, o mesmo pôde ser detectado pelas leituras de NDVI, principalmente pela última leitura realizada no estádio fenológico R5 da cultura do milho, antecendo a maturação fisiológica em que se tem acelerado a senescência foliar da cultura. 
Tabela 28. Índice de vegetação por diferença normalizada (NDVI) da cultura do milho em diferentes estádios fenológicos em função de híbridos de milho e da aplicação de diferentes tratamentos fungicidas. Planaltina/DF, 2014.

\begin{tabular}{|c|c|c|c|c|c|c|c|c|}
\hline & \multirow{2}{*}{ Híbrido } & \multicolumn{6}{|c|}{ Fungicida** } & \multirow{2}{*}{ Média } \\
\hline & & 1 & 2 & 3 & 4 & 5 & 6 & \\
\hline \multirow{6}{*}{$\mathrm{V}^{2}$} & DKB 390 & $0.782^{1} \mathrm{aA}^{*}$ & $0.777 \mathrm{aA}$ & $0.782 \mathrm{aA}$ & $0.782 \mathrm{aA}$ & $0.785 \mathrm{aA}$ & $0.787 \mathrm{aA}$ & $0.782 \mathrm{a}$ \\
\hline & P30F53 & $0.770 \mathrm{aA}$ & $0.765 \mathrm{aA}$ & $0.762 \mathrm{aA}$ & $0.767 \mathrm{aA}$ & $0.772 \mathrm{aA}$ & $0.780 \mathrm{aA}$ & $0.769 \mathrm{bc}$ \\
\hline & FÓRMULA & $0.765 \mathrm{aA}$ & $0.770 \mathrm{aA}$ & $0.770 \mathrm{aA}$ & $0.770 \mathrm{aA}$ & $0.762 \mathrm{aA}$ & $0.765 \mathrm{aA}$ & $0.767 \mathrm{c}$ \\
\hline & 2B587 & $0.782 \mathrm{aA}$ & $0.780 \mathrm{aA}$ & $0.780 \mathrm{aA}$ & $0.782 \mathrm{aA}$ & $0.782 \mathrm{aA}$ & $0.780 \mathrm{aA}$ & $0.781 \mathrm{ab}$ \\
\hline & Média & $0.775 \mathrm{~A}$ & $0.773 \mathrm{~A}$ & $0.773 \mathrm{~A}$ & $0.775 \mathrm{~A}$ & $0.775 \mathrm{~A}$ & $0.778 \mathrm{~A}$ & \\
\hline & & \multicolumn{2}{|c|}{ CV $(\%)$ Híbridos } & 1.7 & CV(\%) Fungicidas & 1.63 & Média Geral & 0.775 \\
\hline \multirow{6}{*}{$\mathrm{VT}^{3}$} & DKB 390 & $0.692 \mathrm{aA}$ & $0.695 \mathrm{aA}$ & $0.695 \mathrm{aA}$ & $0.700 \mathrm{aA}$ & $0.690 \mathrm{aA}$ & $0.707 \mathrm{aA}$ & $0.696 \mathrm{a}$ \\
\hline & P30F53 & $0.687 \mathrm{abA}$ & $0.695 \mathrm{aA}$ & $0.685 \mathrm{aA}$ & $0.700 \mathrm{aA}$ & $0.692 \mathrm{aA}$ & $0.700 \mathrm{aA}$ & $0.693 \mathrm{a}$ \\
\hline & FÓRMULA & $0.672 \mathrm{bC}$ & $0.695 \mathrm{aAB}$ & $0.682 \mathrm{aBC}$ & $0.700 \mathrm{aAB}$ & $0.695 \mathrm{aAB}$ & $0.710 \mathrm{aA}$ & $0.692 \mathrm{a}$ \\
\hline & 2B587 & $0.687 \mathrm{abA}$ & $0.702 \mathrm{aA}$ & $0.695 \mathrm{aA}$ & $0.700 \mathrm{aA}$ & $0.697 \mathrm{aA}$ & $0.702 \mathrm{aA}$ & $0.697 \mathrm{a}$ \\
\hline & Média & $0.685 \mathrm{D}$ & $0.696 \mathrm{ABC}$ & $0.689 \mathrm{CD}$ & $0.700 \mathrm{AB}$ & $0.693 \mathrm{BCD}$ & $0.705 \mathrm{~A}$ & \\
\hline & & \multicolumn{2}{|c|}{ CV(\%) Híbridos } & 1.12 & $\mathrm{CV}(\%)$ Fungicidas & 1.37 & Média Geral & 0.695 \\
\hline \multirow{6}{*}{$\mathrm{R} 3^{4}$} & DKB 390 & $0.627 \mathrm{abB}$ & $0.672 \mathrm{aA}$ & $0.665 \mathrm{aA}$ & $0.677 \mathrm{aA}$ & $0.662 \mathrm{abA}$ & $0.687 \mathrm{aA}$ & $0.665 \mathrm{a}$ \\
\hline & P30F53 & $0.605 \mathrm{bC}$ & $0.662 \mathrm{aB}$ & $0.650 \mathrm{abB}$ & $0.677 \mathrm{aAB}$ & $0.667 \mathrm{aB}$ & $0.697 \mathrm{aA}$ & $0.660 \mathrm{a}$ \\
\hline & FÓRMULA & $0.542 \mathrm{cD}$ & $0.672 \mathrm{aA}$ & $0.632 \mathrm{bC}$ & $0.662 \mathrm{aAB}$ & $0.640 \mathrm{bBC}$ & $0.687 \mathrm{aA}$ & $0.639 \mathrm{~b}$ \\
\hline & 2B587 & $0.650 \mathrm{aB}$ & $0.677 \mathrm{aAB}$ & $0.655 \mathrm{abB}$ & $0.667 \mathrm{aAB}$ & $0.667 \mathrm{aAB}$ & $0.695 \mathrm{aA}$ & $0.668 \mathrm{a}$ \\
\hline & Média & $0.606 \mathrm{D}$ & $0.671 \mathrm{~B}$ & $0.650 \mathrm{C}$ & $0.671 \mathrm{~B}$ & $0.659 \mathrm{BC}$ & $0.691 \mathrm{~A}$ & \\
\hline & & \multicolumn{2}{|c|}{ CV $(\%)$ Híbridos } & 2.43 & $\mathrm{CV}(\%)$ Fungicidas & 2.09 & Média Geral & 0.658 \\
\hline \multirow{6}{*}{$\mathrm{R} 5^{5}$} & DKB 390 & $0.545 \mathrm{aC}$ & $0.615 \mathrm{aAB}$ & $0.595 \mathrm{aAB}$ & $0.6125 \mathrm{aAB}$ & $0.580 \mathrm{aBC}$ & $0.627 \mathrm{abA}$ & $0.595 \mathrm{a}$ \\
\hline & P30F53 & $0.507 \mathrm{aB}$ & $0.597 \mathrm{aA}$ & $0.570 \mathrm{abA}$ & $0.607 \mathrm{aA}$ & $0.580 \mathrm{aA}$ & $0.610 \mathrm{bA}$ & $0.578 \mathrm{~b}$ \\
\hline & FÓRMULA & $0.435 \mathrm{bD}$ & $0.605 \mathrm{aB}$ & $0.552 \mathrm{bC}$ & $0.605 \mathrm{aB}$ & $0.572 \mathrm{aBC}$ & $0.662 \mathrm{aA}$ & $0.572 \mathrm{~b}$ \\
\hline & 2B587 & $0.535 \mathrm{aC}$ & $0.610 \mathrm{aAB}$ & $0.577 \mathrm{abBC}$ & $0.622 \mathrm{aAB}$ & $0.597 \mathrm{aAB}$ & $0.640 \mathrm{abA}$ & $0.597 \mathrm{a}$ \\
\hline & \multirow[t]{2}{*}{ Média } & $0.505 \mathrm{D}$ & $0.606 \mathrm{~B}$ & $0.573 \mathrm{C}$ & $0.611 \mathrm{~B}$ & $0.582 \mathrm{C}$ & $0.635 \mathrm{~A}$ & \\
\hline & & \multicolumn{2}{|c|}{ CV(\%) Híbridos } & 3.15 & $\mathrm{CV}(\%)$ Fungicidas & 3.76 & Média Geral & 0.585 \\
\hline
\end{tabular}

1'́ndice de vegetação por diferença normalizada (NDVI); ${ }^{2} \mathrm{~V} 8=$ oito folhas de milho expandidas; ${ }^{3} \mathrm{VT}=$ emissão do pendão; ${ }^{4} \mathrm{R} 3=$ grão pastoso; ${ }^{5} \mathrm{R} 5=$ grão farináceo-duro; *Médias seguidas pela mesma letra, maiúscula na linha e minúscula na coluna, não diferem entre si pelo teste de Tukey (p $\leq 0,05)$. **Fungicidas: 1- Testemunha, 2- Fluxapiroxade + Piraclostrobina + Adjuvante $\left(50,1+99,9\right.$ g i.a. ha $\left.{ }^{-1}+0,5 \% \mathrm{v} / \mathrm{v}\right), 3-$ Benzovindiflupir + Azoxistrobina + Adjuvante $\left(49,5+99 \mathrm{~g}\right.$ i.a. ha $\left.{ }^{-1}+0,5 \% \mathrm{v} / \mathrm{v}\right), 4-$ Bixafen $^{-}$Trifloxistrobina

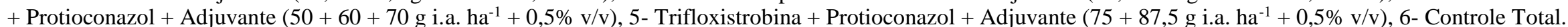


No experimento 2 os gráficos de dispersão de valores de NDVI e AACPD (Figuras 8, 9, 10 e 11) mostraram-se semelhantes aqueles apresentados no experimento 1 (Figuras 3, 4, 5 e 6). A forte correlação obtida entre as leituras de NDVI e AACPD das doenças estudadas podem ser vistas através dos gráficos de dispersão entres os valores destas variáveis (tabelas 29, 30, 31 e 32). Em cada híbrido tem-se uma resposta intrínseca as doenças que nele ocorrem, e a magnitude é de acordo com a tolerância do mesmo a certo patossistema. Com exceção as ferrugens, as demais doenças se repetiram em ambas as épocas e com poucas variações na magnitude com que ocorreram. Os resultados demonstram o potencial de uso do NDVI na avaliação do real estado morfo-fisiológico da cultura principalmente em decorrência da ação de fitopatógenos.

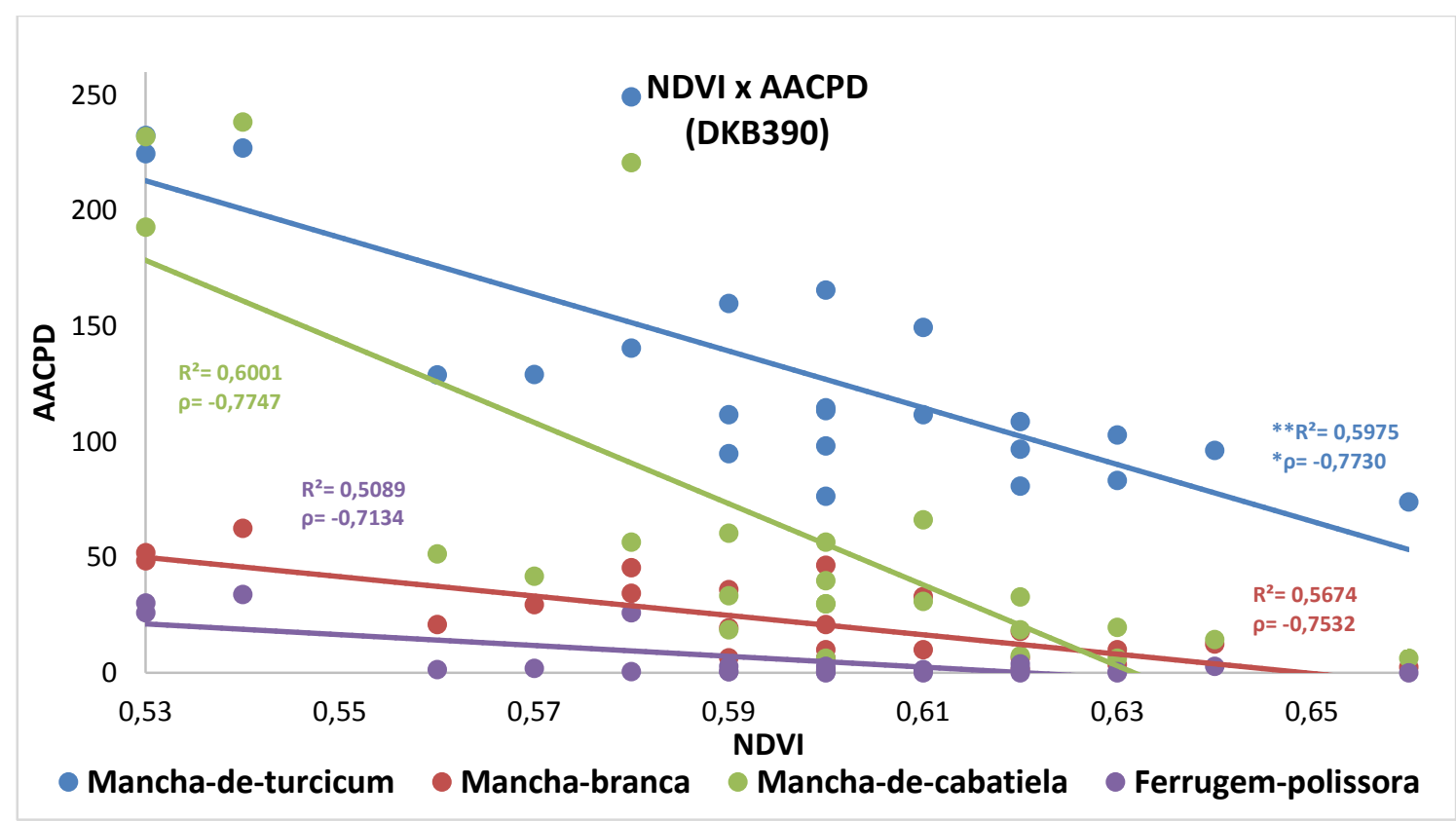

Figura 7. Dispersão entre os valores de Índice de vegetação por diferença normalizada (NDVI) e Ârea abaixo da curva de progresso das doenças (AACPD) mancha-de-turcicum (Exserohilum turcicum), ferrugem-polissora (Puccinia polysora), mancha-de-cabatiela (Kabatiella zeae) e mancha-branca (Phaeosphaeria maydis/Pantoea ananatis) no estádio R5 do híbrido de milho DKB390. *Coeficiente de correlação linear de Pearson; **Fator de determinação. Valores significativos ao nível de $1 \%$ de probabilidade $(\mathrm{p}<0,01)$. 


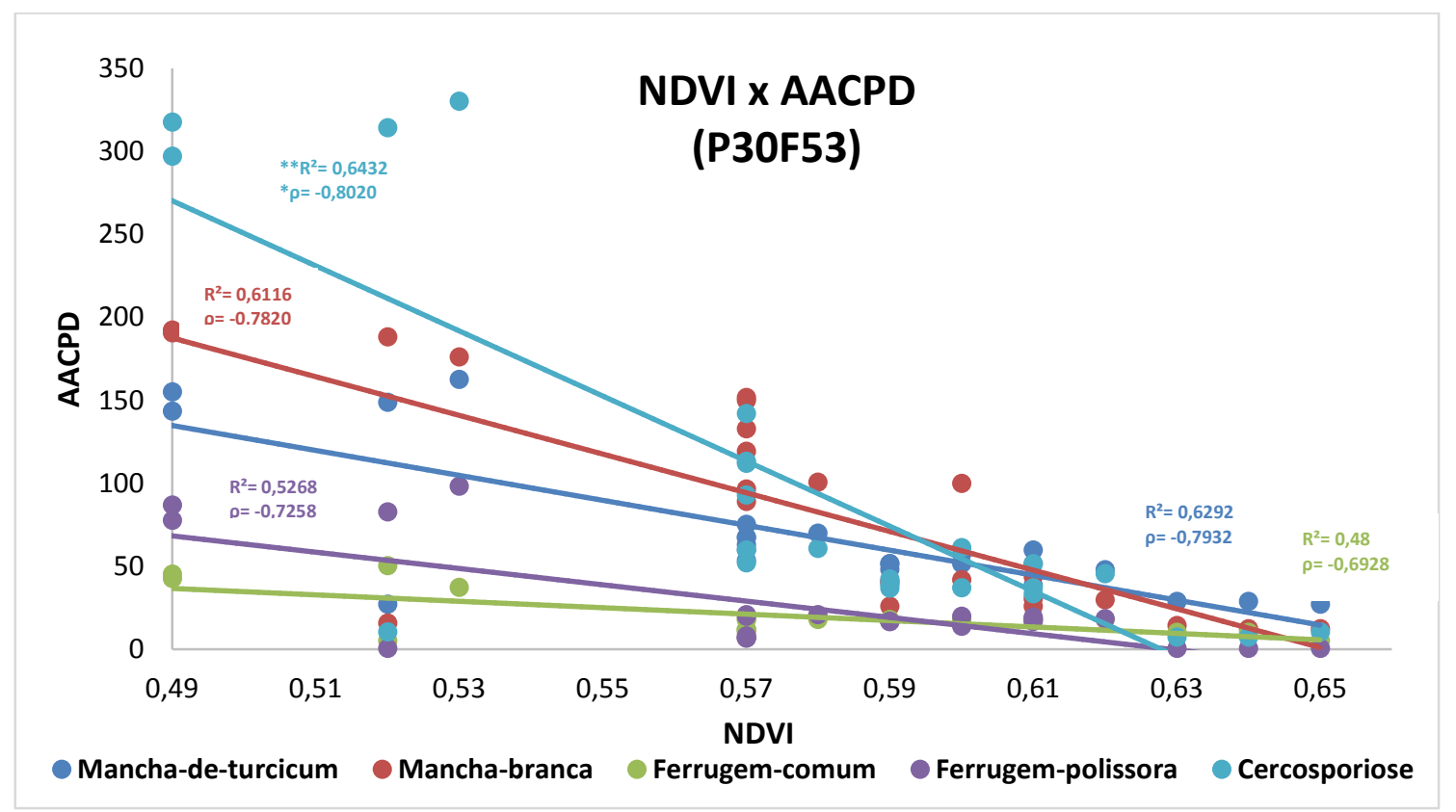

Figura 8. Dispersão entre os valores de Índice de vegetação por diferença normalizada (NDVI) e Ârea abaixo da curva de progresso das doenças (AACPD) mancha-de-turcicum (Exserohilum turcicum), ferrugem-comum (Puccinia sorghi), ferrugem-polissora (Puccinia polysora), mancha-branca (Phaeosphaeria maydis/Pantoea ananatis) e cercosporiose (Cercospora zeaemaydis) no estádio R5 do híbrido de milho P30F53. *Coeficiente de correlação linear de Pearson; **Fator de determinação. Valores significativos ao nível de $1 \%$ de probabilidade $(\mathrm{p}<0,01)$.

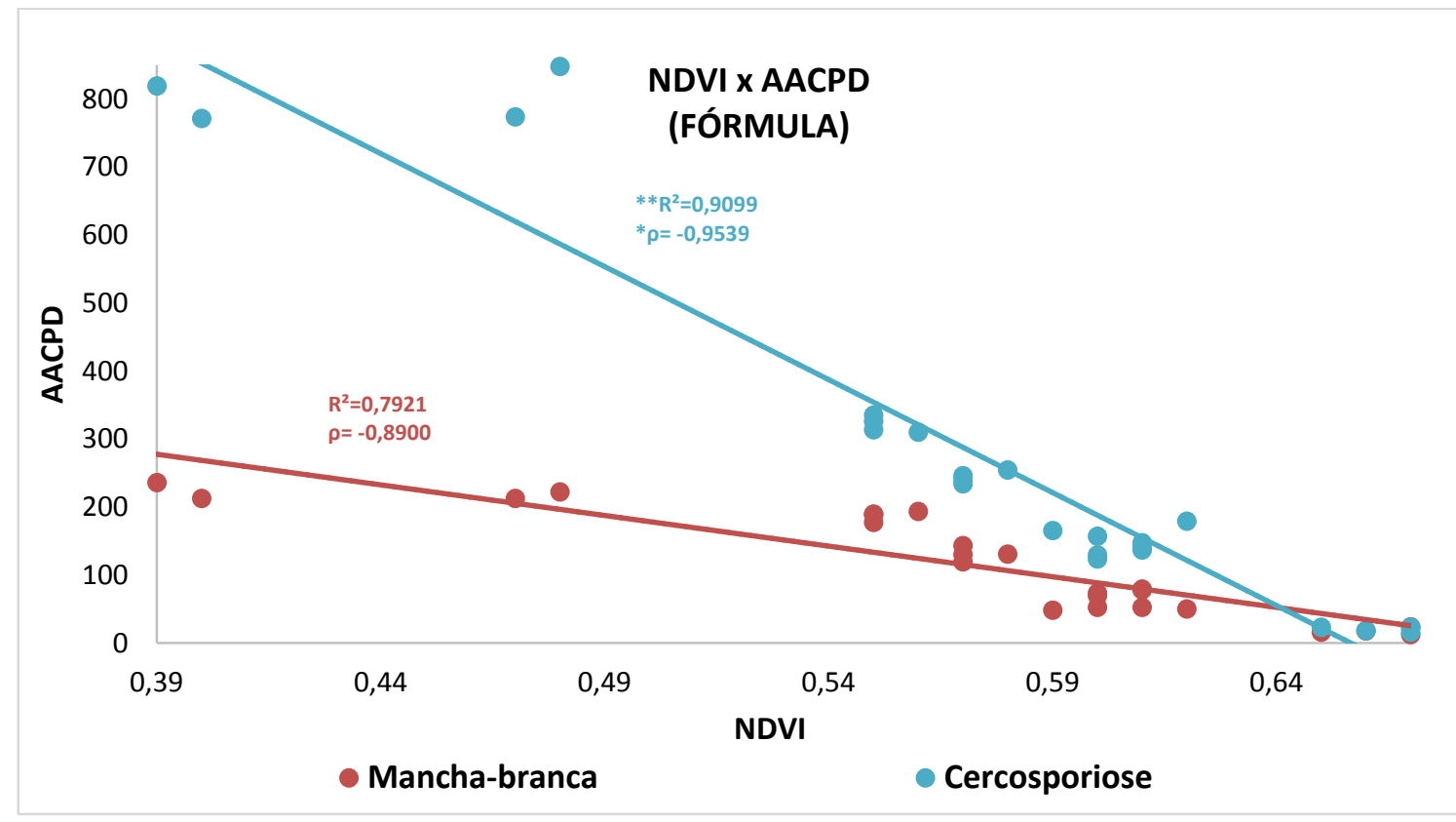

Figura 9. Dispersão entre os valores de Índice de vegetação por diferença normalizada (NDVI) e Área abaixo da curva de progresso das doenças (AACPD) mancha-branca (Phaeosphaeria maydis/Pantoea ananatis) e cercosporiose (Cercospora zeae-maydis) no estádio R5 do híbrido de milho Fórmula. *Coeficiente de correlação linear de Pearson; **Fator de determinação. Valores significativos ao nível de $1 \%$ de probabilidade $(\mathrm{p}<0,01)$. 


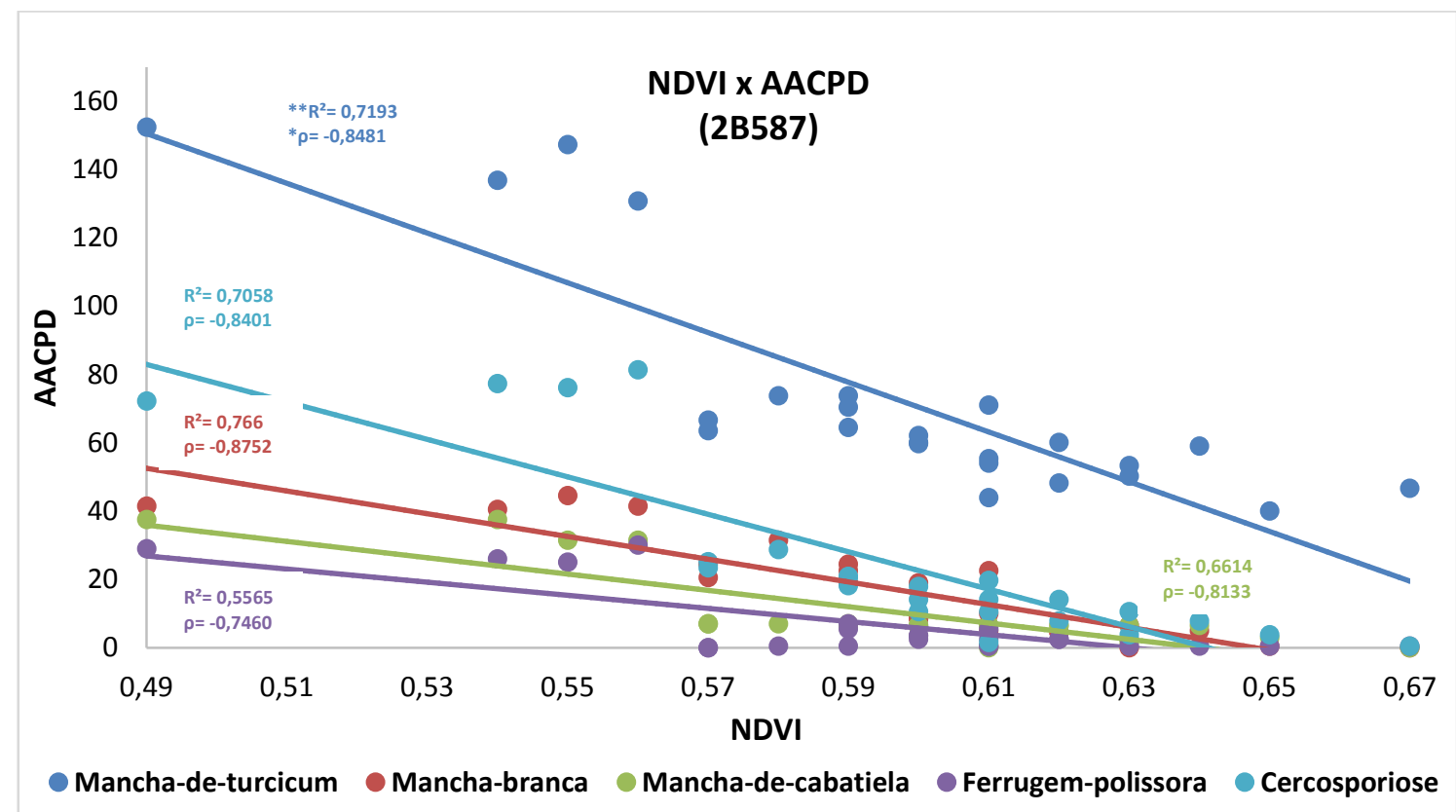

Figura 10. Dispersão entre os valores de Índice de vegetação por diferença normalizada (NDVI) e Área abaixo da curva de progresso das doenças (AACPD) mancha-de-turcicum (Exserohilum turcicum), ferrugem-polissora (Puccinia polysora), mancha-de-cabatiela (Kabatiella zeae), mancha-branca (Phaeosphaeria maydis/Pantoea ananatis) e cercosporiose (Cercospora zeaemaydis) no estádio R5 do híbrido de milho 2B587. *Coeficiente de correlação linear de Pearson; **Fator de determinação. Valores significativos ao nível de $1 \%$ de probabilidade $(\mathrm{p}<0,01)$.

A dispersão entre os valores de NDVI obtidos no estádio R5 da cultura do milho e a produtividade de grãos mostrou-se semelhante a obtida no experimento 1, com exceção ao híbrido 2B587 em que a correlação entre estas variáveis não foi significativa. Shanahan et al. (2001) relataram que as leituras de NDVI em meio ao enchimento de grãos da cultura do milho mostraram ser mais efetivas para se estimar o potencial de rendimento de grãos da cultura do milho. Em concordância as afirmações do autor, é neste período em que se tem melhor ideia do real estado fitossanitário da cultura do milho e assim os reflexos que tal estado pode ter no rendimento final. 


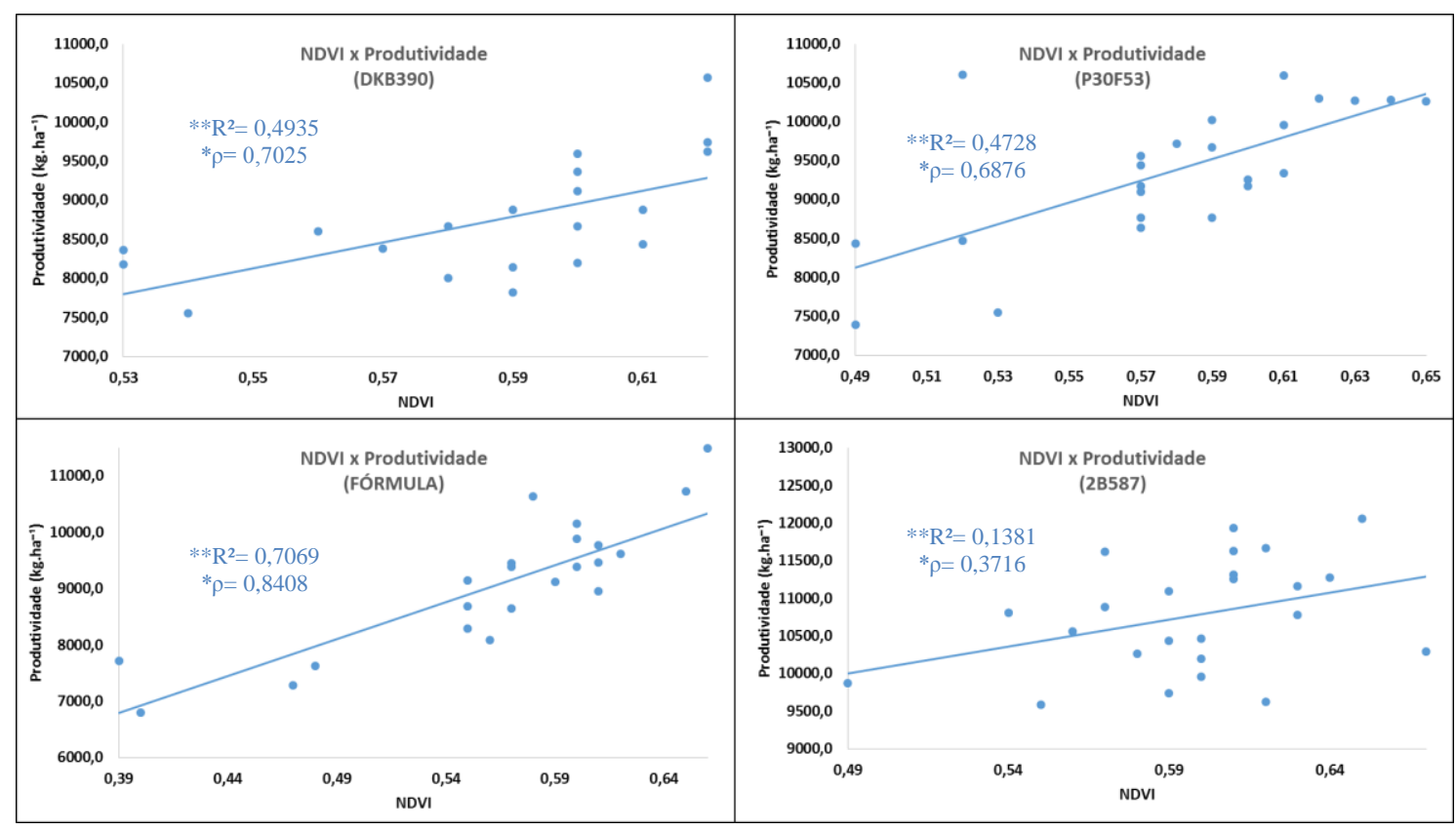

Figura 11. Dispersão entre os valores de NDVI no estádio R5 e produtividade de grãos dos híbridos de milho DKB390, P30F53, FÓRMULA e 2B587. *Coeficiente de correlação linear de Pearson; **Fator de determinação. Valores significativos ao nível de $1 \%$ de probabilidade $(\mathrm{p}<0,01)$.

\subsubsection{Correlação entre as variáveis}

A análise de correlação linear simples entre as variáveis produtividade e massa de mil grãos (MMG), mostrou correlação positiva significativa e forte para os híbridos DKB390, P30F53 e Fórmula (tabelas 29, 30, 31 e 32). Já para 2B587 a correlação não foi significativa, indicando que incrementos nos valores de uma variável não significa necessariamente aumento nos valores da outra variável e vice-versa.

Analisando a correlação entre produtividade AACPD das doenças avaliadas, as correlações foram negativas mas nem todas significativas. As correlações foram mais fortes podem ser visualizadas nos híbridos Fórmula e P30F53. Já em DKB390 e 2B587, as correlações quando significativa foram moderadas, com exceção à AACPD de mancha-branca no DKB390 que apresentou forte correlação negativa. As correlações mais fortes foram entre produtividade e AACPD da mancha-branca, cercosporiose e mancha-de-turcicum no híbrido P30F53 e, mancha-branca e cercosporiose no Fórmula, com valores superiores a $80 \%$ de correlação. No híbrido 2B587 entre as cinco doenças avaliadas, em apenas duas, mancha-branca e mancha-deturcicum a correlação mostrou-se significativa. Percebe-se que as doenças causadas por patógenos necrotróficos foram em ambas as épocas de semeadura, aquelas que mais se relacionam as quedas de produtividade. 
A correlação existente entre o componente de rendimento massa de mil grãos e AACPD, mostrou-se significativa e forte para a maioria das doenças avaliadas. A exceção ocorreu no híbrido 2B587 no qual para as doenças ferrugem-polissora e mancha-de-cabatiela esta correlação foi moderada. Nos híbridos Fórmula e P30F53 a correlação entre MMG e AACPD de todas as doenças foi muito forte, com correlações superando $90 \%$ de linearidade entre as variáveis.

A correlação entre grãos ardidos e AACPD para as diversas doenças, com exceção ao híbrido 2B587, todos os demais apresentaram forte correlação positiva e significativa, indicando que quanto mais doentes as plantas estavam, mais suscetíveis à ocorrência de grãos ardidos estas estão.

Entre AACPD das doenças foliares e Fusarium sp. nos grãos de milho, nos híbridos P30F53, Fórmula e 2B587 as correlações foram positivas significativas de moderadas a fortes e, no DKB390 os valores de correlação, quando significativas, foram em geral moderadas a forte.

Analisando as correlações existentes entre AACPD e NDVI, houve forte correlação negativa significativa entre a AACPD de todos os patossistemas avaliados e a variável NDVI. O mesmo comportamento ocorreu na primeira época de semeadura, indicando que o NDVI pode servir como uma importante informação quanto ao estado sanitário das plantas de milho.

Entre as AACPD das doenças avaliadas a análise de correlação mostrou ser positiva significativa e forte entre todos os patossistemas.

Ao relacionar produtividade e NDVI a análise mostrou que a correlação entre estas variáveis foi positiva significativa e forte nos híbridos DKB390, P30F53 e Fórmula, enquanto que no híbrido 2B587 não foi significativa.

Nos híbridos P30F53 e Fórmula a correlação entre produtividade e grãos ardidos foi negativa significativa e forte. No híbrido DKB390 esta relação foi moderada enquanto que no 2B587 não foi significativa. Para produtividade e incidência de Fusarium sp. nos grãos o comportamento foi exatamente o mesmo que ocorreu com grãos ardidos. O mesmo já havia ocorrido na primeira época de semeadura.

Entre NDVI e MMG a correlação mostrou-se positiva significativa e forte nos híbridos DKB390, P30F53 e Fórmula, enquanto que em 2B587 foi moderada. No híbrido Fórmula esta correlação chegou a $90 \%$. 
A análise de correlação entre NDVI e grãos ardidos, com exceção para o híbrido 2B587 em que não foi significativa, foi negativa significativa e forte para os híbridos DKB390, P30F53 e Fórmula.

Ao correlacionar NDVI com a incidência de Fusarium sp., a análise mostrou que nos híbridos P30F53, Fórmula e 2B587 a correlação existente é negativa significativa e forte entre estas variáveis. Apenas no híbrido DKB390 não foi significativa.

Entre incidência de Fusarium sp. e grãos ardidos a correlação foi significativa apenas nos híbridos P30F53 e Fórmula, onde apresentou-se positiva e forte.

Já a correlação entre MMG e porcentagem de grãos ardidos, esta se mostrou negativa significativa e forte nos híbridos DKB390, P30F53 e Fórmula. No híbrido 2B587 esta correlação não foi significativa.

Tabela 29. Coeficiente de correlação linear de Pearson entre as variáveis produtividade de grãos (Prod.), massa de mil grãos (MMG), área abaixo da curva de progresso das doenças ferrugem-polissora (AACPFp), mancha-de-cabatiela (AACPMc), mancha-branca (AACPMb) e mancha-de-turcicum (AACPMt), incidência de grãos ardidos (\%), incidência de Fusarium verticillidoides em grãos (\%) e índice de vegetação por diferença normalizada (NDVI) no híbrido de milho DKB390. Planaltina/DF, 2014.

\begin{tabular}{|c|c|c|c|c|c|c|c|c|c|}
\hline & Prod. & MMG & G.ardidos & Fusarium & $\mathrm{NDVI}^{1}$ & AACPFp & AACPMC & AACPMb & AACPMt \\
\hline Prod. & 1 & $0.7401 * *$ & $-0.4513 *$ & -0.2782 & $0.7025 * *$ & $-0.4312 *$ & $-0.5465^{* *}$ & $-0.6513 * *$ & $-0.5818 * *$ \\
\hline MMG & & 1 & $-0.6358 * *$ & $-0.6362 * *$ & $0.7682 * *$ & $-0.6158 * *$ & $-0.7585^{* *}$ & $-0.8803 * *$ & $-0.8355^{* *}$ \\
\hline G.ardidos & & & 1 & 0.2172 & $-0.7555^{* *}$ & $0.8898 * *$ & $0.882 * *$ & $0.7535 * *$ & $0.863 * *$ \\
\hline Fusarium & & & & 1 & -0.2951 & 0.2831 & $0.4213^{*}$ & $0.636^{* *}$ & $0.525^{* *}$ \\
\hline $\mathrm{NDVI}^{1}$ & & & & & 1 & $-0.7134 * *$ & $-0.7747 * *$ & $-0.7532 * *$ & $-0.773 * *$ \\
\hline AACPFp & & & & & & 1 & $0.9649 * *$ & $0.7493 * *$ & $0.8665 * *$ \\
\hline AACPMc & & & & & & & 1 & $0.8648 * *$ & $0.9563 * *$ \\
\hline AACPMb & & & & & & & & 1 & $0.9371 * *$ \\
\hline AACPMt & & & & & & & & & 1 \\
\hline
\end{tabular}

**Significativo ao nível de $1 \%$ de probabilidade $(\mathrm{p}<0,01)$; *Significativo ao nível de $5 \%$ de probabilidade $(\mathrm{p} \leq 0,05) ;{ }^{1} \mathrm{NDVI}$ no estádio fenológico de grão farináceo-duro (R5). 
Tabela 30. Coeficiente de correlação linear de Pearson entre as variáveis produtividade de grãos (Prod.), massa de mil grãos (MMG), área abaixo da curva de progresso das doenças cercosporiose (AACPC), ferrugem-comum (AACPFc), ferrugem-polissora (AACPFp), mancha-branca (AACPMb) e mancha-de-turcicum (AACPMt), incidência de grãos ardidos (\%), incidência de Fusarium verticillidoides em grãos (\%) e índice de vegetação por diferença normalizada (NDVI) no híbrido de milho P30F53. Planaltina/DF, 2014.

\begin{tabular}{|c|c|c|c|c|c|c|c|c|c|c|}
\hline & Prod. & MMG & G.ardidos & Fusarium & $\mathrm{NDVI}^{1}$ & AACPC & AACPFC & AACPFp & AACPMb & AACPMt \\
\hline Prod. & 1 & $0.8753 * *$ & $-0.7733 * *$ & $-0.6312 * *$ & $0.6876 * *$ & $-0.8197 * *$ & $-0.7129 * *$ & $-0.7576^{* *}$ & $-0.8304 * *$ & $-0.8464 * *$ \\
\hline MMG & & 1 & $-0.8289 * *$ & $-0.7778 * *$ & $0.768 * *$ & $-0.8915^{* *}$ & $-0.858 * *$ & $-0.8534 * *$ & $-0.8515^{* *}$ & $-0.9237 * *$ \\
\hline G.ardidos & & & 1 & $0.6475^{* *}$ & $-0.6681 * *$ & $0.896 * *$ & $0.7148 * *$ & $0.8025^{* *}$ & $0.8155^{* *}$ & $0.8863^{* *}$ \\
\hline Fusarium & & & & 1 & $-0.6148 * *$ & $0.7942 * *$ & $0.8062 * *$ & $0.8058 * *$ & $0.6464 * *$ & $0.7891 * *$ \\
\hline $\mathrm{NDVI}^{1}$ & & & & & 1 & $-0.802 * *$ & $-0.6928 * *$ & $-0.7258 * *$ & $-0.782 * *$ & $-0.7932 * *$ \\
\hline AACPC & & & & & & 1 & $0.8797 * *$ & $0.9232 * *$ & $0.8915^{* *}$ & $0.973 * *$ \\
\hline AACPFC & & & & & & & 1 & $0.96 * *$ & $0.6882 * *$ & $0.9202 * *$ \\
\hline AACPFp & & & & & & & & 1 & $0.7161 * *$ & $0.9586 * *$ \\
\hline AACPMb & & & & & & & & & 1 & $0.8674 * *$ \\
\hline AACPMt & & & & & & & & & & 1 \\
\hline
\end{tabular}

**Significativo ao nível de $1 \%$ de probabilidade $(\mathrm{p}<0,01)$; *Significativo ao nível de $5 \%$ de probabilidade $(\mathrm{p} \leq 0,05) ;{ }^{1} \mathrm{NDVI}$ no estádio fenológico de grão farináceo-duro (R5).

Tabela 31. Coeficiente de correlação linear de Pearson entre as variáveis produtividade de grãos (Prod.), massa de mil grãos (MMG), área abaixo da curva de progresso das doenças cercosporiose (AACPC) e mancha-branca (AACPMb), incidência de grãos ardidos (\%), incidência de Fusarium verticillidoides em grãos (\%) e índice de vegetação por diferença normalizada (NDVI) no híbrido de milho Fórmula. Planaltina/DF, 2014.

\begin{tabular}{|c|c|c|c|c|c|c|c|}
\hline & Prod. & MMG & G.ardidos & Fusarium & $\mathrm{NDVI}^{1}$ & AACPC & $\mathrm{AACPMb}$ \\
\hline Prod. & 1 & $0.8274 * *$ & $-0.7357 * *$ & $-0.8461 * *$ & $0.8408 * *$ & $-0.836 * *$ & $-0.8125 * *$ \\
\hline MMG & & 1 & $-0.7912 * *$ & $-0.853 * *$ & $0.9006^{* *}$ & $-0.9117 * *$ & $-0.9066 * *$ \\
\hline G.ardidos & & & 1 & $0.8251^{* *}$ & $-0.8385 * *$ & $0.8936^{* *}$ & $0.6894 * *$ \\
\hline Fusarium & & & & 1 & $-0.857 * *$ & $0.9173 * *$ & $0.8328 * *$ \\
\hline $\mathrm{NDVI}^{1}$ & & & & & 1 & $-0.9539 * *$ & $-0.89 * *$ \\
\hline AACPC & & & & & & 1 & $0.8744 * *$ \\
\hline $\mathrm{AACPMb}$ & & & & & & & 1 \\
\hline
\end{tabular}

**Significativo ao nível de $1 \%$ de probabilidade $(\mathrm{p}<0,01)$; *Significativo ao nível de $5 \%$ de probabilidade $(\mathrm{p} \leq 0,05) ;{ }^{1} \mathrm{NDVI}$ no estádio fenológico de grão farináceo-duro (R5). 
Tabela 32. Coeficiente de correlação linear de Pearson entre as variáveis produtividade de grãos (Prod.), massa de mil grãos (MMG), área abaixo da curva de progresso das doenças cercosporiose (AACPC), ferrugem-polissora (AACPFp), mancha-de-cabatiela (AACPMc), mancha-branca (AACPMb) e mancha-de-turcicum (AACPMt), incidência de grãos ardidos (\%), incidência de Fusarium verticillidoides em grãos (\%) e índice de vegetação por diferença normalizada (NDVI) no híbrido de milho 2B587. Planaltina/DF, 2014.

\begin{tabular}{ccccccccccc}
\hline & Prod. & MMG & G.ardidos & Fusarium & \multicolumn{1}{c}{ NDVI $^{1}$} & AACPC & AACPFp & AACPMc & AACPMb & AACPMt \\
\hline Prod. & 1 & 0.3705 & -0.1181 & -0.2365 & 0.3716 & -0.3631 & -0.3495 & -0.3565 & $-0.4259^{*}$ & $-0.4266^{*}$ \\
MMG & 1 & -0.0564 & $-0.4867^{*}$ & $0.5551^{* *}$ & $-0.627^{* *}$ & $-0.501^{*}$ & $-0.5684^{* *}$ & $-0.6748^{* *}$ & $-0.6059^{* *}$ \\
G.ardidos & & & 1 & -0.0206 & -0.2223 & $0.4424^{*}$ & $0.4736^{*}$ & $0.4224^{*}$ & $0.4184^{*}$ & 0.3823 \\
Fusarium & & & & 1 & $-0.6532^{* *}$ & $0.6129^{* *}$ & $0.5462^{* *}$ & $0.6576^{* *}$ & $0.5598^{* *}$ & $0.6232^{* *}$ \\
NDVI $^{1}$ & & & & & 1 & $-0.8401^{* *}$ & $-0.746^{* *}$ & $-0.8133^{* *}$ & $-0.8752^{* *}$ & $-0.8481^{* *}$ \\
AACPC & & & & & 1 & $0.9474^{*}$ & $0.9696^{* *}$ & $0.9165^{* *}$ & $0.9767^{* *}$ \\
AACPFp & & & & & & 1 & $0.9662^{* *}$ & $0.7943^{* *}$ & $0.9503^{* *}$ \\
AACPMc & & & & & & & 1 & $0.8334^{* *}$ & $0.9714^{* *}$ \\
AACPMb & & & & & & & & 1 & $0.8961^{* *}$ \\
AACPMt & & & & & & & & & & 1
\end{tabular}

**Significativo ao nível de $1 \%$ de probabilidade $(\mathrm{p}<0,01)$; *Significativo ao nível de $5 \%$ de probabilidade $(\mathrm{p} \leq 0,05) ;{ }^{1} \mathrm{NDVI}$ no estádio fenológico de grão farináceo-duro (R5). 


\section{CONCLUSÕES}

1. Os fungicidas contendo carboxamidas Fluxapiroxade + Estrobilurina e Bixafen + Estrobilurina + Triazól foram eficazes no controle das doenças cercosporiose (Cercospora zeae-maydis), mancha-branca (Phaeosphaeria maydis/Pantoea ananatis), ferrugem-polissora (Puccinia polysora) e mancha-de-cabatiela (Kabatiella zeae), já o fungicida Benzovindiflupir + Estrobilurina foi eficaz no controle da ferrugem-comum (Puccinia sorghi) e ferrugempolissora (Puccinia polysora).

2. Todos os fungicidas estudados contribuíram para redução da incidência de grãos ardidos e Fusarium verticillioides em grãos de milho.

3. Todos os fungicidas proporcionaram incrementos na produtividade e massa de mil grãos de milho.

4. O uso de NDVI (Índice de Vegetaçaõ por Diferença normalizada) na cultura do milho visando avaliação do estado sanitário em relação a doenças mostrou-se efetivo na diferenciação entre os tratamentos mais doentes e mais sadios.

5. O NDVI mostrou ser um importante parâmetro na estimativa do potencial produtivo da cultura do milho. 


\section{REFERÊNCIAS BIBLIOGRÁFICAS}

ABBOTT, W. S. A method of computing the effectiveness of an insecticide. Journal of Economic Entomology, College Park, v. 18, p.265-267, 1925.

AGRIOS, G. N. Plant pathology. 4th ed. San Diego: Academic Press, 1997. 635 p.

AGRIOS, G. N. Plant pathology. 5a ed. Amsterdam: Elservier, 2004. 922 p.

ANTUNIASSI, U.R; BAIO, F.H.R.; SHARP, T.C. Agricultura de Precisão. In: CONGRESSO BRASILEIRO DO ALGODÃO, 6, 2007, Uberlândia. Anais... Uberlândia: CNPA, 2007. Disponível

em: <http://www.cnpa.embrapa.br/produtos/algodao/publicacoes/cba6/palestras/1622.pdf> Acesso em: 2 de fev. 2015.

ASRAR, G.; MYNENI, R. B.; AND KANEMASU, E. T. (1989), Estimation of plant-canopy attributes from spectral reflectance measurements. In: Theory and Applications of Optical Remote Sensing. G. Asrar, Ed. John Wiley, New York, 1989. 252-296 p.

AZEVEDO, L. A. S. Fungicidas sistêmicos: Teoria e prática. 1.ed. Campinas: EMOPI, 2007. $284 \mathrm{p}$.

BARBOSA, C.A. Manual da Cultura do Milho. Viçosa: AgroJuris, 2010. 199 p.

BERDUGO, C.A. et al. Effect of bixafen on senescence and yield formation of wheat. Pesticide Biochemistry and Physiology, v.104, p.171-177. 2012.

BONALDO, S. M. et al. Avaliação da aplicação de fungicidas em milho, em diferentes estádios fenológicos para o controle da Cercosporiose. In: CONGRESSO NACIONAL DE MILHO E SORGO, 27. 2008. Londrina. Anais....Sete Lagoas: ABMS, 2008. 
BLUM, L.E. B. et al. Desfolha, população de plantas e precocidade do milho afetam a incidência e a severidade de podridões de colmo. Ciência. Rural, Santa Maria, v. 33, n. 5, p. 805-812. Oct. 2003.

BRANDÃO, A.M. Manejo da cercosporiose (Cercosporazeae-maydisTehon\&Daniels) e da ferrugem comum do milho (PucciniasorghiSchw.) pelo uso da resistência genética, fungicidas e épocas de aplicação. 2002. 169f. Dissertação (Mestrado em Agronomia) - Universidade federal de Uberlândia, Uberlândia, MG. 2002.

BRANDÃO, A. M. et al. Fungicidas e épocas de aplicação no controle da ferrugem comum (Puccinia sorghi Schw.) em diferentes híbridos de milho. Bioscience Journal, Uberlândia, v.19, n.1, p.43-52, 2003.

BRASIL (1996) Portaria $n^{\circ}$ 11, de 12 de abril de 1996 Estabelece critérios complementares para classificação do milho. Diário Oficial da União, Brasília, n.72.

BRASIL. Ministério da Agricultura, Pecuária e Abastecimento. Regras para Análise de Sementes. Ministério da Agricultura, Pecuária e Abastecimento. Secretaria de Defesa Agropecuária. Brasília, DF: Mapa/ACS, 2009. 395p.

BRASIL. Instrução Normativa $n^{\circ}$ 60, de 22 de dezembro de 2011. Estabelece o Regulamento Técnico do Milho. Diário Oficial [da República Federativa do Brasil], Brasília, DF, n. 246, 23 dez. 2011. Seção 1, p. 3-5.

BRASIL. Ministério da Agricultura, Pecuária e Abastecimento. Instrução Normativa $\mathrm{N}^{\circ}$ 60, de 22 de dezembro de 2011. Diário Oficial da União, DF, 23 dez. 2011. p. 3, Seção 1.

BRENCHLEY, G.H. Aerial photography for the study of plant diseases. Annual Review of Phytopathology, v. 6, p. 1-23, 1968.

BRITO, A. H. Controle genético e químico de doenças foliares e grãos ardidos em milho. 2010. 89f. Tese (Doutorado em Fitotecnia) - Universidade Federal de Lavras, Lavras, MG. 2010. 
BRITO, A. H. et al. Controle químico de doenças foliares e grãos ardidos em milho (Zea mays L.). Revista Brasileira de Milho e Sorgo, v. 11, n. 1, p. 49-59, 2012.

CALLEGARI-JACQUES, S. M. Bioestatística: princípios e aplicações. Porto Alegre: Artemed, 2003. 90 p.

CARNEIRO, L. C.; BRIGNONI, A.; PEDRIEL, F. C. Efeito de fungicidas no controle da cercosporiose do milho. Fitopatologia Brasileira, Brasília, v. 28, p. S306, 2003. Suplemento.

CASA, R.T. et al. Eficácia do tratamento de sementes de milho com fungicidas comercializadas em Santa Catarina e Rio Grande do Sul na safra de 2003/04. Fitopatologia Brasileira, Fortaleza, 29:209. 2004.

CASA, R. T.; REIS, E. M.; BLUM, M. M. C. Quantificação de danos causados por doenças em milho. In: WORSHOP DE EPIDEMIOLOGIA DE DOENÇAS DE PLANTAS, 1., 2005. Viçosa - MG: Folha de Viçosa Ltda, 2005. p. 43-59.

CAMP, P.J. et al. (1982). Biochemical changes that occur during senescence of wheat leaves: I. basis for the reduction of photosynthesis. Plant Physiology, v. 70, p. 1641-1646, 1982.

CAMPBELL, C.L.; MADDEN, L.V. Introduction to plant disease epidemiology. New York, NY: Wiley. 532p. 1990.

CAMOCHENA, R.C. et al. Avaliação da sensibilidade de genótipos de milho à mancha ocular, causada por Kabatiella zeae. Fitopatologia Brasileira, v. 32, p. 225, 2007.

CAMOCHENA, R.C; SANTOS, I.; MAZARO, S.M. Escala diagramática para avaliação da severidade da Mancha Ocular em milho causada por Kabatiella zeae. Ciência Rural, Santa Maria, v. 38, n. 8, p. 2124-2131, Nov. 2008.

CASELA, C. R.; FERREIRA, A. S.; PINTO, N. F. J. De A. Doenças na Cultura do Milho. Circular 83, Sete Lagoas, MG. Dezembro, 2006. 
CONAB. Acompanhamento da safra brasileira de grãos, v. 2 - Safra 2014/15, n. 6 - Sexto Levantamento, Brasília, p. 1-103, mar. 2015.

COSTA, F. M. Análise da curva de progresso temporal de doenças foliares na cultura do milho Zea Mays L., sob a aplicação da mistura de fungicidas triazóis e estrobirulinas. 2007. 56f. Dissertação (Mestrado em Produção Vegetal) - Universidade Estadual Paulista Julio de Mesquita Filho, Jaboticabal.

COSTA, R. V; COTA, L. V. Controle químico de doenças na cultura do milho: aspectos a serem considerados na tomada de decisão sobre aplicação. Sete Lagoas: Embrapa, 2009. 11p. Circular Técnica, $125 . \quad$ Disponível em: http://www.cnpms.embrapa.br/publicacoes/publica/2009/circular/Circ_125.pdf> Acesso em: 14 mar. 2015.

DAUGHTRY, C. S. T., GALLO, K. P., BAUER, M. E. (1983). Spectral estimates of solar radiation intercepted by corn canopies, Agronomy Journal, v. 75, p. 527-531, 1983.

DAUGHTRY, C.S.T., GALLO, K.P., BIEHL. L.L., KANEMASU, E.T., ASRAR, G., BLAD, B.L., NORMAN, J.M. \& GARDNER, B.R. Spectral estimatives of agronomic characteristics of crops. In: MACHINE PROCESSING OF REMOTE SENSED DATA SYMPOSIUM. 1984. Purddue University, W. Lafayette, IN, 1984.

DAUGHTRY, C.S.T. et al (1992). Spectral estimates of absorbed radiation and phytomass production in corn and soybean canopies. Remote Sensing of Environment, v. 39, p. 141-152, 1992.

DONATO, F.V.; BONALDO, S.M. Avaliação de fungicidas no controle de doenças foliares na cultura do milho no norte de Mato Grosso. Resumos simples. In: CONGRESSO BRASILEIRO DE FITOPATOLOGIA, 2010. Cuiabá- MT.

DUARTE, R. P.et al. Comportamento de diferentes genótipos de milho com aplicação foliar de fungicida quanto à incidência de fungos causadores de grãos ardidos. Bioscience Journal, Uberlândia, v. 25, n. 4, p. 112-122, 2009. 
DUARTE, R. P. et al. Comportamento de diferentes genótipos de milho com aplicação foliar de fungicida quanto à incidência de fungos causadores de grãos ardidos. Bioscience Journal. Uberlândia, v. 25, n. 4, p. 112-122, jul./ago. 2009.

EMBRAPA, 2009. Embrapa Milho e Sorgo. Cultivo do Milho. Sistemas de Produção, 2. ISSN 1679-012X. Versão eletrônica. 2 ed. 2009. Disponível em: <http://www.cnpms.embrapa.br/publicacoes/milho_5_ed/economia.htm>. Acesso em: 15 mar. 2015.

FADER, F.G.; KOLLER, H.R. Realationship between carbon assimilation, portioning and export in leaves of two soybean cultivars. Plant Physiology, Lancaster. v.73, n.2, p.297-303, 1983.

FANCELLI, A.L. Influência do desfolhamento no desempenho de plantas e de sementes de milho (Zea mays L.). 1988. 172p. Tese (Doutorado em Agronomia) - Escola Superior de Agricultura Luiz de Queiroz, Universidade de São Paulo, Piracicaba. 1988.

FANCELLI, A.L.; DOURADO NETO, D. Produção de milho. Guaíba: Agropecuária, 2000. $360 \mathrm{p}$.

FANCELLI, A.L. Cercosporiose de milho: ocorrência e controle. In: FANCELLI, A.L.; DOURADO NETO, D Milho: tecnologia de produção e produtividade. Piracicaba: ESALQ/PV, 2001.

FANCELLI, A.L. Cercosporiose de milho: ocorrência e controle. In: FANCELLI, A.L.; DOURADO NETO, D Milho: tecnologia de produção e produtividade. Piracicaba: ESALQ/PV, 2001.

FANTIN, G. M. et al. Efeito da mancha de phaeosphaeria sobre a produtividade do milho safrinha no Estado de São Paulo. In: CONGRESSO NACIONAL DE MILHO E SORGO, 26., 2006, Belo Horizonte. Anais...Sete Lagoas: ABMS, 2006. 
FANTIN, G. M.; DUARTE, A. P. Manejo de doenças na cultura do milho safrinha. Campinas: Instituto Agronômico, 2009. 99 p.

FEDERER, C.A.; TANNER, C.B. (1966). Spectral distribution of light in the forest. Ecology, v. 47, p. 55-560, 1966.

FERNANDES, F. T.; OLIVEIRA, E. Principais doenças da cultura do milho. Sete Lagoas: Embrapa/CNPMS, 1997. 80p. (Circular Técnica, 26).

FILELLA, I. (1995). Evaluating wheat nitrogen status with canopy reflectance indices and discriminant analysis. Crop Science. v. 35, p. 1400-1405, 1995.

FISCHER, K.S. \& PALMER, F.E. Tropical maize. In: The physiology of tropical field crops. Goldsworthy, P.R. \& Fisher, N.M. Ed. Wiley, 1984. p. 231-248.

FREIRE, F. das C. O.; VIEIRA, I. G. P.; GUEDES, M. I. F.; MENDES, F. N. P. Micotoxinas: Importância na Alimentação e na Saúde Humana e Animal. Documentos 110, Embrapa Agroindústria Tropical (CNPAT), Fortaleza, CE, 48p., out. 2007

FRAC. 2015. Mode of Action of Fungicides. Disponível em: http://www.frac.info/docs/defaultsource/publications/frac-code-list/frac-code-list-2015-finalC2AD7AA36764.pdf?sfvrsn=4. Acesso em: 5 de fev. 2015.

GATES, D.M. et al. (1964). Spectral properties of plants. Applied Optics, v. 4, p. 11-20, 1964.

GLÄTTLI, A., STAMMLER, G., SCHLEHUBER, S. Mutations in the target proteins of succinatedehydrogenase inhibitors (SDHI) and 14 $\alpha$-demethylase inhibitors (DMI) conferring changes in the sensitivity - structural insights from molecular modelling. In: 9TH INTERNATIONAL CONFERENCE ON PLANT DISEASES, Tours, France, 2009. P. 670681.

GODOY, C.V.; HENNING, A.A. Tratamento de semente e aplicação foliar de fungicidas para o controle da ferrugem-da-soja. Pesquisa Agropecuária Brasileira, v.43, p.1297-1302, 2008. 
GROHS, D. S. et al . Modelo para estimativa do potencial produtivo em trigo e cevada por meio do sensor GreenSeeker. Engenharia Agrícola, Jaboticabal , v. 29, n. 1, p.101-112, Mar. 2009.

GROTEN, S.M.E. NDVI-crop monitoring and early yield assessment of Burkina Faso. International Journal of Remote Sensing 14(8), 1495-1515, 1993.

GUICHERIT, E.; BARTLETT, D.; DALE, S. M.; HAAS, H-U.; SCALLIET, G.; WALTER, H. Solatenol - The Second Generation Benzonorbornene SDHI Carboxamide with Outstanding Performance against Key Crop Diseases. In: DEHNE, H. W.; DEISING, H. B.; FRAAIJE, B.; GISI, U.; HERMANN, D.; MEHL, A.; OERKE, E. C.; STAMMLER, G.; KUCK, K. H.; LYR, H. (Eds.) Modern Fungicides and Antifungal Compounds VII. Braunschweig, Germany: Deutsche Phytomedizinische Gesellschaft, 2014. p.67-72.

HARLAPUR, S. I.; KULKARNI, M. S.; SRIKANT KULKARNI PATIL, B. C. Assessment of crop loss due to turcicum leaf blight caused by Exserohilum turcicum (Pass.) Leonard and Suggs in maize. Indian Phytopathology, New Delhi, v. 62, n. 2, p. 144-154, 2009.

HOLBEN, B.N., TUCKER, C.J.; FAN, C.J. Spectral assessment of soybean leaf area and leaf biomass. Photogrammetric Engineering \& Remote Sensing, v. 46, p. 651-656. 1980.

ISAEV, D. Assessment of GreenSeeker® in Peanut Disease Detection. 2012. 47p. Thesis (Degree of Master of Science Biological and Agricultural Engineering) - Faculty of North Carolina State University. Raleigh, North Carolina. 2012.

JARDINE, D. F.; LACA-BUENDÍA, J. P. Eficiência de fungicidas no controle de doenças foliares na cultura do milho. Fazu em Revista, Uberaba, n. 6, p. 11-52, 2009.

JULIATTI, F.C. et al. Controle da feosféria, ferrugem comum e cercosporiose pelo uso da resistência genética, fungicidas e épocas de aplicação na cultura do milho. Bioscience Journal, v. 20, n. 3, p. 45-54, 2004. 
JULIATTI, F. C. et al. Efeito do genótipo de milho e da aplicação foliar de fungicidas na incidência de grãos ardidos. Bioscience Journal, Uberlândia, v. 23, n. 2, p. 34-41, 2007.

KAARS SIJPESTEIJN, A. Mode of action of some traditional fungicides. In: Mode of Action of Antifungal Agents. A. P. J. Trinci and J. F. Ryley, Ed. Cambridge University Press, Cambridge. 1984, p. 135-153.

KEON, J.P.R., WHITE, G.A., HARGREAVES, J.A. (1991): Isolation, characterization and sequence of a gene conferring resistance to the systemic fungicide carboxin from the maize smut pathogen, Ustilago maydis. Current Genetics, v. 19, p. 475-481, 1991.

LAGO, F. L.; NUNES, J. Avaliação da produtividade de milho em relação à aplicação de fungicidas em diferentes estádios. Cultivando o saber, Cascavel, v.1, p. 17-23, 2008.

LAMPARELLI, R.A.C.; ROCHA, J.V. \& BORGHI, E., Geoprocessamento e agricultura de precisão. Guaíba. 2001. 118 p.

LAZAROTO, A.; SANTOS, I.; KONFLANZ, V.; MALAGI, G.; CAMOCHENA, R. C. Escala diagramática para avaliação de severidade da helmintosporiose comum em milho. Ciência Rural, Santa Maria, v. 42, n. 12, p. 2131-2137, 2012.

MA, B.L.; MORRISON, M.J.; DWYER, L.M. (1996). Canopy light reflectance and field greenness to assess nitrogen fertilization and yield of corn. Agronomy Journal, v. 88, p. 915920, 1996.

MA, B.L. et al. Early prediction of soybean yield from canopy reflectance measurements. Agronomy Journal, v.93, n.6, p.1227-1234, 2001. Disponível em: 〈https://www.agronomy.org/publications/aj/abstracts/93/6/1227?access=0\&view=pdf $>$ Acesso em: 10 de fev. 2015.

MATSSON, M.; HEDERSTEDT, L. (2001). The carboxin-binding site on Paracoccus denitrificans succinate: quinone reductase identified by mutations. Journal of Bioenergetics and Biomembranes, v. 33, p. 99-105, 2001. 
MENDES, M. C. Micotoxinas, aspectos químicos e bioquímicos relacionados a grãos ardidos em híbridos de milho. 2009. 106f. Tese (Doutorado em Fitotecnia) - Universidade Federal de Lavras, Lavras. 2009.

MOREIRA, M.A. Noções básicas sobre vegetação e sua interação com a radiação solar. In: Fundamentos do sensoriamento remoto e metodologias de aplicação. 3.ed. São José dos Campos: Editora Universidade Federal de Viçosa, 2007ª . 75-114 p.

NERBASS, F. R. Tratamento de sementes de milho: qualidade comercial, erradicação e transmissão de Fusarium verticillioides. 2008. 79f. Dissertação (Mestrado em Produção vegetal) - Universidade do Estado de Santa Catarina, Lages. 2008.

OLIVEIRA, E. de; FERNANDES, F. T.; CASELA, C. R.; PINTO, N. F. J. de A.; FERREIRA, A. da S. Diagnose e controle de doenças na cultura do milho. In: GALVÃO e MIRANDA. Tecnologias de produção do milho. Viçosa: UFV, 2004. p.227-267.

OSBORNE, S.L. et al. (2002). Use of spectral radiance to estimate in-season biomass and grain yield in nitrogenand water-stressed corn. Crop Science, v. 42, p. 165-171, 2002.

OTTAVIANO, E. CAMUSSI, A. Phenotypic and genetic relationship between yield components in maize. Euphytica, v.30, p.601-609, 1981.

OTTONI, J. R. Análise da incidência de Fusarium spp. toxigênico e de níveis de fumonisinas em grãos ardidos de milho híbrido. 2008. 54p. Dissertação (Mestrado em Microbiologia Agrícola) - Escola Superior de Agricultura Luiz de Queiroz, Universidade de São Paulo, São Paulo. 2008.

PACCOLA-MEIRELLES, L. D. et al. Detection of a bacterium associated with a leaf spot disease of maize in Brazil. Journal of Phytopathology. Berlin, v. 149, p.275-279, 2001.

PAIVA, F.A. e GOULART. A.C.P. Doenças. In: Milho: Informações técnicas. DOURADOS: EMBRAPA-UEPAE. 1991. 198p. 
PATAKY, J.K. Relationships between yield of sweet corn and northern leaf blight caused by Exserohilum turcicum. Phytopathology, v. 82, p. 370-375, 1992.

PEÑUELAS, J.; FILELLA, I. (1998). Visible and near-infrared reflectance techniques for diagnosing plant physiological status. Trends Plant Science, v. 3, p. 151-156, 1998.

PEREIRA, O.A.P.; CARVALHO, R.V.; CAMARGO, L.E.A. Doenças de milho. In: Manual de Fitopatologia. KIMATI, H.; AMORIN, L.; REZENDE, J.A.M.; BERGAMIN FILHO, A. CAMARGO, L.E.A. Ed. São Paulo: Ceres, 2005. v. 2, p. 477-488.

PERKINS, J. M.; PEDERSEN, W. L. Disease development and losses associated with northern leaf blight on corn. Plant Disease, v. 71, p. 940-943, 1987.

PINTO, N.F.J. Tratamento com fungicidas de sementes de milho. In: SOAVE, J., OLIVEIRA, M.R.M.; MENTEN, J.O.M. (Eds.) Tratamento químico de sementes. $4^{\circ}$ SIMPÓSIO BRASILEIRO DE PATOLOGIA DE SEMENTES, Anais...Gramado, RS, 1996. p.52-57.

PINTO, N. F. J. de A. Incidência de grãos ardidos em cultivares de milho precoce. Summa Phytopathologica, Jaguariúna, v. 27, n. 4, p. 433-436, 2001.

PINTO, N. F. J. A. Controle químico de doenças foliares em milho. Revista Brasileira de Milho e Sorgo, Sete Lagoas, v. 3, n. 1, p. 134-138, 2004.

PINTO, N. F. J. de A. Grãos ardidos em milho. Circular Técnica 66, Embrapa Milho e Sorgo (CNPMS), Sete Lagoas, 6p., dez. 2005.

PINTO, N. F. J. de A. Podridão Branca da Espiga de Milho. Comunicado Técnico 141, Embrapa Milho e Sorgo (CNPMS), Sete Lagoas, 6p., dez., 2006.

PINTO, N. F. J. de A. et al. Impacto potencial das mudanças climáticas sobre as doenças do milho no Brasil. In: GHINI, R.; HAMADA, E. Mudanças climáticas: Impactos sobre doenças de plantas no Brasil. Brasília, DF: Embrapa Informação Tecnológica, 2008. 331 p. 
POVH, F.P.; MOLIN, J.P.; GIMENEZ, L.M.; PAULETTI, V.; MOLIN, R.; SALVI, J.V. Comportamento do NDVI obtido por sensor ótico ativo em cereais. Pesquisa Agropecuária Brasileira, v.43, p.1075-1083, 2008.

RAMOS, J.P. Frequência e época de aplicação de fungicidas e seus efeitos em híbridos de milho (Zea mays L.). 2011. 81f. Dissertação (Mestrado em Agronomia) - Universidade Federal de Santa Maria, Santa Maria, RS. 2011.

REIS, E. M.; CASA, R. T. Manual de diagnose e controle de doenças do milho. Lages: Graphel, 1996, $141 \mathrm{p}$.

REIS, E.M.; CASA, R.T. Manual de identificação e controle de doenças do milho. Passo fundo: Aldeia Norte Editora, 1996. 80p.

REIS, E.M.; CASA, R.T.; BRESOLIN, A.C.R. Manual de diagnose e controle de doenças do milho. $2^{\text {a }}$ Ed. Lages: Graphel, 2004. 144 p.

REIS, E. M.; REIS, A. C.; CARMONA, M. A. Manual de fungicidas: guia para o controle químico de doenças de plantas. 6 ${ }^{\mathrm{a}}$ Ed. Passo Fundo: UPF Editora, 2010. 226 p.

RITCHIE, S.W.; HANWAY, J.J. How a corn plant develops. Iowa State University. Special report n. 48, Ames, 1993. Online. Disponível em: www.maize.agron.iastate.edu/ corngrows.html. Acesso em: 15 mar. 2015.

RUDORFF, B.F.T. et al. Resposta espectral do milho e sua relação com altos níveis de produtividade de grãos. In: SIMPÓSIO BRASILEIRO DE SENSORIAMENTO REMOTO, 11, 2003, Belo Horizonte. Anais... Belo Horizonte: INPE: 2003. p.2597-2603.

SANTOS, I. dos. et al. Ocorrência de mancha ocular em milho causada por Kabatiella zeae no Paraná e em Santa Catarina. Fitopatologia Brasileira, v. 32, p. 4, 2007.

SCHIPANSKI, C.A. Manual de identificação e manejo das doenças do milho. Castro: Fundação $\mathrm{ABC}, 2011.137 \mathrm{p}$. 
SEMAR, M.; STROBEL, D.; STRATHMANN, S.; GROEGER, U. Xemium® - the BASF Fungicide Innovation. In: DEHNE, H. W.; DEISING, H. B.; GISI, U.; KUCK, K. H.; RUSSELL, P. E.; LYR, H. (Eds.) Modern Fungicides and Antifungal Compounds VI. Braunschweig, Germany: Deutsche Phytomedizinische Gesellschaft, 2011. p.63-68.

SERRANO, L.; FILELLA, I.; PEÑUELAS, J. (2000). Remote sensing of biomass and yield of winter wheat under different nitrogen supplies. Crop Science, v. 40, p. 723-731, 2000.

SHAH, D. A.; DILLARD, H. R. Managing foliar diseases of processing sweet corn in New York with strobilurin fungicides. Plant Disease, v. 94, p. 213-220, 2010.

SHANAHAN, J.F. et al. (2001). Use of remote-sensing imagery to estimate corn grain yield. Agronomy Journal, v. 93, p. 583-589, 2001.

SHANAHAN J.F. et al. (2003). Use of a crop canopy reflectance sensor to assess corn leaf chlorophyll content. American Society of Animal Science Special Publication, v.66, p.135-150, 2003.

SHURTLEFF, M. C. Compendium of corn diseases. First Edition. The American Phytopathology. 1973. 105 p.

SILVA, F. de A. S. e. \& AZEVEDO, C. A. V. de. Principal Components Analysis in the Software Assistat-Statistical Attendance. In: WORLD CONGRESS ON COMPUTERS IN AGRICULTURE, 7, Reno-NV-USA: American Society of Agricultural and Biological Engineers, 2009.

SILVA, O. C.; SCHIPANSKI, C. A. Manual de identificação e manejo das doenças do milho. $2^{a}$ Ed. Fundação ABC, 2007. 116p.

SOLARI, F. et al. (2008). Active sensor reflectance measurements of corn nitrogen status and yield potential. Agronomy Journal, v. 100, p. 571-579, 2008. 
SUTY-HEINZE, A.; DUNKEL, R.; KRIEG, U.; RIECK, H. Bixafen - The New Cereal Fungicide with Yield Boosting Effects. In: DEHNE, H. W.; DEISING, H. B.; GISI, U.; KUCK, K. H.; RUSSELL, P. E.; LYR, H. (Eds.) Modern Fungicides and Antifungal Compounds VI. Braunschweig, Germany: Deutsche Phytomedizinische Gesellschaft, 2011. p.69-74.

TAIZ, L.; ZEIGER, E. Fotossíntese: as reações luminosas. In: TAIZ, L.; ZEIGER, E. Fisiologia Vegetal. Porto Alegre: Artmed, 2009, p. 147-181.

TEAL, R. K. et al. 2006. In-Season Prediction of Corn Grain Yield Potential Using Normalized Difference Vegetation Index. Agronomy Journal. v.98. n.6. p. 1488-1494. 2006.

TUCKER, C.J., 1979, Red and photographic infrared linear combinations for monitoring vegetation. Remote Sensing of Environment, v.8, n.2, p. 127-150. Maio 1979

UNITED STATES OF AMERICA. United States Department Of Agriculture. World agricultural production. Washington, DC: USDA, 2015. Disponível em: http://www.ntis.gov/products/specialty/usda/fas_a-g.asp . Acesso em: 5 de mar. 2015.

WALLHEAD, M. Foliar Fungicide Effects on Gray Leaf Spot and Yield of Hybrid Corn as Influenced by Application Timing, Hybrid Characteristics and Production Practices. 2012. 73p. Thesis (Plant Pathology) - The Ohio State University.

WALTER, H. New Fungicides and New Modes of Action. In: DEHNE, H. W.; DEISING, H. B.; GISI, U.; KUCK, K. H.; RUSSELL, P. E.; LYR, H. (Eds.) Modern Fungicides and Antifungal Compounds VI. Braunschweig, Germany: Deutsche Phytomedizinische Gesellschaft, 2011. p.47-54.

WARD, J. M. J.; BIRCH, E. B.; NOWELL, D. C. Grey leaf spot on maize. Co-ordinated extension: Maize in Natal, Cedara Agricultural Development Institute, Pietermaritzburg, Republic of South Africa. 1994. 
WEGUlO, S. N.; RIVERA-C, J. M.; MARTINSON, C. A.; NUTTER JUNIOR, F. W.. Efficacy of treatments for control of common rust and northern leaf spot in hybrid corn seed production. Plant Disease, St. Paul, v. 82, n. 5, p. 547-554, 1998.

WIEGAND, C. L. et al. (1990), Multisite analysis of spectralbiophysical data for corn. Remote Sensing of Environment Journal. v. 33, p. 1-16, 1990.

WOLOSHUK, C.; WISE, K. Diseases of corn: Aspergillus ear rot. Purdue University, 3p., 2011.

ZANATTA, P. Controle preventivo de doenças foliares em híbridos comerciais de milho com fungicidas em espaçamento reduzido. 2013. 100f. Dissertação (Mestrado em Produção Vegetal) - Universidade Estadual do Centro-Oeste, Guarapuava, 2013.

ZHAO, D. et al. (2003). Corn (Zea mays L.) growth, leaf pigment concentration, photosynthesis and leaf hyperspectral reflectance properties as affected by nitrogen supply. Plant and Soil, v. 257, p. 205-217, 2003.

ZHAO, D. et al. (2005). Selection of optimum reflectance ratios for estimating leaf nitrogen and chlorophyll concentrations of field-grown cotton. Agronomy Journal, v. 97, p. 89-98, 2005.

ZHAO, D. et al. Canopy reflectance in cotton for growth assessment and lint yield prediction. European Journal of Agronomy, v. 26, n. 3, p. 335-344, 2007. 


\section{ANEXOS}

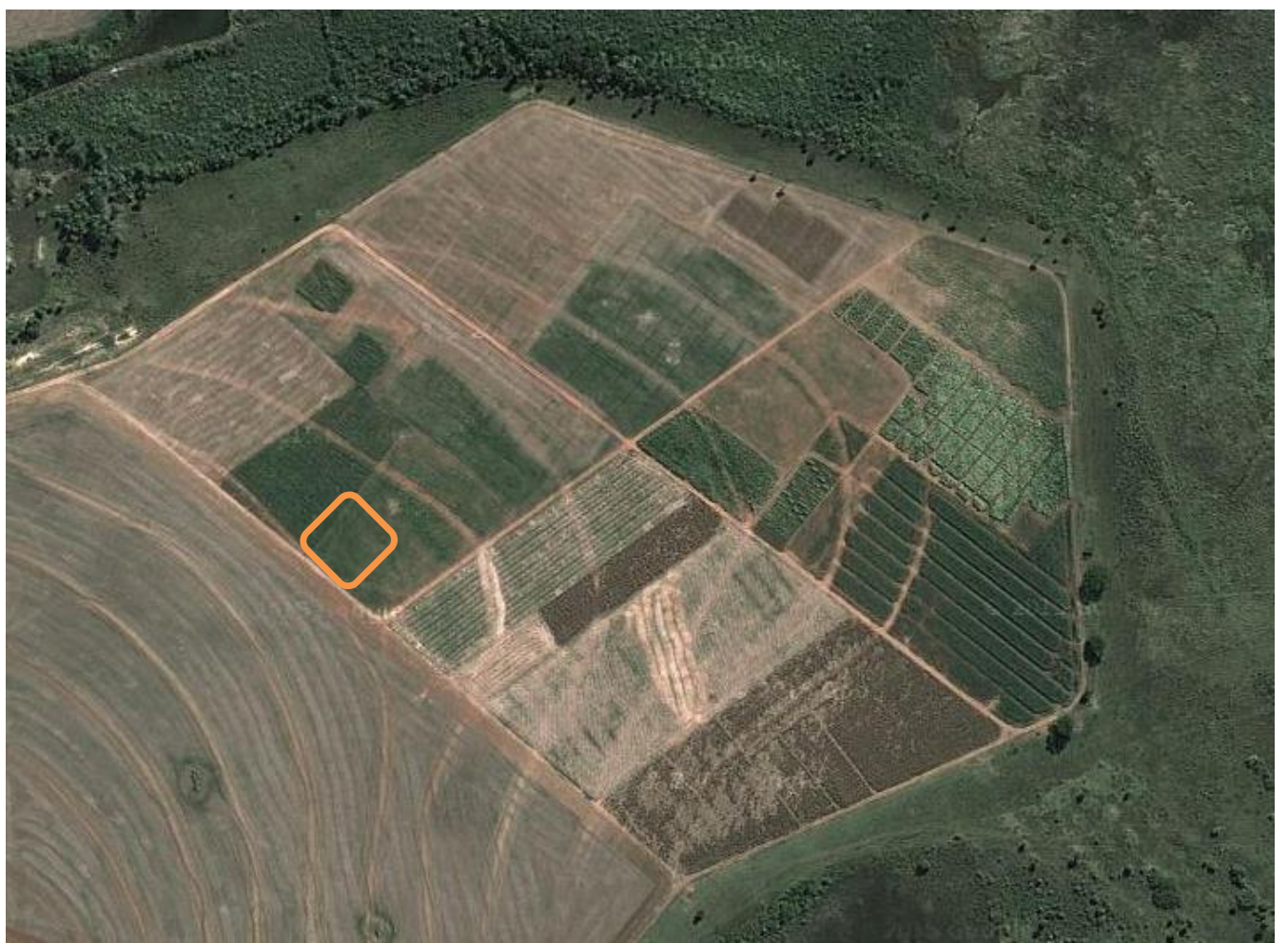

Anexo 1: Localização do ensaio em área experimental do Instituto Phytus, Fazenda Cereal Citrus, Planaltina/DF, 2014. Imagem Google Earth 2014. 


\section{APÊNDICES}

Apêndice 1: Resumo da análise da variância para as variáveis AACPD (área abaixo da curva de progresso da doença) das doenças cercosporiose (AACPC), ferrugem-comum (AACPFc), ferrugem-polissora (AACPFp), mancha-de-cabatiela (AACPMc), mancha-branca (AACPMb) e mancha-de-turcicum (AACPMt), incidência de grãos ardidos, incidência de Fusarium vertillioides em grãos, produtividade e massa de mil grãos (MMG), dos experimentos 1 e 2 . Planaltina/DF, 2014.

\begin{tabular}{|c|c|c|c|c|c|c|c|c|c|c|}
\hline \multirow{2}{*}{ Fonte de variação } & AАCPC & AACPFc & AACPFp & AАCPMc & AACPMb & AACPMt & G. ardidos & Fusarium sp. & Prod. & MMG \\
\hline & \multicolumn{10}{|c|}{ Experimento 1} \\
\hline Híbrido (H) & $* *$ & $* *$ & $* *$ & $* *$ & $* *$ & $* *$ & $* *$ & $* *$ & $* *$ & $* *$ \\
\hline Fungicida (F) & $* *$ & $* *$ & $* *$ & $* *$ & $* *$ & $* *$ & $* *$ & $* *$ & $* *$ & $* *$ \\
\hline$(\mathbf{H}) \times(\mathbf{F})$ & $* *$ & $* *$ & $* *$ & $* *$ & $* *$ & $* *$ & $* *$ & $* *$ & $\mathrm{~ns}$ & $* *$ \\
\hline --------- & \multicolumn{10}{|c|}{ Experimento 2} \\
\hline Híbrido (H) & $* *$ & $* *$ & $* *$ & $* *$ & $* *$ & $* *$ & ns & $* *$ & $* *$ & $* *$ \\
\hline Fungicida (F) & $* *$ & $* *$ & $* *$ & $* *$ & $* *$ & $* *$ & $* *$ & $* *$ & $* *$ & $* *$ \\
\hline$(\mathbf{H}) \times(\mathbf{F})$ & $* *$ & $* *$ & $* *$ & $* *$ & $* *$ & $* *$ & $* *$ & $* *$ & ns & $* *$ \\
\hline
\end{tabular}

**Significativo ao nível de $1 \%$ de probabilidade $(\mathrm{p}<0,01)$; ns = não significativo.

Apêndice 2: Resumo da análise da variância para a variável NDVI nos estádios fenológicos V8, VT, R3 e R5 da cultura do milho, dos experimentos 1 e 2. Planaltina/DF, 2014.

\begin{tabular}{|c|c|c|c|c|}
\hline \multirow{3}{*}{ Fonte de variação } & \multicolumn{4}{|c|}{ NDVI } \\
\hline & V8 & VT & $\mathbf{R 3}$ & $\mathbf{R 5}$ \\
\hline & \multicolumn{4}{|c|}{ Experimento 1} \\
\hline Híbrido (H) & $* *$ & $* *$ & $* *$ & $* *$ \\
\hline Fungicida (F) & $\mathrm{ns}$ & $* *$ & $* *$ & $* *$ \\
\hline$(\mathbf{H}) \times(\mathbf{F})$ & $\mathrm{ns}$ & $\mathrm{ns}$ & $* *$ & $* *$ \\
\hline ---------- & \multicolumn{4}{|c|}{ Experimento 2} \\
\hline Híbrido (H) & $* *$ & $\mathrm{~ns}$ & $* *$ & $* *$ \\
\hline Fungicida (F) & ns & $* *$ & $* *$ & $* *$ \\
\hline$(\mathbf{H}) \times(\mathbf{F})$ & $\mathrm{ns}$ & ns & $* *$ & $* *$ \\
\hline
\end{tabular}

**Significativo ao nível de $1 \%$ de probabilidade $(\mathrm{p}<0,01)$; ns = não significativo. 
Apêndice 3. Valores de significância obtidos da análise de variância para as variáveis produtividade de grãos (Prod.), massa de mil grãos (MMG), área abaixo da curva de progresso das doenças cercosporiose (AACPC), mancha-branca (AACPMb), mancha-de-turcicum (AACPMt), ferrugemcomum (AACPFc), ferrugem-polissora (AACPFp) e mancha-de-cabatiela (AACPMc), e, incidência de grãos ardidos (\%) e incidência de Fusarium verticillidoides em grãos (\%) para diferentes híbridos de milho e tratamentos fungicidas. Planaltina/DF, 2014.

\begin{tabular}{|c|c|c|c|c|c|c|c|c|c|c|}
\hline \multirow{2}{*}{$\begin{array}{l}\text { Fonte de } \\
\text { Variação }\end{array}$} & \multicolumn{10}{|c|}{ Experimento 1} \\
\hline & AACPC $^{1}$ & AACPMb & AACPMt & AACPFC & AACPFp & AACPMc & Grãos ardidos ${ }^{2}$ & F. verticillioides ${ }^{3}$ & Prod. & MMG \\
\hline Blocos & ns* & ns & ns & ns & ns & ns & ns & ns & ns & ns \\
\hline Híbridos (H) & $1903,6209^{* *}$ & 656,7759 & 4541,4591 & 241,2805 & 8494,8777 & 2669,7792 & 25,1957 & 178,3339 & 56,6691 & 2311,1753 \\
\hline Fungicidas (F) & 813,6764 & 1178,7176 & 330,6886 & 562,5847 & 185,9853 & 349,2183 & 44,3484 & 52,2928 & 21,1995 & 600,3146 \\
\hline$(H) \times(F)$ & 166,0908 & 50,4127 & 51,3272 & 16,7285 & 185,9853 & 118,1382 & 3,649 & 10,4702 & ns & 20,7393 \\
\hline -------------- & \multicolumn{10}{|c|}{ Experimento 2} \\
\hline Blocos & ns & 7,6197 & ns & ns & ns & ns & ns & ns & ns & ns \\
\hline Híbridos (H) & 10141,9006 & 1945,6621 & 5935,4898 & 7132,7505 & 794,0727 & 7830,6809 & ns & 75,4871 & 38,4697 & 472,0207 \\
\hline Fungicidas (F) & 1640,2075 & 1556,7667 & 472,5149 & 83,3505 & 731,2025 & 336,8121 & 51,576 & 38,548 & 20,5574 & 138,3284 \\
\hline (H) $x(F)$ & 327,501 & 55,4095 & 58,6532 & 83,3505 & 111,9569 & 163,4895 & 3,5023 & 5,07 & ns & 11,3321 \\
\hline
\end{tabular}

*Não significativo; **Significativo ao nível de $1 \%$ de probabilidade (p<0,01); ${ }^{1}$ Para efeito de análise os dados de AACPD foram transformados em $\sqrt{x+5}$; ${ }^{2}$ Dados de incidência de grãos ardidos transformados em $\log (\mathrm{x}+1) ;{ }^{3}$ Dados de incidência de Fusarium verticillioides foram transformados em arcsen $\sqrt{x / 100}$. 
Apêndice 4. Valores de significância obtidos da análise de variância para a variável NDVI (Índice de vegetação por diferença normalizada) diferentes híbridos de milho e tratamentos fungicidas. Planaltina/DF, 2014.

\begin{tabular}{ccccc}
\hline \multirow{2}{*}{ Fonte de Variação } & \multicolumn{5}{c}{ 1a Época } \\
\cline { 2 - 5 } & V8 & VT & R3 & R5 \\
\hline Blocos & $\mathrm{ns}$ & $\mathrm{ns}$ & $\mathrm{ns}$ & $\mathrm{ns}$ \\
Híbridos (H) & 40,4639 & 13,958 & 366,05 & 300,1756 \\
Fungicidas (F) & $\mathrm{ns}$ & 4,0576 & 23,984 & 76,1099 \\
(H) $\mathbf{x}$ (F) & $\mathrm{ns}$ & $\mathrm{ns}$ & 4,8571 & 14,9054 \\
\hline----- & & & 2a Época & \\
\hline Blocos & $\mathrm{ns}$ & $\mathrm{ns}$ & $\mathrm{ns}$ & $\mathrm{ns}$ \\
Híbridos (H) & 8,8727 & $\mathrm{~ns}$ & 16,0512 & 10,9612 \\
Fungicidas (F) & $\mathrm{ns}$ & 9,2202 & 71,6659 & 66,819 \\
(H) $\mathbf{x}$ (F) & $\mathrm{ns}$ & $\mathrm{ns}$ & 6,7633 & 4,2266 \\
\hline
\end{tabular}

*Não significativo; $* *$ Significativo ao nível de $1 \%$ de probabilidade $(\mathrm{p}<0,01)$; 


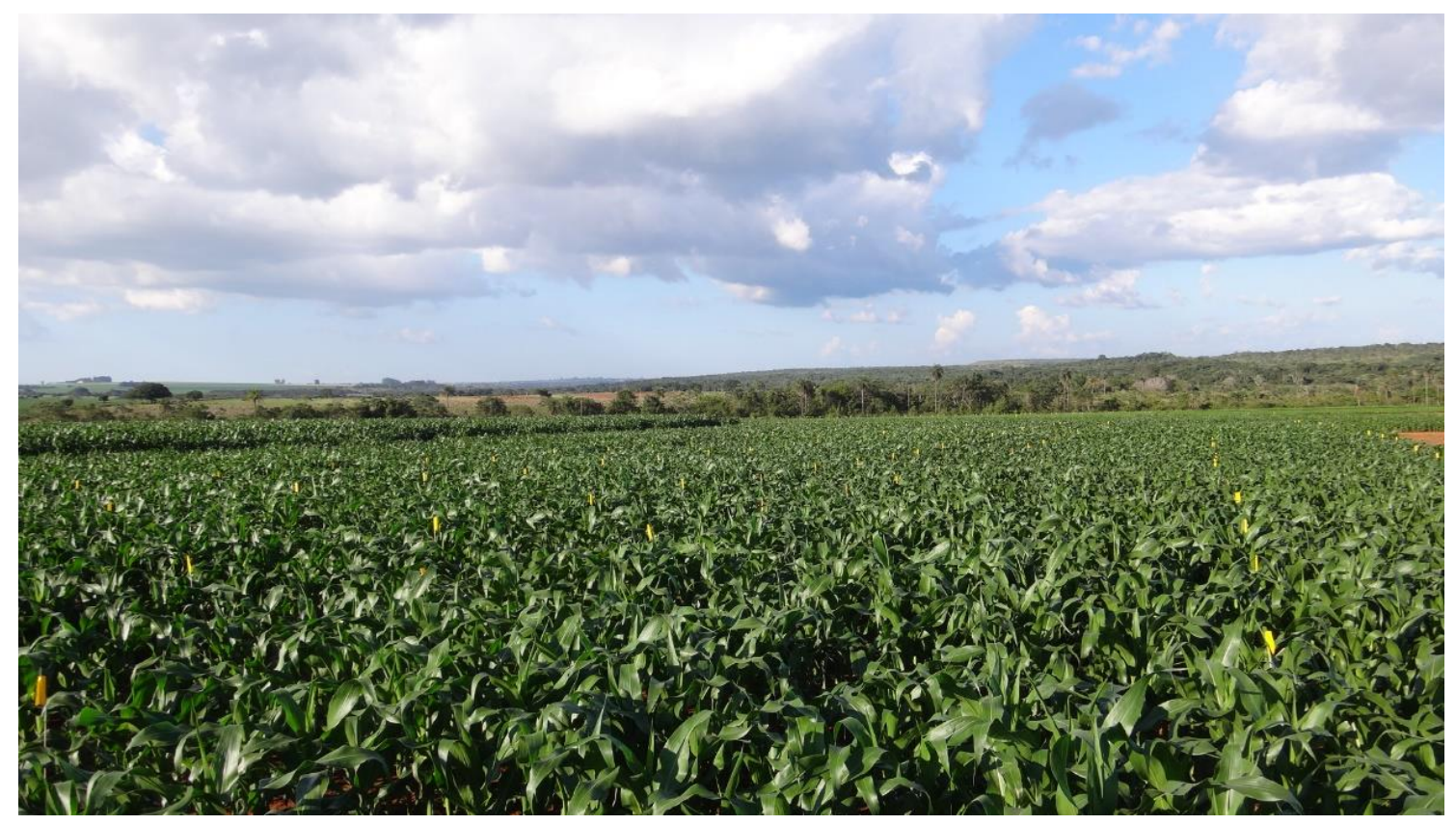

Apêndice 5: Vista geral dos experimentos em área experimental do Instituto Phytus, Fazenda Cereal Citrus, Planaltina/DF, 2014. 


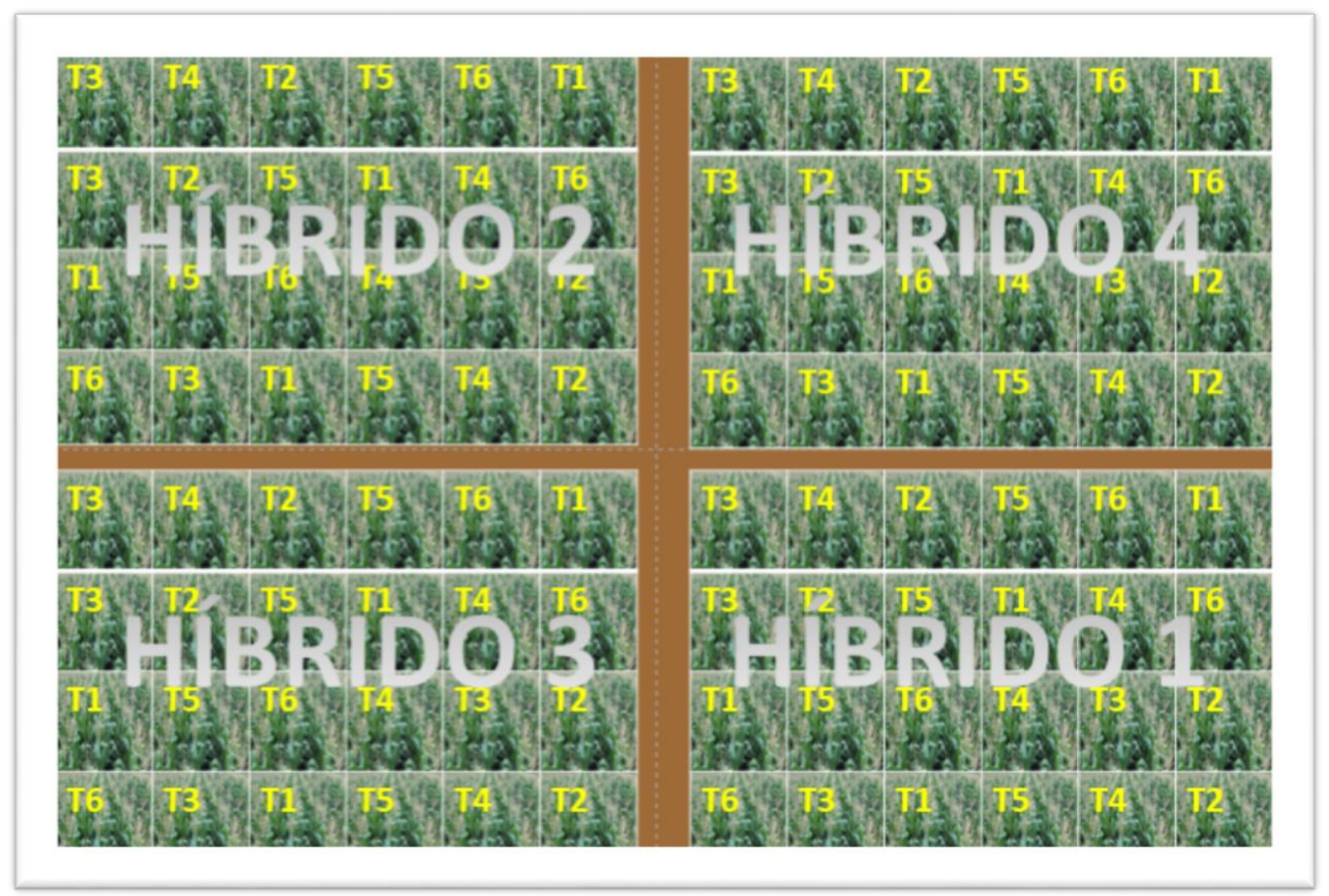

Apêndice 6: Croqui dos experimentos 1 e 2 em área experimental do Instituto Phytus, Fazenda Cereal Citrus, Planaltina/DF, 2014. 


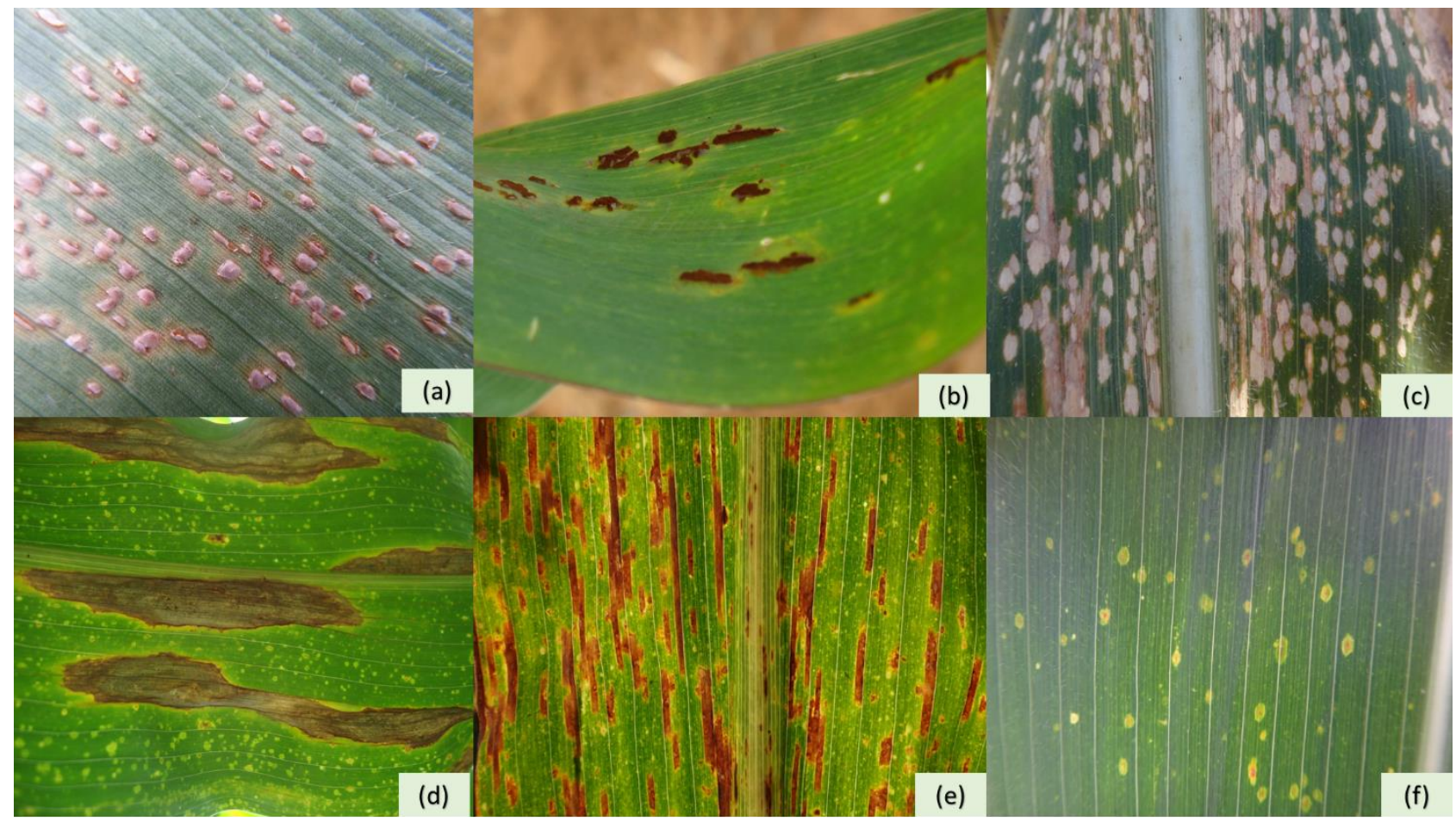

Apêndice 7. Doenças avaliadas nos experimentos 1 e 2 em diferentes híbridos de milho. (a) ferrugem-polissora (Puccinia polysora); (b) ferrugem-comum (Puccinia sorghi); (c) manchabranca (Phaeosphaeria maydis/Pantoea ananatis); (d) Exserohilum turcicum; (e) cercosporiose (Cercospora zeae-maydis); (f) mancha-de-cabatiela (Kabatiella zeae). Planaltina/DF, 2014.

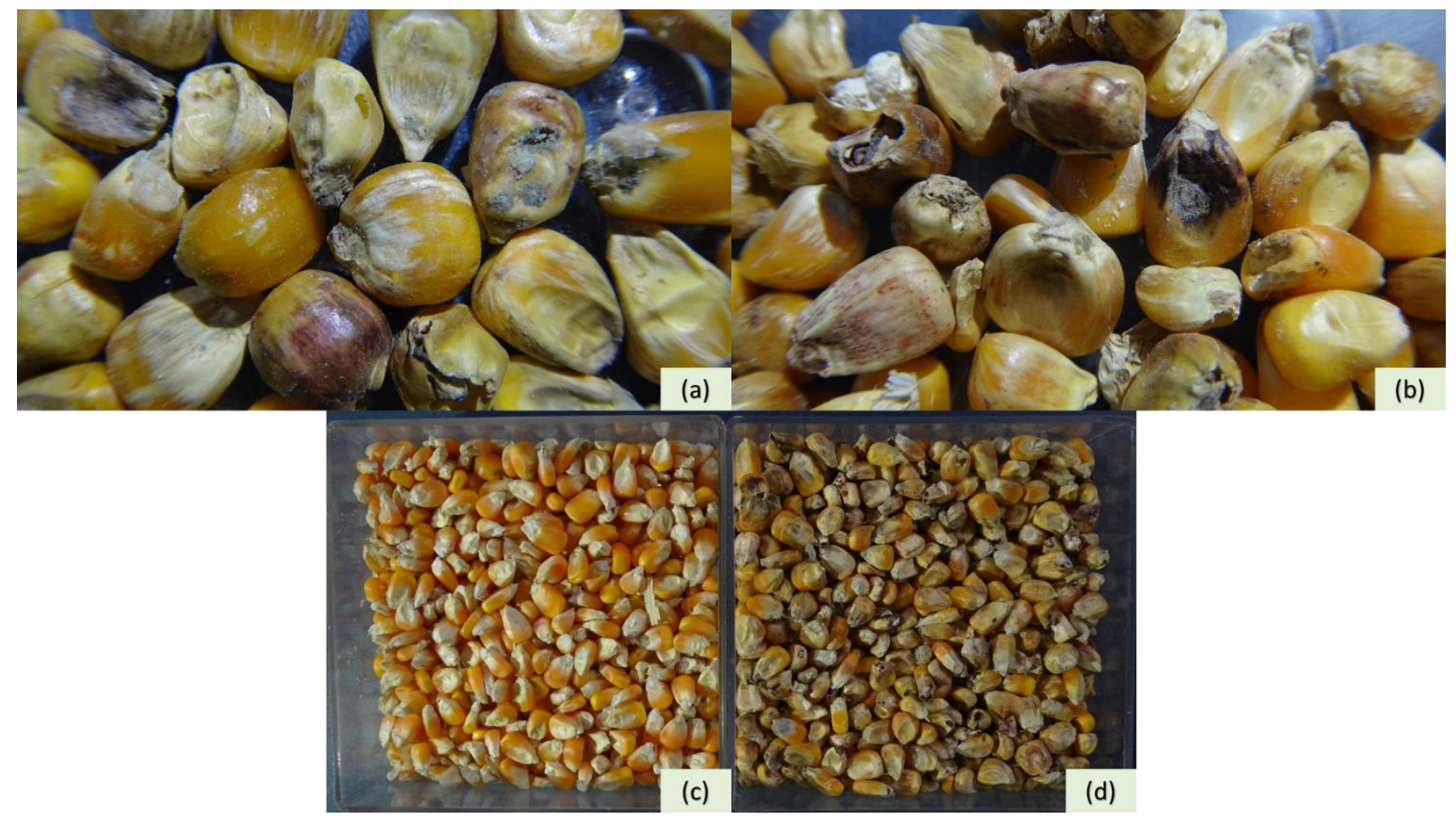

Apêndice 8. Fusarium verticillioides em grãos de milho (a) e (b), e, grãos ardidos (d) e sadios (c) em diferentes híbridos de milho. Planaltina/DF, 2014. 


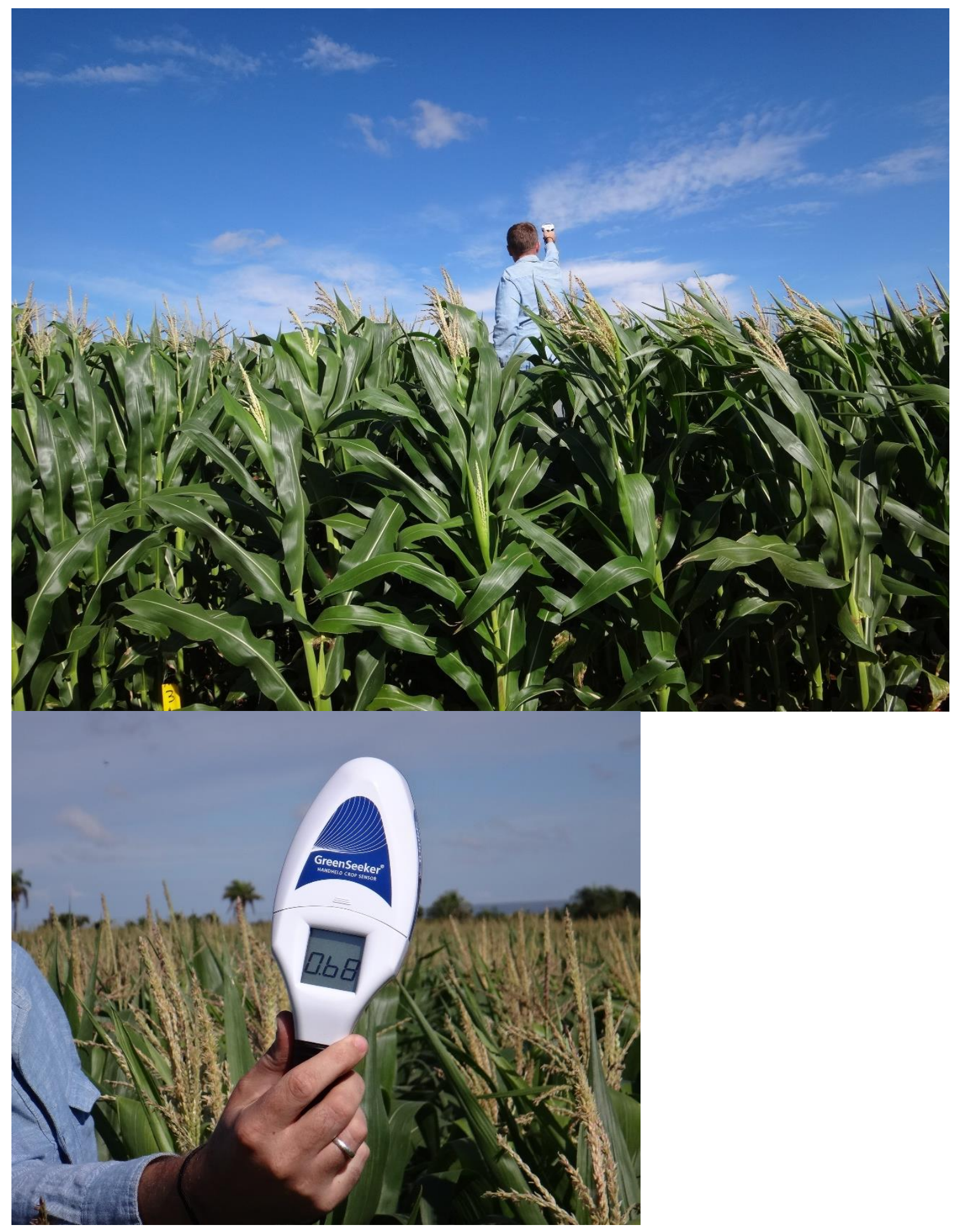

Apêndice 9. Sensor GreenSeeker® utilizado para as leituras de NDVI (Índice de vegetação por diferença normalizada) na cultura do milho. Planaltina/DF, 2014. 